


\title{
Convention on Biological Diversity
} Sixth National Report of the Kingdom of the Netherlands

\author{
M.E. Sanders \\ R.J.H.G. Henkens \\ D.M.E. Slijkerman
}

Project WOT-04-009-033

Statutory Research Tasks Unit for Nature \& the Environment

Wageningen, May 2019

WOt-technical report 156

ISSN 2352-2739

DOI: https://doi.org/10.18174/499170 


\section{Abstract}

Sanders, M.E., R.J.H.G. Henkens \& D.M.E. Slijkerman (2019). Convention on Biological Diversity; Sixth National Report of the Kingdom of the Netherlands. Wageningen, the Statutory Research Tasks Unit for Nature \& the Environment (WOT Natuur \& Milieu). WOt-technical report 156. 136 p.; 48 Figs; 4 Tabs; 234 Refs. 3 Annexes.

The Netherlands is one of the most densely populated countries in the world. Most of the country's land area is highly productive agricultural land. There is little or no area of natural ecosystem that could be called pristine, although high biodiversity values are certainly found. The Kingdom of the Netherlands also comprises six Caribbean islands with, among other things, tropical rainforests, mangrove forests and coral reefs. The main cause of the long-term decline biodiversity has been the intensification of agricultural production, including the reclamation of semi-natural areas, the drainage of wet areas, the use of artificial fertilizer, etc. But also unsustainable fishing, pollution, overgrazing, climate change and invasive alien species cause a decline in biodiversity. To reverse this decline, the Netherlands has prepared and implemented action plans and targets for biodiversity since 1990. This report presents the most important efforts to achieve the biodiversity targets.

Key words: Biodiversity, ecosystem services, natural capital, Aichi biodiversity targets, national ecological network, programmatic approach to nitrogen

\section{Referaat}

Sanders, M.E., R.J.H.G. Henkens \& D.M.E. Slijkerman (2019). Verdrag inzake biologische diversiteit; Zesde nationaal rapport van het Koninkrijk der Nederlanden. Wettelijke Onderzoekstaken Natuur \& Milieu, WOttechnical report 156. 136 blz.; 48 fig.; 4 tab.; 243 ref; 3 Bijlagen.

Nederland is een van de dichtstbevolkte landen ter wereld. Het grootste deel van het landoppervlak van het land is zeer productieve landbouwgrond. Er is weinig of geen gebied dat ongerept kan worden genoemd, hoewel hoge biodiversiteitswaarden zeker worden gevonden. Het Koninkrijk der Nederlanden omvat ook zes Caribische eilanden met onder andere tropisch nevelbossen, mangrovebossen en koraalriffen. De belangrijkste oorzaak van de langdurige achteruitgang van biodiversiteit was de intensivering van de landbouwproductie, inclusief de ontginningen van semi-natuurlijke gebieden, het ontwateren van natte gebieden, het gebruik van kunstmest, enz. Maar ook niet-duurzame visserij, vervuiling, overbegrazing, klimaatverandering en invasieve exoten veroorzaken een achteruitgang van biodiversiteit. Om deze achteruitgang om te keren, heeft Nederland sinds 1990 verschillende plannen en doelen voor biodiversiteit opgesteld en geïmplementeerd. Deze rapportage presenteert de belangrijkste inspanningen om de biodiversiteitsdoelen te bereiken

Trefwoorden: Biodiversiteit, ecosysteemdiensten, natuurlijk kapitaal, CBD, biodiversiteitsdoelen, Aichi-targets, Natuurnetwerk Nederland (NNN), Programma Aanpak Stikstof (PAS)

Cover photo: Diana Slijkerman/Frank Albertsma Photos: Marlies Sanders, Diana Slijkerman/Frank Albertsma, Ruut Wegman

\section{(C) 2019 Wageningen Environmental Research PO Box 47, 6700 AA Wageningen Phone: +31317 480 700; e-mail: marlies.sanders@wur.nl rene.henkens@wur.nl}

\author{
Wageningen Marine Research \\ PO Box 57, 1780 AB Den Helder \\ Phone: +31317480 900; \\ e-mail: diana.slijkerman@wur.nl
}

The WOt-technical reports series is published by the Statutory Research Tasks Unit for Nature \& the Environment (WOT Natuur \& Milieu), part of Wageningen University \& Research. This document is available from the secretary's office, and can be downloaded from www.wur.nl/wotnatuurenmilieu

CC BY-NC Statutory Research Tasks Unit for Nature \& the Environment, P.O. Box 47, NL-6700 AA Wageningen, The Netherlands.

Phone: +31317 4854 71;

e-mail: info.wnm@wur.nl;

Internet: www.wur.nl/wotnatuurenmilieu 


\section{Woord vooraf}

De ongekend snelle achteruitgang van de biodiversiteit vormt een minstens even grote bedreiging voor de mensheid als de opwarming van de aarde, zo stelt IPBES (The International Science-Policy Platform on Biodiversity and Ecosystem Services) in haar rapport 'First Global Assessment Report on Biodiversity and Ecosystem Services'. Biodiversiteit (een samenvoeging van 'biologisch' en 'diversiteit') is een samenvattend begrip voor de totale rijkdom aan leven op aarde van het niveau van genen en plantenen diersoorten tot aan complete ecosystemen. Biodiversiteit gaat op wereldniveau hard achteruit als gevolg van destructief landgebruik, klimaatverandering, overbevissing, vervuiling en invasieve soorten. Zonder ingrijpende maatregelen zullen tussen de 500.000 en een miljoen planten- en diersoorten de komende decennia uitsterven. Dit terwijl biodiversiteit, en natuur in brede zin, talloze diensten en producten leveren aan maatschappij en economie en als zodanig onmisbaar zijn voor het menselijk bestaan op aarde. Het IPBES-rapport is een wetenschappelijke analyse van de toestand van de natuur en biodiversiteit op wereldniveau en is de wetenschappelijke basis voor een nieuw biodiversiteitsverdrag dat in 2020 moet worden afgesloten door de 132 lidstaten en partijen van de VN-Conventie over Biodiversiteit (CBD) uit 1992, de tegenhanger van het VN-klimaatverdrag uit datzelfde jaar.

Is de achteruitgang van biodiversiteit ook zo groot in Nederland? Wat doet Nederland om het biodiversiteitsverlies te stoppen en hoe effectief is dat? Naast het IPBES-rapport van de Verenigde Naties hebben de partijen ook zelf een rapportage van de toestand van de natuur en biodiversiteit op nationaal niveau opgesteld voor de CBD. Het ministerie van Landbouw, Natuur en Voedselkwaliteit heeft deze rapportage daarnaast op 12 juli 2019 ook naar de Tweede Kamer gestuurd. De tekst van deze nationale rapportage, samengesteld door Wageningen Environmental Research, heeft in dit WOttechnical report een beter leesbare indeling en een aantrekkelijke opmaak gekregen.

Marlies Sanders

René Henkens

Diana Slijkerman 


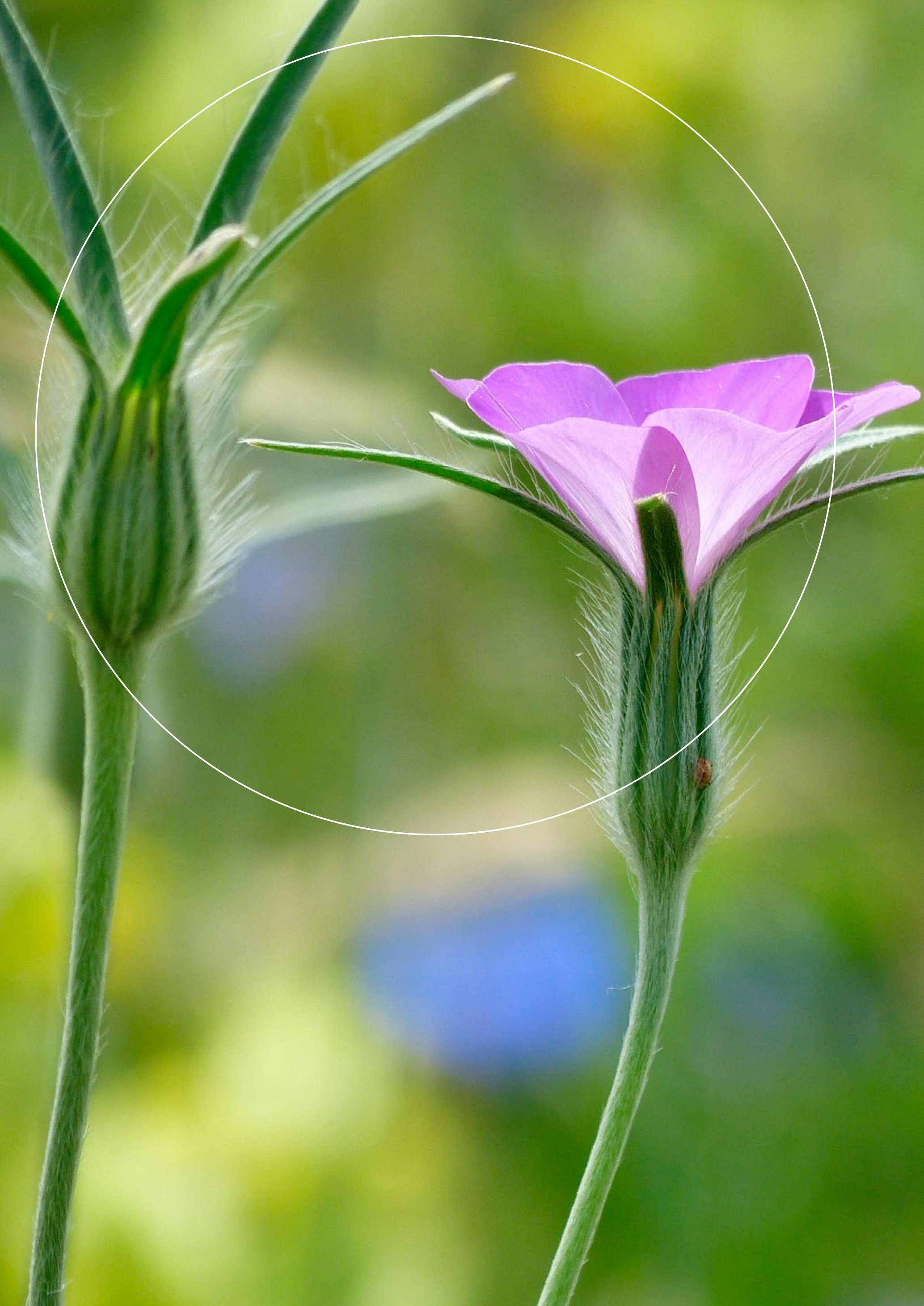




\section{Contents}

$\begin{array}{ll}\text { Samenvatting } & 7\end{array}$

Executive Summary $\quad 11$

$\begin{array}{ll}\text { Introduction } & 19\end{array}$

I National Targets $\quad 21$

II Main Measures $\quad 29$

III Assessment of Main Measures 33

IV Assessment of National Targets 47

$\begin{array}{lll}\text { V Aichi Biodiversity Targets } & 61\end{array}$

VI Sustainable Development Goals $\quad 119$

$\begin{array}{ll}\text { VII Country Profile } & 121\end{array}$

$\begin{array}{ll}\text { Justification } & 125\end{array}$

$\begin{array}{ll}\text { Appendices } & 126\end{array}$ 

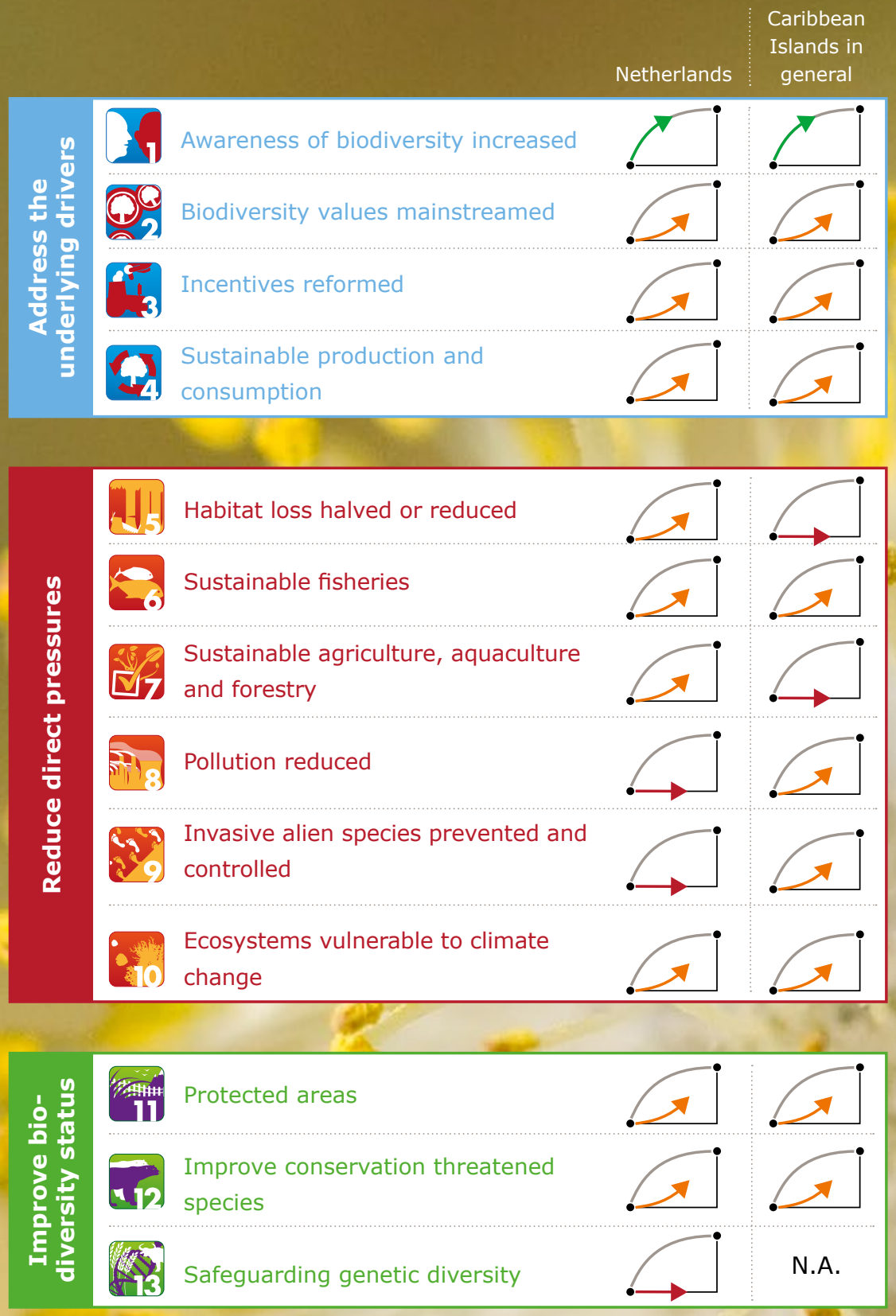

\section{Estimated effectiveness of main measures}

habitats affected by agriculture and forestry

Sustainable fisheries

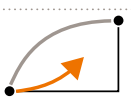

Invasive alien species controlled,

eradicated, prevented

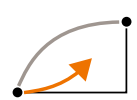

Contribution to avert global

biodiversity loss.

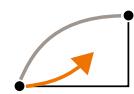

National ecological network (NEN)

t

The Nature Conservation Act

$\pm$

Subsidies for management measures

t

Programmatic Approach to Nitrogen

(PAN)

+1

Stimulating sustainable use of natural capital

+

Utilising the self-organising capacities of society

+

\section{Ecosystem services \\ Ecosystem restoration and resilience \\ 15) \\ Q Access and benefit sharing genetic \\ 16) resources}
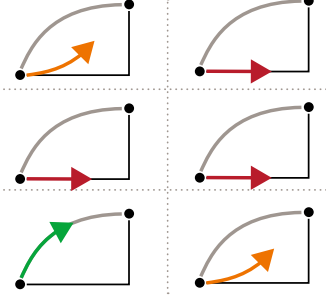

\section{3}

Biodiversity strategies and action

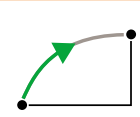

Traditional knowledge

Sharing information and knowledge

Resource mobilization
N.A.

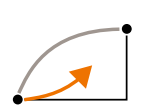

N.A.
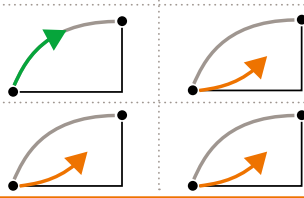

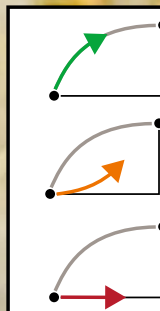

On track to exceed or achieve target

Progress towards target but at an insufficient rate

No significant change or moving away from target

+ partially effective

+ effective

— ineffective 


\section{Samenvatting}

Het Verdrag inzake biologische diversiteit (Convention on Biological Diversity, CBD) is een internationaal verdrag, geïnitieerd door het Milieuprogramma van de Verenigde Naties (UNEP). De CBD zet in op drie doelen: het behoud van biodiversiteit, het duurzaam gebruiken van biodiversiteit en een billijke verdeling van de voordelen die voortvloeien uit het gebruik van genetische rijkdommen. In 2002 hebben partijen, de ondertekenaars van de conventie waaronder Nederland, zich verplicht de achteruitgang in biodiversiteit in 2010 significant geremd te hebben. Dit ambitieuze doel is niet gehaald. Tijdens de CBDConferentie van Partijen (COP10) in Nagoya, Japan in 2010 werd daarom een Strategisch Plan voor Biodiversiteit 2011-2020 overeengekomen. Dit strategisch plan is een tienjarig kader voor actie door alle partijen om biodiversiteit te redden en de voordelen voor mensen te vergroten.

De partijen van de CBD hebben afgesproken elke vier jaar over de implementatie van het strategische plan te rapporteren. Deze zesde rapportage (2019) heeft de CBD de partijen verzocht te rapporteren over:

1 de nationale doelen voor biodiversiteit,

2 de genomen uitvoeringsmaatregelen om de doelen te halen,

3 beoordeling van de effectiviteit van deze maatregelen,

4 beoordeling van de voortgang van elk nationaal doel,

5 beschrijving van de nationale bijdrage aan het bereiken van elk van de wereldwijde Aichi-biodiversiteitsdoelen. Deze Aichi-biodiversiteitsdoelen zijn onderdeel van het Strategisch Plan voor Biodiversiteit 2011-2020 van de CBD. Binnen Europa zijn deze Aichi-doelen verder uitgewerkt in de EU-Biodiversiteitsstrategie 2020 met zes doelstellingen.

De zesde nationale rapportage wordt op de COP gebruikt om de stand van zaken voor de uitvoering van de CBD te beoordelen. Het biedt informatie voor de vijfde 'Global Biodiversity Outlook', een periodiek rapport dat de meest recente gegevens over de status en trends van biodiversiteit samenvat en conclusies trekt die relevant zijn voor de verdere implementatie van het CBD-verdrag. Voor Nederland wordt onderscheid gemaakt in het Europese en Caribische deel van het Koninkrijk.

\section{Natuur en biodiversiteit in Europees Nederland}

Nederland is een van de dichtstbevolkte landen ter wereld en het grootste deel van het landoppervlak is zeer productieve landbouwgrond. Allerlei maatregelen om de landbouwproductie te verhogen, zoals de ontwatering van natte gebieden en het gebruik van kunstmest, maar ook verstedelijking, vervuiling en overbevissing hebben afgelopen eeuw geleid tot een achteruitgang van biodiversiteit. Er is weinig of geen gebied dat ongerept kan worden genoemd. Bijna $40 \%$ van de soorten in Nederland staan op de Rode Lijst en worden in meer of mindere mate bedreigd, $96 \%$ van de habitattypen en $77 \%$ van de habitatrichtlijnsoorten hadden in 2013 een zeer- of matig ongunstige staat van instandhouding. Ondanks deze achteruitgang zijn er nog steeds hoge biodiversiteitswaarden aanwezig. Zo is het Nederlandse deel van de Waddenzee Unesco-werelderfgoed en een cruciale tussenstopplaats voor miljoenen Afrikaans-Euraziatische trekvogels.

\section{Doelen en maatregelen voor biodiversiteitsbehoud en -herstel}

Om de achteruitgang in biodiversiteit te keren, heeft Nederland verschillende doelen voor biodiversiteit opgesteld en geïmplementeerd. Nederland heeft de zes doelstellingen uit de EU-Biodiversiteitsstrategie opgenomen als nationale doelen. Deze 'nationale' doelen gaan over:

- het verbeteren van de staat van instandhouding van soorten en habitattypen,

- het verbeteren en herstellen van ecosystemen en van ecosysteemdiensten,

- het behoud van soorten en habitattypen die worden beïnvloed door de landbouw en bosbouw,

- het duurzaam gebruik van visbestanden; de visserij heeft geen significante nadelige gevolgen voor soorten en ecosystemen,

- het bestrijden van invasieve exoten,

- het leveren van een bijdrage aan het voorkomen van wereldwijd biodiversiteitsverlies. 
De zes belangrijkste maatregelen die Nederland neemt om deze doelen te bereiken, zijn:

- het creëren van nieuwe natuur in een samenhangend netwerk van natuurgebieden,

- wettelijke bescherming van bedreigde soorten en natuurgebieden,

- subsidies voor beheermaatregelen,

- een programmatische aanpak van stikstof,

- het stimuleren van duurzaam gebruik van natuurlijk kapitaal, en

- het benutten van de zelforganiserende capaciteiten van de samenleving.

In de Rijksnatuurvisie (2014) heeft het Rijk de inzet van het natuurbeleid verbreed naar een insteek waarin het nut van natuur, bestaande uit goederen en diensten, meer aandacht krijgt. In de 'Uitvoeringsagenda Natuurlijk Kapitaal' (2013) zijn activiteiten geformuleerd die door het Rijk en maatschappelijke partners worden ondernomen om het beoogde einddoel te bereiken: behoud, duurzaam en eerlijk gebruik van het natuurlijk kapitaal in 2020. De Nederlandse overheid heeft de verantwoordelijkheid voor natuurherstel en natuurbeheer gedecentraliseerd naar de provincies (Natuurpact 2013).

\section{Maatregelen zijn gedeeltelijk effectief}

Aanzienlijke inspanningen zijn gedaan om de bestaande natuur en biodiversiteit te beschermen en te herstellen en om 'nieuwe' natuurlijke gebieden te creëren. Sinds 2011 is er 33.000 ha nieuwe natuur bijgekomen en sinds 2005 is de barrièrewerking van 114 infrastructurele knelpunten opgeheven met behulp van ecoducten en andere faunapassages. Er is echter onvoldoende vooruitgang geboekt om de nationale doelstellingen volledig te bereiken, terwijl de belangrijkste maatregelen als gedeeltelijk doeltreffend worden beschouwd. Het Natuurnetwerk Nederland (NNN, voorheen EHS), de hoeksteen van het behoud van biodiversiteit in Nederland, wordt pas in 2027 voltooid. Ondanks de huidige focus op essentiële ecosysteemdiensten in Nederland, bevinden de analyse en evaluatie van de meeste diensten zich nog in een vroeg stadium, evenals het proces om deze te beschermen en te herstellen.

Een toenemend aantal mensen en bedrijven ondernemen acties voor biodiversiteit en duurzame productie, consumptie en handel. Het Programma Aanpak Stikstof (PAS), een belangrijk instrument om de milieucondities in natuurgebieden te verbeteren, mag niet als basis voor toestemming voor stikstof uitstotende activiteiten worden gebruikt. De Raad van State heeft eind mei 2019 geoordeeld dat de PAS onvoldoende onderbouwd is om vergunningen voor nieuwe activiteiten te verstrekken.

\section{De vooruitgang is onvoldoende om de doelstellingen te halen}

Door de genomen maatregelen is er veel vooruitgang geboekt. De vooruitgang is echter onvoldoende om de nationale doelstellingen binnen de gestelde termijn vóór 2020 te halen. Zo neemt zowel het aantal rode-lijstsoorten als de gemiddelde mate van bedreiging van deze soorten na voorzichtig herstel weer toe. Het is echter vooral de agrobiodiversiteit die nog steeds afneemt, ondanks alle positieve en substantiële inspanningen zoals het gemeenschappelijk landbouwbeleid en agromilieuprogramma's. De populatie boerenlandvogels is sinds 1990 met 30\% afgenomen, de vlinders in agrarische graslanden nemen af en $72 \%$ van de natuur heeft in 2016 nog steeds min of meer te lijden van stikstofdepositie die grotendeels afkomstig is uit de landbouw.

Ook de visserij is nog niet volledig duurzaam. Volgens de Nederlandse Mariene Strategie voldoet slechts $26 \%$ van de commerciële vis, schaal- en schelpdierbestanden aan een goede milieutoestand (op basis van de criteria 'visserijsterfte' en 'biomassa van het paaibestand'). Ook de populaties van (langlevende) haaien, roggen en veel op de bodem levende soorten, welke vooral zijn afgenomen als gevolg van de visserij, herstellen zich nog steeds niet. Belangrijke visbestanden als haring, tong en schol worden momenteel wel als duurzaam beschouwd.

Er zijn belangrijke stappen gezet om de effecten van het gebruik van natuurlijke hulpbronnen binnen veilige ecologische grenzen te houden. Het marktaandeel van een aantal in Nederland geïmporteerde biotische grondstoffen zoals hout, soja, palmolie en koffie met een duurzaamheidslabel is de afgelopen decennia aanzienlijk toegenomen. Hoewel er redelijke vooruitgang is geboekt, is de weg naar duurzaamheid lang.

\section{Bijdrage aan de Aichi-doelen}

Net als de nationale doelen, worden de meeste Aichidoelen beoordeeld als 'vooruitgang in de richting van het doel'. Verschillende Achi-doelen zijn 'behaald of op schema om het doel te overschrijden in 2020', terwijl de vooruitgang in de richting van enkele andere doelen 'geen significante verandering' laat zien. Zo zijn de beschermde 
gebieden in Nederland (Natuurnetwerk Nederland incl. Natura 2000) goed voor meer dan 17\% (= doelstelling) van het land- en binnenwatergebied en $10 \%$ van de kust- en zeegebieden, maar is het Aichi-doel nog niet bereikt omdat de milieuomstandigheden een aanzienlijk negatief effect hebben op de staat van instandhouding van deze beschermde gebieden. Vermeldenswaard is dat het verzamelen, delen en toepassen van kennis over biodiversiteit (Aichi-target: Knowledge improved, shared and applied) zeer goed ontwikkeld is in Nederland waardoor dit doel al ruim voor 2020 is bereikt.

\section{Natuur en biodiversiteit op de Nederlandse Caribische eilanden}

Het Koninkrijk der Nederlanden omvat ook zes Caribische eilanden (Caribisch Nederland met daarbinnen de drie eilanden Bonaire, Saba en St. Eustatius en de drie zelfstandige landen binnen het Koninkrijk: Curaçao, Aruba en St. Maarten), die onderdeel zijn van de Caribische Biodiversiteitshotspot. Hier komen habitats voor variërend van tropisch nevelbos en zoutmeren tot mangrovebossen en koraalriffen, die het leefgebied vormen van honderden endemische en bedreigde soorten. De ecosystemen van de eilanden zijn kwetsbaar. De meeste habitats zijn klein, net als de soortenpopulaties die ervan afhankelijk zijn, terwijl de bedreigingen groot zijn.

Data van langetermijnmonitoring zijn schaars en dat geldt ook voor trendanalyses en indicatoren. De Aichi-doelen zijn daarom, voor elk eiland afzonderlijk, vooral beoordeeld op basis van (lokale) expert-kennis. De eilanden van Caribisch Nederland staan er wat beter voor dan de andere drie eilanden, maar over het algemeen liggen de Aichi-biodiversiteitsdoelen niet op schema. Soms is zelfs sprake van een achteruitgang. Dit komt door de vele lokale bedreigingen, zoals overbegrazing en erosie als gevolg van duizenden loslopende geiten en ander vee, vervuiling, invasieve exoten en overbevissing. De ecosystemen hebben daardoor ook minder veerkracht om de verwachte negatieve gevolgen van klimaatverandering op te kunnen vangen. De acties om de verschillende bedreigingen het hoofd te bieden, zijn nog onvoldoende om in 2020 de Aichi-biodiversiteitsdoelen te behalen. Uiteindelijk zal dit ook de eilandeconomieën raken, omdat deze (met name de sectoren toerisme en visserij) sterk afhankelijk zijn van ecosysteemdiensten. 


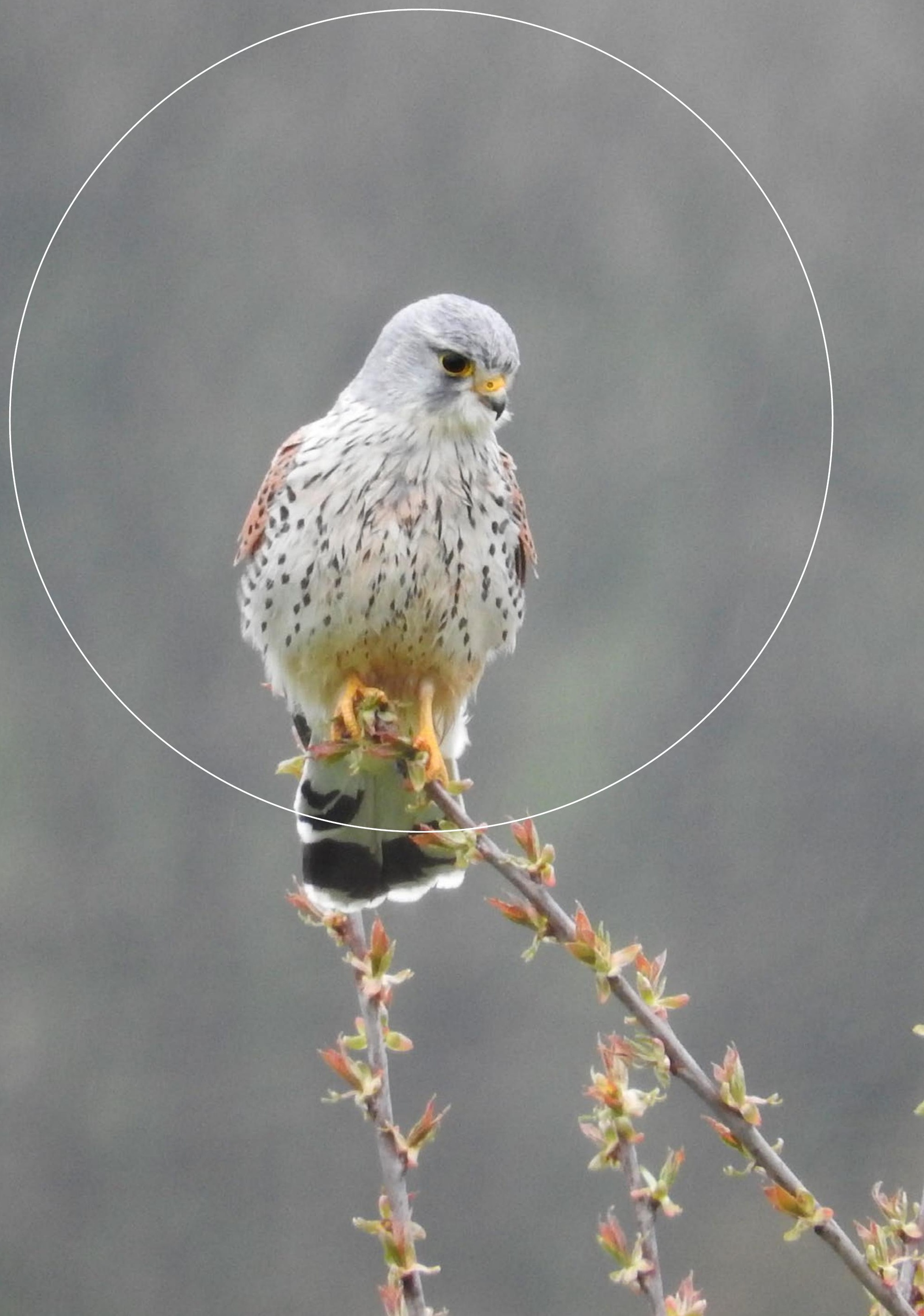




\section{Executive Summary}

\section{Background}

The Convention on Biological Diversity (CBD) is an international treaty initiated by the United Nations Environment Programme (UNEP). The Strategic Plan for Biodiversity 2011-2020 was agreed at the tenth meeting of the CBD Conference of Parties (COP10) in Nagoya, Japan in 2010. The Strategic Plan for Biodiversity includes five interdependent Strategic Goals and a set of 20 Aichi Biodiversity Targets, most with an end-point of 2020. The sixth national report is used by the Conference of the Parties to assess the status of implementation of the CBD. It provides information for a global biodiversity outlook of progress towards the implementation of the Strategic Plan for Biodiversity 2011-2020 and progress towards the Aichi Biodiversity Targets. The sixth national report guidelines ask Parties to report on 1) national targets, 2) main measures, 3) the effectiveness of these measures, 4) progress towards the national targets, and 5) progress towards the achievement of each Aichi Biodiversity Target.

\section{Key messages}

There has been significant and reasonable progress towards the national targets, but the 2020 deadline will not be reached. The Netherlands is one of the most densely populated countries in the world and most of the country's land area is highly productive agricultural land. Reclamation of semi-natural areas, the drainage of wet areas, use of artificial fertiliser, etc., all to increase agricultural production, as well as expanding urbanisation and infrastructure due to the growth in population size and mobility have contributed to the long-term decline (over the 20th century) of populations of species and to the decline habitats. The path to sustainability and achieving the targets is a long one.

Considerable effort has been invested in safeguarding and restoring existing nature as well as in creating 'new' natural areas. However, in most cases progress has been insufficient to fully achieve the 2020 targets while the main measures are considered to be partly effective. For example, the national ecological network (NEN), the cornerstone of biodiversity conservation in the Netherlands, is still in the process of being established and is due for completion in 2027, and environmental impacts, especially from agriculture, are still a major concern. However, there also has been significant progress towards meeting several components of most of the Aichi Biodiversity Targets. Some target components, such as conserving at least $17 \%$ of the terrestrial and inland water area, have been met.

The Kingdom of the Netherlands also includes six islands within the Caribbean Islands Biodiversity Hotspot, with tropical rainforests, coral reefs and hundreds of endemic and threatened species. The island ecosystems are fragile. Most habitats are small, as are the species populations that depend on them, while the threats are high. Most Aichi Biodiversity Targets are not on track due to local threats, including free-roaming grazing livestock, pollution, invasive species and overfishing, which also make the island ecosystems less resilient to the major threat of climate change. The island economies are very much dependent on ecosystem services, especially tourism and fisheries. However, the actions to deal with these local threats (if any) are generally insufficient. This is illustrated by the fact that progress towards five of the Aichi Targets has actually been negative, while no significant change can be observed for $50 \%$ of the targets on some of the islands.

\section{National targets and main measures}

In 2011 the European Commission adopted a strategy to halt the loss of biodiversity and ecosystem services in the EU by 2020. The Netherlands has committed itself to objectives in the EU Biodiversity Strategy and thus indirectly to those in the CBD. The national targets are based on the European targets and related to the Aichi Biodiversity Targets (Appendix 1). For the Kingdom of the Netherlands in Europe there are six main targets:

1 By 2020, the assessments of species and habitats protected by EU nature law show better conservation or a secure status for $100 \%$ more habitats and $50 \%$ more species. 
2 By 2020, ecosystems and their services are maintained and enhanced by establishing green infrastructure and restoring at least $15 \%$ of degraded ecosystems.

3 By 2020, the conservation of species and habitats depending on or affected by agriculture and forestry, and the provision of their ecosystem services, show measurable improvements.

4 By 2015, fishing is sustainable. By 2020, fish stocks are healthy and European seas healthier. Fishing has no significant adverse impacts on species and ecosystems.

5 By 2020, invasive alien species are identified, priority species controlled or eradicated, and pathways managed to prevent new invasive species from disrupting European biodiversity.

6 By 2020, the EU has stepped up its contribution to avert global biodiversity loss.

The six main measures of the Kingdom of the Netherlands in Europe are:

1 create new habitat within the national ecological network (NEN) with the aim of establishing viable species populations;

2 the Nature Conservation Act, an important instrument for species and habitat conservation;

3 subsidies for conservation management measures important for maintaining biodiversity;

4 the Programmatic Approach to Nitrogen (PAN);

5 stimulating sustainable use of natural capital and mainstreaming nature for the benefit of society and the economy;
6 utilising the self-organising capacities of society by stimulating, facilitating and financially support green initiatives.

In the last seven years the Dutch government has decentralised the responsibility for nature restoration and conservation management to the provinces. In 2013, ambitions for 2027 were agreed upon and set down in the Nature Pact between the national government and the provinces, including agreements on expanding the NEN, improving environmental conditions, improving the system of conservation management by farmers and more cross-sectoral strategies to integrate conservation management into other land uses.

\section{Main measures and their effectiveness}

The above six main measures are taken to achieve the six national targets. Each main measure is not geared towards achieving a single target, but contributes towards the achievement of several targets (Appendix 1 ). In theory, contributing to several targets at the same time increases the potential success of a measure. However, interactions between measures and targets, as well as the complex causal relations in ecology, make it difficult to assess how effective the measures taken have been. The results below show that progress has been made and that the measures do contribute towards several targets, although the targets will not be met in 2020. The tools or means (indicators and monitoring) for assessing progress towards the national targets are described in Appendix 2.

\begin{tabular}{l|l|l|l|l|l|l} 
& \multicolumn{7}{|c}{ Main measures } \\
\hline Measure taken has been: & $\mathbf{1}$ & $\mathbf{2}$ & $\mathbf{3}$ & $\mathbf{4}$ & $\mathbf{5}$ & $\mathbf{6}$ \\
\hline effective & & & & & & \\
\hline partially effective & & & & & & \\
\hline ineffective & & & & & & \\
\hline unknow & & & & & & \\
\hline
\end{tabular}

\author{
Main measures \\ 1 National ecological network (NEN) \\ 2 The Nature Conservation Act \\ 3 Subsidies for management measures \\ 4 Programmatic Approach to Nitrogen (PAN) \\ 5 Stimulating sustainable use of natural capital \\ 6 Utilising the self-organising capacity of society
}

Table 1 Estimated effectiveness of main measures

'Partially effective' means, according to the CBD, that "progress towards the stated target has begun, however the complete desired outcome has not yet been achieved. This could be due to time lags between when the measure was taken and when its effects become visible. It could also be due to national circumstances creating delays or challenges to the implementation of the measure. Other possible reasons for a measure being given this assessment are that the measure has not been implemented at the scale necessary or at the appropriate institutional level." 
The obstacles and scientific and technical needs related to the measures taken are described in Appendix 3. Based on the results and indicators described below, the complex relations, the progress towards the targets and our expert knowledge, we conclude that the measures taken have been partially effective (Table 1 ).

The NEN (main measure 1), including 161 EU Natura 2000 sites, is the cornerstone of biodiversity conservation in the Netherlands. All large waters, such as the North Sea and the Wadden Sea, are part of the NEN and large parts of these waters are protected Natura 2000 sites. The development of the NEN began in 1990 and it is still increasing in size. The degree of fragmentation of the NEN by infrastructure and fragmentation of rivers and streams by obstacles is being reduced. The NEN is still in the process of being established and is due for completion in 2027. Along with subsidies for management measures (main measure 3) and a substantial decline in environmental pressures, the NEN has slowed down the average rate of biodiversity loss in the Netherlands. The Programmatic Approach to Nitrogen (main measure 4) is the most important measure for improving environmental conditions necessary for biodiversity protection in the Netherlands. On 31 March 2018, more than $28 \%$ of the restoration measures to be implemented had been completed in the first PAN period. However, reported nitrogen deposition and emissions of ammonia have increased slightly following many years of decline.

Urbanisation, transport and industrial, agricultural and fisheries activities cause environmental pressures on biodiversity. The reforms of the EU common agriculture policy and common fisheries policy may turn out to be milestones in reducing these impacts and improving the sustainable use of the components of biological diversity. Also important in this respect is legislation on environmental and spatial issues (main measure 2).

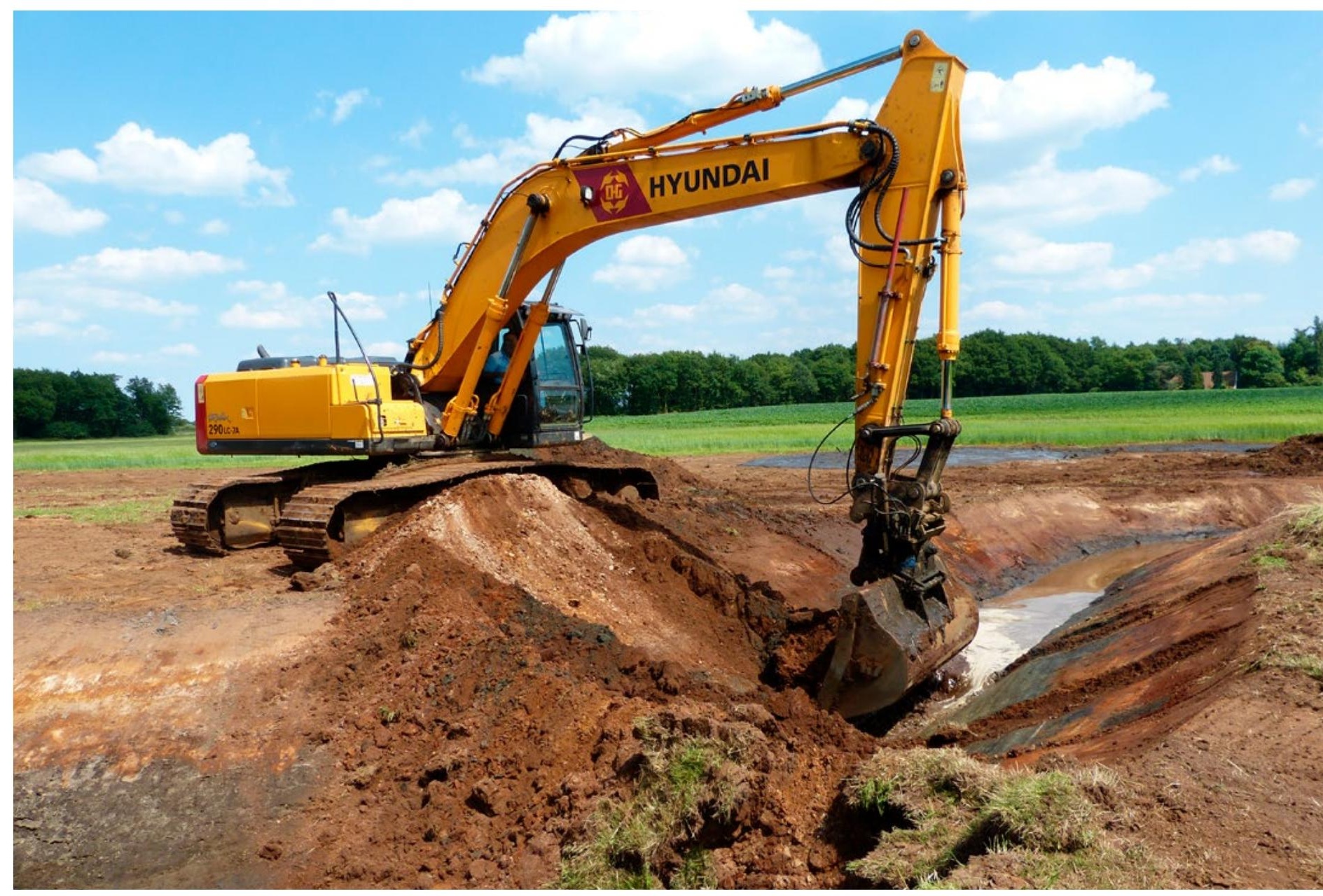




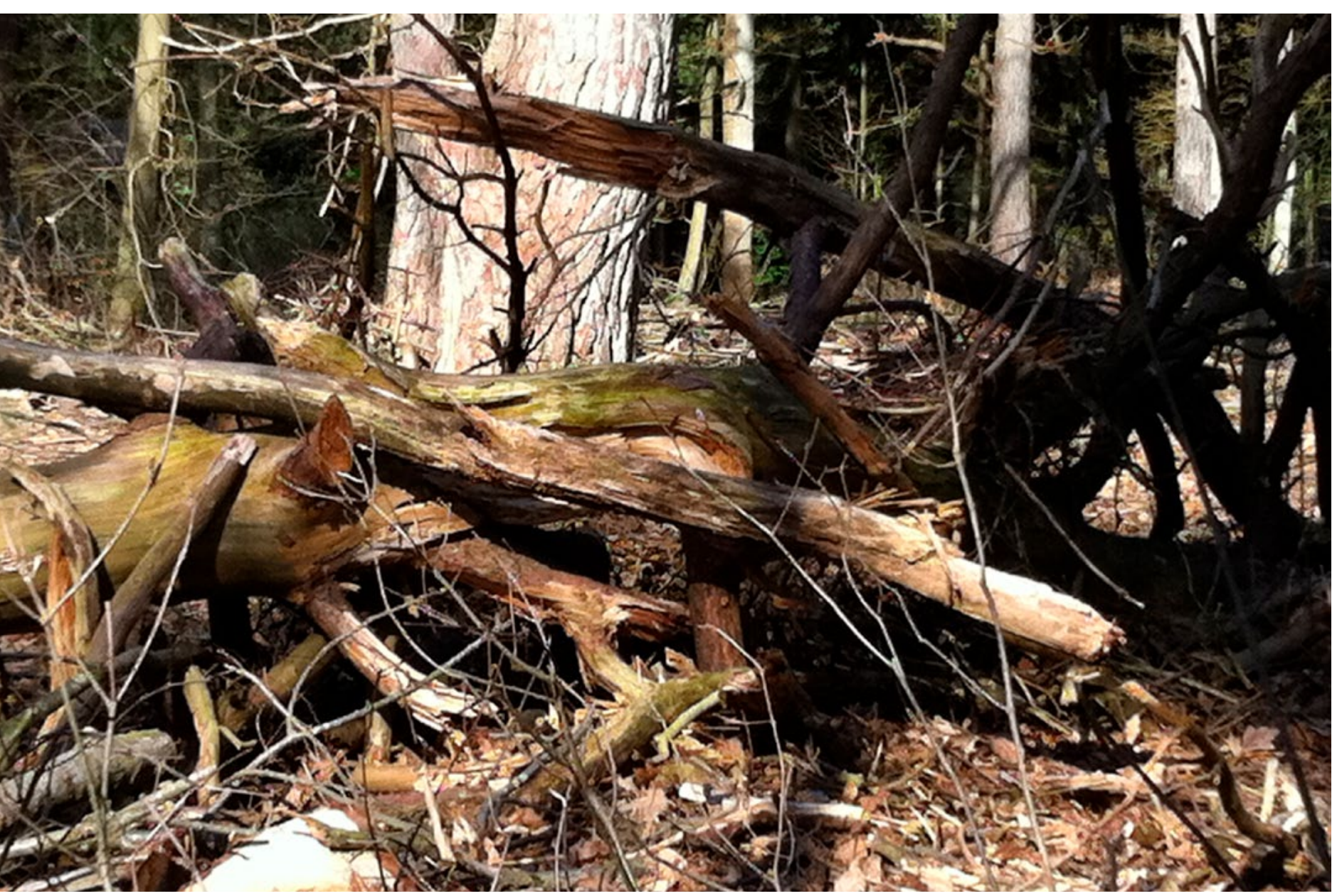

The Dutch government is stimulating the sustainable use of natural capital (main measure 5). An increasing number of people and businesses are taking actions for the benefit of biodiversity and sustainable production, consumption and trade are increasing. Internationally, the Netherlands is also working on biodiversity-related issues with the aim of preventing negative impacts on tropical forests, mangrove forests, marine and other ecosystems. The government is working on constraints on the trade in endangered species and products made from them, in part via support for sustainable development programmes in its development cooperation portfolio and via climate funding, and in part by facilitating the formation of coalitions of Dutch businesses, knowledge institutes and government institutions around value chains that are critical to biodiversity, such as timber, soy, palm oil and shrimps.

The Dutch government is utilising the self-organising capacities of society (main measure 6). Awareness in society of the need to conserve nature is relatively high and ecological data and knowledge is effectively shared and used, but the conservation of genetic diversity for animal breeds is still a concern. In consultation with civil society groups the Dutch government has prepared a number of biodiversity policy documents contributing to the CBD goals.
Summary of progress towards national targets

Progress towards the national targets (Table 2) was determined from available assessments, available indicators and expert judgement based on the estimated level of confidence and monitoring related to the target (Appendix 2).

The latest assessment of the conservation status of habitats and species was published in 2013. A new assessment is expected to be published in mid-2019. In the Netherlands, $10 \%$ of the habitat types with an unfavourable conservation status showed an improvement, while no less than $27 \%$ worsened. The Habitats Directive species show a slightly better trend: more than $40 \%$ of the species with an unfavourable status improved, while the status of $11 \%$ worsened. The population trends of Birds Directive species in the Netherlands for the period 2001-2012 were variable: the status of $39 \%$ of the breeding birds improved, while the status of $37 \%$ worsened. Other indicators of species and habitats show similar results. The status of Red List species (RLI) showed a small and fragile improvement, the population size of ecosystem characteristic species increased (LPI) and biological water quality improved. 
Despite the current focus on essential ecosystem services in the Netherlands, the analysis and evaluation of most services is still at an early stage, as is the process towards safeguarding and restoring them. A successful initiative for restoring ecosystem services in combination with water management, climate adaptation and public safety was the Room for the River programme, which has opened up more room in the floodplains of the main rivers for dynamic processes and increased capacity to accommodate and manage higher river discharge levels. The impacts of pesticides on nature, especially on bees, is currently attracting much attention. The number of bee species in the Netherlands on the Red List increased between 2003 and 2018.

The agriculture sector has made less progress towards sustainability than the forestry sector. Agro-biodiversity is still decreasing, despite all positive and substantial efforts such as the common agricultural policy and agri-environmental schemes. In response to this lack of progress, a social movement has arisen to work towards circular nutrient cycles and nature-inclusive agriculture across the entire agricultural sector, not only in the $10 \%$ of agricultural areas that are under agri-environmental management. Populations of typical forest breeding birds are increasing on average, while forest butterflies show a more mixed picture. In general, agro-biodiversity is moving away from the target, while forest biodiversity is improving. Local situations may show a much different picture though.
The common fisheries policy stipulates that between 2015 and 2020 catch limits should be set that are sustainable and maintain fish stocks over the long term. Important fish stocks (herring, sole, plaice) are currently considered sustainable. Cod is not, which illustrates that not all fish stocks and effects of unsustainable fishing have been restored yet. The populations of vulnerable long-lived shark, ray and many benthic species have decreased since 1990 and are still not recovering.

The invasive alien species and pathways have been identified and measures are being taken, but the number of invasive alien species in the Netherlands is still increasing (data to 2016). Introduction pathways such as trade and use are regulated by law. The Nature Conservation Act prohibits the release of animal and plant species in the wild and the possession of and trade in certain alien species. The law makes it possible to act when invasive alien species are introduced. Control and eradication of invasive alien species is much more difficult in water than on land, which emphasises the need for prevention. The species on the Union list have been controlled or eradicated.

Major steps have been taken to keep the impacts of natural resource use within safe ecological limits, although concern still exists about the reform of the agricultural sector and the ecological footprint of the Netherlands, especially abroad. The market shares of a number of biotic raw materials imported into the Netherlands with a sustainability label has increased substantially over the past few decades. The path to sustainability is long, although reasonable progress has been made.

\begin{tabular}{l|c|c|c|c|c|c} 
& \multicolumn{7}{|c|}{ National targets } \\
\hline Assessment & $\mathbf{1}$ & $\mathbf{2}$ & $\mathbf{3}$ & $\mathbf{4}$ & $\mathbf{5}$ & $\mathbf{6}$ \\
\hline On track to exceed target & & & & & & \\
\hline On track to achieve target & & & & & & \\
\hline Progress towards target & & & & & & \\
\hline No significant change & & & & & & \\
\hline Moving away from target & & & & & & \\
\hline Unknown & & & & & & \\
\hline
\end{tabular}

National targets

1 Better conservation of species and habitats

2 Maintain and enhance ecosystem services

3 Better conservation of species and habitats affected by agriculture and forestry

4 Sustainable fisheries

5 Invasive alien species controled, eradicated, prevented

6 Contribution to avert global biodiversity loss

Table 2. Progress towards national targets

'Progress towards target' means, according to the $C B D$, that "significant progress towards the attainment of the target has been made. The progress could take the form of measures being taken or actual improvements in the status of the issues being addressed. However, while this category indicates an improving situation, the progress that has been made will be insufficient for the target to be met by the deadline $(=2020)$ unless further measures are taken." 


\section{Summary of progress towards the Aichi Biodiversity Targets in the European Netherlands}

Progress towards the Aichi Biodiversity Targets was determined from assessments, indicators and expert judgement, taking the estimated level of confidence and monitoring related to the target into account

(Appendix 2). Many of the Aichi Biodiversity Targets are related to the national targets and the main measures taken. These relations are described in Appendix 1. In contrast to the national targets, progress has not been restricted to one category (Table 3 ).

Like the national targets, progress towards most Aichi Targets is assessed as 'progress towards target'. Several Achi Targets are 'achieved or on track to exceed target' while progress towards a few others shows 'no significant change'. Below we describe the targets for which progress has been assessed other than 'progress towards target'.

Aichi Targets 1, 16, 17 and 19 may be regarded as having been achieved. Based on the current status and positive trend of biodiversity awareness (Target 1 ) and the relevant ongoing initiatives, it can be concluded that awareness is relatively high and still increasing. Access and benefit sharing is in force and operational (Target 16) and the Netherlands has developed and implemented several national biodiversity strategy and action plans (Target 17). Furthermore, sharing information and knowledge (Target 19 ) is very well developed in the Netherlands and can be considered to have been achieved.

An important part of Aichi Targets 11 and 13 may be regarded as having been achieved, but some aspects have not yet been achieved. Although the protected areas in the Netherlands amount to well over $17 \%$ of the terrestrial land and inland water area and $10 \%$ of coastal and marine areas, Aichi Target 11 has not yet been achieved because environmental conditions have a substantial negative impact on the conservation status of the protected areas. Aichi Target 13, safeguarding genetic biodiversity, has not been achieved. Many animal breeds are still at risk. Crop genetic diversity is not at risk, although this is largely conserved in ex situ collections.

Aichi Target 8, 9 and 15 showed no significant change. Although pollution (Target 8 ) has been significantly reduced in the Netherlands, several target levels have still not been met, especially for nitrogen. On average, nitrogen deposition has not decreased since 2010 and critical load exceedance is still significant in large areas. Furthermore, the number of potentially invasive alien species (Target 9) is still increasing, despite many preventive actions and prioritisation of invasive species and pathways. Aquatic species present a major management challenge. Finally, ecosystem restoration (Target 15 ) has not been achieved yet, mainly because of the degradation of peatland areas, which emit several Mtonnes of $\mathrm{CO}_{2}$ as a result of land drainage.

\section{Summary of progress towards Aichi Biodiversity Targets in the Caribbean islands}

Long-term monitoring data are scarce for each of the six Dutch Caribbean islands and trend analyses and indicators are therefore scarce as well. The 20 Aichi Targets were assessed mainly on the basis of expert judgement. The Caribbean Netherlands is generally more on track towards achieving the Aichi Targets than the constituent countries Aruba, Curaçao and Sint Maarten, probably due to a substantial increase in actions after 10 October 2010 when the islands of the Caribbean Netherlands became public bodies of the Netherlands. 


\begin{tabular}{|l|l|l|l|l|l|l|l|l|l|l|l|l|l|l|l|l|l|l|l|l|l|l|}
\hline Assessment & $\mathbf{1}$ & $\mathbf{2}$ & $\mathbf{3}$ & $\mathbf{4}$ & $\mathbf{5}$ & $\mathbf{6}$ & $\mathbf{7}$ & $\mathbf{8}$ & $\mathbf{9}$ & $\mathbf{1 0}$ & $\mathbf{1 1}$ & $\mathbf{1 2}$ & $\mathbf{1 3}$ & $\mathbf{1 4}$ & $\mathbf{1 5}$ & $\mathbf{1 6}$ & $\mathbf{1 7}$ & $\mathbf{1 8}$ & $\mathbf{1 9}$ & $\mathbf{2 0}$ & $\mathbf{1}$ \\
\hline Achieved or on track to exceed target & & & & & & & & & & & & & \\
\hline On track to achieve target & & & & & & \\
\hline Progress towards target & & & & & & & & & \\
\hline No significant change & & & & & & & & & & & & & \\
\hline Moving away from target & & & & & & & & & & & & & & \\
\hline Unknown & & & & \\
\hline
\end{tabular}

Table 3. Progress towards the Aichi Biodiversity Targets. The light green squares in Table 3 indicate where progress on part of the target has been assessed to be in a different category from the whole target.

Aichi Biodiversity Targets Caribbean overseas territories Kingdom of the Netherlands

\begin{tabular}{|l|l|l|l|l|l|l|l|l|l|l|l|l|l|l|l|l|l|l|l|l|l|l|l|}
\hline Assessment & $\mathbf{1}$ & $\mathbf{2}$ & $\mathbf{3}$ & $\mathbf{4}$ & $\mathbf{5}$ & $\mathbf{6}$ & $\mathbf{7}$ & $\mathbf{8}$ & $\mathbf{9}$ & $\mathbf{1 0}$ & $\mathbf{1 1}$ & $\mathbf{1 2}$ & $\mathbf{1 3}$ & $\mathbf{1 4}$ & $\mathbf{1 5}$ & $\mathbf{1 6}$ & $\mathbf{1 7}$ & $\mathbf{1 8}$ & $\mathbf{1 9}$ & $\mathbf{2 0}$ & \\
\hline On track to exceed target & & & & & & & & & & & & & & & & & & & & & \\
\hline On track to achieve target & & & & & & & & & & & & & & \\
\hline Progress towards target but at an insufficient rate & & & & & & \\
\hline No significant change & & & & & & \\
\hline Moving away from target & & & & & & & & & \\
\hline Unknown & & & & & & & & & & & & & & & \\
\hline
\end{tabular}

Table 4. Progress towards the Aichi Biodiversity Targets

\section{Address the underlying drivers}

1 Awareness of biodiversity increased

2 Biodiversity values integrated

3 Incentives reformed

4 Sustainable production and consumption

\section{Reduce direct pressures}

5 Habitat loss halved or reduced

6 Sustainable management of aquatic living resources

7 Sustainable agriculture, aquaculture and forestry

8 Pollution reduced

9 Invasive alien species prevented and controlled

10 Ecosystems vulnerable to climate change

\section{Improve the status of biodiversity}

11 Protected areas

12 Reducing risk of extinction

13 Safeguarding genetic diversity

\section{Enhance the benefits to all}

14 Ecosystem services

15 Ecosystem restoration and resilience

16 Access to and sharing benefits from genetic resources

\section{Enhance implementation}

17 Biodiversity strategies and action plans

18 Traditional knowledge

19 Sharing information and knowledge

20 Mobilising resources from all sources 



\section{Introduction}

The sixth national report provides the Conference of the Parties with the information needed to assess the status of implementation of the Convention on Biological Diversity (CBD). The CBD is an international treaty initiated by the United Nations Environment Programme (UNEP). It has been ratified or accepted by 196 Parties, mostly individual countries. The Netherlands and the European Union are Parties to the CBD. The CBD entered into force on 29 December 1993 and has three main objectives:

1 The conservation of biological diversity

2 The sustainable use of the components of biological diversity

3 The fair and equitable sharing of the benefits arising out of the utilisation of genetic resources

The Strategic Plan for Biodiversity 2011-2020 was agreed at the tenth meeting of the CBD Conference of Parties (COP10) in Nagoya, Japan in 2010. The Strategic Plan for Biodiversity includes five interdependent Strategic Goals and a set of 20 Aichi Biodiversity Targets, most with an end-point of 2020. The Strategic Plan's ultimate vision for 2050 is a world where biodiversity is valued, conserved, restored and wisely used, maintaining ecosystem services, sustaining a healthy planet and delivering benefits essential for all people.

The sixth national report is used by the Conference of the Parties to assess the status of implementation of the CBD. It provides information for a global biodiversity outlook of progress towards the implementation of the Strategic Plan for Biodiversity 2011-2020 and progress towards the Aichi Biodiversity Targets. The sixth national report guidelines ask Parties to report on: national targets, main measures, the effectiveness of these measures, progress towards the national targets, and progress towards the achievement of each Aichi Biodiversity Target. This sequence is also the structure of this WOT-report.

\section{Structure of the report}

In December 2016 the Conference of the Parties (COP) adopted the guidelines, including the reporting templates, for the sixth national report. A voluntary online reporting tool is available through the Clearing-House Mechanism of the Convention and is fully aligned with the reporting templates for the sixth national report. The COP encourages Parties to submit their sixth national report through the voluntary online reporting tool. The CBD online reporting tool enables Parties to enter, review and, when appropriate, submit information requested in the guidelines for the sixth national report (decision XIII/27). The report can be exported as a pdf from the online reporting tool. However, the online report and the pdf are produced according to a fixed template which contains many textual repetitions, information about tools or means used, indicator lists, web links, information on the level of confidence of the assessment, the adequacy of monitoring and the obstacles and scientific and technical needs. This WOT-report has been produced in a more attractive and readable form than the template. Its purpose is to present the contribution made by the Kingdom of the Netherlands to the CBD objectives to a broader public. It contains the same text and indicators as the sixth national report, but the sequence of the chapters has been changed, text repetitions have been replaced by references, and indicator lists and methodological topics have been put in appendices.

\section{The Kingdom of the Netherlands}

The Kingdom of the Netherlands also includes six Caribbean islands. The islands of Saba, Sint Eustatius and Bonaire are special municipalities and together form the Caribbean Netherlands, while the islands of Sint Maarten, Aruba and Curaçao are constituent countries. The implementation of the first Caribbean Netherlands Nature Policy Plan 2013-2017 has been evaluated, while no national targets have been adopted for the other islands. The information on the Caribbean will therefore be provided in the section on the Aichi Targets. The national targets in the first four sections are for the European Netherlands. 


\section{National Targets}

The national biodiversity targets or equivalent commitments in line with the Strategic Plan for Biodiversity 2011-2020 and the Aichi Targets

The Netherlands has committed itself to nature objectives stated in the EU Biodiversity Strategy ${ }^{1}$ and thus indirectly to those in the Convention on Biological Diversity. The national targets are based on the European targets and related to the Aichi Biodiversity Targets.

The six main targets for the Kingdom of the Netherlands in Europe are the following:

1 By 2020, the assessments of species and habitats protected by EU nature law show better conservation or a secure status for $100 \%$ more habitats and $50 \%$ more species.

2 By 2020, ecosystems and their services are maintained and enhanced by establishing green infrastructure and restoring at least $15 \%$ of degraded ecosystems.

3 By 2020, the conservation of species and habitats depending on or affected by agriculture and forestry, and the provision of their ecosystem services, show measurable improvements.

4 By 2015, fishing is sustainable. By 2020, fish stocks are healthy and European seas healthier. Fishing has no significant adverse impacts on species and ecosystems.

5 By 2020, invasive alien species are identified, priority species controlled or eradicated, and pathways managed to prevent new invasive species from disrupting European biodiversity.

6 By 2020, the EU has stepped up its contribution to avert global biodiversity loss.

The links between the national targets and the Aichi Biodiversity Targets can be found in Appendix 1 .

1 http://ec.europa.eu/environment/nature/info/pubs/docs/brochures/2020\%20 Biod\%20brochure\%20final\%20lowres.pdf
Information on the targets being pursued at the national level

The rationale behind each of the national targets and the related objectives from the national biodiversity strategies and action plans (NBSAPs) are described below. The relevant conventions, directives and agreements have been implemented in national policy and legislation, including the policy documents Natural Capital Agenda ${ }^{2}$ (NCA; 2013) and the national nature vision The Natural Way Forward - Government Vision $2014^{3}$ (NV; 2014), and since the decentralisation of nature policy in the provincial Nature Visions ${ }^{4}$ (PVs) and in the Nature Pact ${ }^{5}$ (NP; 2013), the agreement between the Dutch government and the provinces on the implementation of Dutch nature policy. In these NBSAPs several objectives are related to the main targets of the EU Biodiversity Strategy.

\section{I-1 By 2020, the assessments of species and habitats protected by EU nature law show better conservation or a secure status for $100 \%$ more habitats and $50 \%$ more species.}

The Birds and Habitats Directives ${ }^{6}$ are crucial for preventing further loss of biodiversity and eventually fully restoring European biodiversity. The Directives are fully implemented in Dutch legislation (Nature Conservation Act), but 'reaching a favourable conservation status of all habitat types and species of European importance and adequate populations of naturally occurring wild bird species' (EU Biodiversity Strategy) is still a long way off. For habitats in water bodies, the EU Water Framework Directive? is an

2 https://www.cbd.int/doc/world/nl/nl-nbsap-v4-p1-en.pdf

3 https://www.cbd.int/doc/world/nl/nl-nbsap-v4-p2-en.pdf

4 https://ipo.nl/beleidsvelden/natuur

5 https://www.rijksoverheid.nl/documenten/kamerstukken/2013/09/18/ kamerbrief-natuurpact

6 http://ec.europa.eu/environment/nature/legislation/index_en.htm

7 http://ec.europa.eu/environment/water/water-framework/index_en.html 
important policy instrument for achieving good qualitative and quantitative status of these water bodies. The aim of this Directive is a 'good status' for all ground and surface waters (rivers, lakes, transitional waters and coastal waters) in the EU.

These NBSAPs derive the following objectives from the first main target of the EU Biodiversity Strategy:

- protect and improve the conservation status of species (NV, NP, PVs);

- improve environmental conditions in pursuit of the goals set by the Birds and Habitats Directives (NV, NP, PVs);

- improve spatial conditions by creating a robust national ecological network (NV, NP, PVs);

- effective regulation to protect nature and reduce burden on business and the public (NV, PVs);

- build an open, learning knowledge network: know more together; knowledge sharing to increase awareness, public support and participation (NV, NCA, PVs).

The most important NBSAP for this target is the Nature Pact. In the Nature Pact ${ }^{8}$ (2013), the ambitions for the restoration and management of nature in the Netherlands were agreed upon between the Dutch national government and the provinces for the period 2011 up to and including 2027. The focus of biodiversity policy in the Netherlands lies on the realisation and management of the national ecological network (NEN) which is due to be completed in 2027. The Natura 2000 sites are an important part of the NEN and the conservation of the Natura 2000 habitat types and species are an important part of the biodiversity policy. The Dutch government has decentralised the responsibility for habitat restoration and conservation management to the provinces. The ambitions they agreed upon include:

- protect and improve the conservation status of species set by the EU Birds and Habitats Directives;

- improve environmental conditions in pursuit of the goals set by the EU Directives;

- create a robust national ecological network;

- a more effective and regional approach to agrienvironmental management.

\section{I-2 By 2020, ecosystems and their services are maintained and enhanced by establishing green infrastructure and restoring at least $15 \%$ of degraded ecosystems.}

The EU considers our natural capital to be important because we depend on nature for food, energy, raw materials, air, water and more. The services provided by healthy ecosystems make life possible and support the economy. But many ecosystems and their services across the EU territory are now degraded and fragmented as a result of intensive agriculture, urban sprawl and grey infrastructure such as railways, roads and bridges, as well as the impacts of pollution, invasive alien species and climate change. The loss and degradation of valuable ecosystems also undermines the benefits that flow from nature to people and the economy. This target will contribute to the EU's sustainable growth and help the mitigation of and adaptation to climate change. It will also ensure protected habitats are better connected, within and between Natura 2000 areas as well as in the wider countryside. By taking nature's benefits into account in socioeconomic decisions, ecosystems can keep on providing their vital services.

The NBSAPs derive the following objectives from the second main target of the EU Biodiversity Strategy:

- regional development with nature combinations (recreation, drinking water, energy): green living and working; develop and build with nature (NV, PVs);

- future-proof nature: more room for natural processes (NV, PVs);

- improve spatial conditions by creating a robust national ecological network (NP);

- by 2020, all ecosystem services in the Netherlands will have been identified, along with recognition of their contribution to the economy, and this will be incorporated into the decision-making process of government and the private sector (NCA).

The most important NBSAP for this target is the national nature vision The Natural Way Forward ${ }^{9}$ which focuses on the protection and sustainable use of biodiversity in collaboration with citizens, businesses and civil society organisations. These societal partners have an increasing say in and responsibility for contributing to nature conser-

9 https://www.cbd.int/doc/world/nl/nl-nbsap-v4-p2-en.pdf
8 https://www.rijksoverheid.nl/documenten/kamerstukken/2013/09/18/ kamerbrief-natuurpact 


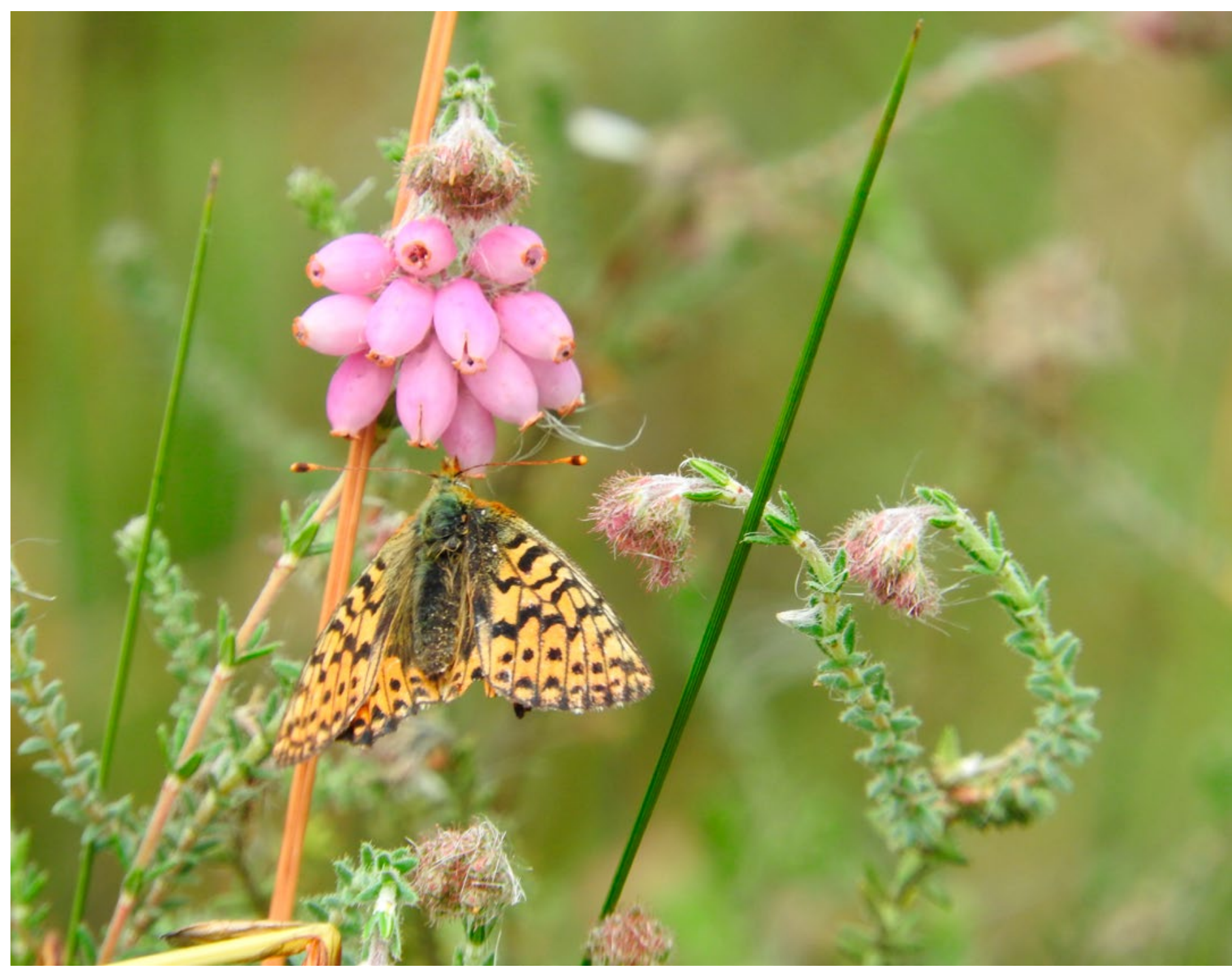

vation and habitat creation. The aim is to highlight the advantages of combining nature conservation with other social and economic interests. Citizens, businesses and civil society organisations are encouraged to incorporate nature conservation and biodiversity protection into other social and economic interests to the fullest possible extent. This policy document includes eight objectives:

- green enterprise: the driver of the economy (sustainable trade chains and consumption);

- nature-inclusive agriculture: nature and agriculture as natural partners;

- regional development with nature combinations (recreation, drinking water, landscape, energy, climate change): the region is where it is happening;

- green living and working: everything to be gained;

- future-proof nature: more room for natural processes;

- effective regulation to protect nature and reduce burden on businesses and the public;

- develop and build with nature: government sets the example;

- build an open, learning knowledge network: know more together.
The national nature vision was created with input from many stakeholders and public consultation.

\section{I-3 By 2020, the conservation of species and habitats depending on or affected by agriculture and forestry, and the provision of their ecosystem services, show measurable improvements.}

The EU gives priority role to the agriculture and forestry sectors in helping to maintain and improve biodiversity. Agriculture and forestry go hand in hand with the biodiversity on which they depend, and both have a big impact on its health. The efforts made to integrate biodiversity into agriculture and forestry in Europe are still not sufficient. By 2020, the EU wants to achieve a measurable improvement, compared to the EU2010 baseline, in the conservation of species and habitats depending on or affected by agriculture and forestry, and in the provision of their ecosystem services. 
The NBSAPs derive the following objectives from the third main target of the EU Biodiversity Strategy:

- a more effective and regional approach to agrienvironmental management (NP);

- nature-inclusive agriculture; nature and agriculture as natural partners (NV);

- by 2020 , sustainable agricultural management will be in place to ensure the conservation of biodiversity and natural capital (NCA).

Furthermore, The Netherlands has an Agricultural Vision ${ }^{10}$ : Agriculture, nature and food: valuable and connected The Netherlands as a leader in circular agriculture (LNV 2018). In this Vision one of the objectives is related to the third main target of the European biodiversity strategy. It serves as a benchmark for assessing national policy plans; one of the criteria is that they should benefit ecosystems (water, soil, air), biodiversity and the natural values of farm landscapes.

All three NBSAPs mentioned in the above list are important for this target. However, agricultural targets are also subject to other policies, such as the common agricultural policy $^{11}$ (CAP), the Water Framework Directive and the Nitrates Directive. The EU countries are permitted to define their own agricultural policy within the terms set out in the CAP. The CAP has two components: agricultural subsidies and subsidies for rural development. The amount of money available for measures that benefit biodiversity has increased with every subsequent CAP period. The Nitrates Directive aims to protect water quality across Europe by preventing nitrates from agricultural sources polluting ground and surface waters.

Unlike in many other countries, in the Netherlands forestry has a conservation objective and is not part of the agricultural domain. Forestry is generally sustainable. Most of the forested area of the Netherlands is included in the NEN and is eligible for subsidies for forest management. Almost $90 \%$ of timber used in the Netherlands is imported. Dutch policy therefore focuses on certified international timber chains to support sustainable forest management in other countries.

\section{I-4 By 2015, fishing is sustainable. By 2020, fish stocks are healthy and European seas healthier. Fishing has no significant adverse impacts on species and ecosystems.}

The EU considers that current fishing practices are not always sustainable. Not only do these activities place undue pressures on fished species, but they also damage the marine ecosystem as a whole. The EU's aim is fisheries management with no significant adverse impacts on species and ecosystems so that all European oceans and seas can be ecologically diverse and dynamic, as well as clean, healthy and productive by 2020 . The EU Marine Strategy Framework Directive ${ }^{12}$ complements the Birds and Habitats Directives and aims to protect the marine environment and establish a good environmental quality through various measures, including the designation of marine protected areas, adapting fishing activities and involving the fisheries sector in alternative activities such as ecotourism, monitoring marine biodiversity and the fight against marine litter.

One NBSAP (the NCA) ${ }^{13}$ derives the following objective from the fourth main target of the European biodiversity strategy:

- By 2020, both the aquaculture chain and the wildcaught fish chain will meet international sustainability criteria for stock management and biodiversity (NCA).

The common fisheries policy ${ }^{14}$ (CFP), the Birds and Habitats Directives and the Marine Strategy Framework Directive are the most important policies on sustainable fisheries and the marine environment. The current national target stipulates that between 2015 and 2020 catch limits should be set that are sustainable and maintain fish stocks over the long term. The CFP management plans are based on scientific advice and seek to make fishing fleets more selective in what they catch, with the aim of phasing out the practice of discarding unwanted fish.

\footnotetext{
10 https://www.rijksoverheid.nl/documenten/beleidsnota-s/2018/09/08/ visie-landbouw-natuur-en-voedsel-waardevol-en-verbonden 11 https://ec.europa.eu/agriculture/cap-overview_en
}

\footnotetext{
12 http://ec.europa.eu/environment/marine/eu-coast-and-marine-policy/ marine-strategy-framework-directive/index_en.htm

13 https://www.cbd.int/doc/world/nl/nl-nbsap-v4-p1-en.pdf

14 https://ec.europa.eu/fisheries/cfp_en
} 
The government's white paper 'Nature Ambition for the Large Water Bodies: 2050 and beyond'15 published in 2014 (in Dutch only: Natuurambitie Grote Wateren 2050 en verder) sketches a vision of resilient, robust and climate-proof ecosystems with opportunities for nature combinations such as sustainable fishing, recreation and other uses. The 'Programmatic Approach to the Ecology of the Large Water Bodies'16 (Programmatisch Aanpak Ecologie Grote Wateren) and EU LIFE IP Deltanatuur 2016-2022 programme ${ }^{17}$ set out to implement that vision for nature conservation and water quality while ensuring safety and providing for sustainable use.

\section{I-5 By 2020, invasive alien species are identified, priority species controlled or eradicated, and pathways managed to prevent new invasive species from disrupting European biodiversity.}

The EU considers invasive alien species to be a major threat to Europe's native biodiversity. They also cause economic damage amounting to billions of euros every year. This threat and damage is likely to increase in the future unless decisive and coordinated action is taken to control introduction pathways, prevent their establishment and spread, and manage already established populations. Prevention is a priority because established populations can be expensive to manage and difficult or impossible to eradicate. The IAS Regulation (Regulation (EU) 1143/2014 on invasive alien species) entered into force on 1 January 2015. A list of Invasive Alien Species of Union concern (the Union list) has been adopted and currently includes 49 species that are subject to common action at EU level as set out in the IAS Regulation. The fifth target of the EU Biodiversity Strategy is the objective of Dutch policy on invasive alien species.

The IAS Regulation ${ }^{18}$ is the most important policy on invasive alien species. It imposes restrictions on keeping, importing, selling, breeding and growing listed species. Member States are required to take measures for prevention, early detection and rapid eradication and to manage

15 https://www.rijksoverheid.nl/documenten/publicaties/2013/10/31/ beleidsverkenning-natuurambitie-grote-wateren-2050-2010

16 https://www.helpdeskwater.nl/onderwerpen/water-ruimte/ecologie/ programmatische/

17 https://life-ip-deltanatuur.nl/

18 http://ec.europa.eu/environment/nature/invasivealien/index_en.htm populations that are already widely spread in their territory. The Union list is updated at regular intervals. The Dutch Ministry of Agriculture, Nature and Food Quality asked the Netherlands Food and Consumer Product Safety Authority (NVWA) to advise on the Dutch approach per Union list species. This advice has been laid down in a strategy document on Union list species published in September 2016 (Onderbouwing strategie Unielijstsoorten ${ }^{19}$ ). The NVWA also advised the ministry of species that might be added to the Union list. The risk of additional alien species becoming invasive has been assessed and reported on by the NVWA's Invasive Alien Species Team (Team Invasieve Exoten) and species experts ${ }^{20}$.

To prevent the introduction of marine alien species via the ballast water of ships, in 2010 the Netherlands signed the International Convention for the Control and Management of Ships' Ballast Water and Sediments (BWM) under the auspices of the International Maritime Organization (IMO) ${ }^{21}$. The essence of this agreement is that ships must have an approved ballast water treatment plant which removes organisms. The Convention has been signed by 66 Parties representing $75 \%$ of world trade tonnage and entered into force on 8 September 2017.

\section{I-6 By 2020, the EU has stepped up its contribution to avert global biodiversity loss.}

The EU is committed to stepping up its contribution to averting global biodiversity loss. The EU derives great benefits from global biodiversity, but some of its consumption patterns are an important cause of biodiversity loss and habitat degradation beyond EU borders. The EU Biodiversity Strategy to 2020 is in line with international commitments made in October 2010, when the UN Convention on Biological Diversity adopted a strategic plan to address global biodiversity loss over the next decade. The EU is stepping up its contribution to averting global biodiversity loss by greening its economy and endeavouring to reduce its pressure on global biodiversity.

19 https://www.nvwa.nl/documenten/dier/dieren-in-de-natuur/exoten/ publicaties/onderbouwing-strategie-unielijstsoorten

20 https://www.nvwa.nl/onderwerpen/invasieve-exoten/ risicobeoordelingen--reactieperiode-invasieve-exoten

21 http://www.imo.org/en/About/Conventions/ListOfConventions/Pages/ International-Convention-for-the-Control-and-Management-of-Ships\%27Ballast-Water-and-Sediments-(BWM).aspx 
These NBSAPs derive the following objectives from the sixth main target of the EU Biodiversity Strategy:

- by 2020 , the most important agricultural raw material chains will meet sustainability criteria for biodiversity (NCA);

- fair agreement on the use of plant genetic resources (NCA);

- green enterprise: driver of the economy (NV).

The most important NBSAP for this target is the Natural Capital Agenda22. This policy plan focuses on the conservation and sustainable use of biodiversity, both nationally and internationally. The strategy's objective is to secure resilient ecosystems and ecosystem services that contribute to biodiversity, water and food security, welfare and combating poverty. Developing a nature-inclusive economy and securing international biodiversity are important elements of nature policy.
Ecosystem services protection focuses on the implementation and management of natural capital and sustainable production and consumption mostly outside the Netherlands. It has four general objectives (which includes 16 action points):

1 By 2020, the most important agricultural raw material chains will meet sustainability criteria for biodiversity, with fair agreement on use of plant genetic resources.

2 By 2020, both the aquaculture chain and the wildcaught fish chain will meet international sustainability criteria for stock management and biodiversity; overfishing within EU waters will have been halted as a condition for restoring fish populations; seabed life and the quality of the marine environment will be improved; international Marine Protected Areas will have been introduced to protect biodiversity and overfishing and pollution will be prevented and tackled where possible.

3 By 2020, sustainable agricultural management will be in place to ensure the conservation of biodiversity within the Netherlands. Internationally, pilots will have 


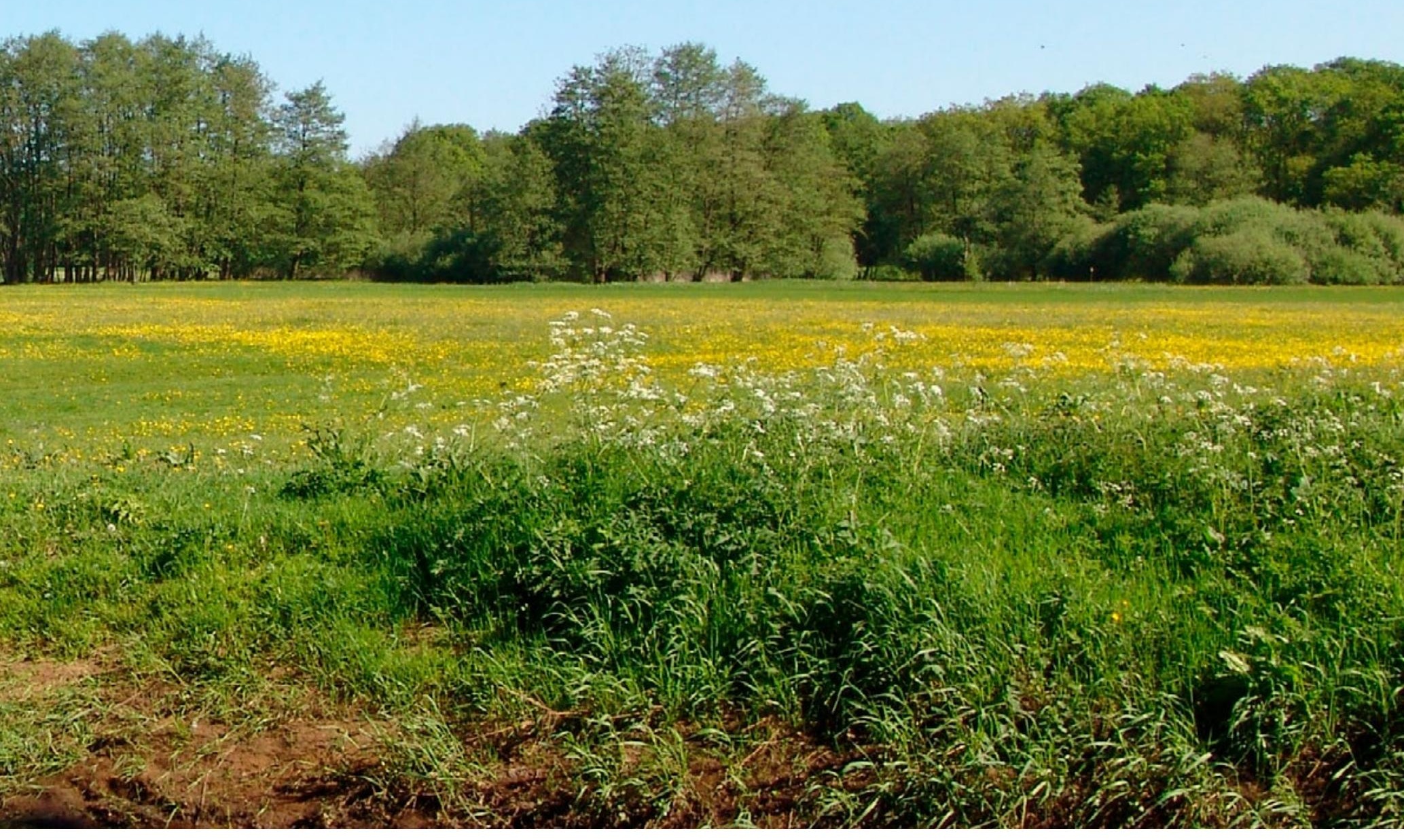

been set up to demonstrate that the private sector can and is willing to contribute to the restoration of ecosystems and that a degraded area can be turned around and transferred into an area of productive and diverse biodiversity with a balanced water system.

4 By 2020, all ecosystem services in the Netherlands will have been identified, along with recognition of their contribution to the economy and this will be incorporated into the decision-making process of government and the private sector.

The Netherlands has deposited the instrument of ratification, acceptance, approval or accession of the Nagoya Protocol and has drawn up a national regulation to implement the Protocol ${ }^{23}$. The measures taken are based on EU Regulation 511/2014 and Implementing Regulation EU 2015/186624. The Dutch Act implementing the Nagoya Protocol has been in force since April 2016. The EU Access and Benefit Sharing Regulation under the Nagoya Protocol

23 https://wetten.overheid.nl/BWBR0037150/2016-04-23

$24 \mathrm{http}: / /$ ec.europa.eu/environment/nature/biodiversity/international/abs/ legislation_en.htm sets out how researchers and companies can obtain access to genetic resources and the traditional knowledge linked to these resources. It also explains how benefits arising from the use of genetic resources and the associated traditional knowledge must be shared with the countries providing these resources ${ }^{25}$.

25 https://www.rijksoverheid.nl/documenten/kamerstukken/2017/06/20/ beantwoording-kamervragen-over-implementatie-nagoya-protocol-engevolgen-voor-nederland 


\section{Main Measures}

Implementation measures taken, assessment of their effectiveness, associated obstacles and scientific and technical needs to achieve national targets

The six main measures of the Kingdom of the Netherlands in Europe are:

1 create new habitat within the national ecological network with the aim of establishing viable species populations;

2 the Nature Conservation Act, an important instrument for species and habitat conservation;

3 subsidies for conservation management measures important for maintaining biodiversity;

4 the Programmatic Approach to Nitrogen (PAN);

5 stimulating sustainable use of natural capital and mainstreaming nature for the benefit of society and the economy;

6 utilising the self-organising capacities of society by stimulating, facilitating and financially support green initiatives.

\section{Information on the main measures implemented} at the national level

\section{II-1 Create new habitat within the national ecological network}

The national ecological network (NEN) includes all $161 \mathrm{EU}$ Natura 2000 sites and is the cornerstone of biodiversity conservation in the Netherlands (Figure 1). The NEN is a network of natural and semi-natural habitat and agricultural land earmarked for conversion to nature. Under the Nature Pact agreement, the provinces will strengthen the NEN by creating at least 80,000 ha of new nature between 2011 and $2027^{26}$.

The NEN was introduced in the 1990 Nature Policy Plan by the Ministry of Agriculture, Nature Management and Fisheries (currently the Ministry of Agriculture, Nature and

26 https://www.rijksoverheid.nl/documenten/kamerstukken/2013/09/18/ kamerbrief-natuurpact
Food Quality). The provinces are now responsible for the implementation of nature policy and realisation of the network. The aim of the NEN is to halt the decline in the area of natural and semi-natural habitat and the loss of biodiversity through the creation of a coherent network of protected areas. This is achieved by enlarging and connecting current nature areas, mainly through the conversion of agricultural land to nature. Having larger natural areas also makes it easier to improve and maintain good water and environmental conditions. Better connectivity between habitats facilitates species migration, enabling them to adapt to climate change.

The land area of the NEN is subject to the 'no, unless' protection regime in the National Policy Strategy for Infrastructure and Spatial Planning ${ }^{27}$, which is enforced via provincial and municipal physical environment plans. The total area of designated land in the NEN amounts to some 750,000 ha. Not represented in this figure are the large water bodies, such as the Wadden Sea, IJsselmeer lake, the delta waters in the southwest of the Netherlands and the territorial waters of the North Sea, which are also part of the NEN. All the provinces have now formally delineated the NEN areas within their territories and made appropriate provisions in their physical environment plans, structural visions and planning regulations ${ }^{28}$.

Any development plan is subject to an environmental impact assessment. The government encourages the inclusion of habitat creation and restoration in development plans by combining nature with other functions, such as climate change adaptation, drinking water supply, redesigning tourism accommodation facilities, urban development, infrastructure investment, flood protection, etc.

27 https://www.rijksoverheid.nl/documenten/rapporten/2012/03/13/ structuurvisie-infrastructuur-en-ruimte

28 https://www.clo.nl/indicatoren/ nl1425-begrenzing-van-het-natuurnetwerk-en-natura-2000-gebieden 


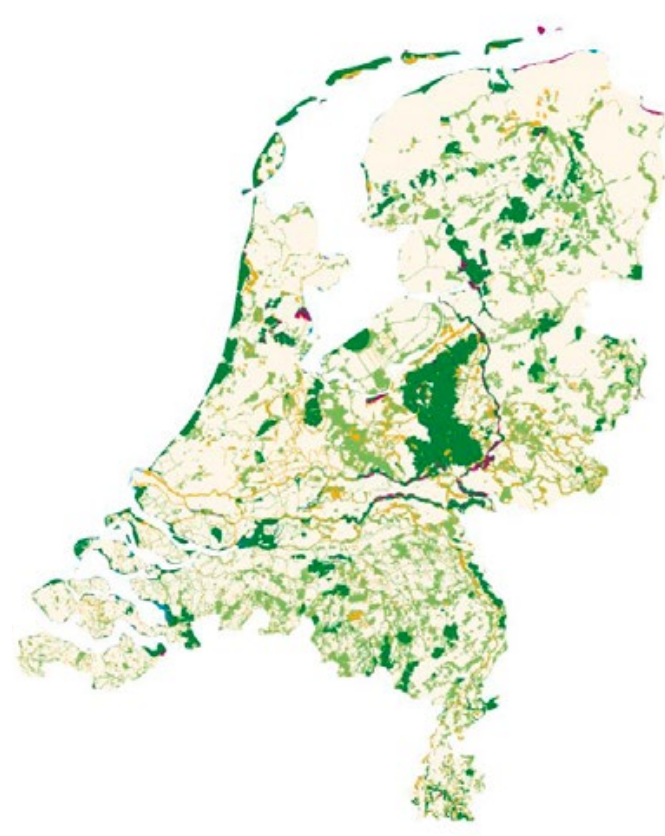

Bron: IPO 2017 (NNN); EZ (Natura 2000); I IM (rijkswateren); Nota Ruimte - VROM en LNV (EHS2005);

\author{
NEN and Natura 2000 sites \\ Land \\ Water
}

NEN

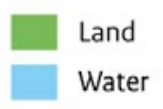

Natura 2000 sites, outside NEN NEN, 2005

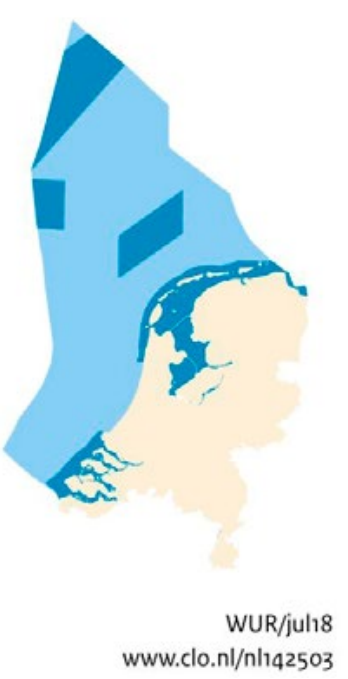

Www.clo.nl/nl142503

Figure 1. Protected areas in the Netherlands

\section{II-2 The Nature Conservation Act}

Nature 2000 sites, forests and wild animals and plants in the Netherlands are protected by the Nature Conservation Act, which took effect on 1 January $2017^{29}$. The obligations of the EU Habitats Directive and the EU Birds Directive have been incorporated into the Nature Conservation Act. The new Act replaces three previous laws: the Nature Conservancy Act 1998, the Flora and Fauna Act 2002 and the Forestry Act 1961. Exemptions or permits for activities that can influence conservation objectives in Natura 2000 sites, protected species or their nesting, rest or feeding places are conditional upon compensation or mitigation measures. The provincial government is the authority responsible for granting exemptions and permits. The codes of conduct drawn up by organisations or trade associations under the Nature Conservation Act state how to prevent or minimise damage to protected plants and animals during the course of recurring management work. Game management units (responsible for the sustainable management of popula-

29 http://wetten.overheid.nl/BWBR0037552/2017-09-01 tions of game and other wildlife in their region) can also obtain exemptions (e.g. for hunting) on the condition that they prepare wildlife management plans to regulate populations that cause damage. The conservation objectives and the necessary conservation measures for Natura 2000 sites are described in a Natura 2000 management plan.

The Act also regulates the trade, transport, possession or processing of animals, plants or eggs from animals taken from the wild in line with the provisions of the Birds and Habitats Directives, the IAS Regulation and CITES.

\section{II-3 Subsidies for conservation management measures}

The Dutch government has decentralised the responsibility for habitat restoration and conservation management to the provinces. The 2013 Nature Pact between the national government and the provinces sets out the aims of nature policy, including conservation management, forestry and improving the agri-environment scheme for farmland 
biodiversity. At the end of 2017 the area of the NEN was almost 624,000 ha, including forests. In 2017 provincial subsidies were granted for the management of $77 \%$ of this area and agri-environment measures were taken on an additional 83,000 ha outside the NEN. ${ }^{30}$

\section{II-4 Programmatic Approach to Nitrogen}

The Programmatic Approach to Nitrogen ${ }^{31}$ (PAN, in Dutch: Programmatische Aanpak Stikstof) is the most important measure for improving environmental conditions necessary for biodiversity protection in the Netherlands. The programme seeks to conserve and restore nitrogensensitive habitats and biodiversity in Natura 2000 areas while permitting economic development that leads to nitrogen deposition and reducing the administrative burden for the initiators of these developments. The PAN relies on nitrogen emission reduction measures and on-site habitat restoration measures. The provinces are now responsible for the implementation of most of these restoration measures.

The PAN took effect from 1 July 2015 and the first period is in force until 2021. A new decision on PAN will then be taken for the period from 1 July 2021 to 1 July 2027. If necessary, there might be a third period. The PAN replaces the appropriate assessments of the implications of nitrogen deposition for the site with respect to its conservation objectives when granting permits under the Nature Conservation Act. The PAN applies to 118 Natura 2000 areas with nitrogen-sensitive nature (the PAN areas).

\section{II-5 Stimulating sustainable use of natural capital}

Policy documents like the Natural Capital Agenda and the letter to parliament on Green Growth ${ }^{32}$ assume that nature and the economy need each other. Dutch government policy is to reduce the impact on biodiversity while at the same time stimulating a more efficient sustainable use of natural capital, for example through public-private collaboration to scale up natural capital approaches, the development of a national natural capital account and use of

30 https://www.bij12.nl/wp-content/uploads/2018/12/ VoortgangsrapportageNatuur_4_provincies_LNV_definitief.pdf 31 https://www.bij12.nl/onderwerpen/programma-aanpak-stikstof/ 32 https://zoek.officielebekendmakingen.nl/kst-33043-14.html the Atlas of Natural Capital ${ }^{33}$. The Atlas of Natural Capital provides information to support and encourage sustainable use of our natural capital. Although it will be difficult for a heavily urbanised country like the Netherlands to reduce its international ecological footprint, serious efforts are underway to limit it as much as possible. Examples include the Sustainable Trade Initiative ${ }^{34}(\mathrm{IDH})$ with the International Finance Corporation and direct agreements between businesses and civil society organisations, such as the national bee strategy ${ }^{35}$ and the Covenant to Promote Sustainable Forest Management ${ }^{36}$. Reducing impacts on local ecosystems will be integrated within such agreements. These agreements pay special attention to the use of certification, such as FSC, and the effectiveness of sustainable use of ecosystems. The Dutch government is also in dialogue with business sectors in the Netherlands to sign up to international corporate social responsibility covenants. These covenants aim to reduce potential risks to human rights, labour rights and environmental protection in international supply chains.

\section{II-6 Utilising the self-organising capacities of society}

The government aims to support green initiatives in society by raising awareness, sharing knowledge and supporting experiments. Examples include the educational and social innovation subsidy schemes Duurzaam Door ${ }^{37}$ and Groen Doen ${ }^{38}$ until 2016, the Green Funds Scheme ${ }^{39}$ (Regeling groen projecten) and Green Deals with businesses and knowledge institutes. The government gives financial support to civil society organisations to raise awareness, monitor and share knowledge and preserve genetic resources (see section III-6).
33 http://www.atlasnatuurlijkkapitaal.nl/en/home

34 https://www.idhsustainabletrade.com/donors/

35 https://www.rijksoverheid.nl/documenten/rapporten/2018/01/22/ nl-pollinator-strategy-bed-breakfast-for-bees

36 https://www.rijksoverheid.nl/documenten/convenanten/2017/03/22/ convenant-bevorderen-duurzaam-bosbeheer

37 https://www.duurzaamdoor.nl/biodiversiteit

38 https://www.greenwish.nl/wp-content/uploads/Evaluatierapport-Groen-enDoen-2015-2016.pdf

39 https://www.rvo.nl/subsidies-regelingen/regeling-groenprojecten 


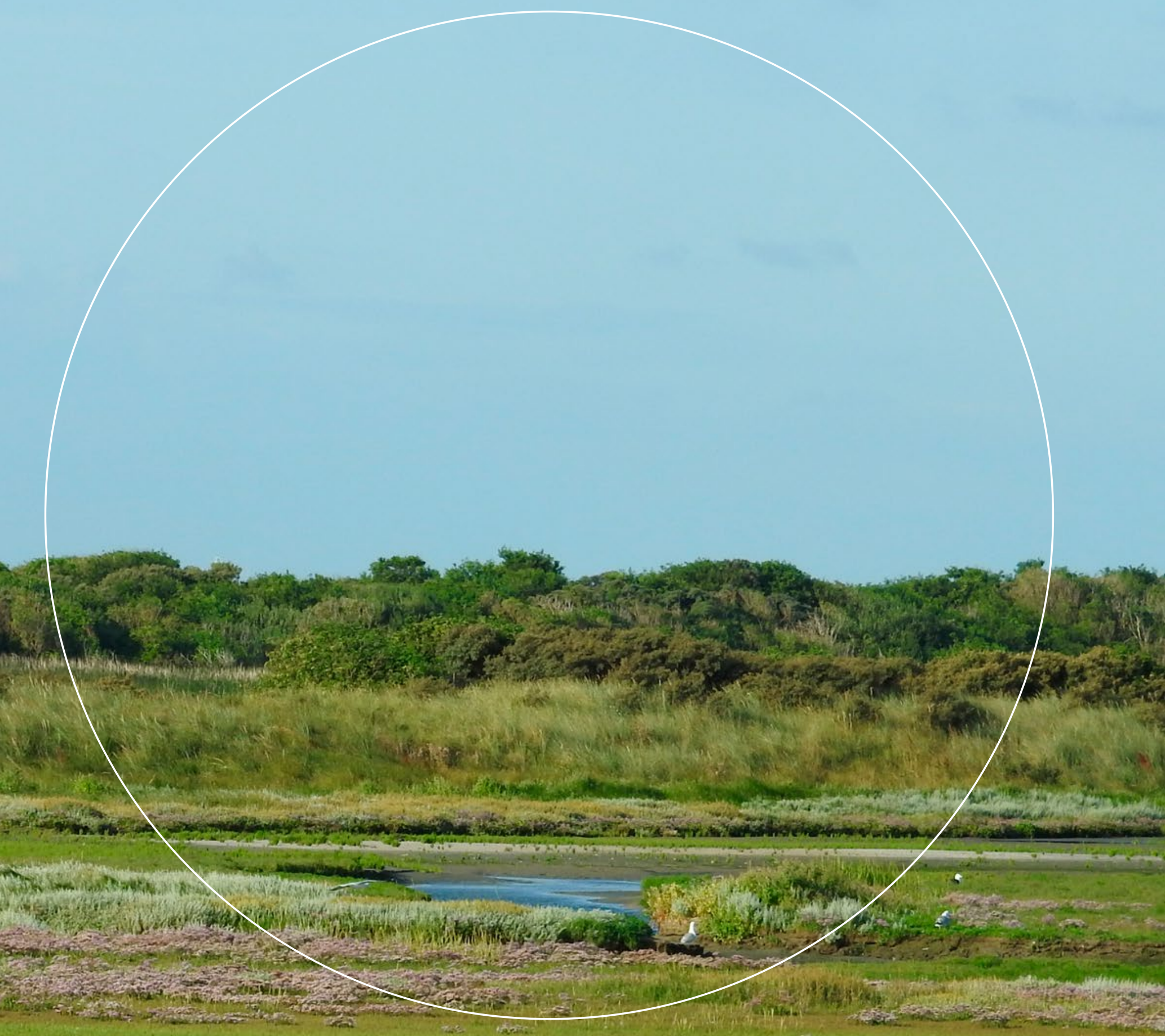

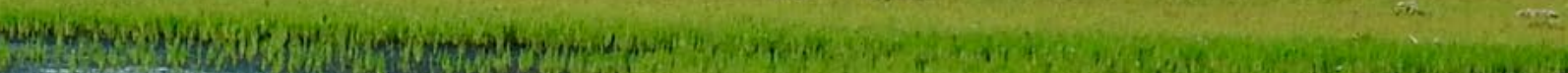

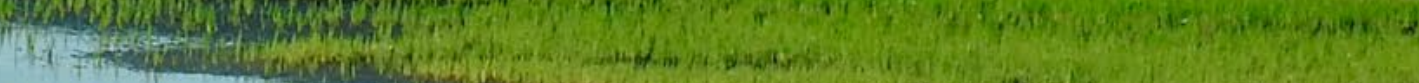

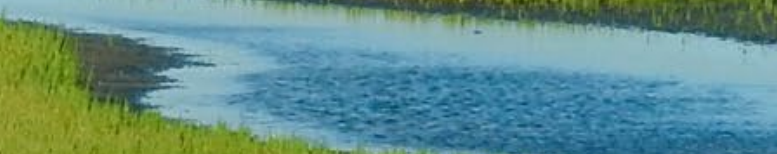

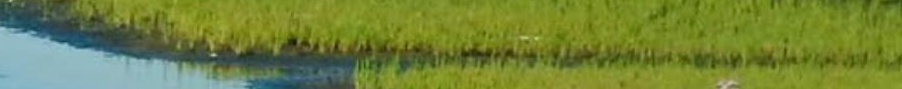

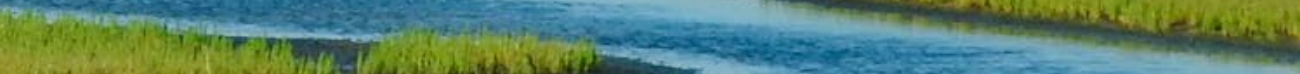

I I I What

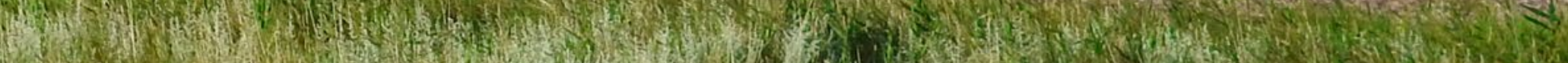

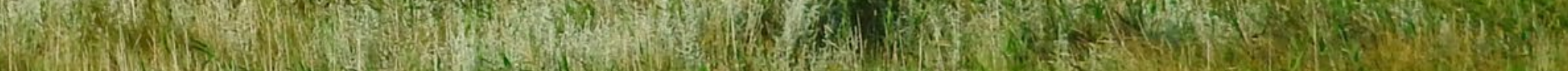

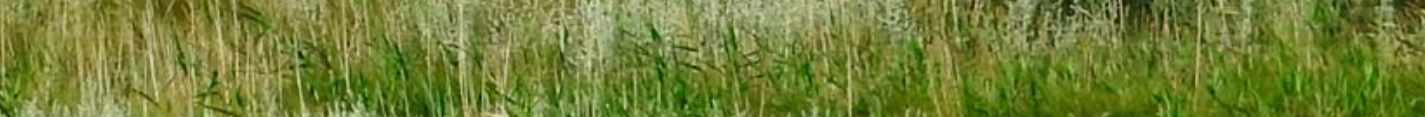

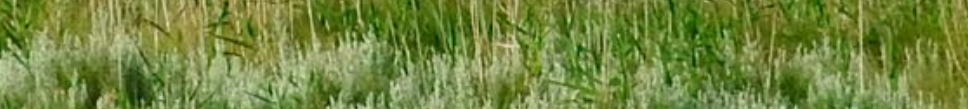

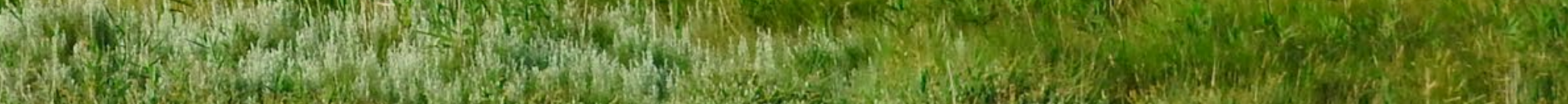

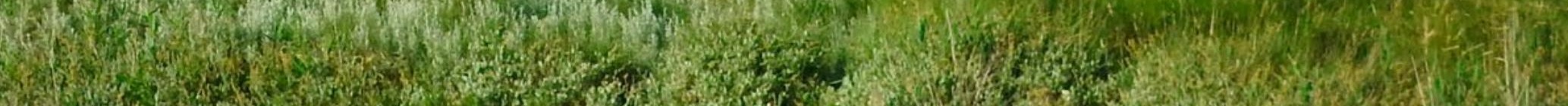

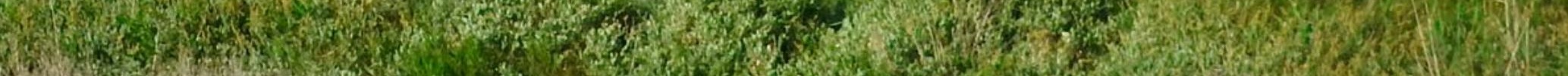

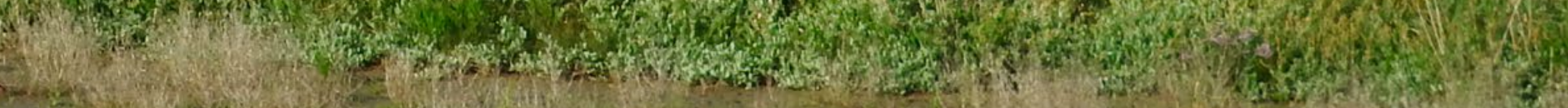




\title{
III Assessment of Main Measures
}

\author{
Assessment of the effectiveness of the implementation measure taken \\ in achieving desired outcomes
}

It is difficult to assess the effectiveness of measures taken as causal relations and interactions between measures, results and targets are very complex. Nevertheless, the results and indicators below show that progress has been made and that the measures are contributing towards several targets, although the targets will not be met in 2020. Based on the results described below, the complex relations, the progress towards the targets and our expert knowledge, we conclude that the measures taken have been partially effective. According to the CBD, partially effective means that "progress towards the stated target has begun, however the complete desired outcome has not yet been achieved. This could be due to time lags between when the measure was taken and when its effects become visible. It could also be due to national circumstances creating delays or challenges to the implementation of the measure. Other possible reasons for a measure being given this assessment are that the measure has not been implemented at the scale necessary or at the appropriate institutional level."

\section{III-1 Create new habitat within the national ecological network}

Realisation of the national ecological network (NEN) has been effective for the creation of new habitat and the mitigation of habitat fragmentation, but is still insufficient in scale to achieve the national targets in 2020.

Development of the NEN began in 1990 and it is still increasing in size. Habitat loss has been halted and reversed, resulting in net gains. Development of the NEN will continue until 2027. The indicators show that considerable progress has been made and that the measure is contributing towards several targets. We therefore conclude that the measure taken has been partially effective.

\section{Habitat creation and protected areas}

In the period 1990-2017 more than 108,000 ha of land were acquired for the realisation of the NEN (Figure 2$)^{40}$. More than 85,000 ha of agricultural land has been converted to nature (Figure 3). Since 2011 the provinces have converted almost 33,000 ha to nature. The total area of Natura 2000 sites in the Netherlands currently stands at around 20,606 square kilometres, which is more than $14 \%$ of the area of land and inland water and more than $23 \%$ of coastal and marine areas (North Sea, Wadden Sea, Oosterschelde and Westerschelde). An additional almost 400,000 ha is nationally designated for conservation measures and protected by a 'no-unless' planning regime. In total, the NEN covers more than $26 \%$ of the land and inland water area.

\section{Fragmentation}

Fragmentation of the NEN by national transport infrastructure (motorways, waterways and railways) is being tackled through the multiannual habitat defragmentation programme (Meerjarenprogramma Ontsnippering, MJPO; BenW 2004). Between 2005 and 2018 no less than 114 (64\%) of the 178 identified infrastructure barriers causing fragmentation were resolved and a further 46 measures were still under construction (Figure 4$)^{41}$. The measures implemented include the construction of green bridges, eco-culverts, wildlife underpasses, wildlife overpasses at tree crown level and hop-overs. Surveys show that most wildlife crossings serve multiple species. Wildlife crossings in combination with wildlife fencing also considerably reduce the number of road kills.

Rivers and streams contain many obstacles to migratory fish species, such as dams, hydro turbines and pumping stations. The Benelux Decision on the free migration of fish (M2009) 42 states that migratory fish species, particularly eel, salmon, sea trout and flounder, must be able to migrate freely in all river basins. The new Benelux Decision

\footnotetext{
40 http://www.clo.nl/en/indicators/ en1307-new-ehs-acquisition-and-development

41 http://www.clo.nl/en/indicators/en2051-barriers-and-fragmentation

42 http://www.benelux.int/files/2913/9230/1235/M_2009_1_NL.pdf
} 


\section{Land acquisition and change of use for new nature}

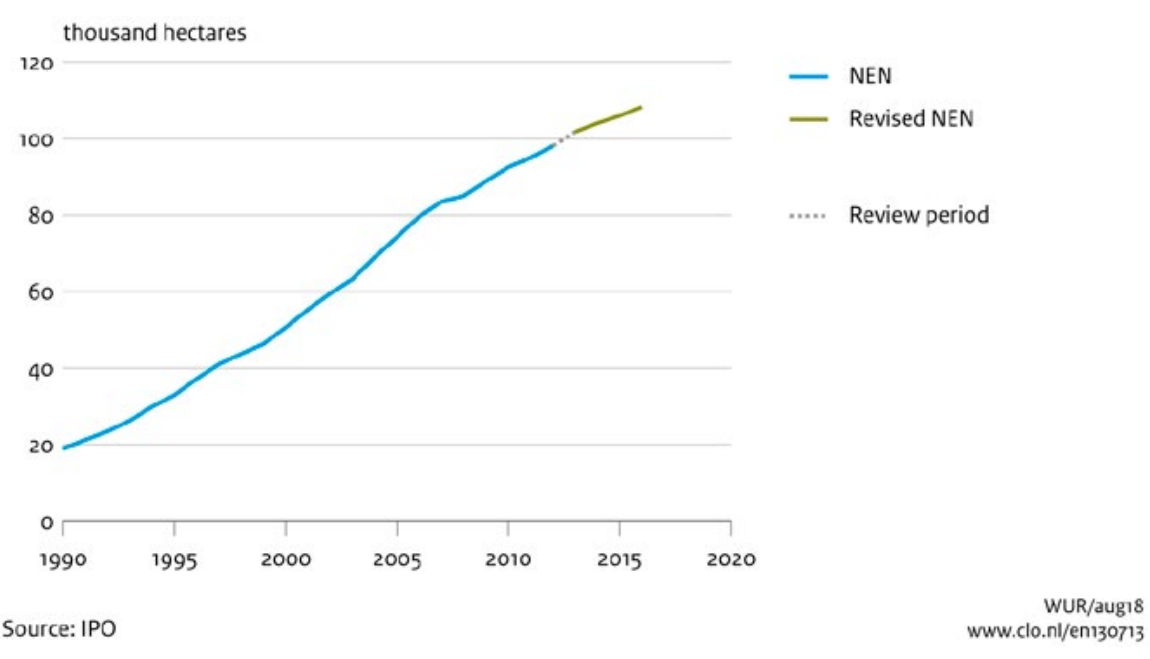

Figure 2. Land acquisition to create new habitat and enlarge and connect nature areas

\section{Conversion to new nature}

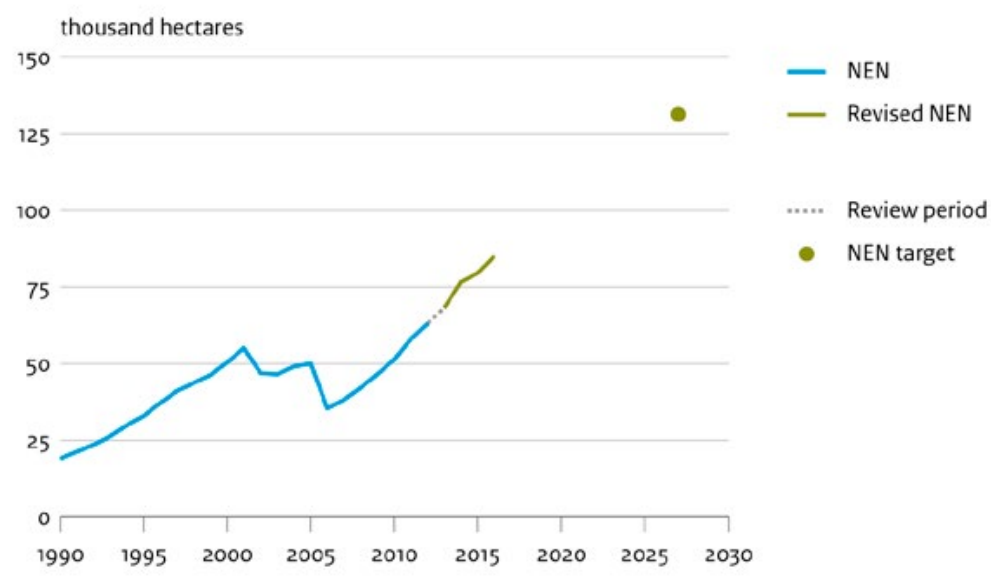

Source: IPO

Figure 3. Habitat created

includes a prioritisation map showing all obstacles to be removed by 2027. Other policy regulations for migratory fish are the European Eel Regulation ${ }^{43}$ (European Union, 2007) and the Water Framework Directive. Many fish passages have already been built. The Rhine and the Meuse rivers have been fully accessible to migratory fish since 2007 thanks to the construction of fish passes at the

43 https://eur-lex.europa.eu/eli/reg/2007/1100/oj larger dams (Figure 5) ${ }^{44}$. Although fish passes have been constructed to enable upstream migration, downstream migration can still be a problem, for example in the Meuse. The Haringvliet sluice gate forms part of an important migration route, as it is the main discharge channel for the Rhine. This barrier was removed in 2018 by the Kierbes/uit ${ }^{45}$ (decision to leave the sluice gates ajar).

44 http://www.clo.nl/en/indicators/en1350-measures-for-migratory-fish

45 https://www.rijkswaterstaat.nl/nieuws/2018/10/kierbesluit-treedt-15november-2018-in-werking.aspx 


\section{Elimination of fragmentation problems caused by national transport infrastructure}

Total

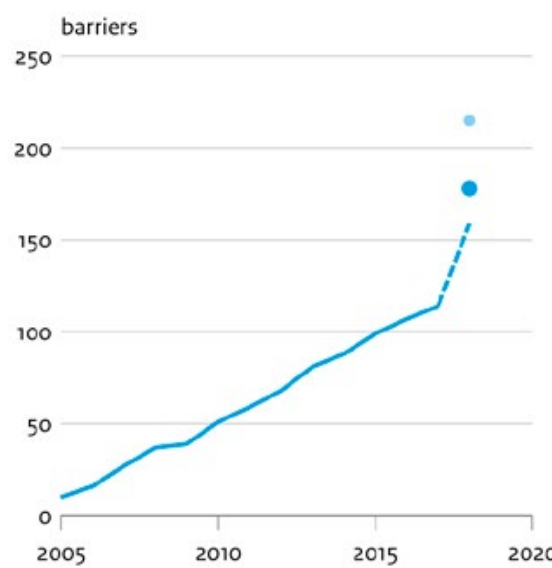

- Realisation

--- MJPO plan

- Target adopted in 2005

- Revised target adopted in 2015

Source: MJPO
Per province, 2017

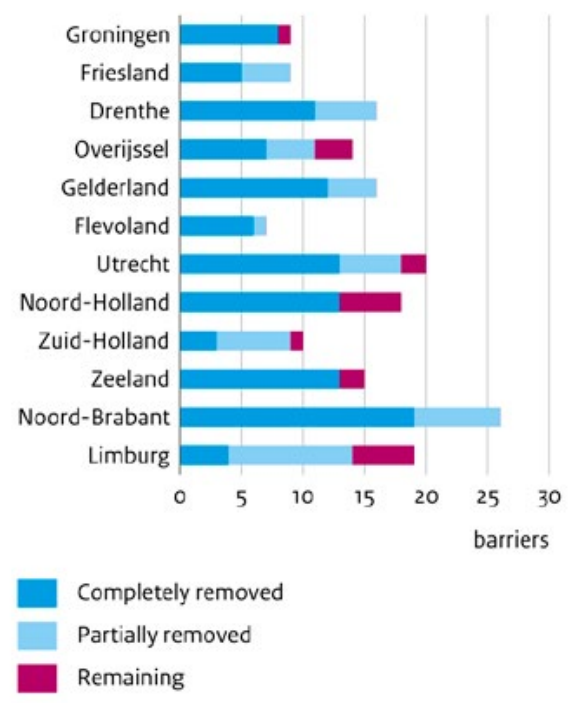

WUR/aug 18 www.clo.nl/en205112

Figure 4. Solved infrastructure barriers causing habitat fragmentation

\section{Fishmigration, 2018}

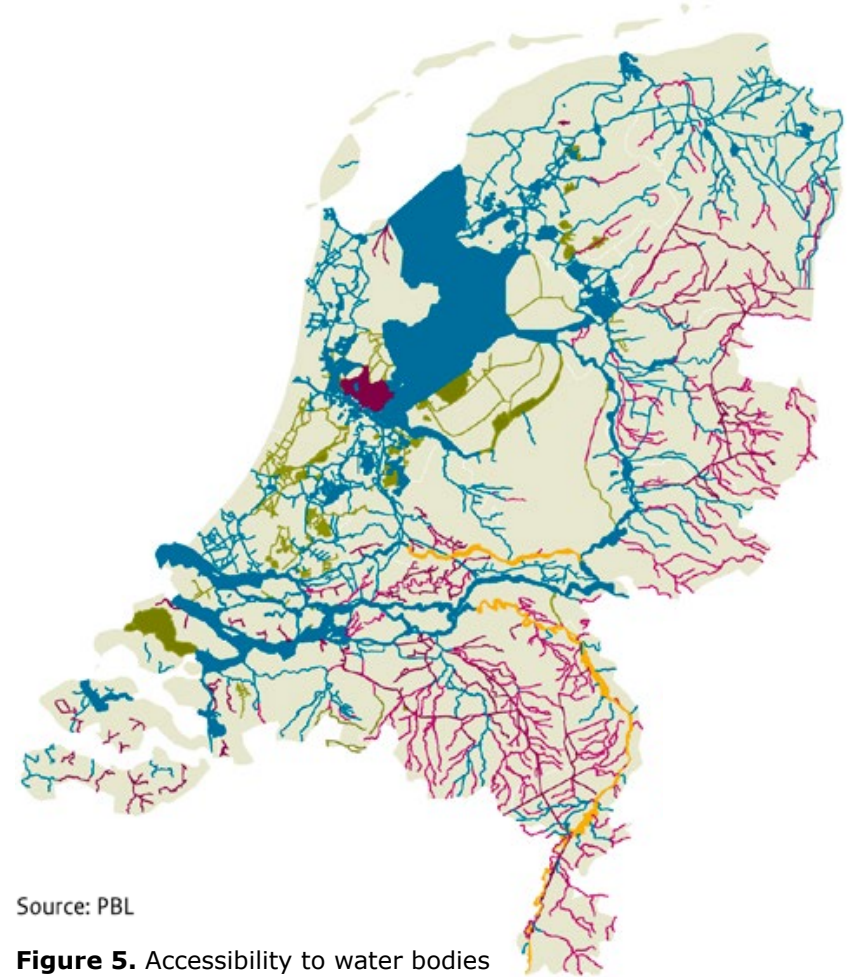

Waterbodies

- Fully accessible, connected to sea

- No barriers, but not connected

- Poorly accessible downstream

- No open connection to sea

Figure 5. Accessibility to water bodies 


\section{Spatial protection regime}

The National Policy Strategy for Infrastructure and Spatial Planning ${ }^{46}$ (SVIR) lays down a 'no, unless' development control regime for the NEN that protects nature within the network against development with negative impacts. Under this regime housing construction within the boundaries of the NEN increased only slightly between 2000 and $2017^{47}$.

\section{Other relevant information}

The creation of the NEN is also an important measure for mitigating the effects of climate change as it creates ecological corridors, for example along rivers and along the coast, through which species can migrate as climate conditions shift northwards, and the impact of extreme weather conditions can be reduced by taking adaptive measures within the NEN.

On 22 March 2018, the Minister of Infrastructure and Water Management presented the evaluation of the Room for the River programme to the House of Representatives ${ }^{48}$. The measures were designed to restore natural riverine processes and improve the ecological, landscape and recreational qualities of the immediate surroundings $^{49}$ (see also section IV-2).

The 'Nature Ambition for the Large Waters: 2050 and beyond' is a strategic vision document on nature in the large waters bodies of the Netherlands in the light of the impacts of climate change ${ }^{50}$. Natural processes have a crucial role in this vision by creating new synergies between urgent flood protection measures and nature conservation, recreation and tourism. This concept is called 'building with nature' or 'eco-engineering'. A striking example is the 'fish migration river' in the Afsluitdijk ${ }^{51}$, an innovative engineering solution which allows fish to migrate between the marine environment of the Wadden Sea and the fresh water of the IJsselmeer while preventing the freshwater body from becoming brackish. The Nature Ambition has been explored in more detail for

46 https://www.rijksoverheid.nl/documenten/rapporten/2012/03/13/ structuurvisie-infrastructuur-en-ruimte

47 http://www.clo.nl/indicatoren/ nl2050-bouwen-in-natuurgebieden-in-de-ecologische-hoofdstructuur

48 http://publicaties.minienm.nl/documenten/ ruimte-voor-de-rivier-oogst-ruimtelijke-kwaliteit

49 http://rijninbeeld.nl/wp-content/uploads/Rijn-en-Beeld-brochure-Irnc.pdf

50 https://www.rijksoverheid.nl/documenten/publicaties/2013/10/31/ beleidsverkenning-natuurambitie-grote-wateren-2050-2010

51 https://www.deafsluitdijk.nl/projecten/vismigratierivier/ large rivers in the Netherlands ${ }^{52}$. Furthermore, Rijkswaterstaat has explored what is necessary to make the nation's large water bodies ecologically sound and future-proof ${ }^{53}$. The result of these studies is a proposal for a package of measures to restore the natural dynamics of the water and the ecological processes that go with it. In early 2018 the water management and nature ministers announced that these measures will be implemented under a 30 year programme to 2050, the 'Programmatic Approach to the Large Water Bodies ${ }^{\prime 54}$.

\section{III-2 The Nature Conservation Act}

Although protected species and habitats are in theory well protected, in practice they are still subject to actual or potential negative impacts from many activities. The populations of many protected species are still declining and the number of invasive alien species is still increasing (see also Aichi Targets 11, 12 and 9). All things considered, we conclude from the results that the measure taken have been partially effective.

\section{Protection of species and habitats}

The presence of vulnerable protected species and habitats are taken into account when assessing applications and issuing permits or exemptions for activities such as construction work, demolishing buildings or felling trees. Compensation and mitigation measures are mandatory when significant negative effects on conservation objectives or protected species are expected. In theory, strict application of these measures should result in no net negative effect on the conservation status of protected species and habitats, but in practice, compensation and mitigation measures for species protection are based on expert knowledge and monitoring is rarely required ${ }^{55}$ (see also appendix 3). Furthermore, control and enforcement is difficult and is a source of ongoing concern.

Permits and exemptions are made public and nature conservation organisations or others may lodge objections

\footnotetext{
52 https://www.rijksoverheid.nl/documenten/publicaties/2017/07/18/ natuurverkenning-grote-rivieren

53 https://www.helpdeskwater.nl/onderwerpen/water-ruimte/ecologie/ programmatische/@178960/factsheets-programma/

54 https://www.helpdeskwater.nl/onderwerpen/water-ruimte/ecologie/ programmatische/

55 http://www.pbl.nl/sites/default/files/cms/publicaties/PBL_2011_ Effectiviteitnatuurwetgeving_555084002.pdf; http://library.wur.nl/WebQuery/ wurpubs/fulltext/365958
} 
if they believe that the ecological (appropriate) assessment or the mandatory measures attached as conditions on the exemption are inadequate. Furthermore, enforcement action may be taken if permit conditions are not complied with.

\section{Invasive alien species}

Policy measures are being implemented to eliminate and control a number of invasive species and prevent their introduction. At the same time, the number of invasive and potentially invasive alien species is still increasing (see also section IV-5).

\section{Other relevant information}

The total area of Natura 2000 sites protected by the Nature Conservation Act in the Netherlands currently stands at 20,606 square kilometres, which is more than $14 \%$ of the area of land and inland water and more than $23 \%$ of coastal and marine areas (North Sea, Wadden Sea, Oosterschelde and Westerschelde). Plans or projects may only be carried out in these sites if mitigation of negative impacts is possible. Nevertheless, if mitigation is not possible and in the absence of alternatives, plans or projects may be carried out for imperative reasons of overriding public interest, but these must be accompanied by compensatory measures to ensure the overall coherence of Natura 2000. This protection by law and in planning ensures that habitat loss can be compensated.

\section{III-3 Subsidies for conservation management measures}

Although the national targets will not be reached, the results and indicators show that progress has been made and the measure is contributing to several targets. All things considered, we conclude from the results that the measure taken has been partially effective, especially for forests and nature. The agri-environment scheme has been revised and it is still too early to expect better results.

\section{Subsidies for conservation management in forests and nature reserves}

All forests in the Netherlands are legally protected and most are sustainably managed. Forest management work is done outside the breeding season. Protected species are surveyed and their habitats are spared during management measures. Management is geared to obtaining a varied forest structure and the presence of sufficient dead wood. Populations of typical forest breeding birds have increased slightly over the last 10 years (Figure 15, section IV-3). The amount of dead wood in forests is also increasing (Figure 16 section IV-3). Subsidies for conservation management measures have been partially effective in achieving the desired outcomes, especially in heath and dune ecosystems (Figure 6), because the effects of management are partially neutralised by other factors, such as inadequate environmental conditions (e.g. due to pollution) (Aichi Targets 8, and measure II-4).

\section{Agri-environment schemes}

Since 1975 the Dutch government has supported biodiversity protection on agricultural land (Relatienota policy) and 'agricultural nature management' remains an important part of Dutch nature policy (see also section I-3). The agri-environment schemes have been evaluated and reconsidered several times and the policy of actively integrating conservation management into intensive farming was found to be not effective enough (Rli, $2013^{56}$ ). Biodiversity on intensively farmed land has decreased dramatically and is still decreasing, despite the efforts taken by many stakeholders to improve the situation (farmland bird index, Figure 7). In response to the Rli report, the subsidy system has been renewed. As a cross-farm approach was expected to be a more flexible and effective way to reverse the decline in farmland biodiversity, a regional collective approach was established for the Agri-Environment Climate Management scheme. To define management priorities, 67 species $^{57}$ listed in the Birds and Habitats Directives were assigned to four types of landscape: Open Grassland; Open Arable Land; Wet Corridors and Dry Corridors. The core of the renewed system is a habitat approach for animal species of international importance on the basis of a collective and area-oriented approach. Although management is not geared to single species, because suitable habitats are beneficial to many species, the habitat requirements of each of the selected 67 farmland species are taken into account.

From 2016 onward an increasing proportion of agrienvironment management has been carried out via the renewed agri-environment scheme (ANLb), with the aim of implementing effective and efficient management in the

56 https://www.rli.nl/publicaties/2013/advies/ onbeperkt-houdbaar?adview =inleiding

57 https://www.bij12.nl/assets/VNBL mei2015 def.pdf 


\section{Living planet index terrestrial and fresh water fauna}

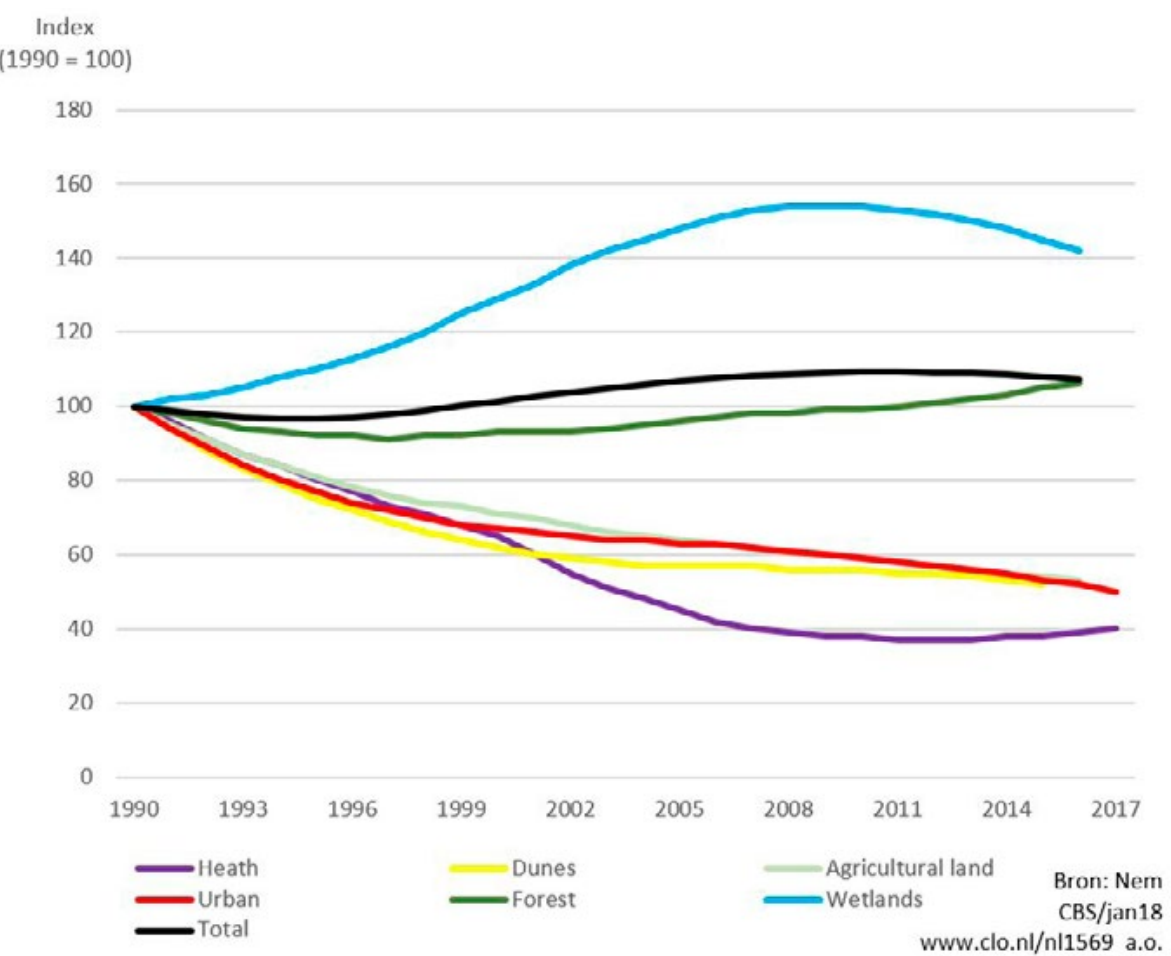

Figure 6. Trends in terrestrial fauna per ecosystem

potentially most promising areas for nature conservation. There are 40 farmers' collectives active nationwide, with more than 8,000 farmers participating ${ }^{58}$. The collectives are largely responsible for registration, allocation of funds, management activities and reporting. An evaluation of the ANLb by Wageningen Environmental Research in $2016^{59}$ shows that the provincial governments and agricultural collectives have concentrated more on promising areas for conservation. Under this agricultural collectives approach, $53 \%$ of the meadow bird management 'light' package and $62 \%-64 \%$ of the meadow bird management 'intensive' package now lie within promising areas. This is a slight improvement on the situation in 2010. In this area-oriented and learning approach the provincial governments and agricultural collectives work with partners, such as research institutes, volunteers and conservation management organisations, to implement the schemes.
Loss of biodiversity on farmland is an observed trend throughout Europe ${ }^{60}$ and the EU common agricultural policy (CAP) for 2014-2020 has shifted its focus to animal welfare and environmental care. The goals of the CAP range from contribution to farm incomes to the sustainable management of natural resources. The EU has earmarked approximately EUR 100 billion and EUR 61 billion of public funding from Member States within the 20142020 multiannual financial framework for rural development, pillar 2 of the CAP61. The Dutch agri-environmental schemes fall under pillar 2. Since 2014 the CAP includes a new direct payment for a compulsory set of 'greening measures', which account for $30 \%$ of the direct payments budget (pillar 1). These measures are intended to make the CAP more effective in delivering its environmental and climate objectives and to ensure the long-term sustainability of EU agriculture. The greening measures comprise crop diversification, maintenance of permanent grassland and Ecological Focus Areas to safeguard and improve

60 https://www.clo.nl/en/indicators/en1479-farmland-birds

61 http://www.europarl.europa.eu/factsheets/en/sheet/110/ second-pillar-of-the-cap-rural-development-policy 


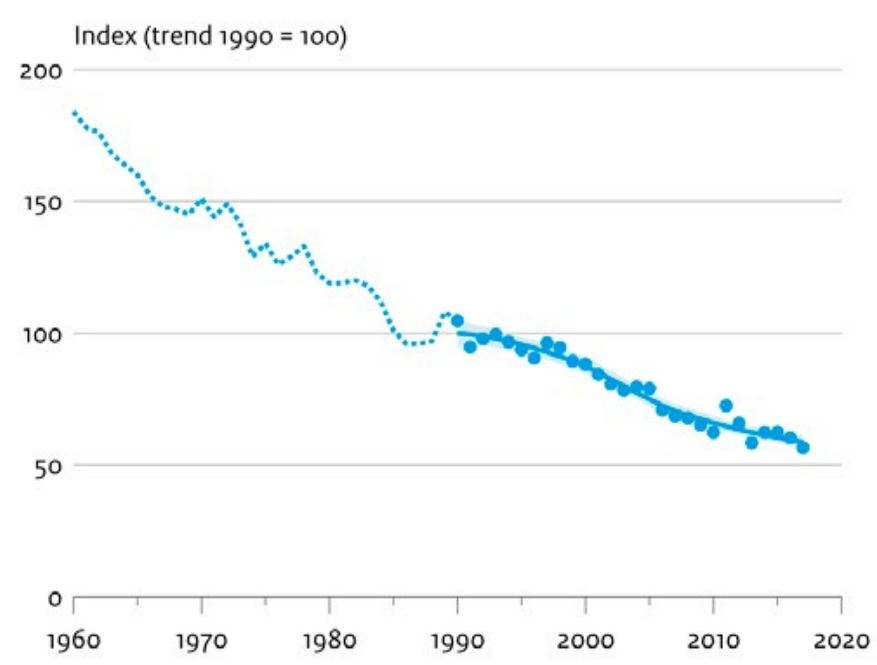

Bron: NEM (Sovon, CBS)

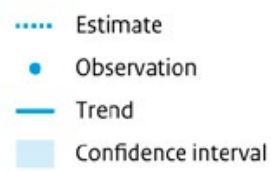

CBS/sep18 www.clo.nl/en147910

Figure 7. Farmland birds index

biodiversity on farms. However, the potential benefits for biodiversity have been evaluated and found to be limited due to the absence of appropriate management requirements or conditions ${ }^{62}$.

\section{Other relevant information}

Landowners, such as farmers, may also receive subsidies to enhance nature quality or stimulate habitat creation on agricultural land. The Quality Impulse Nature and Landscape subsidy scheme ${ }^{63}$ is for landowners who want to make their land suitable for agricultural nature management and for conservation managers who want to further develop and improve the quality of nature. The quality scheme consists of two subsidies: a quality investment subsidy and a subsidy for changing the designated land use. The quality investment subsidy covers measures that make the area suitable for nature conservation or enhance the quality of nature. The subsidy for a change in designated land use compensates for the reduction in the economic value of land converted from agriculture to nature. The area in question must be included in the provincial nature management plan.

62 https://ec.europa.eu/agriculture/sites/agriculture/files/leaflet_en.pdf 63 https://www.bij12.nl/onderwerpen/natuur-en-landschap/subsidiestelselnatuur-en-landschap/kwaliteitsimpuls-investeringen-en-functieverandering/

\section{III-4 Programmatic Approach to Nitrogen (PAN)}

Although the national targets will not be reached, the results show that progress has been made and that the measure is contributing to several targets. All things considered, we conclude from the results that the measure has been partially effective.

\section{Restoration measures}

More than 2,200 ecological restoration measures have been planned for the first PAN period (2015-2021) ${ }^{64}$. The aim of the restoration measures is to make nature more resistant to nitrogen overload. The restoration measures include hydrological measures, management measures and measures for research and monitoring. The latter two do not directly contribute to the restoration of nature, but are necessary to successfully implement the measures. On 31 March 2018, more than 28\% of the restoration measures to be implemented in the first PAN period were completed ${ }^{65}$. Hydrological measures and habitat creation depend on the cooperation of surrounding landowners and may therefor take more time to organise than other

64 https://www.bij12.nl/onderwerpen/programma-aanpak-stikstof/ herstelmaatregelen-pas-in-beeld/

65 https://www.rijksoverheid.nl/documenten/kamerstukken/2018/10/22/ kamerbrief-over-tussenevaluatie-programma-aanpak-stikstof-pas 
Exceedance of critical loads for nitrogen deposition on terrestrial ecosystems

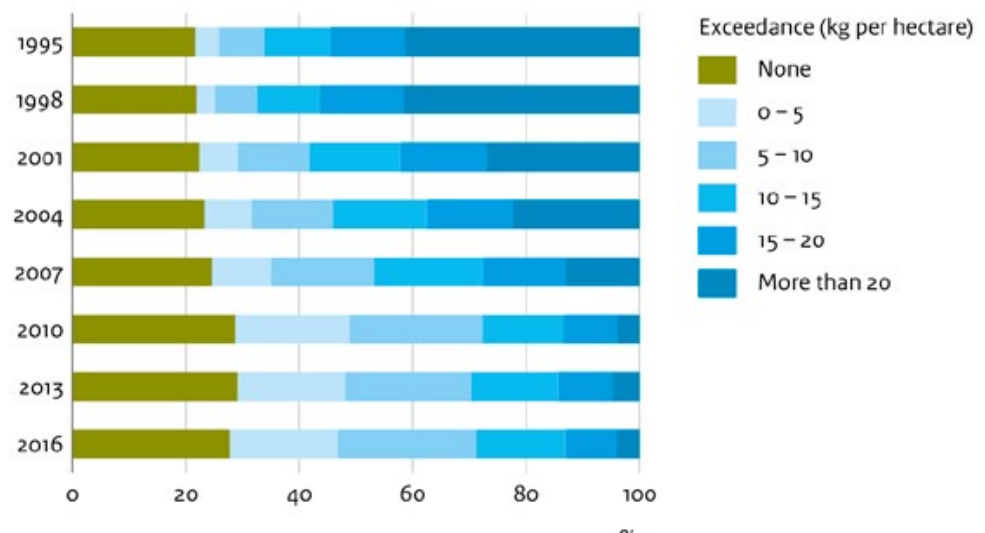

Source: RIVM

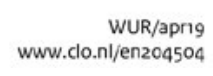

Figure 8. Average exceedance of critical loads for nitrogen deposition

measures. The provincial governments expect that $98 \%$ of the remaining restoration measures will be carried out within the PAN period.

The provinces must ensure that the restoration measures are implemented. Failure to do so will jeopardise longterm development potential because the province or another appropriate authority may only grant permits or exemptions (in advance) for the relevant PAN area if the assessment of the proposed ecological restoration is positive. In some areas drastic measures have to be taken. Sometimes the necessity of these measures is questioned, leading to discussions, a search for alternatives and additional research. The resulting delays raise doubts about the ability to complete these projects before the expiration of the first PAN deadline in $2021^{66}$.

\section{Pollution from excess nutrients}

Nitrogen deposition levels have not decreased since 2010 (Figure 8). Measured ambient ammonia concentrations increased slightly over the period 2005-2016. Reported ammonia emissions in 2014, 2015 and 2016 also increased slightly after years of decline ${ }^{67}$. See also Aichi Targets 8.

66 https://www.rijksoverheid.nl/documenten/rapporten/2018/08/31/ tussenevaluatie-programma-aanpak-stikstof; https://www.pbl.nl/sites/ default/files/cms/publicaties/pbl-2017-lerende-evaluatie-van-hetnatuurpact-1769.pdf

67 https://www.rivm.nl/bibliotheek/rapporten/2018-0117.pdf

\section{Other relevant information}

At the request of the Netherlands Council of State, the Court of Justice of the European Union in Luxembourg examined whether or not the PAN complies with the Habitats Directive. The European Commission stated that an overall assessment such as the PAN does not necessarily conflict with the provisions of the Habitats Directive. However, the European Commission was critical of the fact that permission may be granted for new nitrogen deposition while there is still an overload. According to the European Commission, the Netherlands should first do something to reduce this overload. On 7 November 2018 the European Court of Justice ruled that the PAN may be used when appraising and permitting projects that cause nitrogen deposition in Natura 2000 sites, but only under strict conditions, including the requirement for a scientific qualitative assessment ${ }^{68}$. It was up to the Administrative Law Division of the Council of State to assess whether the PAN meets these conditions. They decided the PAN may not be used for giving permission for activities that emit nitrogen ${ }^{69}$.
68 https://europadecentraal.nl/

europees-hof-van-justitie-pas-alleen-onder-strenge-voorwaarden-verenigbaarmet-de-habitatrichtlijn/

69 https://www.raadvanstate.nl/actueel/nieuws/@115651/pas-mag/ 


\section{III-5 Stimulating sustainable use of natural capital}

An increasing number of people and businesses are becoming involved in actions for conserving and increasing biodiversity. However, not all use of and trade in natural capital is sustainable yet (see Aichi Targets $4,6,7$ ). Although, it is difficult to assess whether or not the measures taken have been effective, the results show that progress has been made and the measures are contributing to several national targets. All things considered, we conclude from the results that the measures taken have been partially effective.

\section{Public-private collaboration to scale up natural capital approaches}

The government of the Netherlands is exploring possible joint actions with private partners, such as the Dutch employers' federation VNO-NCW, the Royal Netherlands Institute of Chartered Accountants NBA, CSR Netherlands and IUCN Netherlands, to scale up natural capital approaches, in particular the Natural Capital Protocol developed by the Natural Capital Coalition. Actions include:

- implementing natural capital approaches in three sectors: agri-food, construction and chemicals;

- developing an online matchmaking and community platform for entrepreneurs working towards a sustainable balance for their business processes, biodiversity and ecosystems;70

- support to IUCN Netherlands for developing and maintaining a community of science for natural capital and the One Planet Thinking initiative to promote the development and adoption of science-based targets by private players;

- support to the finance community for developing smart and responsible financing solutions.71

\section{Natural Capital Account for the Netherlands}

The Dutch ministries of Agriculture, Nature \& Food Quality and Infrastructure \& Water Management have asked Statistics Netherlands (CBS) and Wageningen University and Research (WUR) to develop a national natural capital account based on the UN SEEA EEA framework ${ }^{72}$. A first full account will be ready in 2019 .

\section{Atlas of Natural Capital}

One of the actions of the Natural Capital Agenda is the development of the digital Atlas of Natural Capital (ANK) in the Netherlands. ${ }^{73}$ The Atlas of Natural Capital is an initiative of the former Dutch Ministry of Infrastructure and the Environment and was produced in association with research institutes Deltares, Wageningen Environmental Research, Wageningen Economic Research and the National; Institute for Public Health and the Environment (RIVM). The Atlas provides information and tools to help map our natural capital, use it sustainably and find appropriate solutions, especially for the long term. The Atlas contains information about natural capital, ecosystem services and related concepts, and inspirational examples. The maps include information that can be used when taking decisions that affect the human environment at site level. Companies can use the information to make their operations more sustainable and in their corporate social responsibility reporting. The ecosystem services and stocks are defined in accordance with the European Union's CICES classification (Common International Classification of Ecosystem Services), which was developed to provide an internationally harmonised nomenclature. It enables ecosystem services to be mapped Europewide and is thus also a step towards implementation of the European Biodiversity Strategy. The Atlas is a work in progress.

\section{Sustainable Trade Initiative (IDH)}

The government of the Netherlands supports IDH in accelerating market transformation towards sustainable supply chains ${ }^{74}$. Besides providing finance, the Netherlands is an active partner through its embassy network and international diplomacy. The Ministry of Foreign Affairs has granted IDH an additional EUR 100 million for the period 2015-2020 to co-fund private sector investments in sustainable market transformation in 11 commodity sectors. The Dutch government has granted IDH EUR 20 million for the period 2015-2020 to pilot a landscape approach in six resource vulnerable landscapes. IDH aims to reduce deforestation and forest degradation on 5.4 million ha of land as a direct result of the IDH interventions. According to the first assessment report, little is known about whether or not certification initiatives (FSC, RSPO, RTRS) have much impact in terms of overall mitigation of deforestation ${ }^{75}$. The

\footnotetext{
73 https://www.atlasnatuurlijkkapitaal.nl/

74 https://www.idhsustainabletrade.com/donors/

75 https://www.idhsustainabletrade.com/uploaded/2017/05/170407-IDHevaluation-first-assessment-report.pdf

0 https://naturalcapital futureproof.community/

71 https://naturalcapital.futureproof.community/cirkels/ greening-finance-community

72 https://www.wur.nl/en/project/Ecosystem-Accounting.htm
} 
authors of the report think the IDH approach could be effective in mitigating deforestation, but little evidence is as yet available on the impact of the approach on sustainable landscape management, forest conservation and restoration as this is still a new initiative within IDH. An important step in scaling this initiative up was the signing by several EU Member States of the Amsterdam Declaration, committing them to sustainable sourcing of the 'deforestation commodities' palm oil, soy and cocoa.

\section{National bee strategy 22 January 2018}

The impacts of pesticides on nature, especially on bees, is currently attracting much attention. More than half of all wild bee species in the Netherlands are on the national Red List. The Natural Capital Agenda outlines some concrete actions to protect and conserve bees. The Dutch government provides incentives to farmers to create arable field margins with wild flowers specially designed to facilitate functional agro-biodiversity, stimulates the use of non-chemical crop protection methods and requires farmers to use emission reduction techniques. The government and 42 other social partners have drawn up and signed a national bee strategy ${ }^{76}$ to protect and conserve bees and other pollinators in 2030. The strategy contains some 80 initiatives from the partners to improve biodiversity, improving the relationship between agriculture and nature and improve the health of bees.

\section{Promoting Sustainable Forest Management Agreement 22 March 2017}

This agreement ${ }^{77}$ is a follow-up to the Green Deal Promoting Sustainable Forest Management that was implemented in the period 2013-2015. It embodies the undiminished commitment of the Parties (government, timber sector, civil society organisations and knowledge institutions) to promote sustainably managed forests worldwide and their ambition to implement corporate social responsibility throughout the international timber value chain.

\section{FLEGT and VPA policies implemented}

Improved law enforcement as promoted in the EU FLEGT (Forest Law Enforcement, Governance and Trade) Action Plan has been evaluated as a relevant and innovative

76 https://www.rijksoverheid.nl/documenten/rapporten/2018/01/22/ nl-pollinator-strategy-bed-breakfast-for-bees

77 https://www.rijksoverheid.nl/documenten/convenanten/2017/03/22/ convenant-bevorderen-duurzaam-bosbeheer response to the challenge of unlawful logging ${ }^{78}$. Policies banning illegally sourced timber from the Dutch market, especially the tropics, are in place. Together with capacity building on forest governance via Voluntary Partnership Agreements (VPAs), this may help to reduce global biodiversity loss from deforestation. The Netherlands Food and Consumer Product Safety Authority (NVWA) checks whether or not timber complies with EU rules, including on trade in illegally logged timber ${ }^{79}$. Market participants must give guarantees of legal origin. The NVWA can and has imposed penalty charges on companies that import illegally logged timber into the European market.

\section{Other relevant information}

The European Union is responsible for policies on managing marine living resources in Europe and elsewhere where European fisheries operate. The new CFP80, which entered into force in 2014, applies to fishing by EU vessels in international waters and in territorial waters of third countries, unless agreements with the third country state otherwise. It contains an obligation to land all catches of regulated fish species and prohibits discards. In addition, the Dutch government stimulates technical and other innovations for sustainable fisheries with fewer discards and the development of management plans for marine Natura 2000 sites. Important examples of research and innovation are the transition from mussel seed fishing to mussel seed capture installations and the transition from traditional beam trawl fishing to electric pulse fishing ${ }^{81}$. Parts of the Natura 2000 areas (North Sea Coastal Zone and the Vlakte van Raan) are closed for forms of fishing that have an impact on bottom life or which can disturb marine mammals and birds. The measures related to the European Marine Strategy Framework Directive are currently being implemented in order to conserve marine biodiversity ${ }^{82}$. The target of the framework is to reach good environmental status by 2020 .

\footnotetext{
78 http://ec.europa.eu/environment/forests/illegal_logging.htm

79 https://www.nvwa.nl/onderwerpen/import-van-hout-en-houtproducten-flegt/ over-flegt

80 https://ec.europa.eu/fisheries/cfp en

81 https://www.groenkennisnet.nl/nl/groenkennisnet/dossier/dossier-pulskor. htm; https://www.groenkennisnet.nl/nl/groenkennisnet/show/dossiermosselinnovatie.htm

82 https://www.noordzeeloket.nl/beleid/europese/nationaal-niveau/marienestrategie/; https://www.informatiehuismarien.nl/krm/
} 


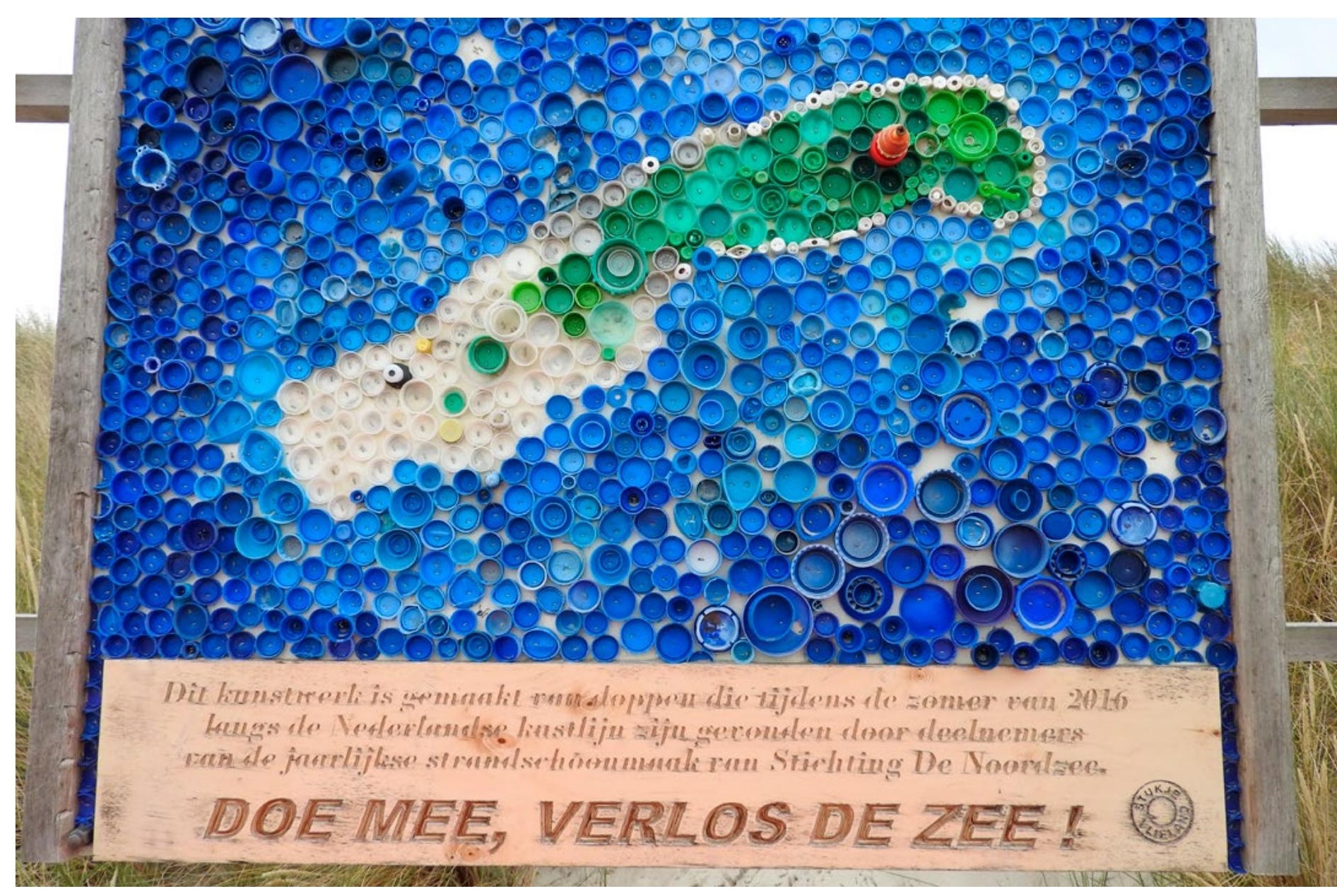

\section{III-6 Utilising the self-organising capacities of society}

An increasing number of people and businesses are becoming involved in actions for conserving and increasing biodiversity. Awareness in society of the need to conserve nature is relatively high and ecological data and knowledge is effectively shared and used, but the conservation of genetic diversity for animal breeds is still a concern (see Aichi Targets 1, 13, 19). Although, it is difficult to assess whether or not the measures taken have been effective, the results show that progress has been made and the measures are contributing to several targets. All things considered, we conclude from the results that the measures taken have been partially effective.

\section{Progress in Sustainability programme (Duurzaam Door)}

The national government works with local and regional governments, entrepreneurs and educational, research and civil society organisations on the transition to a greener and more sustainable economy. The programme ${ }^{\mathbf{8 3}}$ aims to generate knowledge, raise awareness and inspire attitudes to promote progress towards a sustainable economy and green economic growth. The main results of the programme are: setting up projects and cooperation agreements with multi-stakeholder groups, guiding regional sustainability networks, publications and many meetings, seminars and conferences. The programme has a budget of EUR 4 million per year and other parties are expected to contribute financially as well. The programme consists of nine themes: biodiversity, circular economy, energy, food, water, education, regional networks, the new Environment and Planning Act and social innovation. These themes are bound to transition processes like sustainable production and consumption, socially accepted enterprises, educational issues and integrated development. The biodiversity team has organised and initiated regional meetings, national parks sustainability networks, collaboration between garden centres and centres for nature and environmental education, and biodiversity on business parks.

\section{Support voluntary work 'Groen Doen' (Doing Green)}

Groen Doen ${ }^{\mathbf{8 4}}$ was a Ministry of Economic Affairs subsidy scheme that ran until the end of 2016 . The scheme stimulated and developed volunteer work in nature and

84 https://www.greenwish.nl/wp-content/uploads/Evaluatierapport-Groen-enDoen-2015-2016.pdf 


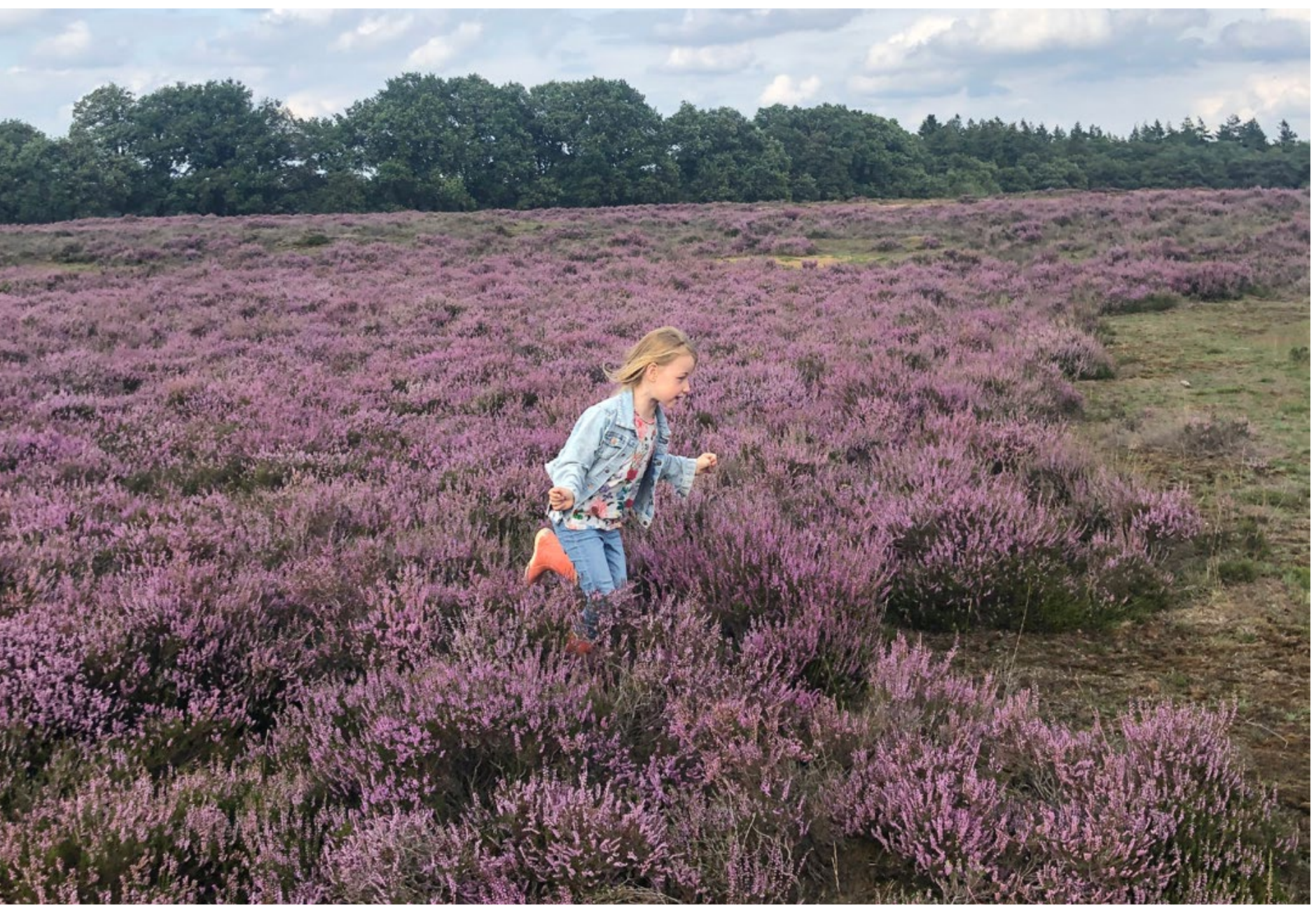

landscape management. In three subsidy rounds, 2,155 vouchers worth EUR 1,000 were awarded in a special, low-threshold way suited to volunteers. In the third round, for 2015-2016, there were 795 vouchers. The vouchers could be used for training to improve their volunteer work and on working more safely, or to organise a training course and offer it to others for free.

\section{Green Funds Scheme (Regeling groenprojecten)}

This scheme aims to promote investments that are in the interest of protecting the environment, including nature and forests. Since 1994, the Green Funds Scheme ${ }^{85}$ has made it easier for banks to provide loans to project initiators with projects that benefit the environmental and nature policy. These loans are made from private savings and investment funds in green banks and green funds.

The private investors receive a tax benefit on these savings and investment funds. From the start of the scheme in 1994 until 1 January 2017, 9,665 green certificates were issued for a total amount of almost EUR 17 billion. Almost EUR 11 million of this went to 16 forest projects (IENM/BSK-2017/267391).

\section{Green Deals}

The Dutch government supports sustainable economic growth by stimulating sustainable innovation. The Green Deal approach ${ }^{86}$ in the Netherlands is low-threshold way for companies, other stakeholder organisations, local and regional governments and interest groups to work with national government on green growth and social issues. The aim is to remove barriers to sustainable initiatives starting up and to accelerate this process where possible. A Green Deal is a mutual agreement or covenant under private law between a coalition of companies, civil society organisations and local and regional governments. The deal defines the innovative initiative, the actions and the input by the participants involved as clearly as possible. Green Deals can be agreed in nine topic areas: energy, the biobased economy, mobility, water, food, biodiversity, resources, construction and climate. In the period between 2011 and 2018, 41 Green Deals for biodiversity were agreed in the Netherlands and presented on the website (per 1 May 2018), involving about 200 participating parties in total.

\section{Raising awareness}

The government gives financial support to social organisa- 
tions to raise awareness. The government has entered into a covenant ${ }^{87}$ with Staatsbosbeheer (a government related conservation management agency) to improve social involvement. Staatsbosbeheer is the largest conservation management organisation in the Netherlands and plays a social role in many different forms ${ }^{88}$. It organises many activities for nature education. For example, over the years 115,000 children have planted trees on Tree Celebration Day, 6,000 children are active in the 'nature wise' programme, and the organisation manages 47 forest playgrounds. Staatsbosbeheer offers work places for offenders that have to do community service and for people with disabilities or who have other difficulties finding a job.

The Institute for Nature Education (IVN) is the largest organisation for nature education in the Netherlands and is subsidised by the national and provincial governments. IVN aims to bring nature closer to people so that they will take better care of it. This contributes to a sustainable society and to the individual health and wellbeing of people. The organisation has 170 local departments, 120 professionals and thousands of volunteers. They organise many excursions, courses, hikes, exhibitions, etc. In 2016 IVN brought 500,000 people, including 100,000 children, into deeper contact with nature ${ }^{89}$.

\section{Monitoring \& knowledge sharing}

The government gives financial support to social organisations for monitoring and sharing knowledge. The Netherlands has a long history of ecological monitoring. The Ecological Monitoring Network ${ }^{90}$ (NEM), set up in 1999 , is a joint initiative by government organisations for monitoring nature in the Netherlands. It aims to collect data that meets the needs of government and monitors trends in nearly all species groups relevant to nature policy. As such, the NEM can be considered to be the backbone of the ecological and wildlife monitoring system in the Netherlands. The NEM mainly commissions private data-collecting organisations (particuliere gegevensbeherende organisaties, PGOs) to carry out the monitoring schemes and is therefore a well-established example of citizen science. The NEM monitoring protocols are standardised in cooperation with Statistics Netherlands (CBS).

87 https://www.staatsbosbeheer.nl/over-staatsbosbeheer/organisatie convenant-staatsbosbeheer-maatschappelijke-onderneming-2014.pdf

88 https://www.staatsbosbeheer.nl/over-staatsbosbeheer/maatschappelijk

89 https://www.ivn.nl/over-ivn/ivn-jaarverslagen

90 http://www.netwerkecologischemonitoring.nl/
CBS is also responsible for data analysis, which strongly improves the statistical reliability of the reported status and trends in Habitats Directive and Birds Directive species in the Netherlands. In addition to the standardised monitoring data, the NEM increasingly uses less standardised data from other sources. The amount of such opportunistic data is increasing rapidly due to easily accessible websites (waarneming.nl \& telmee. $\mathrm{nl}$ ) and apps on mobile phones. New statistical modelling by CBS make these data suitable for monitoring purposes.

The National Database Flora and Fauna (NDFF) ${ }^{91}$, established in 2007, can be considered to be a data warehouse containing the data on plants and animals collected by PGOs, other organisations and volunteers in the past. All data entering the NDFF are validated. In March 2017 it contained a total of 117.5 million observations of species, mostly of birds (ca 50\%), plants and butterflies. Almost $40 \%$ of these observations come from species collecting organisations, just under $40 \%$ are from the website waarneming. $\mathrm{nl}$ and more than $20 \%$ are from other organisations. The number of voluntary observers using this website is increasing. The database is used by national government, municipalities, provinces, districts, conservationists, construction industries and others.

\section{Support for management of genetic resources} The Dutch government gives financial support to the Centre for Genetic Resources in the Netherlands ${ }^{92}$ (CGN) and subsidises the Dutch Rare Breed Survival Trust ${ }^{93}$ (SZH). The trust was founded in 1976 in response to the diminishing variety of traditional breeds, of which some were already threatened by extinction at that point. The trust makes an effort to raise awareness and exchanges knowledge and organises actions to maintain native breeds. CGN was founded in 1985 and is dedicated to preserving genetic diversity in food crops. It has been charged with a role in animal conservation since 1999 and conserving woody plant genetic resources since 2002 . CGN manages ex situ collections (outside the farm and nature) of vegetable and animal genetic resources and helps Staatsbosbeheer, breed societies and farmers to manage their genetic sources. CGN also provides policy support to the Dutch government and is national focal point for Access and Benefit Sharing (ABS).

\footnotetext{
91 https://www.ndff.nl/

92 https://www.wur.nl/en/Research-Results/Statutory-research-tasks/ Centre-for-Genetic-Resources-the-Netherlands-1.htm

93 http://szh.nl/
} 


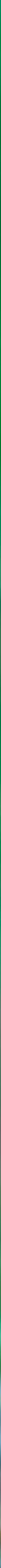

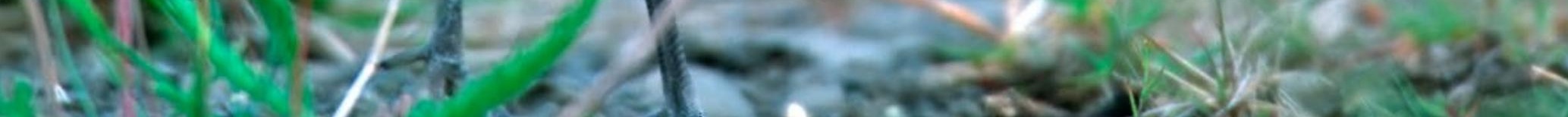

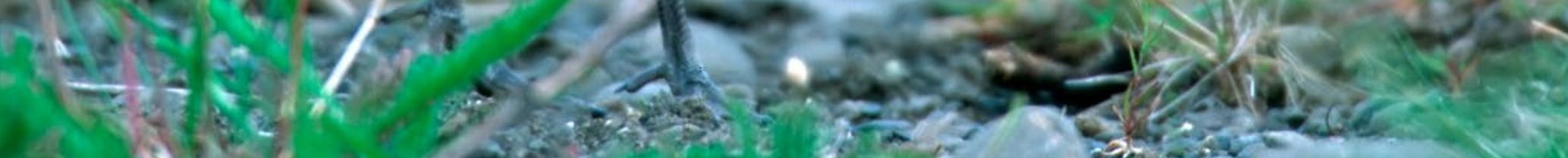
and $y=-x=$ 


\section{Assessment of National Targets}

Progress towards national targets

The progress made towards national targets was determined from available assessments, available indicators and expert judgement based on the estimated level of confidence and monitoring related to the target (Appendix 2).

\section{IV-1 By 2020, the assessments of species and habitats protected by EU nature law show better conservation or a secure status for $100 \%$ more habitats and $50 \%$ more species}

In the previous period the trends in most species and habitats were stable or improving. It is unclear whether or not progress is sufficient to reach the target in 2020. A new assessment of the Birds and Habitats Directive is planned in 2019.

The Netherlands fully implements the EU Habitats and Birds Directives to preserve biodiversity by protecting wild flora and fauna and their habitats. The Member States designate Special Protection Areas (Natura 2000 sites) and protect plant and animal species and habitat types listed in the Annexes to the Directives. In the Netherlands most Natura 2000 sites are fully included within the boundaries of the national ecological network (NEN), which offers protection for additional habitats for species conservation. Many measures have been taken (see section II) to create and restore habitats, reduce fragmentation and improve environmental conditions, both in and outside the NEN. The effects of these measures are reported to the European Commission every six years in an assessment of the conservation status of the habitat types and/or species that are listed in the Annexes to the Habitats and Birds Directives. The latest assessment (2013) showed that the measures are still not sufficient: only $23 \%$ of the listed species and $4 \%$ of the listed habitat types in the Habitats Directive had a favourable conservation status (Figure 9); the remaining species and habitats were considered unfavourable-inadequate or unfavoura- ble-bad. The EU assessment reporting format includes changes and trends in the conservation status of species and habitat types with an unfavourable status. In the Netherlands, $10 \%$ of the habitat types with an unfavourable conservation status have shown an improvement (Figure 10), but at the same time the status of almost $27 \%$ of the habitat types in the Netherlands has deteriorated. The Habitats Directive species show a more positive trend. A little more than $40 \%$ of the species with an unfavourable status have shown improvement and a little more than $11 \%$ deteriorated. The population trends of Birds Directive species in the Netherlands for the period 2001-2012 were variable: the situation of 39\% of the breeding birds has improved, but the situation of $37 \%$ of the breeding birds has deteriorated.

Other indicators of species and habitats also show an improvement: very small improvement in the status of Red List species (RLI) ${ }^{94}$, an increase in population size of characteristic species from ecosystems (LPI) ${ }^{95}$ and an improvement in biological water quality ${ }^{96}$ (see also Aichi Targets 12).

\section{IV-2 By 2020, ecosystems and their services are maintained and enhanced by establishing green infrastructure and restoring at least $15 \%$ of degraded ecosystems}

Coastal protection by sand dunes and water purification by the same dunes are just two of the essential ecosystem services that are already well safeguarded in the Netherlands ${ }^{97}$. Despite the current focus on essential ecosystem services in the Netherlands, the analysis and

\footnotetext{
94 http://www.clo.nl/en/indicators/en1521-red-list-indicator

95 http://www.clo.nl/en/indicators/ en1569-living-planet-index-for-the-netherlands

$96 \mathrm{http}: / / w w w . c l o . n l /$ indicatoren/ nl1420-krw-biologische-kwaliteit-oppervlaktewater

97 Van der Zee et al., 2016: http://library.wur.nl/WebQuery/wurpubs/ fulltext/378969
} 
Conservation status Habitats Directive (HD) 2007 - 2012

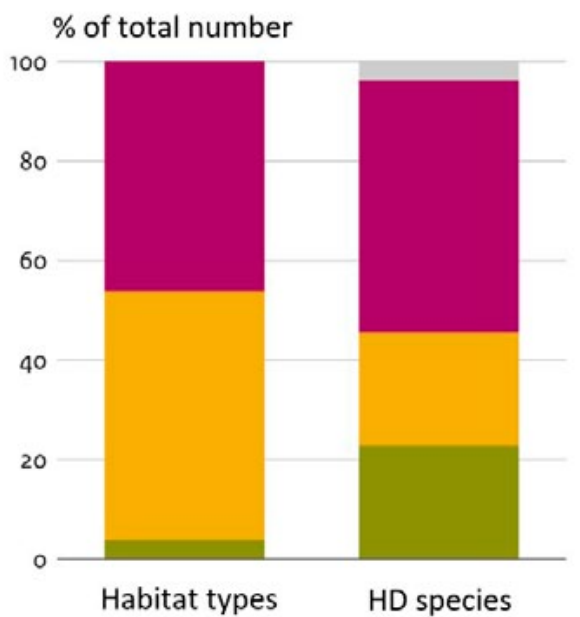

\section{Unknown}

Unfavourable - bad

Unfavourable - inadequate

Favourable
Population trend Birds Directive (BD)

2001 - 2012

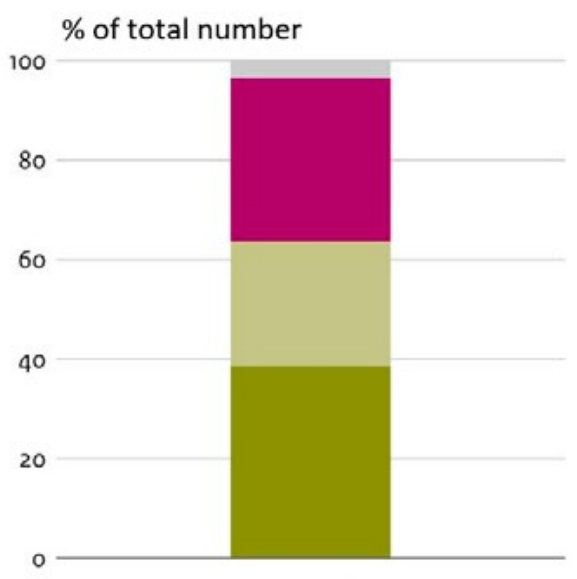

BD species

Bron: Ministerie van LNV; bewerking PBL

Figure 9. Conservation status of habitats and species and population trend of bird species

\section{Trends in Habitats types and Habitat Directive species with an unfavourable conservation status}

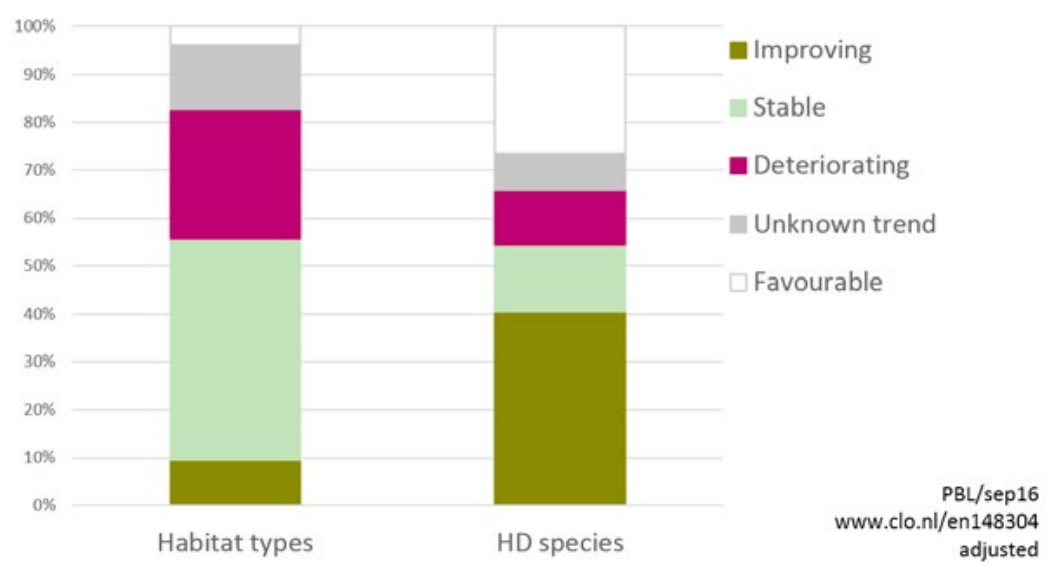

Figure 10. Trends in the conservation status of habitats and species 


\section{Winter mortality of bees}

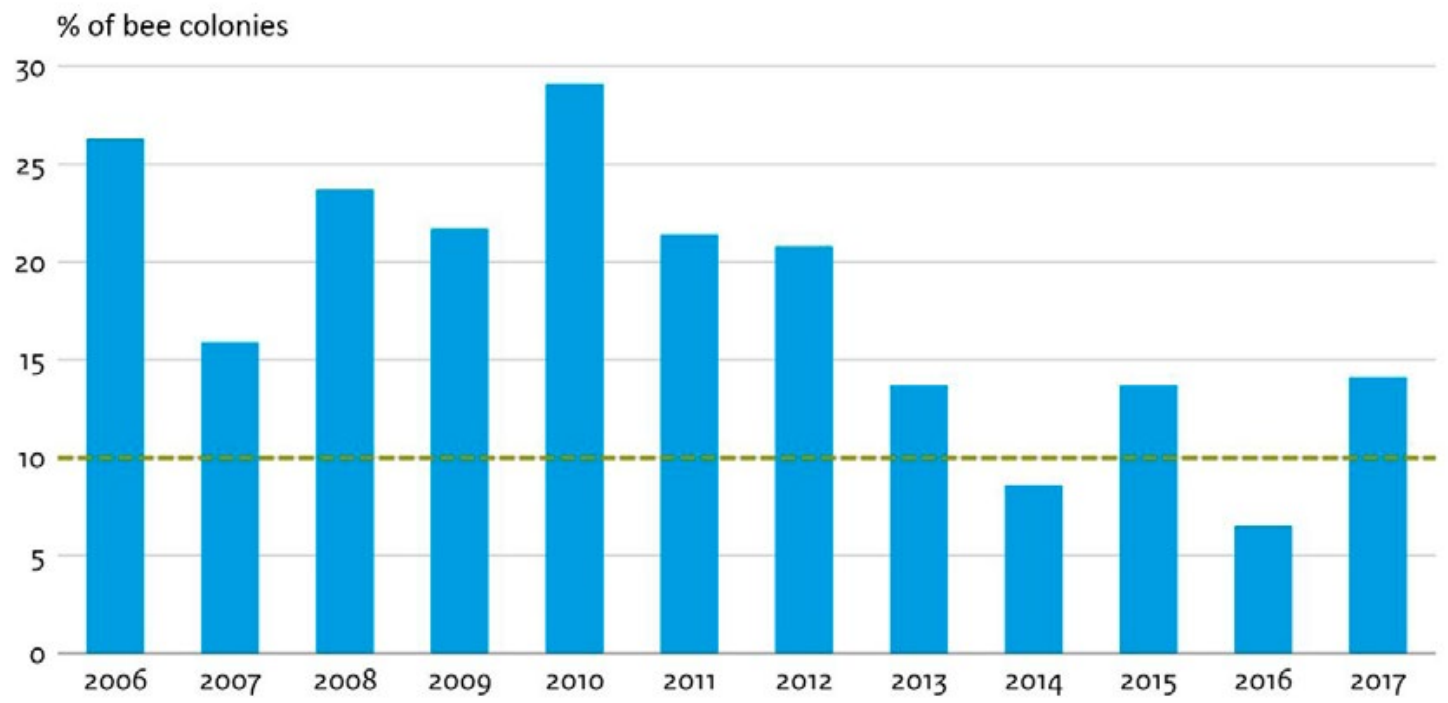

Average mortality

- - Normal mortality (Hendrikx et al. 2009)

Bron: Van der Zee 2015; NBV 2017

PBL/jun17

www.clo.nl/nlo57204

Figure 11. Average winter mortality of bee colonies

evaluation of most services is still at an early stage, as is the process towards safeguarding and restoring them ${ }^{98}$. There is currently a strong research focus on clarifying the current situation. One of the actions of the Natural Capital Agenda is the development of the digital Atlas of Natural Capital in the Netherlands. This will form the basis for formulating policy strategies to map ecosystem services, applying the TEEB (the economics of ecosystems and biodiversity) approach, and restoring and safeguarding essential ecosystem services. Here we present a few services which have received special attention.

\section{Pollination and bees}

Pollination is an essential ecosystem service and as such the impacts of pesticides on nature, especially on bees, is receiving special attention. Honey bees, wild bees and several other species of insects are important for food security and for pollinating agricultural crops and fruit

98 https://themasites.pbl.nl/natuurlijk-kapitaal-nederland/wp-content/ uploads/2014/PBL_2016_Natuurlijk-kapitaal_1455.pdf trees. In the Netherlands, the winter mortality of bee colonies is often higher than normal (Figure 11) and more than half of the wild bees are on the national Red List (Figure 12). ${ }^{99}$ From 2003 to 2018 the number of species on the Red List increased and the species on the list became more threatened. The Natural Capital Agenda 2013 outlines some concrete actions to redress this situation. The Dutch government gives incentives to farmers to create arable field margins with wild flowers to facilitate functional agro-biodiversity, stimulates the use of non-chemical methods and requires farmers to use emission reducing techniques. The government and social partners have drawn up and signed a national bee strategy $^{100}$ (see also section III-5).

\section{Restoring of ecosystem services along rivers}

A successful programme for restoring ecosystem services related to water, climate adaptation and human safety is

\footnotetext{
99 http://www.bestuivers.nl/rodelijst

100 https://www.rijksoverheid.nl/onderwerpen/natuur-en-biodiversiteit/ bijenstrategie
} 


\section{Red List Bees}

Number of bee species

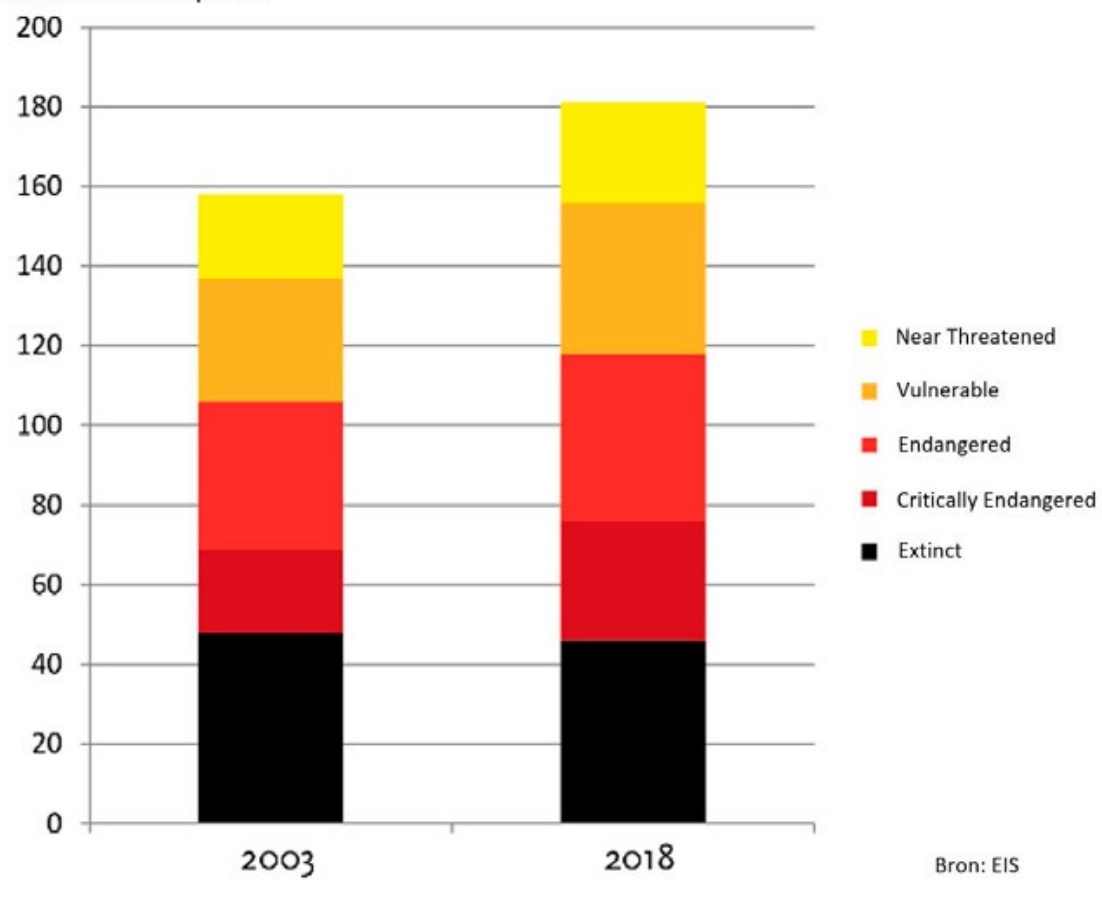

Figure 12. Red List of bee species

the Room for the River programme. The goal of this programme was to give the main rivers more room for dynamic processes and to better manage higher discharge levels in the face of the expected effects of climate change. Adapting to changing sea levels and river discharge patterns is essential in order to provide the necessary protection against flooding and ensure acceptable levels of public safety. At more than 30 locations, measures have been taken to provide the river with larger areas of floodplain and increase protection against flooding. The measures have also been designed in such a way that they improve the ecological, landscape and recreational quality of the immediate surroundings. Monitoring reveals a strong increase in natural values during the 20 years of habitat creation and restoration along the main rivers ${ }^{101}$. On 22 March 2018 the minister of infrastructure and water management presented the Room for the River final evaluation to the House of Representatives ${ }^{102}$.

101 http://rijninbeeld.nl/wp-content/uploads/Rijn-en-Beeld-brochure-Irnc.pdf 102 http://publicaties.minienm.nl/documenten/

ruimte-voor-de-rivier-oogst-ruimtelijke-kwaliteit

\section{IV-3 By 2020, the conservation of species and habitats depending on or affected by agriculture and forestry, and the provision of their ecosystem services, show measurable improvements}

Compared with forestry the agriculture sector has made less progress towards sustainability, despite the positive and substantial efforts made under the common agricultural policy, such as the agri-environmental schemes.

\section{Agriculture}

The populations of species that depend on agriculture are still decreasing. Populations of breeding birds, insects and butterflies (Figure 13) in particular are decreasing, while most species of mammals (such as badger and hare) persist or are on the increase. ${ }^{103}$ The decline in population numbers is mainly due to the intensive use of agricultural land. Changes in crop choice, pesticide use, mechanisation and the increase in the scale of agricultural operations have led to changes in food availability, nesting and chick

103 https://www.clo.nl/indicatoren/nl1580-trend-fauna-agrarisch 


\section{Butterflies in grassland}
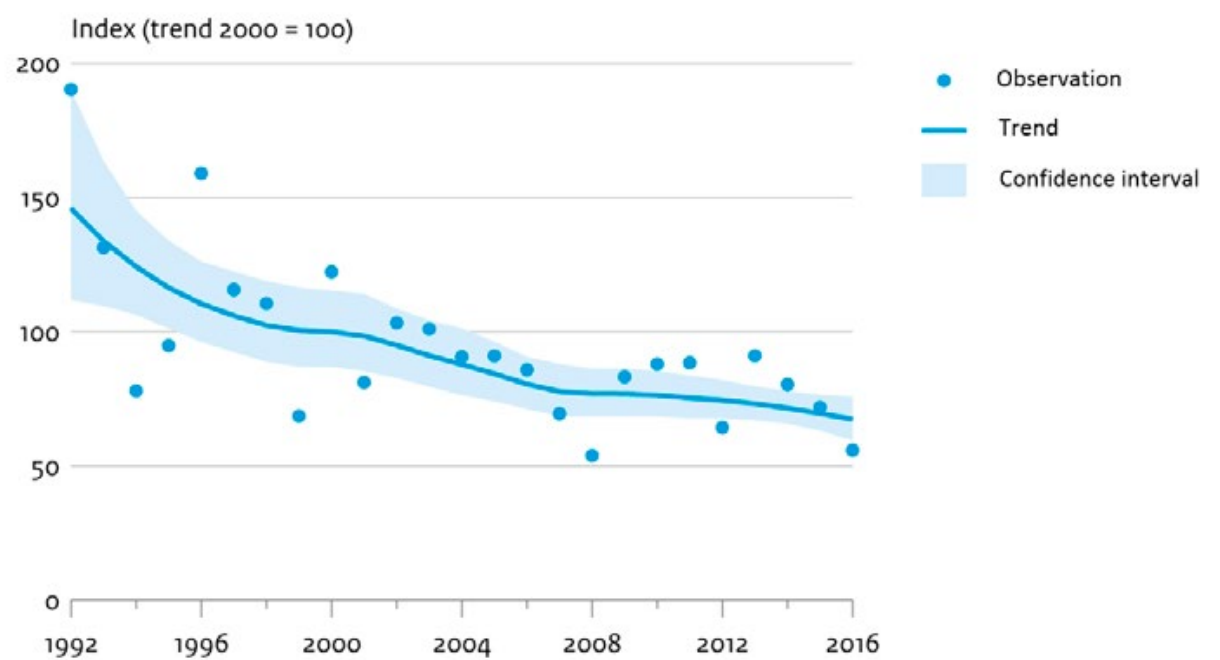

Bron: NEM (Vlinderstichting, CBS)

Figure 13. Trend in butterfly populations in agricultural grassland

\section{Nutrient surpluses in agriculture}

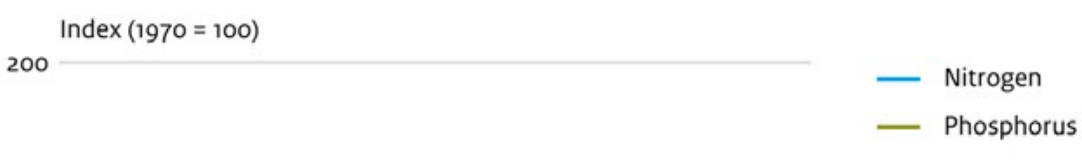

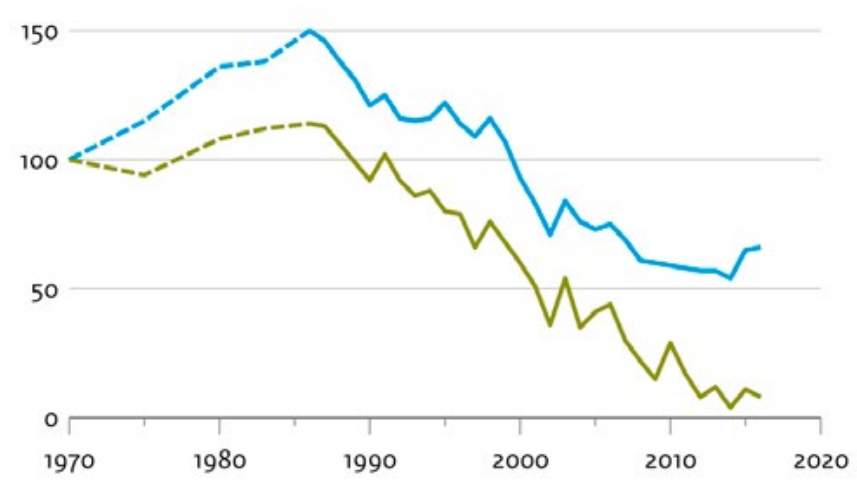

Source: CBS

Figure 14. Nutrient surpluses in agriculture 
survival and to the disappearance of small landscape elements such as hedgerows and small unproductive areas with wild flowers. Since the 1980s various agri-environment schemes have been implemented in an attempt to reverse the trend, but have not succeeded. The populations of farmland birds are still decreasing and considerable efforts are being made to find a new system to improve farmland biodiversity (Figure 7, section III-3). Time will show if this new system is more effective. The number of species and habitats indirectly affected by agriculture is large. Most habitats and many species are sensitive to nitrogen overload, pesticides, lowered water tables, etc. Across large areas of different ecosystems the deposition levels still exceed the critical loads for sustaining good ecological quality ${ }^{104}$. The sector is moving towards greater sustainability, but progress is slow. Nitrogen, phosphate and other nutrient surpluses (Figure 14) can lead to pollution of soil, water and air. Policy measures and other efforts being made by the sector did bring down these surpluses in Dutch soils, but they rose again in 2015, possibly due to an increase in livestock numbers after the abolition of the EU milk quota.

Organic farming is considered a promising strategy for making agricultural and horticultural production more sustainable. In 2017, just $3.1 \%$ of all Dutch farmland was under organic farming. In comparison with other European countries, the organic farming sector in our country is small ${ }^{105}$, but it is growing. Between 2011 and 2018, the area under organic farming increased by $19 \%$ from 47,000 to 58,000 ha $^{106}$. This growth mainly took place in the area of grassland (23\%) and open field horticulture (61\%). In 2018 the organic farming area was 3\% larger than in the previous year (see also Aichi Targets 4). In response to this lack of progress, a social movement has arisen to work towards the closing of nutrient cycles and for nature-inclusive farming across the entire agricultural sector, not only in the $10 \%$ of agricultural areas that are under agri-environmental management. This is supported and underlined by a broad social alliance of agricultural and nature conservation organisations and various parties in the agricultural trade chain, who have published a Delta Plan for Biodiversity Recovery ${ }^{107}$.

\footnotetext{
104 https://www.clo.nl/en/indicators/ en2045-overfertilization-in-the-national-ecological-network 105 https://ec.europa.eu/eurostat/statistics-explained/index. php?title=File:Organic_farming_area_EU_and_EFTA.rev.jpg 106 https://www.clo.nl/indicatoren/nl0011-biologische-landbouw 107 https://www.samenvoorbiodiversiteit.nl/wp-content/uploads/2018/12/ Deltaplan-Biodiversiteitsherstel.pdf
}

\section{Forestry}

All forests in the Netherlands are legally protected and many of them are sustainably managed. About $46 \%$ of the forest area is FSC certified. ${ }^{108}$ The populations of typical breeding birds of forests are on average increasing (Figure 15). Forest butterflies show a more mixed picture. ${ }^{109}$ Dutch forests have undergone substantial changes in recent decades. The age structure of many forests is rising and their composition and management is more varied; dead wood is often left in place rather than being removed (Figure 16). Many monoculture stands of pine are being transformed into more natural mixed forest and deciduous forest. New forest areas are advantageous for some birds, while other species do well in the older forests. Some species of older forests are decreasing, including wood warbler and black woodpecker. Some bird species of coniferous forest (crested tit, coal tit) are also decreasing, possibly because coniferous forests are being transformed into deciduous forest. Birds of prey, such as buzzard, hawk and sparrowhawk are on the increase in forests on clay and peat soils, but are declining in forests on sandy soils because they find little good quality food there ${ }^{110}$. On average, populations of typical breeding birds of forests are increasing.

\section{IV-4 By 2015, fishing is sustainable. By 2020, fish stocks are healthy and European seas healthier. Fishing has no significant adverse impacts on species and ecosystems}

The EU is responsible for policies on managing marine living resources in Europe and elsewhere where European fisheries operate. The new common fisheries policy (CFP), which entered into force in 2014, applies to fishing by EU vessels in international waters and in territorial waters of third countries, unless agreements with the third country state otherwise. The current policy stipulates that between 2015 and 2020 catch limits should be set that are sustainable and maintain fish stocks in the long term. Important fish stocks such as herring, sole and plaice (Figure 18) are above safe biological limits and also above sustainable

\footnotetext{
$108 \mathrm{http}: / /$ www.bosenhoutcijfers.nl/nederlands-bos/boscertificering/ 109 https://www.clo.nl/indicatoren/nl1162-fauna-van-het-bos

110 Boele A., van Bruggen J., Hustings F., Koffijberg K., Vergeer J.W. en van der Meij T. (2016). Broedvogels in Nederland in 2014. Sovon-rapport 2016/04. Sovon Vogelonderzoek Nederland, Nijmegen.
} 


\section{Breeding birds of forests}

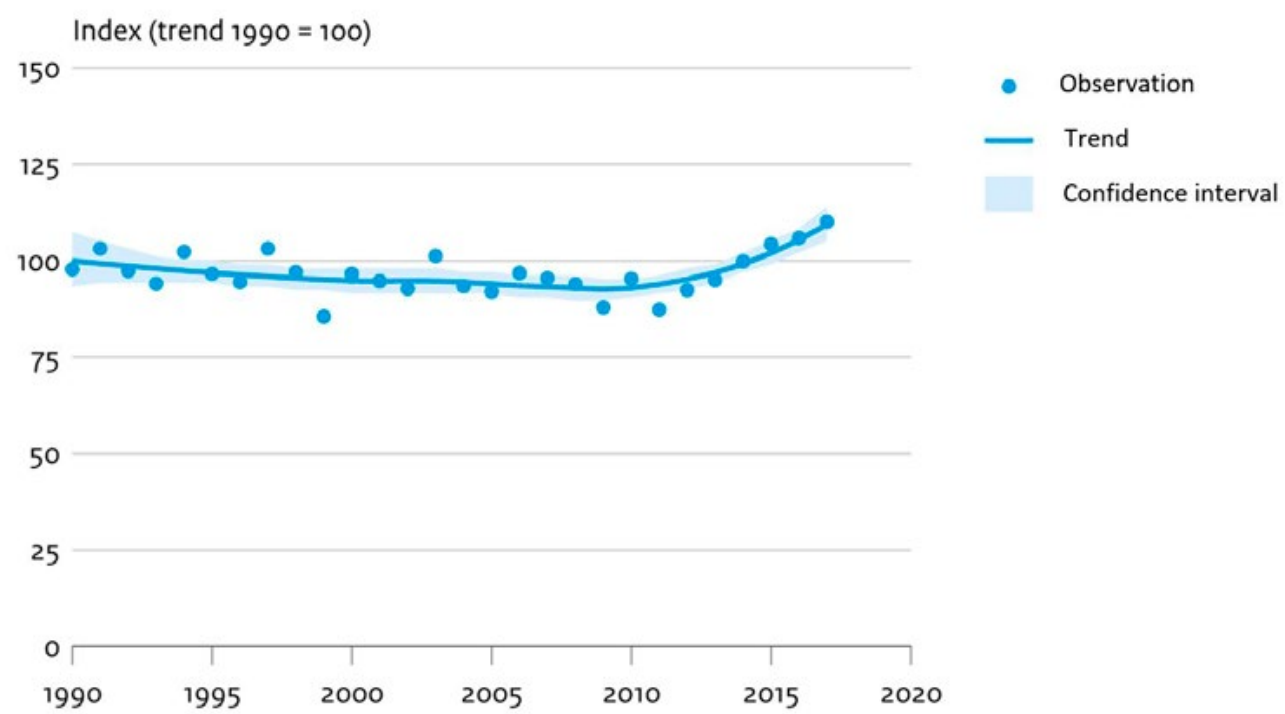

Bron: NEM (Sovon, CBS)

Figure 15. Trend in total population of breeding birds of forests

\section{Standing and lying dead tree trunks}

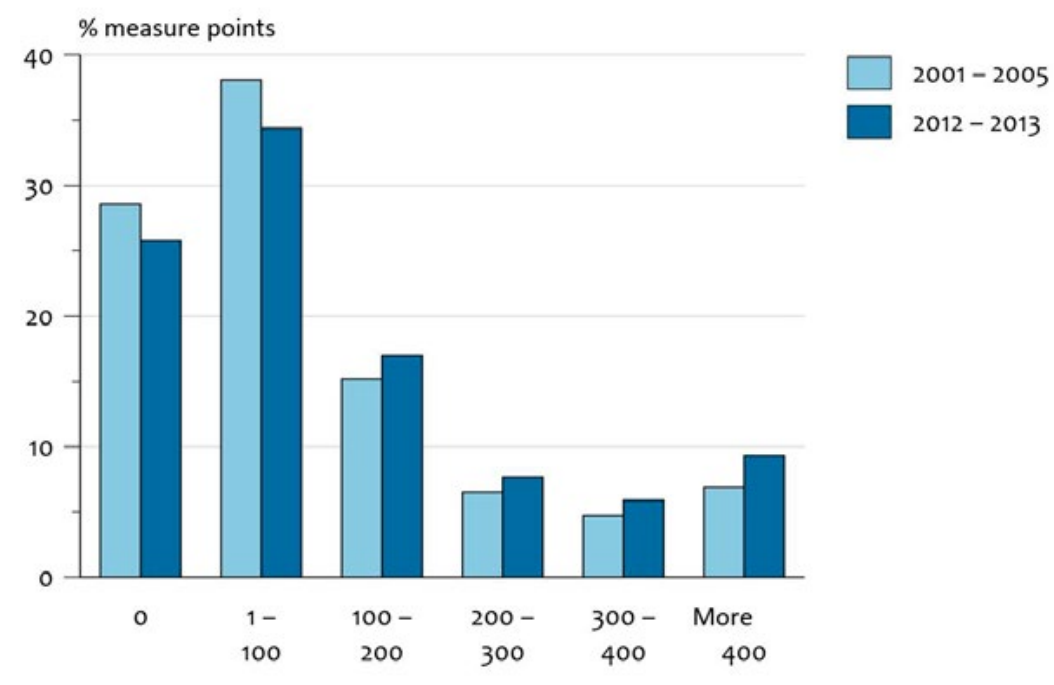

Number of tree trunks per hectare of forest

Bron: Schelhaas et al., 2014 (database 6de Bosinventarisatie).

Figure 16. Standing and lying dead wood in forests 


\section{Fish stocks in the North Sea: Cod}

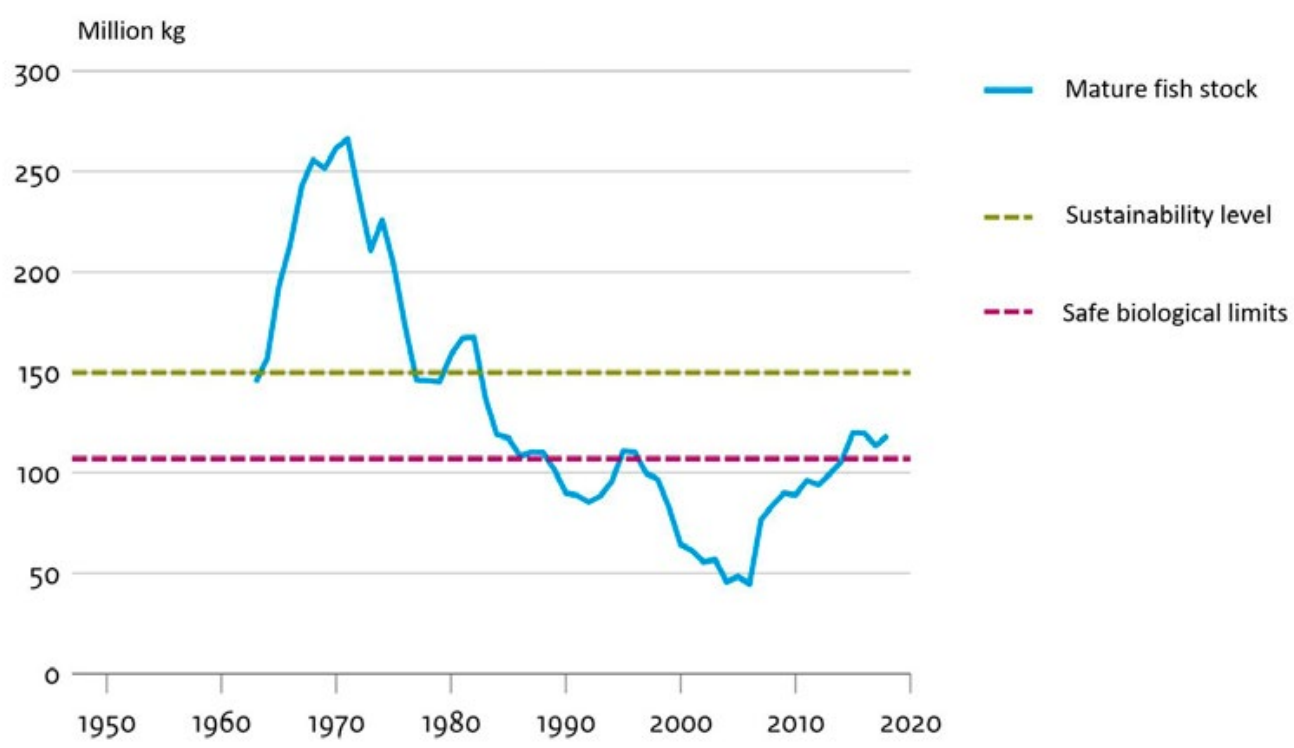

Bron: ICES 2018

Figure 17. Trend in stock size of cod in the North Sea

\section{Fish stocks in the North Sea: Plaice}

Million $\mathrm{kg}$
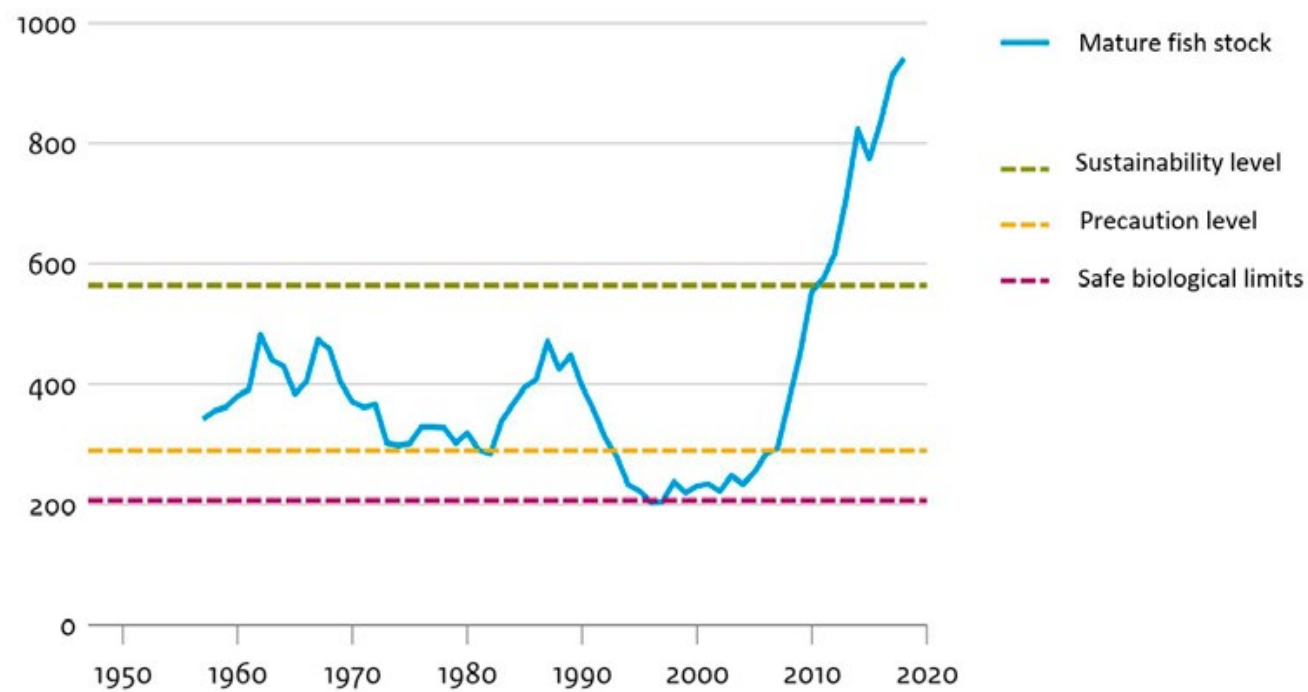

Bron: ICES 2018

Figure 18. Trend in stock size of plaice in the North Sea 


\section{Egg capsules of sharks and rays}

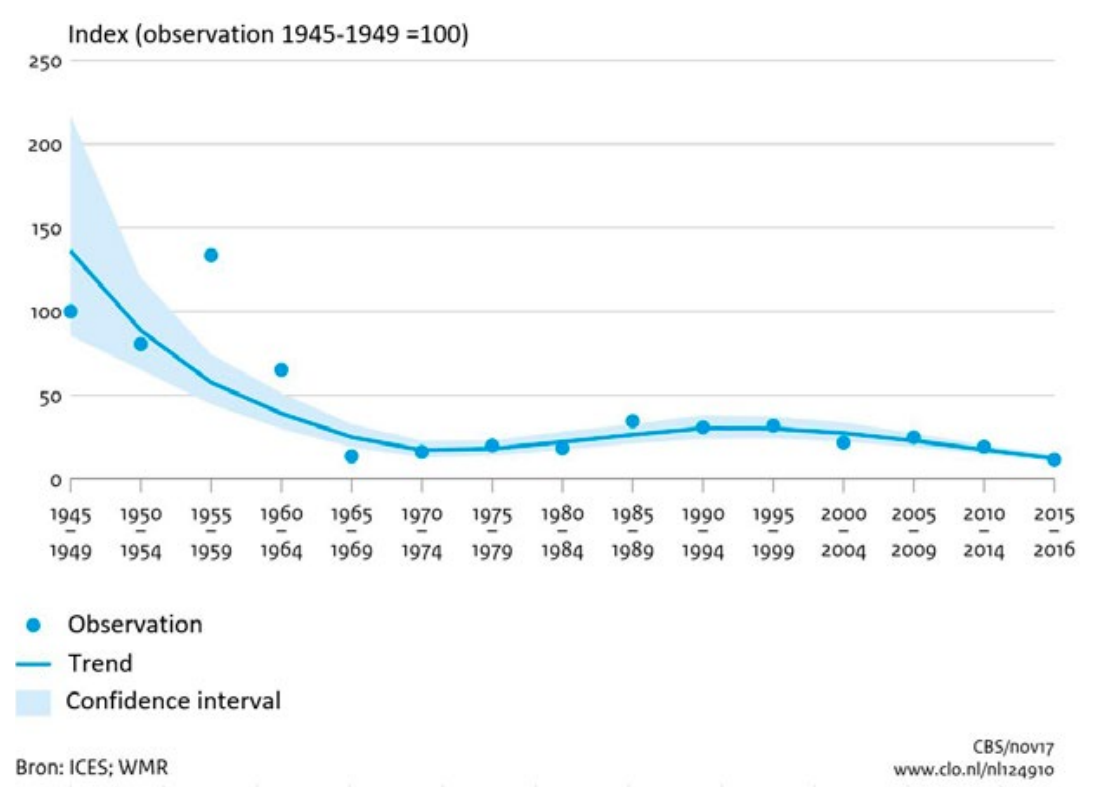

Figure 19. Trend in numbers of egg capsules of sharks and rays in the North sea

levels. ${ }^{111}$ The cod population is not yet above the sustainable level (Figure 17).

Not all the effects of unsustainable fisheries have been restored. Vulnerable long-lived shark and ray species are still critically endangered or threatened (Figure 19) and many populations of benthos species - animals living near, on or in the seabed - have decreased since 1990 and no signs of recovery have yet been recorded (Figure 20). In demersal trawl fisheries (for seabed species) rays and sharks are also caught as a by-catch. The Netherlands has adopted a shark and ray recovery action plan 2015-2021 under the Marine Strategy Framework Directive (MSFD) ${ }^{112}$.

The CFP contains an obligation to land all catches of regulated fish species; discards are prohibited. In addition, the Dutch government stimulates technical and other innovations for more sustainable fisheries with fewer discards. Important examples of research and innovation are the transition from mussel seed fishing to mussel seed capture installations and the transition from traditional beam trawl fishing to electric pulse fishing. While ICES concludes that pulse trawling has fewer environmental and

111 https://www.clo.nl/indicatoren/nl0073-visbestanden-in-de-noordzee 112 https://www.rijksoverheid.nl/documenten/kamerstukken/2019/05/01/ kamerbrief-voortgang-krm-haaienactieplan-noordzee-en-internationalehaaienstrategie-inclusief-caribisch-nederland ecological effects than beam trawls ${ }^{113}$, electric pulse fishing is being reduced and will be banned in the EU from July 2021.

Several other international agreements regarding the North Sea are implemented: VIBEG, MFSD, OSPAR. Under the VIBEG agreement ${ }^{114}$, parts of the marine Natura 2000 areas (North Sea Coastal Zone and the Vlakte van Raan) are closed to certain categories of fishing that have an impact on bottom life or can disturb sea mammals and birds. Measures under the MSFD are currently being implemented to conserve marine biodiversity with the aim of achieving good environmental status by 2020 . The maintenance of biodiversity (birds, fish, sea mammals and pelagic and benthic habitats) is one of 11 qualitative descriptors of what the environment will be like when good environmental status has been achieved. The EU Member States work together on regional implementation of the MSFD. The OSPAR Convention for the protection of the marine environment of the North-East Atlantic has been an effective regional platform for international

113 https://www.rijksoverheid.nl/documenten/kamerstukken/2018/05/30/ bijlage-1---advice-explainer-ecological-and-environmental-effects-of-pulsetrawling

114 https://www.msp-platform.eu/practices/

vibeg-agreement-and-steering-group-stimulating-sustainable-fisheries-dutchnorth-sea 


\section{Benthos (animals living near, on, or in the seabed) in the North Sea}

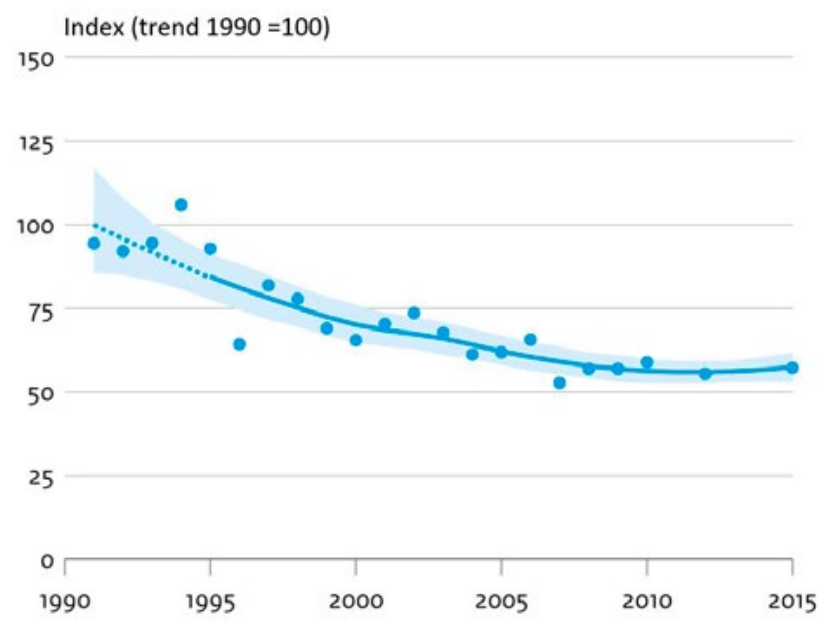

- Observation

..... Trend (16 sample stations)

- Trend (84 sample stations)

Confidence interval

Bron: RWS

Figure 20. Trend in benthos abundance in the North sea

cooperation on the North Sea, for example through the development of common indicators and the Intermediate Assessment 2017. According to the Dutch Marine Strategy (Part 1, 2018-2024) ${ }^{115}$, good environmental status of biodiversity based on OSPAR indicators has not been reached, but the environmental status for biodiversity is improving.

The Marine Strategy defines the target for the good environmental status for commercial fish stocks as follows: "By 2020, all commercially exploited fish species will remain within safe biological limits and show a structure in terms of age and size that is characteristic of a healthy stock'. While reasonable progress has been made, the target has not yet been reached"116. According to the status assessment for the International North Sea published in the Dutch Marine Strategy, which was based on file assessments from $2016^{117}, 7$ (or $26 \%$ ) of the

115 Ministerie van Infrastructuur en Waterstaat \& Ministerie van Landbouw, Natuur en Voedselkwaliteit, 2018. Mariene Strategie (deel 1) Actualisatie van huidige milieutoestand, goede milieutoestand, milieudoelen en indicatoren. 2018-2024.

116 Gepubliceerd in: Mariene Strategie voor het Nederlandse deel van de Noordzee 2012-2020 (deel 3). KRM-programma van maatregelen. Bijlage 5 bij het Nationaal Waterplan 2016-2021.

117 Ministerie van Infrastructuur en Waterstaat \& Ministerie van Landbouw, Natuur en Voedselkwaliteit, 2018. Mariene Strategie (deel 1) Actualisatie van huidige milieutoestand, goede milieutoestand, milieudoelen en indicatoren. 2018-2024.
27 commercial fish, shellfish and crustaceans meet the good environmental status threshold for the criteria 'fishing mortality rate' and 'spawning stock biomass'.

\section{IV-5 By 2020, invasive alien species are identified, priority species controlled or eradicated, and pathways are managed to prevent new invasive species from disrupting European biodiversity}

The invasive alien species and their pathways have been identified and measure are being taken, but the number of alien species in the Netherlands and Europe is still increasing (Figure 21). In September 2013, recognising the increasingly serious problem of invasive alien species in Europe, the European Commission published a dedicated legislative instrument on invasive alien species, the IAS Regulation, to tackle this problem in a coordinated and concerted way across all Member States ${ }^{118}$. At the core of the IAS Regulation is the List of Invasive Alien Species of Union concern, referred to as the Union list. ${ }^{119}$ The IAS Regulation imposes restrictions on the keeping, importing,

118 https://eur-lex.europa.eu/legal-content/EN/TXT/PDF/?uri=CELEX:32014R114 3\&from $=E N$

119 Union list: http://ec.europa.eu/environment/nature/invasivealien/list/ index_en.htm 


\section{Number of alien species}

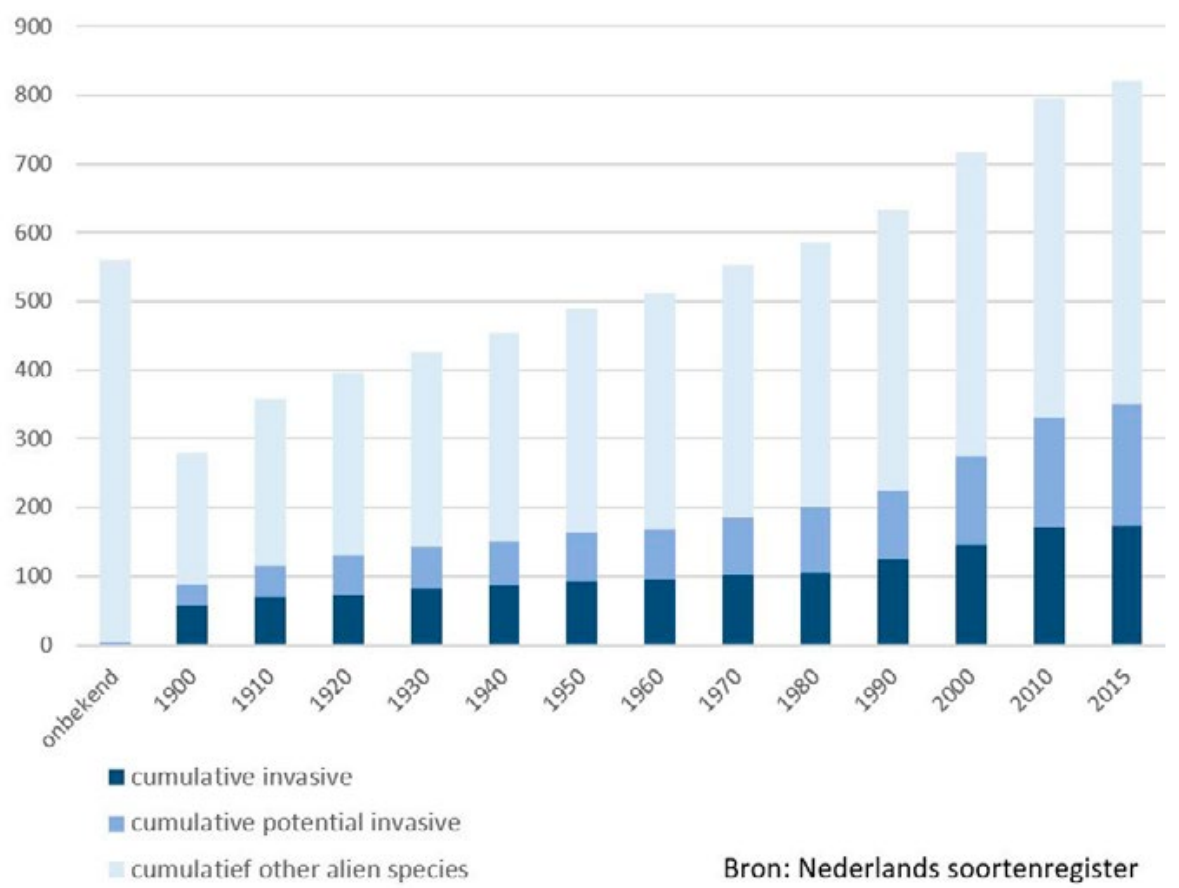

Figure 21. Numbers of alien, potential invasive and invasive alien species in the Netherlands since 1900

selling, breeding and growing of the listed species. Member States are required to take measures for their early detection and rapid eradication, and to manage populations that are already widely spread in their territory. The Union list is updated at regular intervals.

The Dutch Ministry of Agriculture, Nature and Food Quality asked the Netherlands Food and Consumer Product Safety Authority (NVWA) to advise on the Dutch approach per Union listed species. This advice has been laid down in a strategy document on Union list species ${ }^{120}$. The NVWA also advised the ministry of species that might be added to the Union list. The risk of additional alien species becoming invasive has been assessed and reported on by the Invasive Alien Species Team (Team Invasieve Exoten) and species experts. The list and the risk assessments are available on the website of the NVWA. ${ }^{121}$

120 https://www.nvwa.nl/documenten/dier/dieren-in-de-natuur/exoten/ publicaties/onderbouwing-strategie-unielijstsoorten

121 https://www.nvwa.nl/onderwerpen/invasieve-exoten/ risicobeoordelingen--reactieperiode-invasieve-exoten.
Many actions have been taken to identify pathways (Figure 22) and eradicate or control potentially invasive alien species. Nevertheless, the number of alien species is still growing, especially in aquatic environments, especially due to freshwater infrastructure connections between the Black Sea and the North Sea, which poses a major management challenge. Introduction pathways such as trade and use are regulated by law (see section II-2). The Nature Conservation Act prohibits the release of animal and plant species in the wild as well as the possession of and trade in certain alien species. The law makes it possible to act when invasive alien species are introduced.

Aquatic invasive alien species are much more difficult to control and eradicate than terrestrial species, which puts the emphasis on prevention. To prevent the introduction of marine alien species via the ballast water of ships, in 2010 the Netherlands signed the International Convention for the Control and Management of Ships' Ballast Water and Sediments (BWM) under the auspices of the International Maritime Organization (IMO). The essence of this agreement is that ships must have an approved ballast water treatment plant which removes organisms. 
The BWM Convention has been signed by 66 Parties representing $75 \%$ of world trade tonnage and entered into force on 8 September $2017^{122}$.

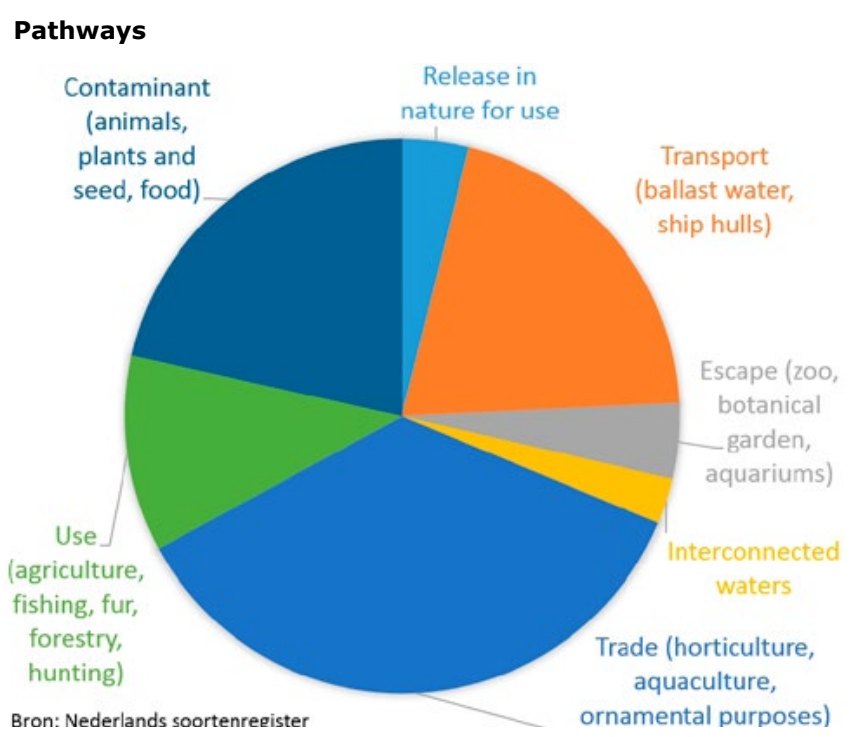

Figure 22. Pathways of alien species in the Netherlands

\section{IV-6 By 2020, the EU has stepped up its contribution to avert global biodiversity loss}

Major steps have been taken to keep the impacts from the use of natural resources within safe ecological limits, although there are still concerns about the reform of the agricultural sector and the ecological footprint of the Netherlands, especially abroad. The road to sustainability is a long one, but reasonable progress has been made. The international target of doubling biodiversity-related funding flows to developing countries by 2015 and maintaining them until 2020 has not been reached. The Netherlands is actually moving away from this target (see Aichi Targets 20).

Total consumer spending on sustainable food examined in a sample of stores and other outlets (supermarkets, specialist sustainable food shops and hospitality and food service outlets) amounted to EUR 4.5 billion in 2017: a $19 \%$ increase on $2016^{123}$. The proportion of sustainable food as a percentage of total expenditure on food rose from $10 \%$ in 2016 to $11 \%$ in 2017 . A large proportion of the raw materials consumed in the Netherlands are produced abroad.

The Netherlands contributes to averting global biodiversity loss by stimulating sustainable trade and production and supporting biodiversity protection elsewhere. The Natural Capital Agenda focuses - both nationally and internationally - on the conservation and sustainable use of biodiversity. The focus of ecosystem services protection lies on the implementation and management of Natural Capital targets and promoting sustainable production and consumption. As the Netherlands is a relatively small and density populated country with a large international footprint, most of the effects of promoting sustainable supply chains are outside the Netherlands. Dutch foreign development policy focuses on fair and sustainable growth and prosperity from which everyone benefits. The core of the policy is stated in the document 'What the World Deserves: A new agenda for aid, trade and investment ${ }^{\prime 24}$. The Dutch government has played a facilitating and stimulating role in the transition process to sustainable consumption and production through its financial support to voluntary initiatives, its procurement policy and the conclusion of letters of intent with market parties. The parties involved have often taken important steps in the sustainability process on a voluntary basis, but are now faced with obstacles of a financial and administrative nature ${ }^{125}$. That is why market-wide agreements are needed at a European level to stimulate sustainable trade and to create a level playing field between Member States. The Netherlands has an active role in this. For example, in 2016 a conference on sustainable trade by several EU Member States adopted an initiative for the use of sustainable palm oil (Amsterdam Palm Oil Declaration).

The Dutch government also supports the Fair Green Global Alliance ${ }^{126}$ of six civil society organisations (Both ENDS, SOMO, Milieudefensie and others) which works to alleviate poverty, advocate at various levels for more sustainable consumption and production, and strengthen civil society

123 https://www.agrimatie.nl/ThemaResultaat. aspx?subpubID $=2232$ \&themaID $=2810$ \&indicatorID $=2659$ 124 https://www.government.nl/documents/letters/2013/04/05/ global-dividends-a-new-agenda-for-aid-trade-and-investment 125 https://www.clo.nl/en/node/26339 126 https://fairgreenandglobal.org/ 
Market shares of resources with a sustainability label in Dutch consumption and industrial use

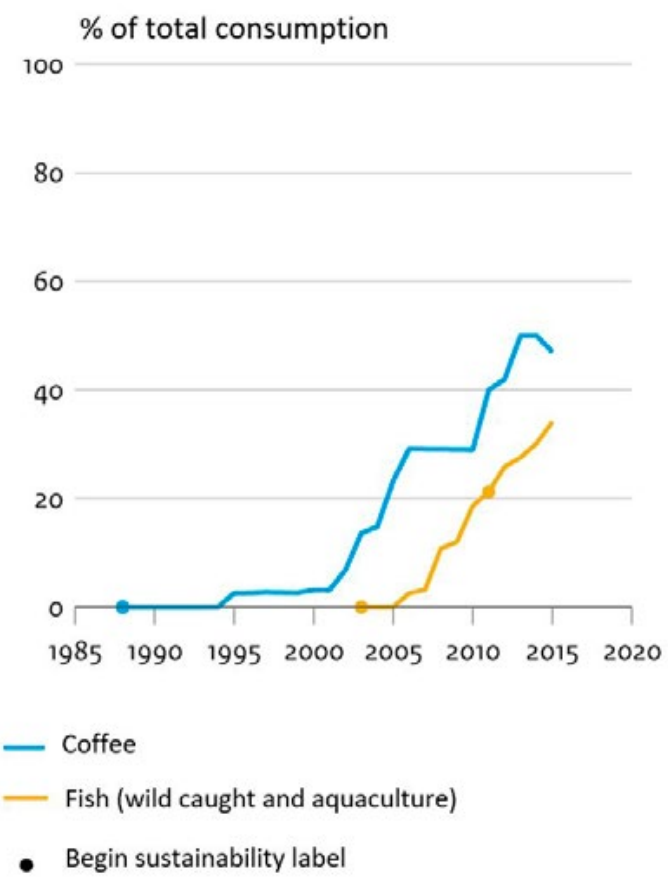

Bron: PBL

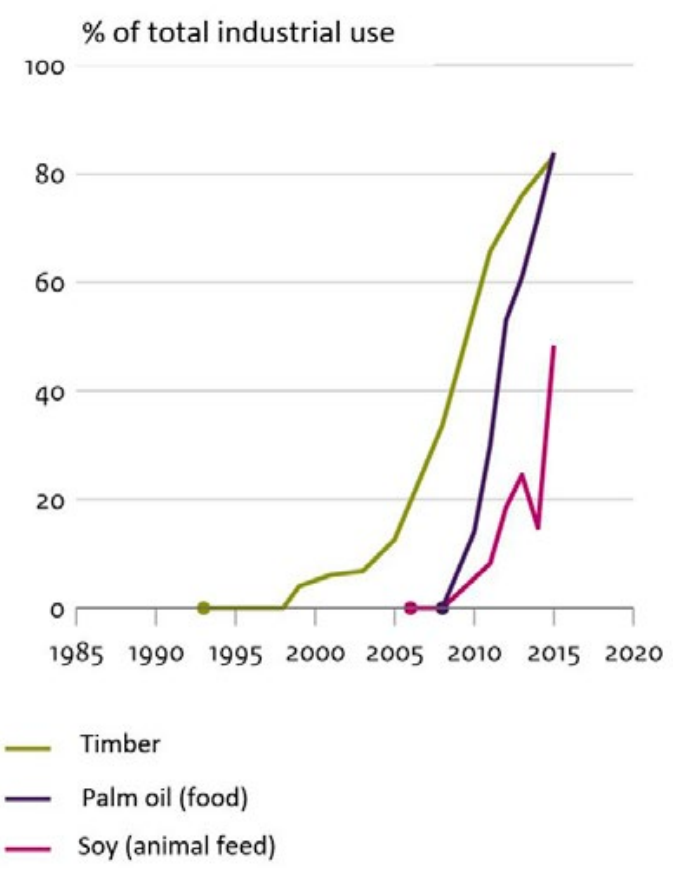

PBL/sep17 www.clo.nl/nlo58002

Figure 23. Market shares of raw materials with a sustainability label in Dutch consumption and industrial use

organisations in tropical and subtropical developing countries.

\section{Sustainability labels}

Governments, businesses and stakeholders at all levels are taking steps to establish sustainable production methods and consumption patterns. The market shares of a number of biotic raw materials imported into the Netherlands with a sustainability label have increased substantially in recent decades (Figure 23). Obtaining a sustainability label is a voluntary decision. Labels such as Fair Trade for coffee, RTRS for responsibly grown soy, MSC for sustainably caught fish and FSC for sustainably produced timber employ internationally accepted standards for sustainable production. All of these standards, to different degrees, incorporate principles and criteria on biodiversity protection and/or zero deforestation.

There is considerable debate about the effectiveness of certification $^{127}$. The production methods prescribed in standards have potentially positive effects, but it is not clear is to what degree the certification process induces improvements in methods used or simply certifies practices that were already compliant. In response to the shortcomings of the certification approach, Dutch policies are increasingly putting their weight behind jurisdictional and landscape scale sustainable production approaches (Natural Capital Accounting, IDH).
127 Potts, J., Voora, V., Lynch, M. \& Mammadova, A. (2016) Voluntary Sustainability Standards and Biodiversity: Understanding the potential of agricultural standards for biodiversity protection IISD The International Institute for Sustainable Development; https://www.pbl.nl/sites/default/files/ cms/publicaties/PBL_2015_Duurzame\%20handelsketens\%20onder\%20 de\%20loep_1147.pdf 



\section{Aichi Biodiversity Targets}

\section{Strategic Goal A:}

\section{Address the underlying causes of biodiversity loss}

1 Awareness of biodiversity increased

2 Biodiversity values integrated

3 Incentives reformed

4 Sustainable production and consumption

\section{Strategic Goal B:}

\section{Reduce the pressures on biodiversity and promote} sustainable use

5 Habitat loss halved or reduced

6 Sustainable management of aquatic living resources

7 Sustainable agriculture, aquaculture and forestry

8 Pollution reduced

9 Invasive alien species prevented and controlled

10 Ecosystems vulnerable to climate change
Strategic Goal D:

\section{Enhance the benefits to all}

14 Ecosystem services

15 Ecosystem restoration and resilience

16 Access to and sharing benefits from genetic resources

\section{Strategic Goal E:}

\section{Enhance implementation}

17 Biodiversity strategies and action plans

18 Traditional knowledge

19 Sharing information and knowledge

20 Mobilising resources from all sources

\section{Strategic Goal C:}

\section{Improve the status of biodiversity}

11 Protected areas

12 Reducing risk of extinction

13 Safeguarding genetic diversity 


\title{
Strategic Goal A
}

\author{
Address the underlying causes of biodiversity loss by mainstreaming \\ biodiversity across government and society
}

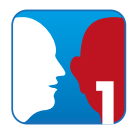

Target 1

Awareness of biodiversity increased

\section{By 2020, at the latest, people are aware of the values of biodiversity and the steps they can take to conserve and use it sustainably}

\section{Why is this target important?}

Addressing the direct and underlying drivers of biodiversity loss will require behavioural change by individuals, organisations and governments. Understanding, awareness and appreciation of the diverse values of biodiversity help to underpin the willingness of individuals to make such changes. Public awareness also underpins the political will for governments to act. To meet this target, people must not just be aware of the values of biodiversity in an abstract way, but know the concrete contributions biodiversity makes to their lives, as well as the actions that can be taken to conserve and sustainably use biodiversity ${ }^{128}$.

\section{Summary of progress towards the target}

Based on the current status and positive trend in biodiversity awareness in the Netherlands and the ongoing initiatives, it can be concluded that awareness is relatively high and still increasing. Aichi Targets 1 maybe considered to have been achieved. Progress towards Aichi Targets 1 in the Caribbean Netherlands, Aruba, Curaçao and St Maarten is assessed as being 'on track to achieve target'.

\section{Dutch contribution to the achievement of Aichi Target 1}

The Netherlands has always pursued active programmes at all levels of government to support awareness raising and communication on biodiversity and nature. The

128 Global Biodiversity Outlook A mid-term assessment of progress towards the implementation of the Strategic Plan for Biodiversity 2011-2020 government's vision on nature The Natural Way Forward specifically mentions:

- support for the consultative panel 'Green Table Human Capital Agenda Natural Living Environment', established by representatives from the green education sector and partners from the private sector to train future employees and educational institutions for a green future;

- support for green education within and outside schools, for instance by stimulating green school playgrounds and city farms and the educational programme Duurzaam Door.

The government increasingly delegates the responsibility for awareness raising to NGOs, private parties and businesses and gives organisations such as the Institute for Nature Education (IVN) and Staatsbosbeheer financial support to organise awareness raising.

A European survey shows that most European Union citizens have heard of the term 'biodiversity', but less than one third knows what it means. Dutch citizens have heard of biodiversity more often than the average in the European Union (Figure 24), but they are a little less positive about the importance of biodiversity than the average European respondent (Figure 25).

Most Dutch citizens ( $81 \%$ ) have an affinity with nature to some degree and $94 \%$ of respondents believe nature conservation is very important. ${ }^{129}$ They are aware of biodiversity in their surrounding area, visit nature reserves and carry out low-threshold activities to maintain it (like feeding birds during winter). About $16 \%$ are not only interested in nature but also take part in conservation work to some extent, while $12 \%$ can be considered to be highly involved and active as nature conservationists and decision makers. The sizes of these groups remained virtually unchanged between 2013 and 2017.

129 Boer, T.A. de, and F.L. Langers, 2017. Maatschappelijk draagvlak voor natuurbeleid en betrokkenheid bij natuur in 2017. Technical report 102, Wettelijke Onderzoekstaken Natuur \& Milieu, Wageningen. 


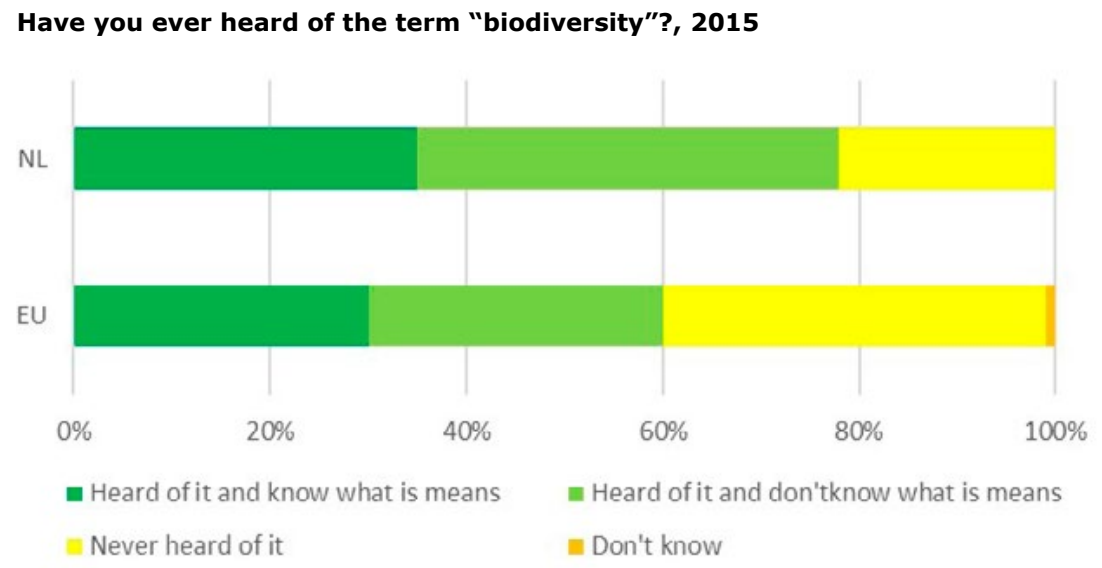

Figure 24. Percentage of respondents that had heard of the term 'biodiversity'.129

\section{Respondent agreement biodiversity importance}

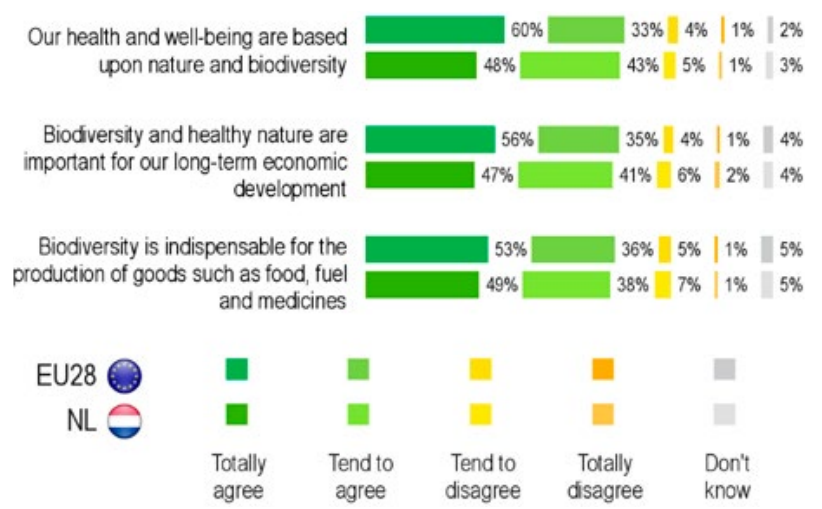

Figure 25. Percentage of respondents who think biodiversity is important. ${ }^{131}$

Dutch NGOs are very successful in organising activities to increase public awareness and involve citizens in their activities. For example, the Natuur- en Milieufederaties (nature and environment federations) have more than 1,000 affiliated local volunteer organisations. Thousands of volunteers are active in nature and landscape management. The number of volunteers can vary considerably from year to year and between organisations. The number of volunteers participating in the Natuurwerkdag (Nature

130 European questionnaire 'Attitudes towards biodiversity' http://ec.europa.eu/ COMMFrontOffice/publicopinion/index.cfm/Survey/getSurveyDetail/ instruments/SPECIAL/surveyKy/2091

131 European questionnaire 'Attitudes towards biodiversity' http://ec.europa.eu/ COMMFrontOffice/publicopinion/index.cfm/Survey/getSurveyDetail/ instruments/SPECIAL/surveyKy/2091
Work Day) has risen sharply from the first one in 2001 to around 14,000 in 2014 and has been stable ever since.

The number of volunteers submitting species counts to the website waarneming. $\mathrm{nl}$ has more than doubled in 10 years to 17,720 in 2017 and is still increasing. The number of garden bird counting participants has grown in 10 years from approx. 10,000 to more than 65,000 in 2018. The number of people clearing up rubbish is increasing. ${ }^{132}$

The government has taken several new steps to increase awareness and is planning to involve citizens, business

132 Boer, T.A. de, and F.L. Langers, 2017. Maatschappelijk draagvlak voor natuurbeleid en betrokkenheid bij natuur in 2017. Technical report 102, Wettelijke Onderzoekstaken Natuur \& Milieu, Wageningen. 
and industry (NV; NCA). For businesses, there is a programme of Green Deals to support bottom-up initiatives targeted at awareness raising, community and network building, experimentation and innovation. In the period from 2011 to 2018, 41 Green Deals for biodiversity involving around 200 participating parties were signed and presented on the website ${ }^{133}$ (per 1 May 2018). The Green Deal approach in the Netherlands is a low-threshold way for companies, other stakeholder organisations, local and regional governments and interest groups to work with the national government on green growth and social issues (see also section II-6).

Businesses are increasingly taking responsibility for raising awareness about biodiversity conservation and sustainable use. An example is the Leaders for Nature initiative initiated in 2005 by IUCN NL. ${ }^{134}$ In addition, the Platform on Business, Ecosystems and Economy (Platform BEE) founded by IUCN and the Confederation of Netherlands Industry and Employers (VNO-NCW) implemented an awareness raising programme to stimulate businesses to take action. This resulted in 2016 in The Hague Business Agreement on Natural Capital, which also marked the end of Platform BEE. ${ }^{135}$

One of the actions of the Natural Capital Agenda is the development of the digital Atlas of Natural Capital ${ }^{136}$ in the Netherlands. The Atlas provides information and tools for use by policymakers and civil society to raise awareness about natural capital, use it sustainably and find appropriate solutions, especially for the long term.

\section{Caribbean contribution to the achievement of Aichi Targets 1}

Healthy ecosystems such as coral reefs are critical to small island societies, such as Bonaire, Saba and Sint Eustatius. To make well-founded decisions it is important to understand how nature contributes to the economy and its wellbeing. This insight and awareness is crucial when managing the economy and nature of these islands. An analysis of the economic value of the main ecosystem services of these islands found that the total economic value (TEV) of the ecosystem services provided by the marine and terrestrial ecosystems are worth USD

\footnotetext{
133 https://www.greendeals.nl/

134 https://www.iucn.nl/actueel/terugblik-10-jaar-leaders-for-nature

135 https://www.iucn.nl/files/publicaties/den_haag_business_akkoord_voor_ natuurlijk_kapitaal.pdf

136 https://www.atlasnatuurlijkkapitaal.nl/
}

105 million annually for Bonaire, USD 29 million for Saba and USD 25 million for Sint Eustatius.

The studies demonstrated that it is more efficient to prevent extensive environmental damage by tackling current threats than it is to try and revitalise the environment while these threats continue undealt with. With the current threats unmanaged, the TEV of nature on these islands will decrease significantly. For Bonaire the TEV was estimated to decrease to less than $60 \%$ in 10 years' time and to less than $40 \%$ in 30 years' time. Scenarios based on managing roaming livestock, agricultural development and tourism expansion have been developed to simulate the change in the value of ecosystems over the next 30 years. The scenarios provide excellent input for welfare maximising development strategies and biodiversity awareness raising on the islands. The Bonairean study was accompanied by an award winning documentary.

The protected areas management organisations on each of the islands have dedicated CEPA and active programmes to educate young people in particular about nature. Nature conservation NGOs also play an important role in awareness raising. Boneiru Duradero focuses on awareness and community activity on Bonaire and is funded by the World Wildlife Fund (WWF) and the Ministry of Agriculture, Nature and Food Quality. The main focus is on reducing waste (plastics) via public campaigns and training. The campaigns reach many people via social media. ${ }^{137}$

On Sint Eustatius and Bonaire the national government funds dedicated communication/outreach programmes to increase awareness of nature on these islands. The Nature Awareness programme on Sint Eustatius organises a variety of workshops, signage, webcams, social media messages, after school programmes, exhibits and a youth ambassador programme. The Caribbean Netherlands Science Institute (CNSI) on Sint Eustatius offers space and an information centre/library for its outreach function. On Bonaire the nos ta biba di naturalesa (we live off nature) programme uses a website, social media and TV programmes and videos to highlight all activities on the island concerning nature and environment. ${ }^{138}$

A video of the Saba Bank National Park was produced showing the value of this unique area to the island as a

137 https://www.facebook.com/boneiruduradero/ 138 https://bibadinaturalesa.com/ 
major fisheries resource and the importance of using this resource sustainably. The video was shown on local TV and via social media. A shorter version was shown at a leading regional conference on fisheries and nature conservation. Local NGOs on Bonaire, Sea Turtle Conservation Bonaire (STCB) and the Echo Foundation have outreach and volunteer programmes to raise awareness and increase the involvement of local residents for sea turtles, the Bonaire parrot and reforestation.

\section{Aruba}

There are no studies on the awareness of biodiversity values among the local community. Nevertheless, the NGOs on the island are very active and provide regular information on a variety of topics. Active NGOs include Arikok National Park Foundation, Aruba Marine Park Foundation, Aruba Marine Mammal Foundation, TurtugAruba and Aruba Birdlife Conservation ( $A B C$ ). ABC launched a campaign to prevent illegal dumping, a campaign to prevent the extinction of the Choco, a burrowing owl, and a campaign on the impact of the invasive boa constrictor as well as field days to actually catch them.
In February 2016, the Ministry of Economic Affairs, Communication, Energy \& Environment, in cooperation with Setar N.V. (a private company, which provided funds through its corporate social responsibility programme), commissioned a TEEB study on the importance of nature for economic and social prosperity. This study was completed in January 2018 and can be considered an important step in biodiversity awareness raising.

\section{Curaçao}

There are no studies on the awareness of biodiversity values among the local community. Nevertheless, the NGOs of the island are very active and provide regular information on a variety of topics. Active NGOs include Amigoe di Tera, Defensa Ambiental, Carmabi, Uniek Curaçao and Sea Turtle Conservation Curaçao (STCC). These organisations actively engage the public. CARMABI Foundation runs a government funded school education programme reaching thousands of schoolchildren annually. Its Nature and Environment Programme consists of a Terrestrial Education Programme and a Marine Education Programme, including guided tours within the parks,

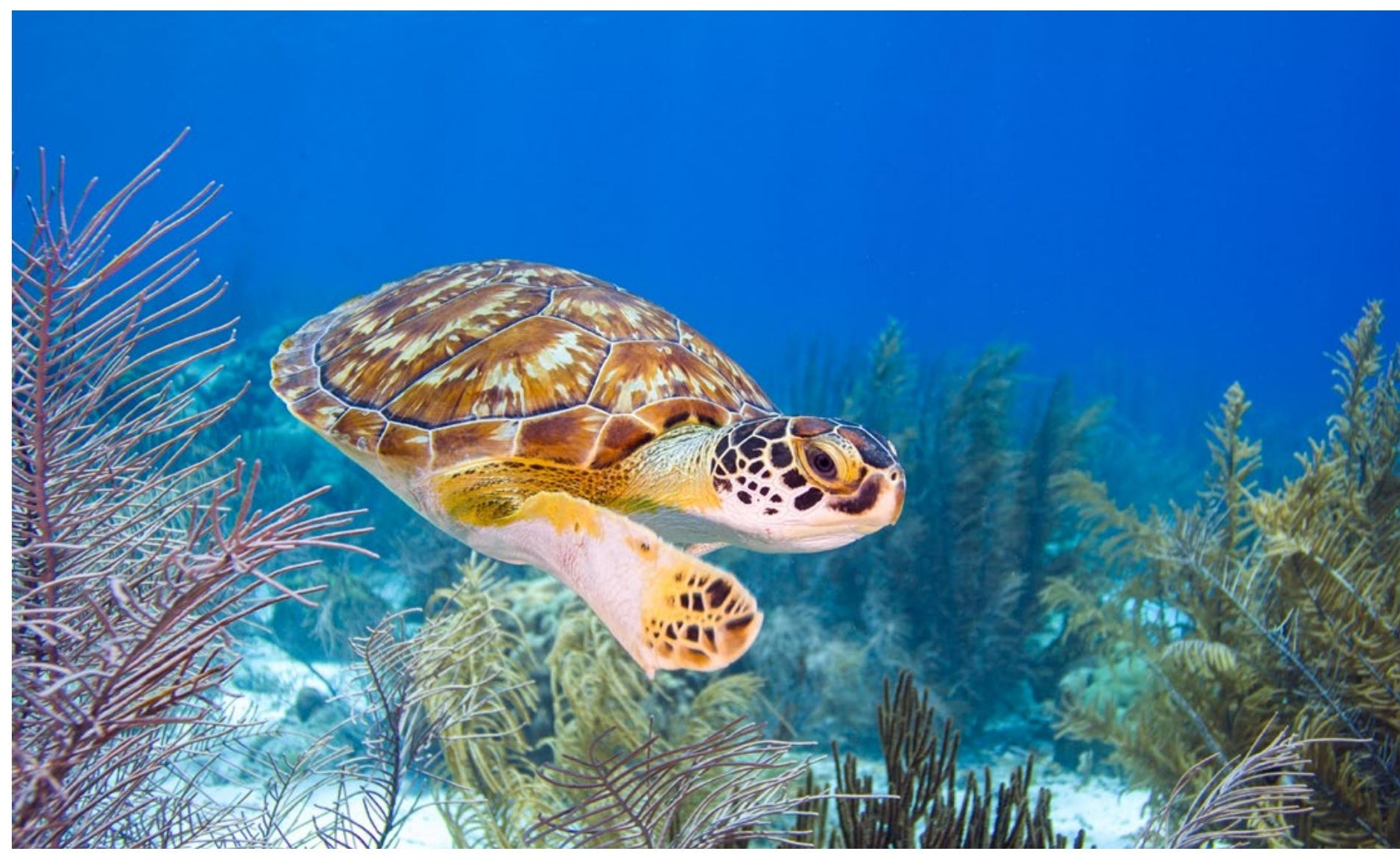


presentations, interactive exercises and a visit to the CARMABI Marine Education Center. In 2016, a total of 33 schools, including over 9,000 children, participated in the educational programmes. Uniek Curaçao runs an outreach programme to local businesses and civic groups, taking them on nature tours to let employees and social groups experience and appreciate the island's nature. They also publicise illegal rubbish dumping in nature areas to promote awareness, and organise regular clean-ups throughout the year.

STCC organises different activities to raise awareness about sea turtles and their protection. The organisation has an educational programme for schoolchildren and holds presentations for the general public, companies and tourists. They have installed informative signs on several public beaches about the turtles and the threats they face. They also hold public beach clean-ups on a regular basis. The plastic collected during these clean-ups is recycled. Hotels and the public support the lionfish control project. Biodiversity information in the native language (Papiamento) regularly appears in the newspapers and on national television. Although reasonable progress has been made on this target, the legal land use plan (Eilandelijke Ontwikkelings Plan), which is the only legal basis for designation of conservation areas, remains poorly understood and appreciated and is no match for the powerful landowner lobby.

\section{Sint Maarten}

Active NGOs on Sint Maarten are the Nature Foundation (NF), EPIC and SIMARC. The NGOs provide regular information on a variety of topics, host awareness workshops and pilot various environmental projects, such as the mangrove restoration project, Green Key auditing, certification and shark awareness week. From June 2017 to March 2018 the EPIC Foundation carried out a restoration project funded by the EU through the BEST 2.0 funding mechanism. The project focused on the restoration of biodiversity at three sites on Sint Maarten, two terrestrial sites and one coastal site. EPIC aimed to increase the appreciation for habitat restoration for biodiversity preservation by planting 500 trees and 300 red mangroves with student and community volunteers. The project supported schools and community groups by offering presentations and outdoor activities focusing on the importance of biodiversity. During the project, approximately 1,250 people participated in the various educational and volunteer opportunities. Hotels, dive operators and the general community support various conservation activities, including the management of the Marine Park Area (MPA), the coral restoration programme, shark conservation, terrestrial conservation and awareness incentives and the need for solid waste management. The Sint Maarten Nature Foundation is different from other NGOs in that they are designated as the Scientific and Ecosystem Authority of Sint Maarten, based on the Service Level Agreement that the NGO has with the Government of Sint Maarten.

\section{Dutch contribution to the achievement of Aichi Targets 1 at a global level}

Public opinion is an important factor in influencing politicians and decision makers and awareness of the importance of biodiversity provides public support for policy to conserve biodiversity nationally and internationally. Most Dutch citizens have a medium to high level of awareness of the importance of nature conservation. 
By 2020 , at the latest, biodiversity values have been integrated into national and local development and poverty reduction strategies and planning processes are being incorporated into national accounting, as appropriate, and reporting systems.

\section{Why is this target important?}

One of the persistent challenges related to the conservation and sustainable use of biodiversity is to include it as a significant consideration when decisions are being taken on economic development and reducing poverty. Without such 'mainstreaming', the best conservation measures can be jeopardised as development activities may threaten habitats and contribute to other pressures on biodiversity. A key step towards meeting this challenge is to ensure that the values of biodiversity to economies and livelihoods, often ignored in conventional accounting, are incorporated into the strategies and processes that drive decisions about development ${ }^{139}$.

\section{Summary of progress towards the target}

Biodiversity values have been integrated into national and local development strategies and planning processes and are being incorporated into national accounting, as appropriate, and reporting systems. The progress made on Aichi Targets 2 can be considered to be relatively high. Progress towards Aichi Targets 2 in the Caribbean Netherlands is assessed as 'on track to achieve target'. Aruba and Sint Maarten are assessed as 'progress towards target but at an insufficient rate' and Curaçao is assessed as 'no significant change'.

\section{Dutch contribution to the achievement of \\ Aichi Targets 2}

In the National Policy Strategy for Infrastructure and Spatial Planning (SVIR), the Dutch government identifies conservation and protection of species as an important national interest. The government continues to develop the national ecological network (NEN) as the most important instrument for halting biodiversity loss. The 'no,

139 Global Biodiversity Outlook A mid-term assessment of progress towards the implementation of the Strategic Plan for Biodiversity 2011-2020 unless' development control regime for the NEN protects nature within the network against development with negative impacts. Under this regime there was only a small increase in new housing within the boundaries of the NEN between 2000 and $2017^{140}$. Regional governments have incorporated the NEN into their spatial plans since around 1995. Local governments are the competent authorities for permitting development. In their local development plans they have to weigh the economic and social values of development proposals against ecological values. Where spatial information on protected species requires it, they make mitigation and compensation measures a condition on permission for building and other development.

All development plans must take existing biodiversity values into account and are subject to an environmental impact assessment. The government encourages the inclusion of measures to create or restore habitats in development plans in combination with other functions, such as climate change adaptation, drinking water supply, redesigning tourism infrastructure, urban development, infrastructure investment and flood protection. An example of such integrated planning is the Room for the River programme. The measures to manage higher discharge levels have also been designed in such a way that they improve the ecological, landscape and recreational quality of the immediate surroundings (see section IV-2).

\section{National accounting and reporting systems}

Examples of national accounting and reporting systems with biodiversity indicators:

- The Netherlands Commission for Environmental Assessment (NCEA) reviews all environmental impact assessments of spatial plans and makes recommendations. They issued 159 recommendations in 2016 and 168 in 2017, half of which were mandatory advisory reviews of environmental impact statements (EISs). The Commission found significant shortcomings in $70 \%$ of the EISs they reviewed, compared with $63 \%$ in 2016 and $66 \%$ in 2015. In particular, information was lacking on the effects on Natura 2000 areas and on possible alternative, environmentally friendly solutions (NCEA Annual Report 2017 $7^{141}$ ). In half of these cases, the competent authority later reviewed the EISs again and $80 \%$ of them had been revised and were complete.

140 http://www.clo.nl/indicatoren/

nl2050-bouwen-in-natuurgebieden-in-de-ecologische-hoofdstructuur 141 https://www.commissiemer.nl/jaarverslag2017/ 
- Between 2007 and 2017 the provincial governments informed parliament each year on the progress being made with establishing the $\mathrm{NEN}^{142}$.

- Once every two years, the Netherlands Environmental Assessment Agency (PBL) reports on the state of the environment and evaluates policy, including on biodiversity and nature. ${ }^{143}$

\section{Caribbean contribution to the achievement of Aichi Targets 2}

TEEB studies on all three islands have revealed that the island economies and welfare very much depend on healthy ecosystems. Mainstreaming biodiversity in all sectors is crucial for the islands. It is one of two main targets of the Caribbean Netherlands Nature Policy Plan 2013-2017 ${ }^{144}$, and includes 17 strategic actions. An overview of the results of these actions cannot be provided, however, as an assessment has not yet been carried out. A draft Nature Policy Plan has been prepared.

\section{Aruba}

Aruba's government has set itself the goal of moving towards sustainable development, which in essence means balancing three interconnected areas: social welfare, economic responsibility and ecological resilience. In order to make sound decisions about the management of ecosystems, it is necessary to estimate the socioeconomic value that these ecosystems provide to Aruba and incorporate natural capital into policymaking. In February 2016, the Ministry of Economic Affairs, Communication, Energy \& Environment commissioned a TEEB study (co-funded by Setar N.V.) on the importance of Aruban nature for economic and social prosperity. This study, completed in 2018, can be considered an important step towards the development of a sustainable island economy on Aruba.

\section{Curaçao}

A few small studies provide partial assessments of the economic value of biodiversity and parks, but no integrated assessment has been made. The tourism masterplan 2015-2020 did not include biodiversity values, even though tourism is highly dependent on biodiversity.

\section{Sint Maarten}

An economic valuation of the country's coral reef resources was completed in 2010 and 2015 (T. Bervoets, Nature Foundation) and was used to establish the country's first Marine Park and only protected area. A subsequent assessment in 2014 (T. Bervoets, Nature Foundation) was also used to determine the goods and services provided by the Mullet Pond Wetland, which was subsequently identified as a Ramsar site. Also, eight shark species were added under the international SPAW Protocol (on Specially Protected Areas and Wildlife), the only cross-border legislative instrument for nature conservation in the Wider Caribbean Region.

\section{Dutch contribution to the achievement of Aichi Targets 2 at a global level}

Biodiversity values and sustainable production are integrated into Dutch development policy and trade. ${ }^{145}$ The Netherlands takes part in the World Bank led WAVES programme to promote natural capital accounting methods and including natural capital values into national accounts and statistics. 


\section{Target 3 \\ Incentives reformed}

\author{
By 2020, at the latest, incentives, including subsidies, \\ harmful to biodiversity are eliminated, phased out or \\ reformed in order to minimise or avoid negative impacts, \\ and positive incentives for the conservation and sustaina- \\ ble use of biodiversity are developed and applied, consist- \\ ent and in harmony with the Convention and other \\ relevant international obligations, taking into account \\ national socioeconomic conditions.
}

\section{Why is this target important?}

Incentives created by government regulations and programmes have a powerful influence on behaviour affecting biodiversity, from private individuals to large corporations. A well-designed system of positive incentives can encourage better stewardship of land, inland waters and oceans; conversely, the best conservation policies can easily be undermined by incentives that encourage overexploitation of resources. Reforming these incentives is critical to addressing the underlying causes of biodiversity loss ${ }^{146}$.

\section{Summary of progress towards the target}

The progress made towards Aichi Targets 3 so far has been limited. While there have been positive developments, such as greener taxation and tax incentives for sustainable livestock housing systems, important incentives harmful to biodiversity, such as the low rate of VAT on milk, meat and kerosene, have not been phased out or reformed. Progress towards Aichi Targets 3 in the Caribbean Netherlands, Aruba is assessed as 'progress towards target but at an insufficient rate'. Progress towards Aichi Targets 3 in Curaçao and Sint Maarten is assessed as 'no significant change'.

\section{Dutch contribution to the achievement of \\ Aichi Targets 3}

The Netherlands has a relatively green tax system. In 2016 revenues from green taxes were EUR 20.6 billion, $3.3 \%$ more than in 2015 (Figure 26). Revenues have increased by $43.7 \%$ since 2001 . In 2016 total revenues to the Dutch government amounted to EUR 165.6 billion, of

146 Global Biodiversity Outlook A mid-term assessment of progress towards the implementation of the Strategic Plan for Biodiversity 2011-2020 which $12.5 \%$ were from green taxes (CBS et al., 2017). Businesses that invest in environmentally friendly means of transport and farmers who invest in sustainable livestock housing can claim tax relief. The number of sustainable livestock sheds is increasing (Figure 27).

In the letter to parliament 'Green Growth: For a Strong, Sustainable Economy' 147 the government sets out its policy on smart use of market incentives. The prices of goods and services should increasingly reflect the external impacts of production and consumption on nature and the environment. A smart combination of pricing (for example via taxation and the EU Emissions Trading Scheme), innovation policy and selective public procurement will promote more sustainable production and will create markets for sustainable products and services.

Existing environmentally harmful subsidies and tax exemptions have unintended negative effects on nature and the environment. Abolishing these environmentally harmful subsidies could not only deliver substantial savings, but also help towards cleaning up the environment. In 2010 the Netherlands provided large environmentally harmful subsidies and tax breaks, particularly in the energy, transport and agricultural sectors ${ }^{148}$. The Dutch government could abolish national environmentally harmful subsidies, but for competition reasons this would require agreements at the European or global scale.

Examples are subsidies and tax breaks on kerosene (aviation) and the low VAT tariffs on meat, dairy and fish $^{149}$. The tax break on red diesel was abolished on 1 January 2013, with the exception of ships other than recreational vessels. In addition, the abolition of the European milk quota system in 2015 has led to an increase in agricultural production in the Netherlands. Given the negative relationship between this increase and biodiversity ${ }^{150}$ (Kleijn, 2013), a negative impact on biodiversity is expected to occur if no compensation or mitigation measures are taken. The Dutch manure policy has been tightened to mitigate the effects of an increase in agricultural production.

147 https://zoek.officielebekendmakingen.nl/kst-33043-14.html

148 PBL, 2011. Note Environmentally harmful subsidies. Planbureau voor de Leefomgeving (PBL), Den Haag/ Bilthoven. PBL Publication number 500209002

149 PBL, 2011. Note Environmentally harmful subsidies. Planbureau voor de Leefomgeving (PBL), Den Haag/ Bilthoven. PBL Publication number 500209002; https://www.rli.nl/publicaties/2018/advies/duurzaam-en-gezond 150 Kleijn, D., 2013. De effectiviteit van Agrarisch Natuurbeheer. Alterra: 23p. 


\section{Green taxes revenues}

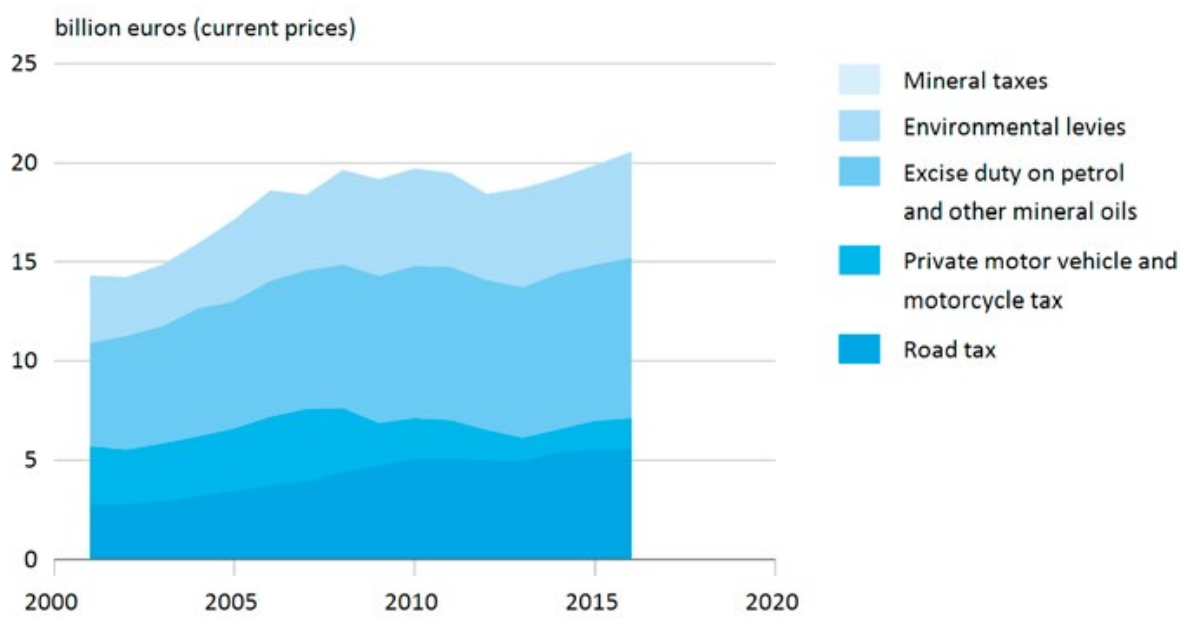

ource: CBS

Figure 26. Trend in green tax revenues in the Netherlands

\section{Sustainable stables}

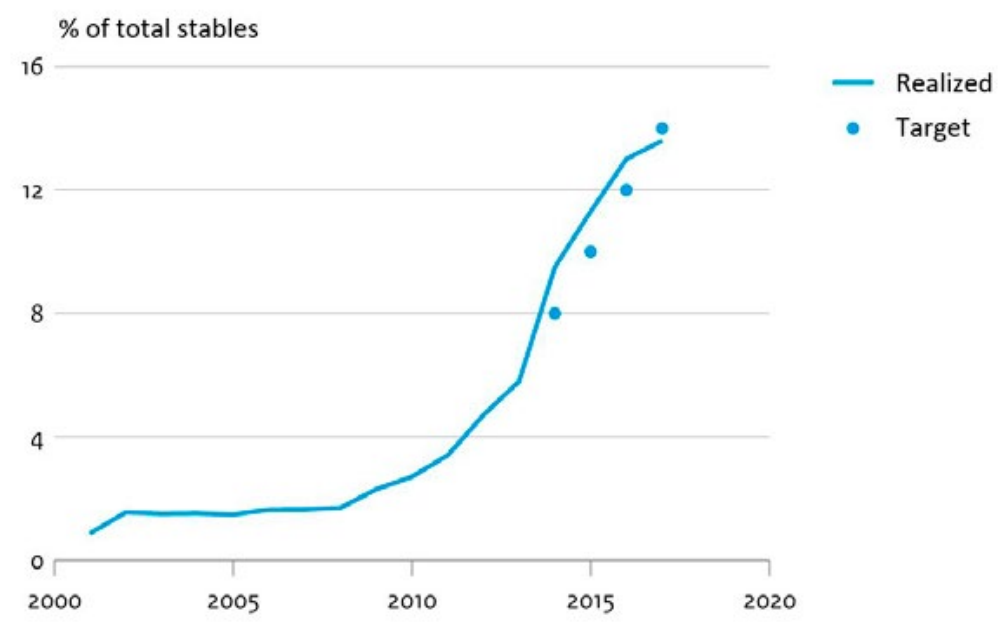

Bron: WUR

Figure 27. Trend in sustainable livestock sheds in the Netherlands

The Netherlands puts a high priority on greening the EU common policies on agriculture and fisheries to eliminate, phase out or reform incentives that are harmful to biodiversity and introduce positive incentives. Time will show if this strategy has been effective.

\section{Caribbean contribution to the achievement of} Aichi Targets 3

The Nature Policy Plan for the Caribbean Netherlands 2013-2017 $7^{151}$ aims to mainstream nature conservation and

151 https://www.government.nl/documents/publications/2014/02/03/ nature-policy-plan-the-caribbean-netherlands 
sustainable use in all sectors of society, including support for the development of sustainable agriculture on the islands. This will require the reform of incentives with harmful consequences for biodiversity. Under the Nature Policy Plan (NPP), funding was made available to provide positive incentives to the islands to improve conservation and the sustainable use of biodiversity and various projects were executed. National Park fees to dive and snorkel are paid only by stay-over tourists, not by cruise ship visitors. Introducing a park fee for cruise ship tourists will provide positive incentives to better inform this group and increase opportunities to maintain the Marine Park. On a smaller scale, various projects were carried out under the Bonaire community training and awareness programmes via Boneiru Duradero, funded by WWF, including citizen science related to waste monitoring and reduction (e.g. trash for cash project).

\section{Aruba}

A tax incentive on energy efficient goods (among others hybrid cars and electric cars) came into force in January 2011 and a ban on plastic bags came into force in January 2017. In August 2017 legislation protecting local endangered flora and fauna came into force and the old Marine Environment Protection law was repealed. The fines on prohibited handlings were incremented.

\section{Curaçao}

No negative incentives have been reformed and no positive incentives have been developed and applied.

\section{Sint Maarten}

A part of the application of the Marine Park Management Plan is the inclusion of user fees to be able to access the MPA for non-resident users of the site. Dive operators are required to inform the Nature Foundation for the payment of the fee and are policed by the foundation. Noncompliance with the fee can result in a prohibition on usage of the MPA.

\section{Target 4 \\ Sustainable production and consumption}

\section{By 2020, at the latest, governments, business and stakeholders at all levels have taken steps to achieve or have implemented plans for sustainable production and consumption and have kept the impacts of use of natural resources well within safe ecological limits.}

\section{Why is this target important?}

Underlying all the direct pressures on biodiversity is the unsustainable demand for natural resources generated by our present patterns of producing and consuming goods and services. As the human population and per capita consumption increase, such pressures can only increase unless there is a determined effort to make production and consumption more sustainable. To meet the objective of keeping the impacts of natural resource use well within safe ecological limits, actions must address the efficiency of using resources and limit total demand for goods and services $^{152}$.

\section{Summary of progress towards the target}

Reasonable progress has been made towards Aichi Targets 4 , but at an insufficient rate. Major steps have been taken to keep the impacts of the use of natural resources within safe ecological limits, although concern still remains about the reform of the agricultural sector and the ecological footprint of the Netherlands, especially abroad (see also section IV-6). The path to sustainability is long. Progress towards Aichi Targets 4 in the Caribbean Netherlands is assessed as 'progress towards target but at an insufficient rate'. The progress in Aruba, Curaçao and Sint Maarten is assessed as 'no significant change'.

\section{Dutch contribution to the achievement of Aichi Targets 4}

Aichi Targets 4 is fundamental for achieving other Aichi Targets and is the basis for the policy strategy on biodiversity. Measures are being taken to make consumption and production in relevant sectors like agriculture, forestry and fisheries more sustainable. The aim of the Natural Capital Agenda is sustainable agriculture, fisheries

152 Global Biodiversity Outlook A mid-term assessment of progress towards the implementation of the Strategic Plan for Biodiversity 2011-2020 


\section{Organic farming}

Acreage per crop

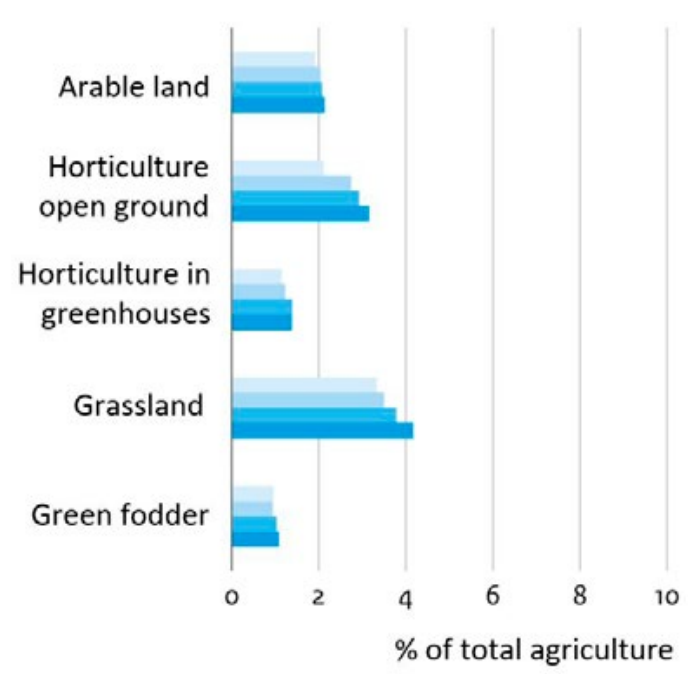

2011 The number includes farms in

2015 conversion

2016

2017

\section{Bron: CBS}

Figure 28. Percentage organic farming per crop and per animal species

and forestry by 2020 . Under the policy for a circular economy, the transition agenda on biomass and food was launched in 2018. This agenda includes promoting more sustainable and healthy consumption patterns, especially for food products. ${ }^{153}$

Governments, businesses and stakeholders at all levels are taking steps to achieve sustainable production and consumption. The market shares of a number of biotic natural resources imported into the Netherlands with a sustainability label have increased substantially in recent decades (see Figure 23 in section IV-6). Market-wide agreements are needed at a European level to stimulate sustainable trade and to create a level playing field between Member States. The Netherlands has an active role in this. An example is the Amsterdam Palm Oil Declaration for the use of sustainable palm oil, which was

153 https://www.circulaireeconomienederland.nl/transitieagendas/transitieagenda +biomassa+en+voedsel/ default.aspx
Number per animal species

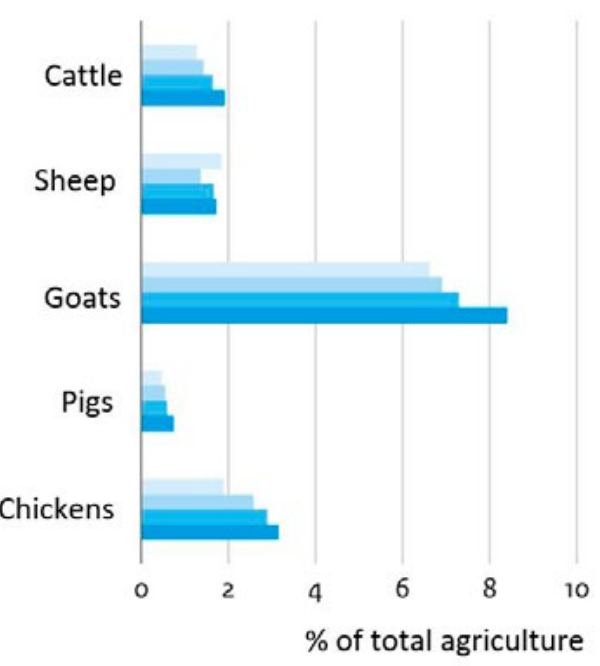

CBS/jan18
www.clo.nl/nlooins

adopted by several EU Member States during a conference on sustainable trade in 2016.

\section{Organic agriculture}

Organic farming is considered a promising strategy for making agricultural and horticultural production more sustainable. In 2017, just 3.1\% of all Dutch farmland was under organic farming. In comparison with other European countries, the organic farming sector in our country is small ${ }^{154}$, but it is growing. Between 2011 and 2018, the area under organic farming increased by $19 \%$ from 47,000 to 58,000 ha $^{155}$. This growth mainly took place in the area of grassland (23\%) and open field horticulture (61\%). In 2017 the organic farming area was 3\% larger than in the previous year.

\footnotetext{
154 https://ec.europa.eu/eurostat/statistics-explained/index. php?title=File:Organic_farming_area_EU_and_EFTA.rev.jpg 155 https://www.clo.nl/indicatoren/nl0011-biologische-landbouw
} 


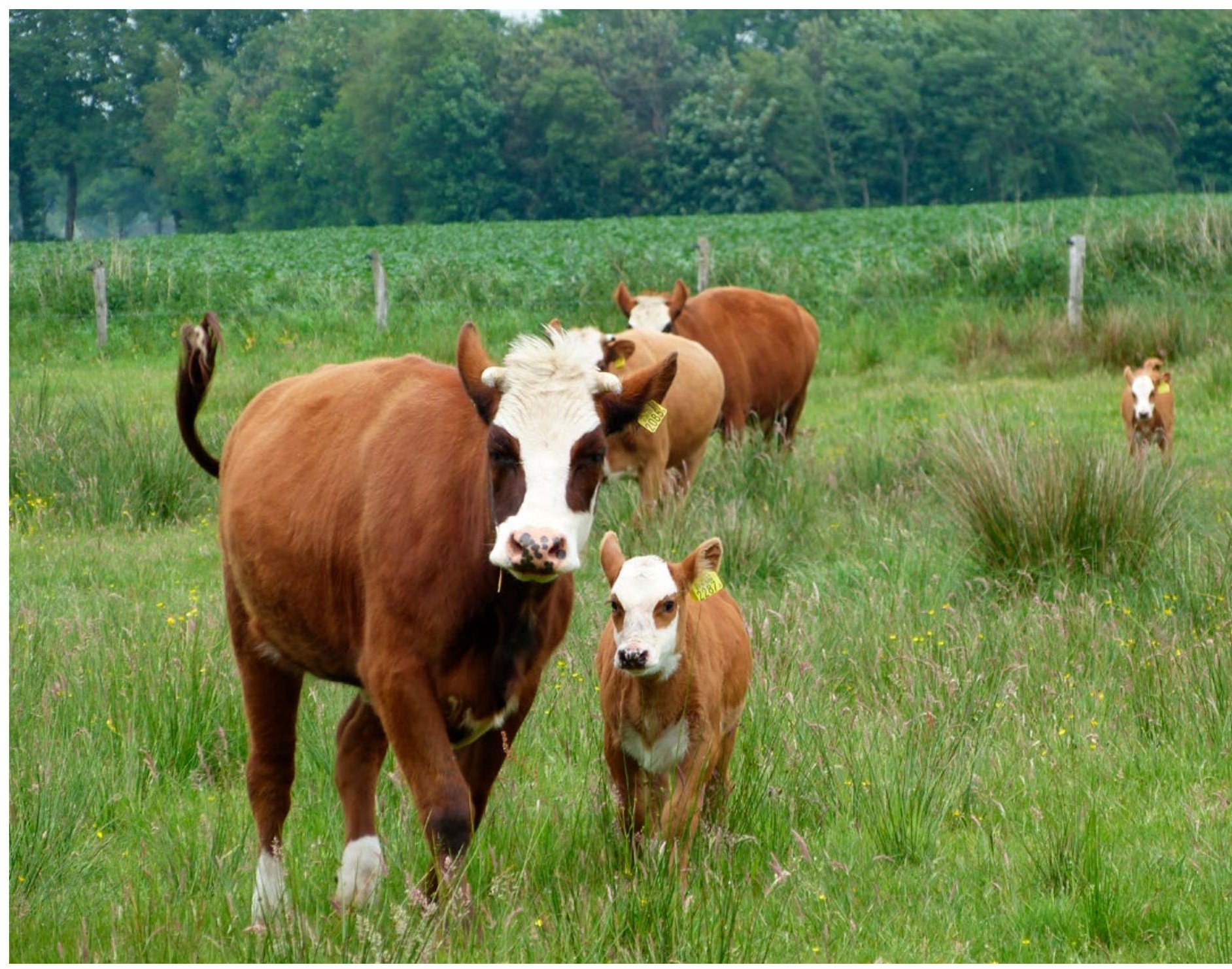

\section{Monitor sustainable food}

Total consumer spending on sustainable food examined in a sample of stores and other outlets (supermarkets, specialist sustainable food shops and hospitality and food service outlets) amounted to EUR 4.5 billion in 2017: a $19 \%$ increase on $2016^{156}$. The proportion of sustainable food as a percentage of total expenditure on food rose from $10 \%$ in 2016 to $11 \%$ in 2017 . A large proportion of the raw materials consumed in the Netherlands are produced abroad.

\section{Caribbean contribution to the achievement of Aichi Targets 4}

Overfishing is still a major concern in the Caribbean Netherlands. Monitoring data on fish populations are scarce. Fisheries monitoring of the Saba Bank and Saint Eustatius started in 2013 to inform the introduction of sustainable fisheries management. The Netherlands has teamed with WWF in a programme on Bonaire to bring

156 https://www.agrimatie.nl/ThemaResultaat.

aspx?subpubID $=2232$ \& themaID $=2810$ \&indicatorID $=2659$ together the various initiatives and strengthen the drive towards sustainability. Agriculture and horticulture on all the islands is small-scale, although thousands of farm animals (goats, cows, donkeys, pigs) roam freely. This has a major impact on not only the terrestrial but also the marine biodiversity, as erosion of overgrazed soils leads to sedimentation of marine habitats. Restricting free-roaming livestock has social implications, however, and solutions remain limited. Some recent developments are:

- a joint effort on Bonaire by the NGO Stinapa and the island government, with Dutch funding (Groenfonds), to reduce the goat population in the Washington Slagbaai National Park;

- a joint effort on Bonaire by the island government, local stakeholders and Wageningen University to develop sustainable agriculture and animal husbandry on the island;

- implementation of a programme on Sint Eustatius by the department of Agriculture, Animal husbandry and Fisheries (LVV) to enclose free-roaming donkeys and improve cattle management to greatly reduce the number of free-roaming cattle; 


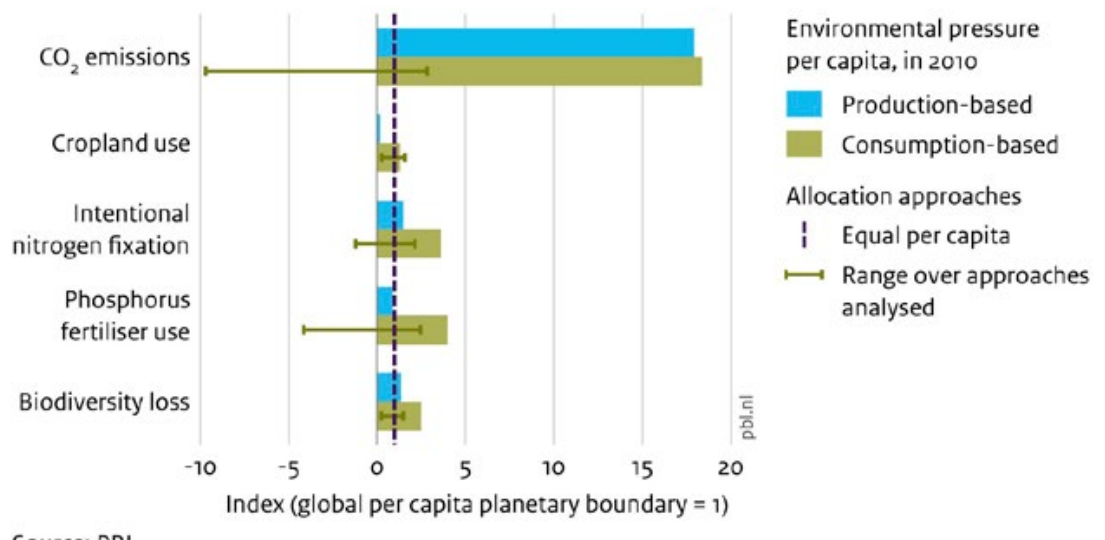

Source: PBL

Figure 29. Dutch environmental pressures compared to allocated planetary boundaries

\section{Sint Maarten}

Natural resources are limited. The island economy depends heavily on imports and tourism. The company responsible for generating electricity is still reliant on fossil fuels. Efforts are being made to introduce energy saving measures and develop renewable energy sources.

A National Energy Policy has been approved which lists the top sustainable energy priorities and details a plan of approach to implement the energy policy.

\section{Dutch contribution to the achievement of}

\section{Aichi Targets 4 at a global level}

A large proportion of Dutch consumer goods are produced abroad. Almost all activities promoting sustainable production and consumption are contributing towards the Aichi Targets at the global level.

\section{Living within planetary boundaries}

Setting global quantitative targets where they currently do not exist involves normative decisions related to risk acceptance, solidarity and precaution. The planetary boundaries framework and the related literature can help in setting such targets. National responsibility for global environmental pressure and impacts can be determined from either a production or consumption perspective (footprint), taking into account the whole value chain. Dutch environmental footprints per capita are much larger than the global average. Furthermore, a large share of the environmental pressures beyond national borders relates to agriculture in other countries, such as cropland use, nutrient pollution and biodiversity loss. Despite the large range resulting from alternative allocation approaches, most allocation results are lower than the current Dutch environmental footprints. It can therefore be concluded that the Netherlands is not living within its safe operating space (Figure 29). ${ }^{157}$ 


\title{
Strategic Goal B
}

\author{
Reduce the direct pressures on biodiversity and promote sustainable use
}

\section{Target 5 \\ Habitat loss halved or reduced}

By 2020, the rate of loss of all natural habitats, including forests, is at least halved and where feasible brought close to zero, and degradation and fragmentation is significantly reduced.

\section{Why is this target important?}

The destruction and degradation of natural habitats is the single most important driver of biodiversity loss.

Economic, demographic and social pressures are likely to lead to continued conversion of habitats, but reducing the rate of that loss is critical to implementing the Strategic Plan for Biodiversity 2011-2020. Preventing further fragmentation of habitats is also essential to avoid species populations becoming isolated and to enable essential movements across landscapes and aquatic environments. This is especially important in the face of climate change ${ }^{158}$.

\section{Summary of progress towards the target}

Reasonable progress has been made on all aspects of Aichi Targets 5. Progress is being made with reversing habitat loss and habitat fragmentation has been significantly reduced (see also section III-1). However, significant reduction of degraded areas largely depends on reducing environmental pressures from agriculture. Progress towards Aichi Targets 5 in the Caribbean Netherlands, Aruba, Curaçao and Sint Maarten is assessed as 'moving away from target'.

\section{Dutch contribution to the achievement of Aichi Targets 5}

The ongoing development of the NEN (main measure III-1) has led to defragmentation of habitats and has

158 Global Biodiversity Outlook A mid-term assessment of progress towards the implementation of the Strategic Plan for Biodiversity 2011-2020 reversed habitat loss and increased the area of new habitat. Since 1990 approx. 85,000 ha of new habitat has been created, of which 33,000 ha between 2011 and $2017^{159}$. For more than half of the characteristic species, however, these habitats are still too small in size to support sustainable species populations (see Figure 30 ). Ecological barriers caused by national transport infrastructure have been removed through the implementation of mitigation measures, such as wildlife crossings (Figure 4, section III-1). The same has been done for aquatic biodiversity. Migratory fish species are increasingly able to migrate between marine and freshwater habitats due to the construction of fish passages at barriers such as dams and pumping stations (see Figure 5, section III-1). Many more fish passages are planned for construction.

In general, habitat loss due to degradation has been significantly reduced. Specific habitats like heathland and farmland, however, have not improved but continue to deteriorate (see farmland bird index Aichi Targets 7 and LPI Aichi Targets 12) mainly due to environmental pressure (Aichi Targets 8). Many habitats still suffer from a combination of desiccation and excessive nitrogen deposition.

\section{Caribbean contribution to the achievement of Aichi Targets 5}

Bonaire and Sint Eustatius each have zoning regulations identifying conservation areas and prohibiting any development in such areas. Saba has not yet implemented a zoning plan, but has limited development to a maximum altitude, safeguarding most of the natural areas from degradation. In September 2018 Saba took a major step forward by designating $25 \%$ of the island, including all land above $550 \mathrm{~m}$ and most of the northern quadrant of the island, as protected nature park. Despite these zoning plans, the impacts of threats like overfishing, grazing livestock, invasive species, climate change, etc. is substantial. The state of nature in the Caribbean Netherlands

159 http://www.clo.nl/en/indicators/en1307-new-ehs-acquisition-anddevelopment; IPO Derde voortgangsrapportage Natuur 


\section{Suitability of spatial conditions for terrestrial ecosystems}

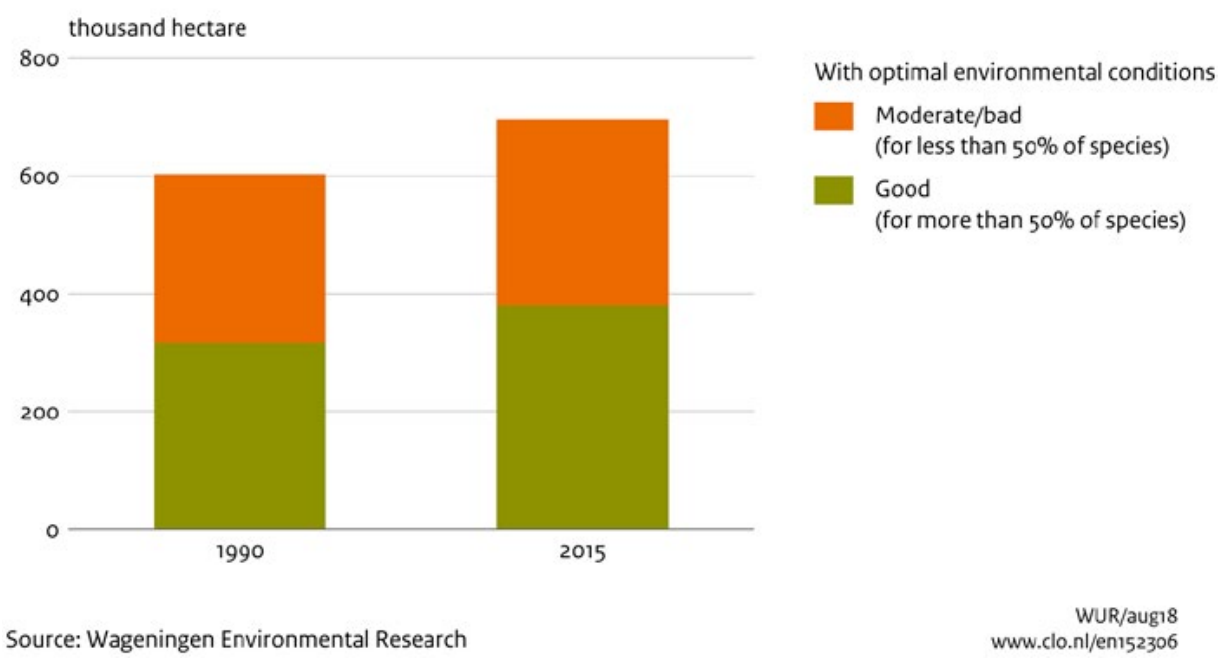

Figure 30. Suitability of spatial conditions for terrestrial ecosystems

\section{Conservation status of species and habitats}

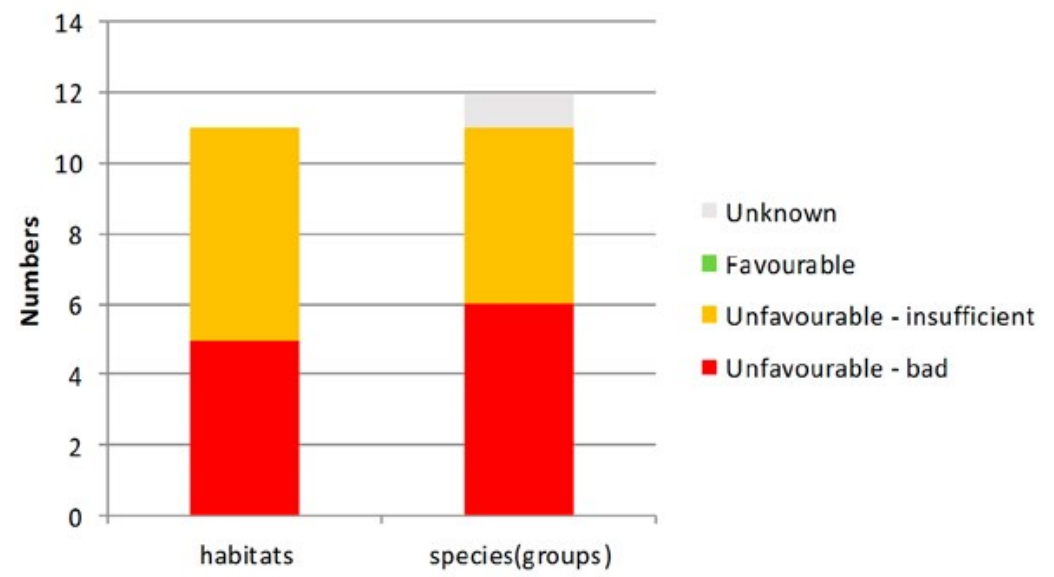

Figure 31. Conservation status of 11 marine and terrestrial habitats and 12 species/species groups in 2017 (Debrot et al., 2018)

was assessed in 2017 (Debrot et al., 2018) and the conservation status of all habitats was assessed as unfavourable-insufficient or unfavourable-bad (Figure 31). The same was true for all the assessed species or species groups that depend on these habitats. Moreover, the 2017 hurricane season has had a substantial impact on the terrestrial and marine habitats of Saba and Sint Eustatius.

\section{Aruba}

The Physical Development Policy 2009 addresses covers urban development and nature conservation areas, but the policy has yet to be implemented. The legal designation of Arikok National Park as protected habitat by ministerial decree in 2000 represents a major achievement towards habitat protection. In 2012, the parliament of Aruba unanimously approved a motion to expand Arikok National Park with the inclusion of 16 terrestrial and 
marine sites. The Spanish Lagoon Ramsar site, a coastal bay and wetland area, was already annexed to the Arikok National Park in February 2017 and restoration works were carried out. The development of a nature network to create ecological corridors between habitats is provided for in the Nature Policy Plan of Aruba, but has not been implemented yet. The 2016 Marine Mammal Action Plan prepared by Aruba Marine Mammal Foundation (AMMF), which includes locally observed threats and mitigation proposals to the Aruba government, was submitted in June 2018.

\section{Curaçao}

Little progress has been made towards this target. The 1997 land use and zoning law was an important step towards protecting the terrestrial ecosystem, but pressures on the marine and coastal environment continue to grow. Curaçao has not yet met the obligations contained in its Nature Conservation Act (Landsverordening Grondslagen Natuurbeheer), including the implementation of regulations on protected species, protected areas and measures against invasive species.

\section{Sint Maarten}

Habitat loss is still occurring at an alarming rate and this trend will only be changed through the implementation of pending legislation. The recognition of the importance of biodiversity, the support for biodiversity actions, the inclusion of sustainable development in country plans, the inclusion of mandatory environmental impact assessments, the strengthening of capacity for inspections and enforcement of environmental legislation, and the increase in capacity to address environmental challenges in the short, medium and long term are all critical to ensure the reduction in habitat loss. Article 20a in the EROP (Eilandsverordening Ruimtelijke Ontwikkelingsplanning Sint Maarten), which states that any cutting or development of roads in the hillsides needs a civil/infrastructure works permit, has expired. This means that key biodiversity areas can be affected or even destroyed. Uncontrolled development in the hillsides can lead to fragmentation and erosion. In addition to above, hurricanes Irma and Maria in 2017 have had a substantial impact on terrestrial and marine habitats.

\section{Target 6 \\ Sustainable management of aquatic living resources}

By 2020, all fish and invertebrate stocks and aquatic plants are managed and harvested sustainably, legally and applying ecosystem-based approaches, so that overfishing is avoided, recovery plans and measures are in place for all depleted species, fisheries have no significant adverse impacts on threatened species and vulnerable ecosystems and the impacts of fisheries on stocks, species and ecosystems are within safe ecological limits.

\section{Why is this target important?}

Overexploitation of fish and other marine and inland water organisms is a significant pressure on biodiversity. Unsustainable harvesting threatens not just marine and inland water biodiversity, but the profitability of fishing businesses around the world and the livelihoods of millions dependent on the resources of the ocean and inland waters. Finding and applying management approaches that avoid unsustainable fishing practices and that enable stocks to recover are therefore essential elements in a strategy to conserve and sustainably use biodiversity ${ }^{160}$.

\section{Summary of progress towards the target}

Reasonable progress has been made towards Aichi Targets 6 (section IV-4). Further progress depends to a great extent on the implementation of the CFP from 2014 onwards. Progress towards Aichi Targets 6 in the Caribbean Netherlands, Curaçao and Sint Maarten is assessed as 'progress towards target but at an insufficient rate'. Progress in Aruba is assessed as 'no significant change'.

\section{Dutch contribution to the achievement of \\ Aichi Targets 6}

The European Union is responsible for policies for the management of marine living resources in Europe and countries where European fisheries operate and these are contained in the CFP. The new CFP entered into force in 2014. Furthermore, parts of the Natura 2000 areas (North Sea Coastal Zone and the Vlakte van Raan) are closed to

160 Global Biodiversity Outlook A mid-term assessment of progress towards the implementation of the Strategic Plan for Biodiversity 2011-2020 


\section{Biodiversity North Sea}
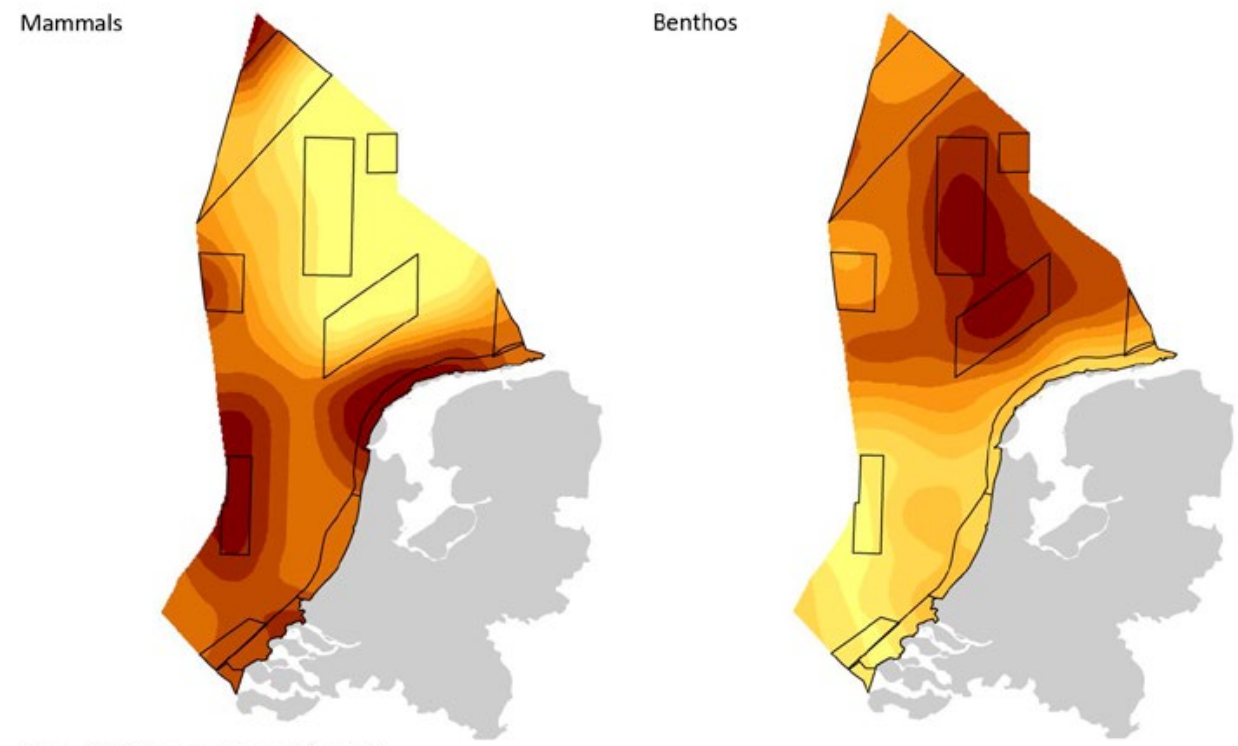

Number of species (index)

Bron: RWS; Imares; Bewerking PBL

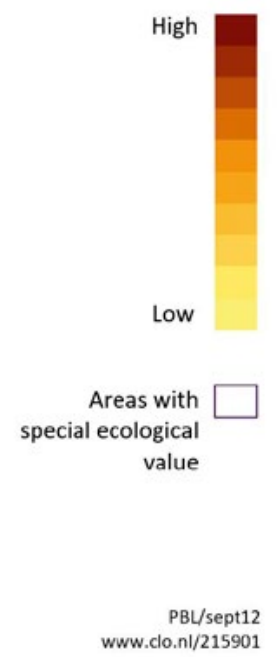

Figure 32. Biodiversity of marine mammals and benthos in the North Sea and the areas with special ecological value (Natura 2000 sites)

forms of fishing that have an impact on soil life or can disturb sea mammals and birds (VIBEG agreement, see Figure 32).

The most important fish stocks (herring, plaice, sole) are above safe biological limits and also above sustainable levels. Cod is not yet above the sustainable level (Figure 17 and 18, section IV-4). However, not all the effects of unsustainable fisheries have been restored. Vulnerable long-lived shark and ray species are still critically endangered or threatened (Figure 19, section IV-4). Many species of benthos have decreased in numbers since 1990 and recovery has not yet been determined (Figure 20, section IV-4). The Netherlands has a shark and ray recovery action plan 2015-2021 under the EU Marine Strategy Framework Directive. The measures related to the Marine Strategy Framework Directive are currently being implemented in order to conserve marine biodiversity. According to the Marine Strategy (part 1, 2018-2024), the good environmental status of biodiversity based on OSPAR indicators has not been reached, but the environmental status for biodiversity is improving (see section IV.4)

\section{Caribbean contribution to the achievement of Aichi Targets 6}

Since 2011 the biodiversity and fisheries resources of the waters surrounding the islands of the Caribbean Netherlands, from the outer borders of the marine protected areas surrounding the islands to the outer borders of the Exclusive Economic Zone, have been jointly managed under a Memorandum of Agreement (MoA) between the islands and the Netherlands. Fisheries monitoring programmes have been initiated on the Saba Bank, Sint Eustatius and Bonaire to develop effective ecosystem-based management. Fisheries are managed through permit requirements for all fishing boats in the Exclusive Economic Zone (EEZ) waters and for boats larger than $12 \mathrm{~m}$ in the territorial waters of each of the islands. Regulations are in place for minimum sizes of lobster and conch, requirements for various types of fishing gear and prohibiting destructive fishing methods. A roadmap towards improved and updated fisheries regulations has been initiated and the first step of evaluation of the current fisheries regulations has been completed. Stakeholder consultations are ongoing to discuss the recommendations of the evaluation and decide on their implementation. In 2015 the Yarari Sanctuary for marine mammals and sharks was declared for the waters of 
Bonaire and Saba. In 2018 Sint Eustatius decided to join in the Yarari Sanctuary, and Sint Maarten also indicated it was prepared to join in the Sanctuary.

\section{Aruba}

Aruba also has some fisheries laws in place but no recent advances have been made in terms of measures towards sustainable management of marine resources. The Minister of Spatial Development, Infrastructure and Environment and WWF Netherlands held workshops and a mini symposium on Marine Parks and the Blue Economy on 6-8 June 2018 .

\section{Curaçao}

Fisheries legislation is in place to reduce or prohibit some of the most destructive gear and practices, but no effective fishery monitoring or management is in place. Sports fishers voluntarily release bill fish during tournaments to help conserve the species. The taking of turtles is prohibited by law. Enforcement of fisheries laws by the Coastguard is effective. Curaçao actively contributed to a joint EEZ management plan funded and endorsed by the former Ministry of Economic Affairs ${ }^{161}$. A MoA was signed with the American Waitt Institute, which carries out the Blue Halo Initiative, a collaborative initiative between the Waitt Institute and small island government partners, such as Curaçao, to develop and implement comprehensive and sustainable ocean policies. One of the outcomes of this initiative is a marine and coastal management plan (2015), which still has to be implemented. The Ley Marco, the law for the protection of the marine environment, was adopted but has not yet been implemented in local regulations.

\section{Sint Maarten}

Sint Maarten has instituted an MPA and has declared a shark fishing moratorium to protect this keystone species. Enforcement of the Marine Park Ordinance and Marine Park protection is being actively pursued by the Coastguard and the Nature Foundation. Sint Maarten has had minimal participation in the joint EEZ management plan funded by the former Ministry of Economic Affairs.

\section{Target 7 \\ Sustainable agriculture, aquaculture and forestry}

By 2020, areas under agriculture, aquaculture and forestry are managed sustainably, ensuring conservation of biodiversity

\section{Why is this target important?}

The demands for food, fibre and fuel are increasing and the pressures they put on our ecosystems and biodiversity are rising. To help ease those pressures the key sectors of agriculture, aquaculture and forestry need to adopt practices that minimise negative impacts, making their activities more sustainable over the long term. There is a need to decouple production from environmental impacts, including through the use of innovation and scientific and technical advances. This target challenges governments and businesses to define sustainable practices and to adopt them as widely as possible ${ }^{162}$.

\section{Summary of progress towards the target}

The forestry and aquaculture sectors have made considerable progress so far towards Aichi Targets 7 (see also National Target 3, section IV-3). However, the dominant position of agriculture in the Dutch landscape and the associated negative impacts on biodiversity make it clear that considerable efforts are still needed. Progress towards Aichi Targets 7 in the Caribbean Netherlands, Aruba, Curaçao and Sint Maarten is assessed as 'moving away from target'.

\section{Dutch contribution to the achievement of Aichi Targets 7}

\section{Agriculture}

The agricultural sector is moving towards sustainable production and consumption, but progress is slow, despite the implementation of positive and substantial actions like the greening of the common agricultural policy and agri-environment schemes. A surplus of nutrients such as nitrogen and phosphate can lead to pollution of soil, water and air (Figure 14, section IV-3). Due to policy measures and efforts within agriculture, the nutrient surplus in

162 Global Biodiversity Outlook A mid-term assessment of progress towards the implementation of the Strategic Plan for Biodiversity 2011-2020 
Dutch soils has declined. However, this surplus rose again in 2015, possibly due to an increase in livestock numbers after the abolition of the milk quota.

The population of birds on farmland is still decreasing and considerable efforts are being made to find a new system to improve farmland biodiversity (Figure 7, section III-3). Improvements have been made. The proportion of livestock housing that meets sustainability criteria (Aichi Targets 3) increased to approx. 14\%, the use of raw materials with a sustainability label is increasing

(Aichi Targets 4), as is the organic production percentage (currently still small at $3.1 \%$ of the total agricultural area (Aichi Targets 4 ) and consumption of organic produce. Information on relevant national initiatives and activities to promote the conservation and sustainable use of pollinators can be found at national target 2 (section IV-2).

\section{Forestry}

All forests in the Netherlands are legally protected and many of them are sustainably managed. About $46 \%$ of the forest area has an FSC label (167,000 ha), and a minor area $(3,000 \mathrm{ha})$ carries the PEFC label ${ }^{163}$. The forests are ageing and the amounts of dead wood and growing stock are increasing, which generally results in higher biodiversity values, including forest birds (see section IV-3).

\section{Aquaculture}

The Dutch aquaculture sector is small but diverse, including shellfish such as mussels and oysters, fish such as eel and catfish, and recently also seaweed cultivation. Blue shell mussel (Mytilus edulis) culture is the main representative of the aquaculture sector. Mussel seed are fished in the Wadden Sea off the north coast and relayed in bottom cultivation parcels in the Oosterschelde in the southwest delta. The Wadden Sea and Oosterschelde are protected Natura 2000 sites. Over the years, the mussel seed returns from natural banks have declined and mussel seed dredging in the Wadden Sea is considered unsustainable and therefore unacceptable. The nature conservation NGOs, the mussel fishery and the responsible government department have agreed to a transition phase for the sector. The limited availability of mussel seed makes it impossible to achieve the maximum production and sales. The sector is experimenting with alternative methods for seed capture (using mussel seed traps) to maintain the supply of mussel seed and fish sustainably. These alternative methods are still in the research, test and innovation phases ${ }^{164}$.

For the fish farming sector, European eel and catfish (African catfish and claresse) are the most important species. (Nationaal Strategisch Plan Aquacultuur 20142020) ${ }^{165}$. However, the production volumes of these species have declined in recent years due to poor economic results. Fish breeding is carried out by just a few dozen companies. Most fish farming companies work indoors and use environmentally friendly closed recirculation systems (RAS). However, eels cannot reproduce in captivity and young glass eels must be caught in natural waters. The number of glass eels has dramatically declined (Figure 33) and the low availability of glass eel is a major threat to eel farming. The Dutch association of eel traders, fish farmers and the organisation of professional fishers is also working on sustainable solutions for catching and farming eels and for environmental and animal-friendly processing, and is stimulating scientific research on eels ${ }^{166}$.

\section{Caribbean contribution to the achievement of Aichi Targets 7}

Forestry and aquaculture are not an issue in the Caribbean Netherlands. A fish farm built on Bonaire in 2009 never became operative. The islands have potential for horticulture and various projects are underway to develop this sector sustainably. Recently, Wageningen University and the Council of International Education and Exchange launched an initiative to develop an algae park on Bonaire to produce algae as an alternative to soy or fishmeal within the next five years. The only substantial agricultural sector on all the islands is livestock farming. Thousands of goats, cows, donkeys and pigs roam freely on the islands, which is a major threat to the fragile terrestrial and marine ecosystems. Efforts to make livestock breeding more sustainable are still small-scale.

\section{Aruba}

There is no serious aquaculture or forestry sector on Aruba. Agriculture consists mainly of livestock grazing, which can be considered unsustainable as most of the animals roam freely on the island.

164 https://www.wur.nl/nl/artikel/Mosselzaad-invanginstallaties-MZIs.htm 165 https://www.parlementairemonitor.nl/9353000/1/j9vvij5epmj1ey0/ vjsgnjes1vsj

166 https://www.clo.nl/indicatoren/nl1227-achteruitgang-paling; https://www. wur.nl/nl/Dossiers/dossier/Paling-Aal.htm 
Glass Eel numbers entering the IJsselmeer

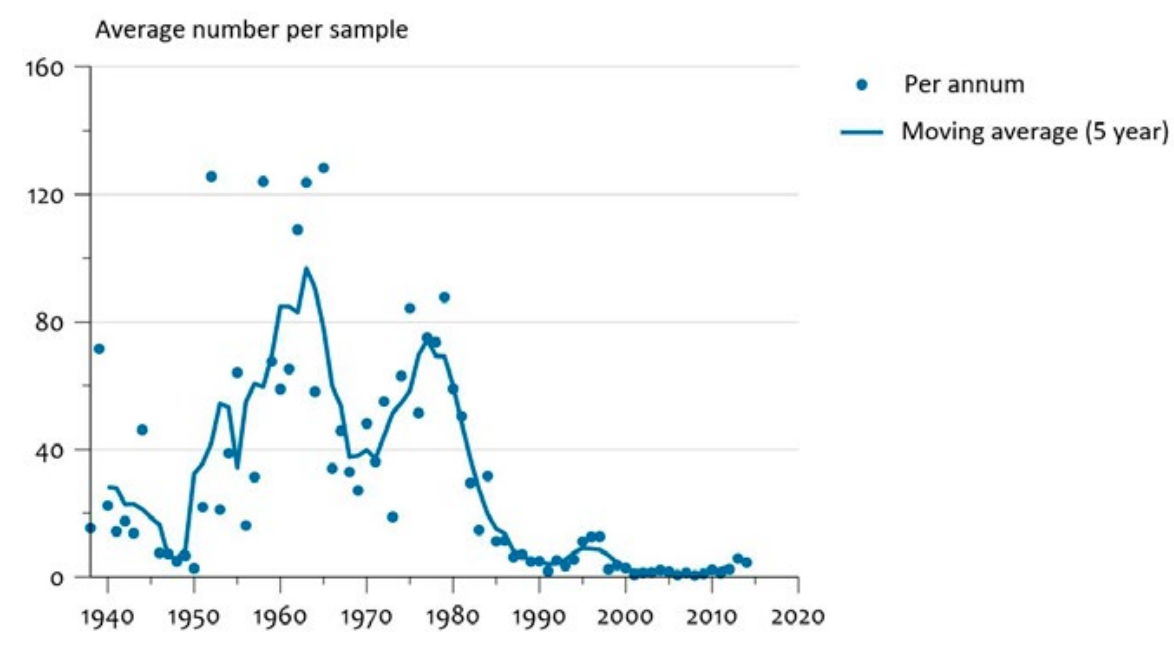

Bron: Imares.

Figure 33. Trend in glass eel numbers entering the IJsselmeer

\section{Curaçao}

There is no serious aquaculture or forestry sector on Curaçao. Agriculture consists mainly of livestock grazing, which can be considered unsustainable as most of the animals roam freely on the island. There is some smallscale agriculture and horticulture, which the government is endeavouring to support.

\section{Sint Maarten}

There is small-scale but not insignificant farming by private individuals for personal consumption and resale to the public. These initiatives are not supported by the government. Unsustainable free-roaming livestock grazing and the impacts of invasive species such as monkeys, raccoons and iguanas also occur. There is no aquaculture on Sint Maarten. 


\section{Target 8 \\ Pollution reduced}

By 2020, pollution, including from excess nutrients, has been brought to levels that are not detrimental to ecosystem functions and biodiversity.

\section{Why is this target important?}

Pollution, in particular the accumulation of reactive nitrogen and phosphorus nutrients in the environment, is among the most significant causes of biodiversity loss and of damage to the ecosystems on which we depend. Wetland, coastal, marine and dryland areas are especially vulnerable through a range of impacts, including the creation of marine 'dead zones' as algae build up, die and decompose and in the process deprive large areas of oxygen. The target encourages decision makers to take the necessary actions to minimise the release of these and other pollutants ${ }^{167}$.

\section{Summary of progress towards the target}

Aichi Targets 8 has not been achieved yet. Although pollution has been significantly reduced since 1990 in the Netherlands, several target levels have still not been met, especially for nitrogen. Progress towards Aichi Targets 8 in the Caribbean Netherlands is assessed as 'on track to achieve target'. Progress in Aruba, Curaçao and Sint Maarten is assessed as 'progress towards target but at an insufficient rate'.

\section{Dutch contribution to the achievement of Aichi Targets 8}

\section{Nitrogen pollution}

Nitrogen components can lead to eutrophication of ecosystems. When this pollution exceeds certain levels (the critical load) it is damaging to biodiversity. Agriculture and transport are the main sources of nitrogen pollution. The Dutch government and the provincial governments are implementing the Programmatic Approach to Nitrogen (PAN, main measure 4, section III-4) to reduce nitrogen pollution, which is mainly caused by agriculture.

167 Global Biodiversity Outlook A mid-term assessment of progress towards the implementation of the Strategic Plan for Biodiversity 2011-2020
Every four years EU Member States are obliged to renew their action programme under the Nitrates Directive $(91 / 676 / E E G)^{168}$. The Nitrates Directive aims to prevent or reduce water pollution caused by nitrates from agricultural sources. The renewed (fifth) Dutch action programme became effective in early 2014. This programme aims to establish average equilibrium phosphate fertilisation at no more than an average target value of $50 \mathrm{mg} / \mathrm{l}$ in groundwater across the country. The programme will therefore also contribute towards achieving the Water Framework Directive goals. Nevertheless, additional efforts will be needed to achieve these goals.

Environmental conditions in the Netherlands have improved substantially since the 1990 s. Acidifying deposition has decreased by $49 \%$ since 1990 (mainly due to a reduction in emissions of sulfur dioxide) ${ }^{169}$ and eutrophication of surface waters has also decreased substantially. Nevertheless, target values have still not been reached and the water quality of most waterbodies does not meet the requirements under the EU Water Framework Directive (see Figure 34). Efforts to meet these objectives are ongoing.

Nitrogen emissions and deposition have decreased since 1990 , but in recent years at an insufficient rate. Moreover, nitrogen deposition has not decreased since 2010 (see Figure 8, section III-4). Critical load exceedance is still significant across large areas. Other pollution, such as from oil spills, plastics and crop protection chemicals also cause significant damage to biodiversity.

\section{Chemical pollution}

The impacts of pesticides on nature, especially on bees, is particularly topical at the moment. The Natural Capital Agenda (NCA) sets out some concrete actions that could be taken. The environmental burden of chemical crop protection is barely decreasing and is still very high (Figure 35). The Dutch government stimulates farmers to create arable field margins with wild flowers specially designed to facilitate functional agro-biodiversity and stimulates the use of non-chemical methods. Farmers are required to use emission reducing techniques. The Dutch government and relevant stakeholders have developed a national bee strategy to reduce the impact on bees.

$168 \mathrm{http}: / /$ ec.europa.eu/environment/water/water-nitrates/index_en.html 169 https://www.clo.nl/indicatoren/nl0184-verzurende-depositie; https://www. clo.nl/indicatoren/

nl0183-verzuring-en-grootschalige-luchtverontreiniging-emissies 
Physical chemical quality of surface waters in the Netherlands

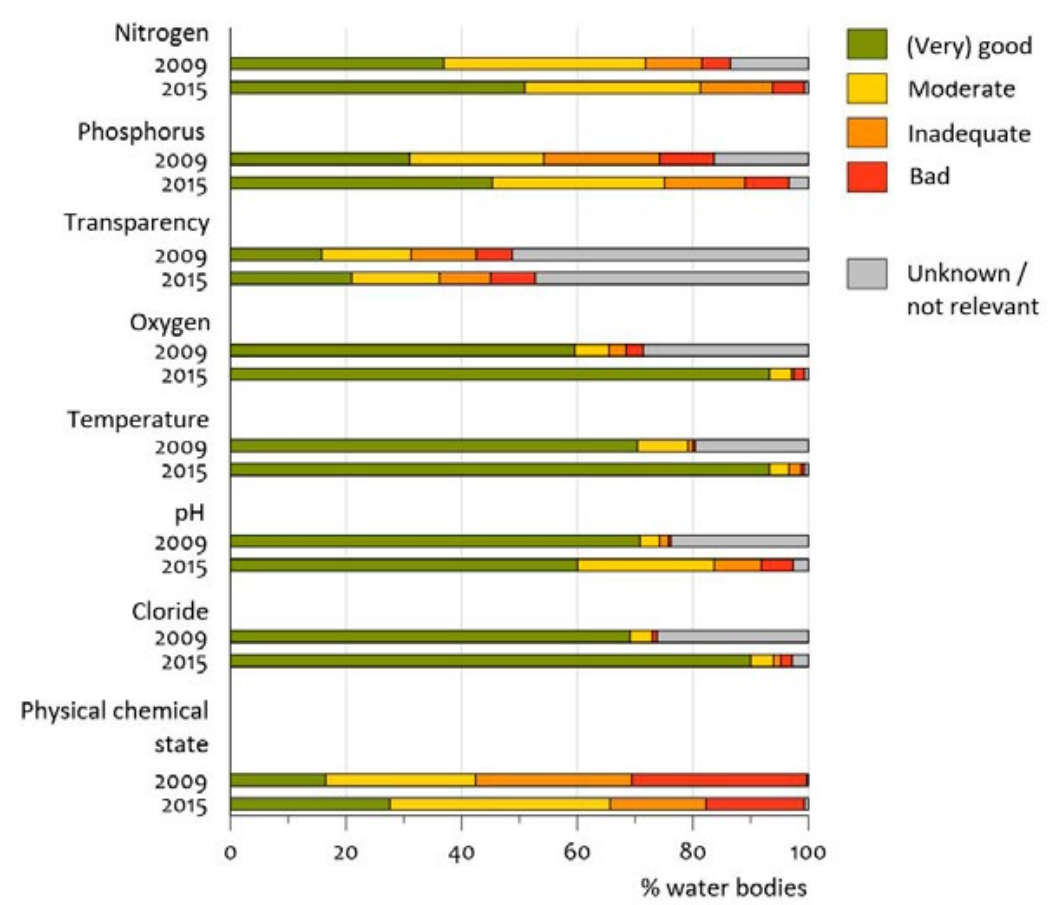

गn: IHW (Waterschappen, RWS); bewerking PBL.

$\mathrm{PBL} /$ nov15

www.clo.nl/nlo25215

Figure 34. Quality of surface water according to the categories under the Water Framework Directive

\section{Sales of chemical crop protection products}

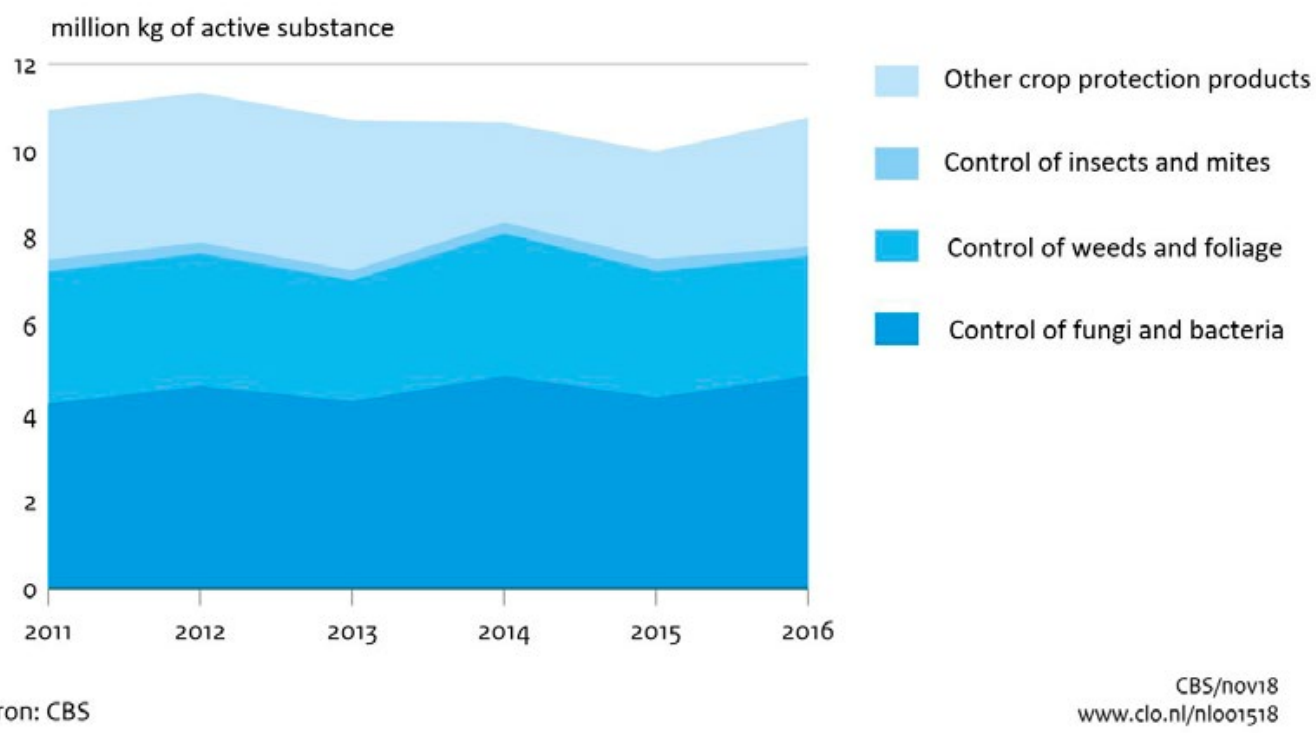

Figure 35. Sales of chemical crop protection products per substance type 


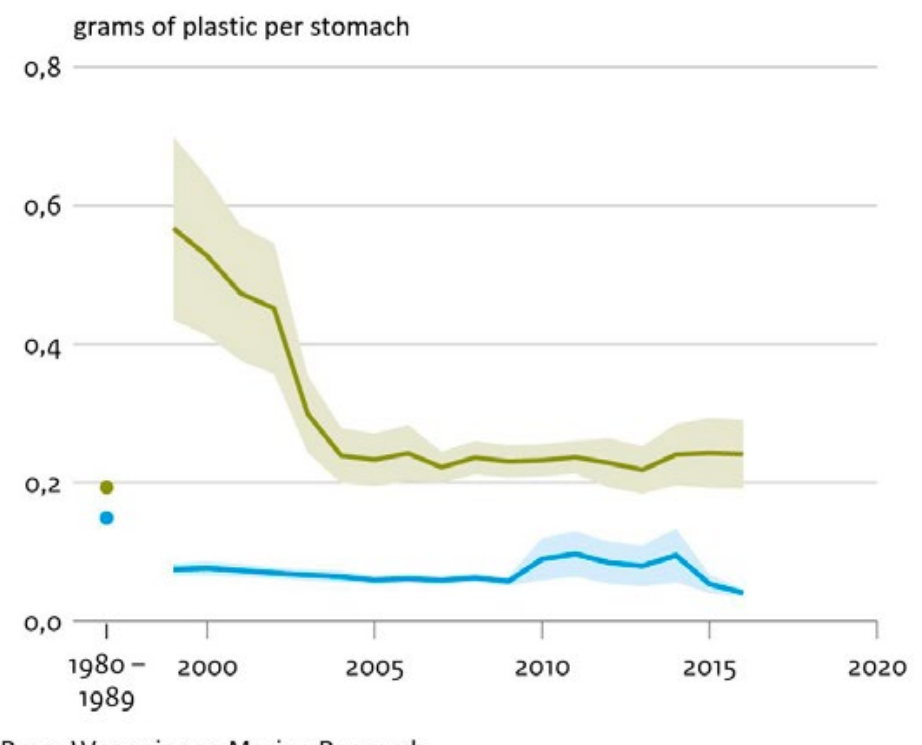

Bron: Wageningen Marine Research

Figure 36. Plastic in stomachs of northern fulmar

Plastic waste and oil spills

A range of actions will be taken to control and reduce marine litter, in cooperation with parties such as the EU Environment Council, IMO and UNEP (NCA). Furthermore, the Dutch government has permitted The Ocean Cleanup, a non-profit organisation developing technologies to remove plastic waste from the oceans, to conduct its North Sea Prototype test off the Dutch coast. The environmental burden of plastics in bird stomachs is decreasing, but in recent years at an insufficient rate (Figure 36 ). Numbers of sea bird oil casualties have decreased significantly (Figure 37).

\section{Caribbean contribution to the achievement of Aichi Targets 8}

A state-of-the-art sewage treatment plant on Bonaire is leading to cleaner seawater and provides protection for the reefs. In March 2013, Selibon N.V., the national solid waste processing plant, opened a waste collection point on Bonaire where the public can bring waste for recycling. Selibon also regularly checks the coastline for rubbish and organises clean-ups with volunteers. Dive Friends Bonaire runs a Debris Free Bonaire programme of eco-friendly activities and collection of debris washed ashore for separation at the dive shop. Dive Friends Bonaire also organises quarterly ocean clean-up dives, which are well

\author{
Consumption plastic \\ - Average of period \\ 1980 - 1989 \\ - Average of previous \\ 5 year period \\ Uncertainty

\section{Industrial plastic} \\ - Average of period \\ 1980 - 1989 \\ - Average of previous \\ 5 year period \\ Uncertainty \\ WUR/nov17 \\ www.clo.nl/nln10509
}

attended by volunteers. The first Dive Friends Bonaire quarterly clean-up dive, organised in partnership with Stinapa and STCB, was held on Saturday 27 January 2018. The turnout was outstanding, with 116 volunteers participating. In addition, an OSPAR beach litter monitoring project was set up in a citizen science project in August 2018. Bonaire is working towards a ban on solar screen products containing oxybenzones harmful to corals, in combination with a communication and outreach plan to minimise the use of such products. The Saba recycling plant was opened in 2015 and in May 2018 the Saba Commissioner of Infrastructure and Waste Management signed a letter of intent for the purchase of a new, state-of-the-art waste processing installation for the island. In April 2018 the Sint Eustatius island government agreed a five year contract with a local waste management company. The intention is to move away from open field landfills to a more innovative environmentally friendly waste management system.

\section{Aruba}

Hotel wastewater has been treated at the Bubali lake for the last 40 years. Three sewage treatment plants are in operation. Residential wastewater has also been treated since 2007 . Between $35 \%$ and $40 \%$ of cardboard, aluminium and ferro metals are recycled. The government has a 
Oil pollution and seabirds

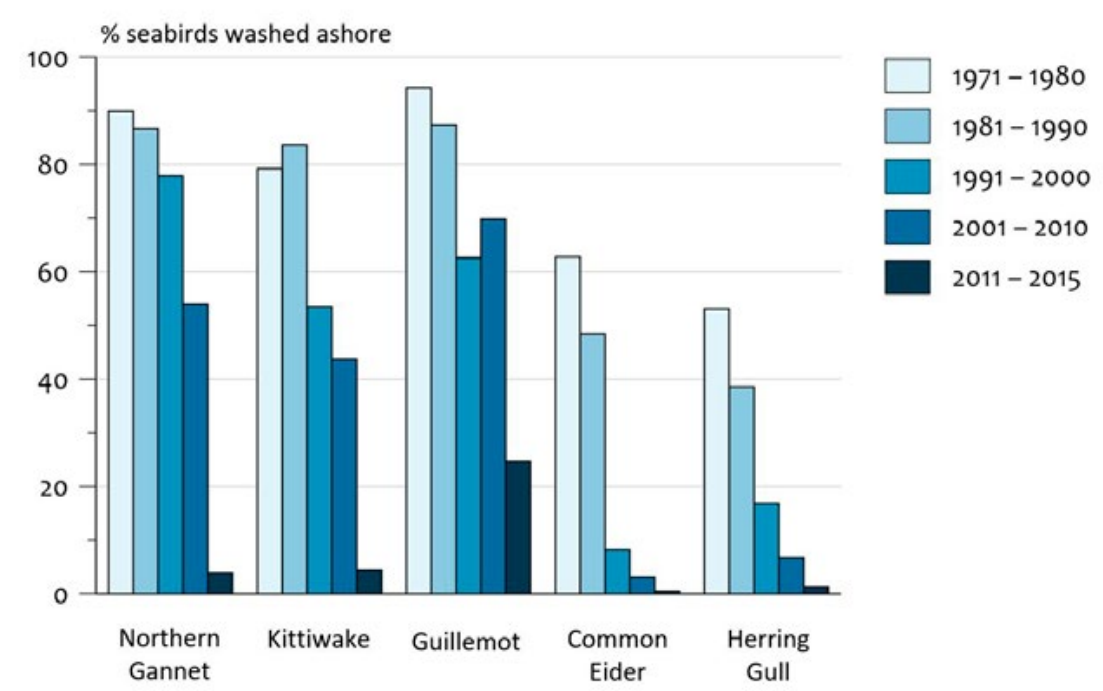

Bron: Nederlandse Zeevogelgroep.

WUR/mrt16 www.clo.nl/nl125404

Figure 37. Percentages of seabirds washed ashore due to oil pollution

short-term strategy to address the solid waste challenges of the island by redirecting the municipal waste to a private recycling company. Furthermore, the government of Aruba is working on a long-term solution in which all municipal waste will be incinerated with energy recovery for the generation of electricity.

\section{Curaçao}

There are and have been several initiatives to recycle and reduce pollution. Several volunteer groups organise regular clean-ups and publicise cases of illegal dumping.

\section{Sint Maarten}

Poor waste management causes major problems, including frequent toxic landfill fires, and the island has no waste separation and no recycling. The ineffective disposal of waste is a public health concern and is a source of air pollution and water and soil contamination. On

31 May 2018 the government of Sint Maarten organised a forum with various stakeholders to inform and discuss the waste situation on the island. There is a consensus that now is the right moment to solve the waste issue in a sustainable way. The forum was organised to share ideas and approaches with all stakeholders so that all parties can work together on sustainable short- and long-term solutions. Follow-up fora are planned for the near future.
There are also initiatives by NGOs. For example, the Nature Foundation's 'Reduce \& Reuse Sint Maarten' project teaches and encourages residents, children and establishments to reduce their waste output and clean up the environment, and EPIC is designing a project for compost recycling. 


\section{Target 9 \\ Invasive alien species prevented and controlled}

By 2020 , invasive alien species and pathways are identified and prioritised, priority species are controlled or eradicated and measures are in place to manage pathways to prevent their introduction and establishment.

\section{Why is this target important?}

The movement of animals, plants and other organisms around the planet represents one of the greatest threats to biodiversity. Species introduced into new environments, whether deliberately or accidentally, have contributed to more than half of the animal extinctions for which the cause is known. Species invasions also carry enormous economic costs. Under this target, governments aim to reduce these costs to society and to biodiversity through the prevention, control and eradication of invasive alien species $^{170}$.

\section{Summary of progress towards the target}

Aichi Targets 9 has not yet been achieved. Many actions have been taken, species and pathways have been identified and prioritised, but the number of potentially invasive alien species is still increasing. Aquatic species in particular are a major management challenge. Progress towards Aichi Targets 9 in the Caribbean Netherlands, Aruba, Curaçao and Sint Marten is assessed as 'progress towards target but at an insufficient rate'.

\section{Dutch contribution to the achievement of Aichi Targets 9}

Recognising the increasingly serious problem of invasive alien species in Europe, the European Commission published the Regulation on Invasive Alien Species (IAS) in September 2013. The IAS Regulation is a dedicated legislative instrument for tackling the problem in a coordinated, joint effort across all Member States (see also section IV-5). The invasive alien species and pathways have been identified and measures taken, but the number of alien species in the Netherlands and Europe is still increasing (see also National Target 5, section IV-5).

170 Global Biodiversity Outlook A mid-term assessment of progress towards the implementation of the Strategic Plan for Biodiversity 2011-2020

\section{Caribbean contribution to the achievement of Aichi Targets 9}

Invasive alien species are considered a major threat to the terrestrial and marine environment of all three islands in the Caribbean Netherlands. An inventory has been made and there is an urgent need for an invasive alien species strategy and action plan containing prevention, intervention, control and mitigation measures. A draft strategy has been drafted, but no action has yet been taken on any of the islands. Ongoing programmes to control the invasive lionfish (Pterois volitans) run by the marine protected areas are proving to be effective in reducing and controlling numbers to depths that can be reached while scuba diving, which includes most of the coral reefs. A pilot project to test methods to use fish traps for lionfish, funded by WWF-NL is ongoing. The results will be passed on to fishers enabling them to pursue this as a new resource and target lionfish in deep waters where they have been unreachable so far. The effects of the invasive sea grass Halophila stipulacea are being studied in Sint Eustatius and Bonaire.

\section{Aruba}

Invasive species are a major problem on Aruba and inventories have been carried out ${ }^{171}$. Aruba is actively contributing to development of an invasive alien species strategy. The Lion Fish Foundation conducts lionfish control and the Arikok National Park does its best to control the invasive boa constrictor (snake) population.

\section{Curaçao}

Invasive species are a major problem on Curaçao. An inventory is available (see Aruba). Curaçao is presently actively contributing to the development of an invasive alien species strategy. The dive operators are actively controlling lionfish numbers. However, widespread lionfish populations between 30 and 150 m deep could be responsible for maintaining high densities of lionfish recruits, despite local shallow-biased control programmes. This highlights the need for management plans that include

171 Burg, W. J., van der, J. de Freitas, A. O. Debrot and L. A. P. Lotz. 2012. Naturalised and invasive alien plant species in the Caribbean Netherlands: status, distribution, threats, priorities and recommendations. PRI report 437 . Imares report C185/11;

Buurt, G. van and A.O. Debrot, 2011. Exotic and invasive terrestrial and freshwater animal species in the Dutch Caribbean. IMARES report C001/12; Buurt, G. van and A.O. Debrot, 2012. Introduced agricultural pests, plant and animals diseases and vectors in the Dutch Caribbean, with an "Alert species" list. IMARES Report number C193/11; Debrot, A.O, G. van Buurt and M. J. A. Vermeij. 2011. Preliminary overview of exotic and invasive marine species in the Dutch Caribbean. IMARES rept. C188/11. 
lionfish populations below the depth limit of recreational diving in order to address all aspects of the local population and maximise the effectiveness of control efforts. The Carmabi Foundation has been running a goat control programme in the Christoffel Park and the Curaçao government has eradicated a rapidly expanding cat population on Klein Curaçao to protect the nesting terns. Both initiatives have no sources of funding and rely on a few active people and hence are very vulnerable to discontinuity.

\section{Sint Maarten}

Invasive species are a major problem on Sint Maarten. A recent inventory is available (see Aruba). Sint Maarten is also actively contributing to the development of an invasive species strategy. The Nature Foundation runs a programme to control lionfish (Bervoets, 2010a) and has a Lionfish Response Plan (2010).

\section{Target 10 \\ Ecosystems vulnerable to climate change}

By 2015 the multiple anthropogenic pressures on coral reefs and other vulnerable ecosystems impacted by climate change or ocean acidification are minimised so as to maintain their integrity and functioning.

\section{Why is this target important?}

Climate change and ocean acidification (caused by increased atmospheric carbon dioxide concentrations) are becoming increasingly serious threats to the ecosystems and the services they provide. Some habitats, including coral reefs, mountains and rivers, are especially vulnerable to one or both of these pressures. While mitigating climate change is clearly the key long-term priority, urgent measures to relieve other pressures can make these ecosystems more resilient, protecting their biodiversity and the livelihoods of millions of people who depend on them. The urgency of this action was reflected in the decision to make 2015 the deadline for meeting this target, instead of 2020 as with most of the other targets $^{172}$.

\section{Summary of progress towards the target}

All in all, reasonable progress has been made towards achieving Aichi Targets 10, but continuation of policies and activities will be needed to improve the biological values of vulnerable systems, such as the Wadden Sea, and to face the impacts of climate change on this and other vulnerable ecosystems. Progress towards Aichi Targets 10 in the Caribbean Netherlands, Aruba, Curaçao and Sint Maarten is assessed as 'progress towards target but at an insufficient rate'.

\section{Dutch contribution to the achievement of Aichi Targets 10}

Nederland literally means 'low country', which illustrates that the Netherlands, including its natural areas, are especially vulnerable to the impacts of climate change. Dealing with sea level rise, shifts and changes in the discharges of river systems, subsidence, drought, salinisation and guaranteeing adequate freshwater supply is a

172 Global Biodiversity Outlook A mid-term assessment of progress towards the implementation of the Strategic Plan for Biodiversity 2011-2020 


\section{Egg-laying Dates of Warblers}

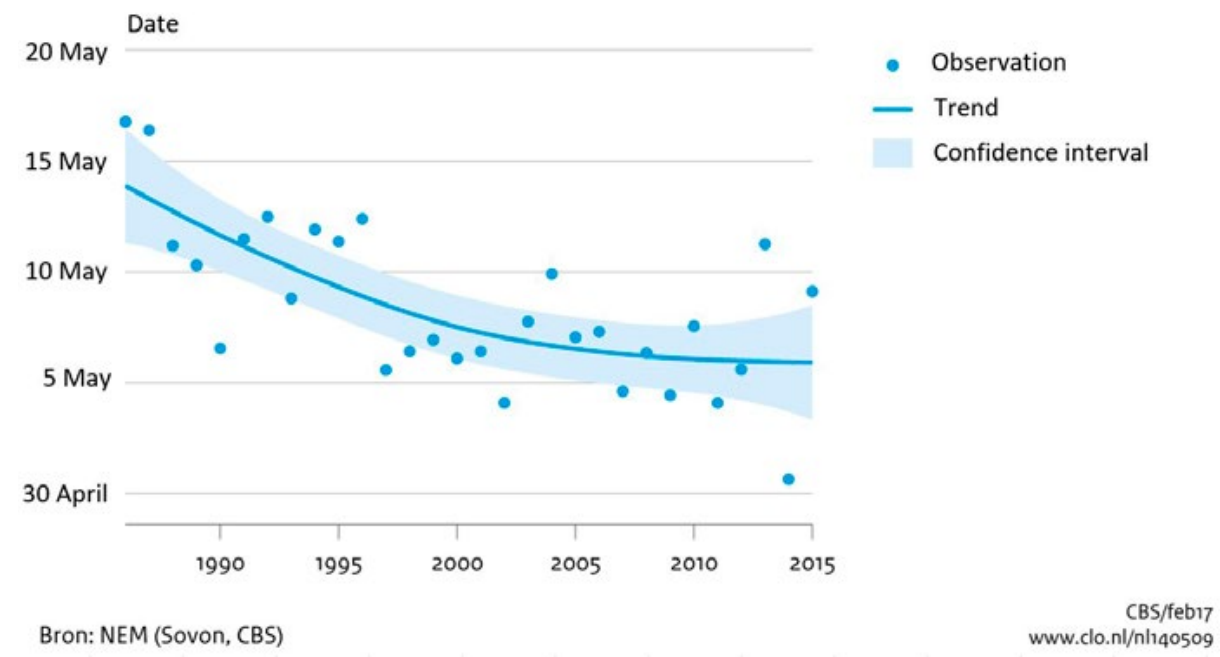

Figure 38. Since the 1980 s the trend in egg-laying dates of warblers has been towards earlier in the year

Community Temperature Index Dutch Flora

Bron: Sparrius, 2018. Floron

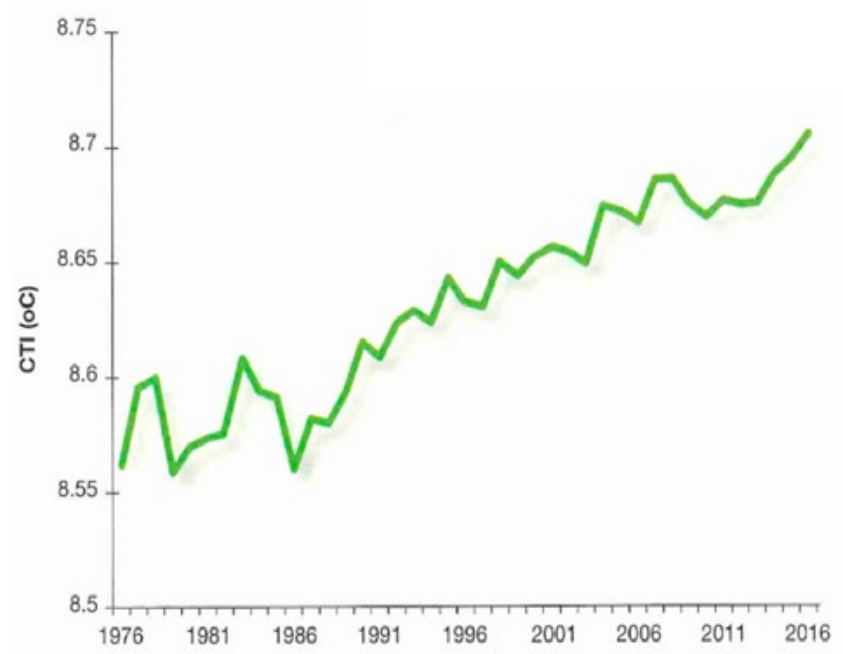

Figure 39. Since the 1980s the temperature index of Dutch flora has increased

matter of national survival. The Dutch are well-known for their 'fight against the water' but increasingly they recognise that they have to 'build with nature' to be able to combat the impacts of climate change. Building with Nature is a design approach that takes the ecosystem as a starting point and makes use of natural processes for the sustainable management of coastal, delta and riverine regions. A consortium has been formed in which government, knowledge institutions, NGOs and private enterpris- es are building a network of expertise to pool and expand knowledge on how the concept of Building with Nature can be developed and implemented in projects ${ }^{173}$. The government's white paper 'Nature Ambition for the Large

173 Vriend, H.J. de, and Van Koningsveld, M., 2012. Building with Nature: Thinking, acting and interacting differently. EcoShape, Building with Nature, Dordrecht, the Netherlands. 


\section{Components conservation status}

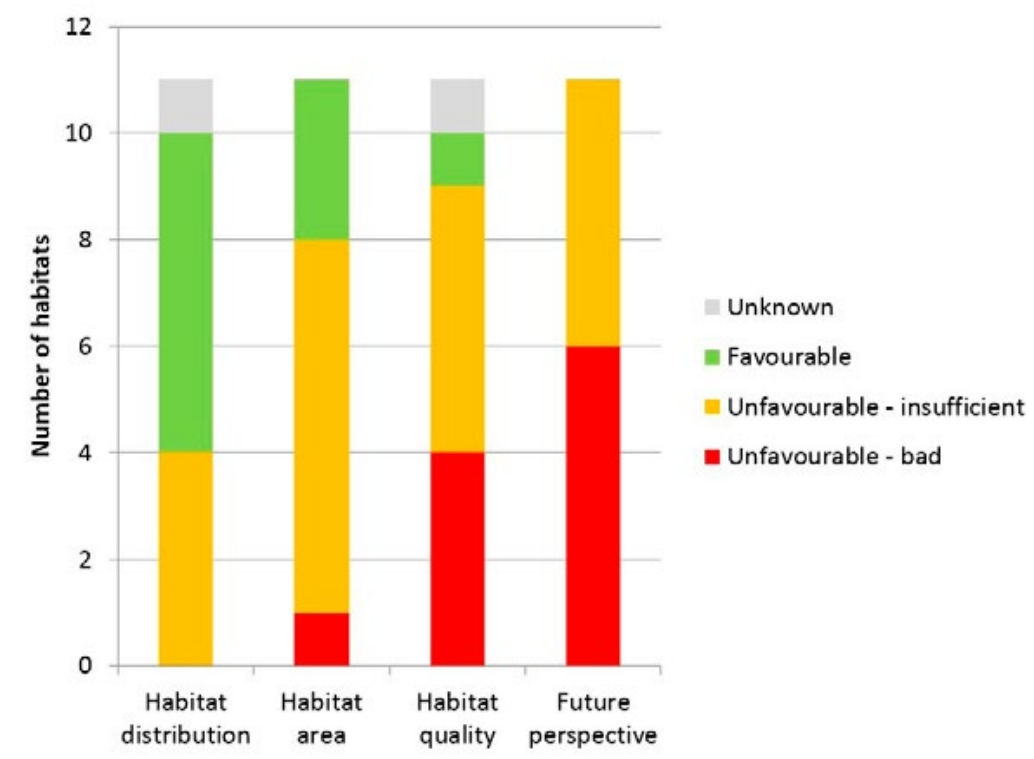

Figure 40. Assessment in 2017 of the 11 marine and terrestrial habitats in the Caribbean Netherlands for habitat distribution, habitat area, habitat quality and future perspective

to a sustainable harvesting method by 2020. At the same time, an ecosystem rehabilitation programme, 'Towards a healthy Wadden Sea Ecosystem for nature and man' (Naar een rijke Waddenzee $\left.{ }^{176}\right)$, was launched with financial aid from the legally constituted Wadden Fund.

\section{Caribbean contribution to the achievement of Aichi Targets 10}

The state of nature in the Caribbean Netherlands was assessed in $2017^{177}$. The 11 marine and terrestrial habitats were assessed for the following indicators: habitat distribution, habitat area, habitat quality and future perspective (Figure 40). It revealed that the score was unfavourable (insufficient or bad) in most cases, especially for habitat quality and future perspective. This is due to many threats, but especially overfishing, free-roaming grazing livestock, invasive species and pollution. The actions taken to reduce these threats are basically insufficient, which means that these habitats are probably not resilient enough to withstand climate change. As such, the future perspective of all habitats was assessed (in 2017) as unfavourable-insufficient and unfavourable-bad.
There is no structural monitoring of the impact or effects of climate change. Sea level rise and higher temperatures will engender their own effects or amplify the effects of other pressures. Unusually warm ocean temperatures during the late summer and fall of 2010 caused coral bleaching, which persisted long enough to kill about $10 \%$ to $20 \%$ of the corals within six months. The hurricane season of 2017 was extremely active and destructive on the windward islands (hurricanes Irma and Maria, in particular). They not only had a major impact on Sint Maarten, but also on Saba and Sint Eustatius.

Since the end of 2010, several measures have been taken (or are being prepared) to decrease the anthropogenic pressures on the coral reefs of the Caribbean Netherlands. These include:

- construction of the first sewage treatment plant on Bonaire to decrease the impact of waste water on coral reefs;

- measures to reduce the impacts of overgrazing of land, erosion of soil and sediment deposition on coral reef ecosystems for all islands;

- implementation of the Guidelines of the International Convention for the Prevention of Pollution from Ships (MARPOL); 
- implementation of an integral management plan for fisheries and marine biodiversity in the EEZ;

- several protection measures for the Saba Bank: The area was officially declared the Saba Bank National Park on 12 December 2010 and a management plan was implemented. The Bank was declared a marine protected area by the Dutch government on 21 December 2010 and in October 2012 it was declared a Particularly Sensitive Sea Area (PSSA) by the Marine Environment Protection Committee of the International Maritime Organization (IMO). These designations prohibit anchoring by tankers and other large ships on the entire Bank, both in territorial waters and in the EEZ, while the PSSA status is important as a legal basis by which to regulate international shipping and its associated risks, over and around the Bank. As of June 2013, the Saba Bank is covered by two 'associated protective measures' to control the maritime activities in that area. A no-anchoring zone for all ships has been established to prevent the large 'scars' on the bottom, threatening coral reefs and other unique sea life. Additionally, an Area To Be Avoided (ATBA) for ships of 300 gross tonnage or more came into force, as ships passing over the Bank often destroy lobster and fish trap marker buoys, leaving the lost traps to continue fishing as 'ghost traps'.

Many actions are underway to further minimise the anthropogenic pressures on the coral reefs of the Caribbean Netherlands. However, these actions cannot compensate for impacts on a global scale, such as climate change.

\section{Aruba}

All terrestrial and coastal ecosystems are vulnerable to climate change, especially the fringing coral reefs and the nesting beaches for sea turtles. The multiple anthropogenic pressures from tourism, livestock grazing, fisheries, coastal development, etc. remain high, which limits the ecosystems' resilience to climate change. The DNM (Directie Natuur en Milieu) monitors the acidity of the coastal zone and on two locations a two kilometre transect is monitored into the open sea. For the MPAs climate change adaptation strategies will be prepared to maintain the coral reefs, seagrass fields and mangrove areas.

\section{Curaçao}

All terrestrial and coastal ecosystems are vulnerable to climate change, especially the fringing coral reefs and the nesting beaches for sea turtles. Despite the 1997 zoning plan, the multiple anthropogenic pressures from tourism, livestock grazing, fisheries, coastal development, etc. remain high, which limits the ecosystems' resilience to climate change.

\section{Sint Maarten}

All terrestrial and coastal ecosystems are vulnerable to climate change, especially the coral reefs and the nesting beaches for sea turtles. The multiple anthropogenic pressures from tourism, coastal development, etc. remain high, which limits the ecosystems' resilience to climate change. The effects of climate change are especially visible in the increasing number of major hurricanes, such as Hurricane Gonzalo (2014) and Hurricane Irma (2017). The latter even passed right over Sint Maarten, damaging the coral reefs and ecosystems. The Nature Foundation developed a response plan for the effects of climate change on the marine and coastal zones of Sint Maarten, which shows that key and critical infrastructure, including the country's airport, port, police headquarters and hospital, can all be expected to be impacted by the effects of climate change. A report was produced on the increasing occurrence of sargassum seaweed Halophila stipulacea in $2013^{178}$.

\section{Dutch contribution to the achievement of Aichi Targets 10 at a global level}

The PEARL project (Preparing for Extreme and Rare events in coastal regions) which has begun in Sint Maarten seeks to understand processes that increase the risk of flooding on the Dutch side of the island. Hydrodynamic modelling will make it possible to investigate surge impacts related to the development of infrastructure, future land development scenarios and climate conditions (storms, hurricanes). The aim is to develop adaptive, sociotechnical risk management measures and strategies for coastal communities to combat extreme hydro-meteorological events.
178 https://researchportal.port.ac.uk/
portal/files/559673/S1755267213000961a.pdf 


\section{Strategic Goal C}

To improve the status of biodiversity by safeguarding ecosystems, species and genetic diversity

\section{Target 11 \\ Protected areas}

\begin{abstract}
By 2020, at least 17 per cent of terrestrial and inland water areas and 10 per cent of coastal and marine areas, especially areas of particular importance for biodiversity and ecosystem services, are conserved through effectively and equitably managed, ecologically representative and well-connected systems of protected areas and other effective area-based conservation measures, and integrated into the wider landscapes and seascapes.
\end{abstract}

\section{Why is this target important?}

As human activities come to dominate larger and larger areas of the planet's land and water surface, governments have recognised the need to enlarge the network of protected areas and other effective area-based conservation measures as a means to reconcile development with the conservation of biodiversity. This target represents a modest increase in the proportion of land protected and a more ambitious increase for marine protected areas, which begin from a much lower level. The target also recognises that biodiversity will not be safeguarded simply by establishing more protected areas. They need to represent the diversity of the planet's ecological regions and include the most critical sites for threatened species; they need to be connected, to be effectively managed and to command the support of local populations ${ }^{179}$.

\section{Summary of progress towards the target}

Although the protected areas in the Netherlands amount to well over $17 \%$ of the terrestrial and inland water area and $10 \%$ of coastal and marine areas, Aichi Targets 11 has not yet been achieved in full. Management of these areas is well organised, but environmental conditions have

179 Global Biodiversity Outlook A mid-term assessment of progress towards the implementation of the Strategic Plan for Biodiversity 2011-2020 a large negative impact on the improvement of the protected areas. Progress towards Aichi Targets 11 in the Caribbean Netherlands, Aruba, Curaçao and Sint Maarten is assessed as 'progress towards target but at an insufficient rate'.

\section{Dutch contribution to the achievement of Aichi Targets 11}

Establishment of protected areas is a direct response to concerns over biodiversity loss, and so protected area coverage is a valuable indicator of commitment to conserving biodiversity and reducing loss at a range of levels. The protected areas in the Netherland are the Natura 2000 sites and the NEN (main measure 1, Figure 1, section II-1). The total area of Natura 2000 sites in the Netherlands currently amounts to 20,606 square kilometres. This is more than $14 \%$ of the terrestrial and inland water area, and more than $23 \%$ of coastal and marine areas (North Sea, Wadden Sea, Oosterschelde and Westerschelde). The Natura 2000 sites are designated and protected by law and are part of the NEN. The NEN is a nationally designated area protected by a 'no-unless' planning regime and where conservation measures apply. The protected area within the NEN is also being expanded by habitat creation (see section III-1). The area of Natura 2000 sites and the terrestrial NEN together cover more than $26 \%$ of the terrestrial and inland water area. Despite these figures, the intended NEN area is expected not to be large enough to accommodate viable populations of all 'Dutch' terrestrial fauna and flora species ${ }^{180}$ and the conservation status of the habitats is mostly unfavourable (Figure 41). Threatened species in the wider landscape outside the protected areas are not sufficiently protected.

The Marine Strategy for the Netherlands part of the North Sea, part 1 (2012-2020) contains a policy objective of protecting $10-15 \%$ of the seabed against noticeable disturbance by 2020 . Fisheries measures to reach that

180 https://www.pbl.nl/sites/default/files/cms/publicaties/pbl-2017-lerendeevaluatie-van-het-natuurpact-1769.pdf 
Conservation status of habitat types in the EU 27, 2007-2012

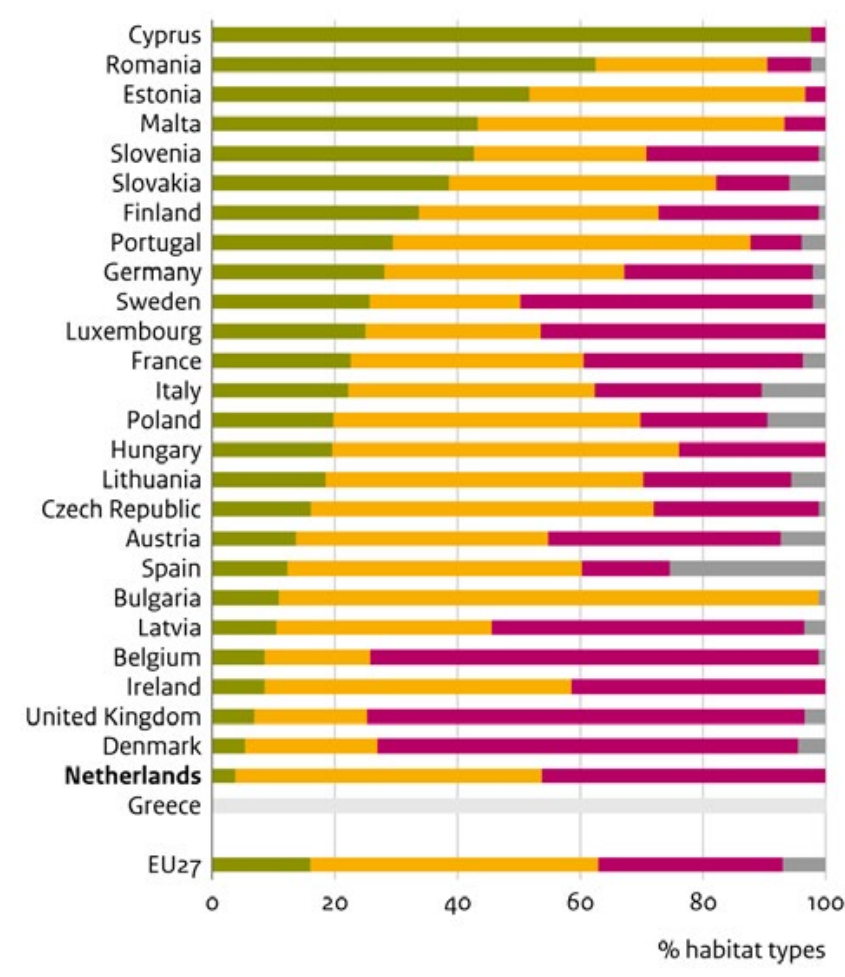

Source: Annexes State of Nature report
Favourable

Unfavourableinadequate

Unfavourable

Unknown

No data

Figure 41. Conservation status of habitat types in the EU Member States and the EU average

goal are currently under development. Furthermore, under the OSPAR Regional Seas Convention the Netherlands works with other countries to develop an ecologically coherent, representative and well managed network of MPAs. ${ }^{181}$

\section{Caribbean contribution to the achievement of Aichi Targets 11}

The minimum required protected area of $17 \%$ of the terrestrial and inland water area and $10 \%$ of coastal and marine waters may be achieved for the islands of the Caribbean Netherlands, but the conservation and management status of these areas is still a concern, which means that this target has not yet been achieved.

The Bonaire island zoning plan provides protection to $17 \%$ of the land surface as terrestrial nature park or reserve. In addition, a large part of the island (approx. 40\%) has

181 https://www.noordzeeloket.nl/beleid/europese/achtergrond/documentenmariene/@166937/marine-strategy-0/ and https://www.ospar.org/site/assets/ files/1378/assessment_sheet_mpa_status_2017.pdf been designated as a conservation area and is protected from any development. On Sint Eustatius $27 \%$ of the land surface is protected as terrestrial nature park and a large additional part of the island is designated as a conservation area and protected from development. On Saba 3.1\% of the land is protected as a nature park and all the land above $550 \mathrm{~m}$ is protected from development. Saba passed legislation to establish a new National Park comprising $25 \%$ of its land area in September 2018. Around the islands the marine protected areas include $100 \%$ of the coastal waters. The Saba Bank MPAs comprise $22.5 \%$ of the total sea area around Saba and Sint Eustatius. The Yarari Sanctuary for marine mammals and sharks comprises all the territorial waters and the EEZ of Bonaire, Sint Eustatius and Saba.

\section{Aruba}

Currently $27 \%$ of the terrestrial and inland water area and $5 \%$ of the coastal and marine areas of Aruba are conserved and effectively managed. Aruba is currently in the process of designating a Marine Park and increasing the 
number of Ramsar Wetlands from 1 to 5 . Arikok National Park was officially established in 2000 to protect and preserve the area's flora, fauna, geology and historical remains. It is located on Aruba's north-eastern shore. In 2017 the south-eastern Spaans Lagoen (a marine lagoon and Ramsar site) was enlarged to 271 ha, partly restored and included within the National Park. This created a roughly 2,700 ha protected area, which covers some $20 \%$ of the island's total land area. The department of nature and the environment is in the process of designating more terrestrial and marine protected areas. Management of the protected areas is still a concern as threats from livestock grazing and invasive species (e.g. the boa constrictor) are not sufficiently controlled. Many extinctions can be expected in the coming decades as there is zero recruitment of young trees to replace old dying trees.

\section{Curaçao}

Management plans are available for all conservation areas and the island land use and zoning plan protects conservation areas, which cover about $30 \%$ of the surface of the island. Recent legal designation of four Ramsar protected areas is a valuable step forward ${ }^{182}$, and a fifth site, Klein Curaçao, was designated in September 2018. Curaçao also intends to designate the Curaçao Underwater Park as a world heritage site (in combination with the Bonaire Marine Park). This park is located off Curaçao's south-east coast. It stretches along 20 kilometres of shoreline from the high water mark to a depth of $60 \mathrm{~m}$. It includes 600 ha $(6 \mathrm{~km} 2)$ of fringing reefs as well as 436 ha of inland bays with mangroves and seagrass beds.

Christoffel Park and Shete Boka Park are located in the north-western corner of the island. Together they encompass 2,800 ha of evergreen woodland, coastal lagoons with seagrass beds and mangroves, and dry deciduous shrubland. However, Ramsar designation does not mean that the areas are free from pressures, such as uncontrolled tourism. Progress has been made on the management of the Ramsar sites. Management plans are about to be implemented.

In contrast to the progress with Ramsar sites, the Oostpunt Development Plan conflicts with the recommendations and agreements stated in the BEST report to safeguard important and valuable nature area at the

182 Dilrosun, F, Vermeij MJA, Chamberland VF, 2012. Onderzoek Ramsar gebieden op Curaçao. Strategisch rapport Ministerie Gezondheid, Milieu en Natuur, Willemstad, Curacao. 157pp.
Oostpunt. Despite all the ecological interest and importance of the Oostpunt natural area, with its regionally important reefs, this area is threatened following a government plan to rezone the area and allow commercial development in sensitive and valuable coastal and terrestrial areas.

\section{Sint Maarten}

Mullet Pond, the last intact mangrove ecosystem on the Dutch side of the island, was designated under the Ramsar Convention in 2016. Only the MPA is to be listed under UNESCO's Man and the Biosphere (MAB) Programme. Mullet Pond and five other sites (Fort Amsterdam, Great Salt Pond, Emilio Wilson Estate, Geneve Bay and Little islands) are proposed for listing under the MAB Programme.

The Man of War Shoal Marine Park (2010, 3,100 ha) includes the island's most important reefs and provides a safe haven for whales, sharks, sea turtles and hundreds of species of fish. It includes a range of habitats from coral reefs to seagrass beds and open water. Under SPAW, and specifically related to the Man of War Shoal Marine Park, corals and seagrass beds are targeted for more management, recovery and protection measures than others. Under BEST III (2016), Key Biodiversity Areas (KBAs) have been defined to secure conservation outcomes. Currently, there is no terrestrial area protected on Sint Maarten. A project to form a terrestrial park is underway at Emilio Wilson Estate and Geneva Back Bay and will form, with the Marine Park, a National Park system (Sint Maarten proposed Land Parks management plan, Sint Maarten Nature Foundation 2009). 
Target 12

Reducing risk of extinction

By 2020, the extinction of known threatened species has been prevented and their conservation status, particularly of those most in decline, has been improved and sustained.

\section{Why is this target important?}

Reducing the threat of human-induced extinction requires action to address the direct and indirect drivers of change. Achievement of this target is therefore highly dependent on most of the other Aichi Biodiversity Targets.

Nevertheless, imminent extinctions of known threatened species can in many cases be prevented by protecting the sites where such threatened species are located, by combating particular threats, and through ex situ conservation $^{183}$.

\section{Summary of progress towards the target}

Aichi Targets 12 has not yet been achieved. Although the number of threatened species as well as their threatened status has improved slightly over the past decade, this recovery has proved to be fragile. Agricultural biodiversity in particular is most threatened. Progress towards Aichi Targets 12 in the Caribbean Netherlands is assessed as 'progress towards target but at an insufficient rate'. Progress in Aruba is assessed as 'moving away from target' and in Curaçao and Sint Maarten as 'no significant change'.

\section{Dutch contribution to the achievement of Aichi Targets 12}

The Netherlands fully implements the EU Habitats and Birds Directives, which seek to preserve biodiversity by protecting wild flora and fauna and their habitats. The Member States designate Special Protection Areas (Natura 2000 sites) and protect plant and animal species and habitat types listed in the Annexes of the Directives. In the Netherlands most Natura 2000 sites are fully included in the NEN which also contains other protected habitats for species conservation. Many measures have been taken (see section II) to create and restore habitats, reduce

183 Global Biodiversity Outlook A mid-term assessment of progress towards the implementation of the Strategic Plan for Biodiversity 2011-2020 habitat fragmentation and improve environmental conditions, both within and outside the NEN. The effects of these measures are reported to the EC every six years in an assessment of the conservation status of the habitat types and/or species that are listed in the Annexes to the Directives. The latest assessment (2013) showed that the measures are still not sufficient. Only $23 \%$ of the species and $4 \%$ of the habitat types listed in the Habitats Directive had a favourable conservation status; the remainder were considered unfavourable-inadequate or unfavourable-bad (see National Target 1 , section IV-1).

The Dutch Living Planet Index (LPI) (Figure 6, section III-3) has increased by $7 \%$ since 1990 . The LPI shows the average trend in the population size of the native (non-marine) species of breeding birds, mammals, reptiles, amphibians, butterflies, dragonflies and freshwater fish. The increase is mainly due to an improvement in freshwater and marsh habitats.

The number of Red List species increased rapidly in the Netherlands between 1950 and 1995 and then more slowly until 2005. Among all vertebrates, plants and some major groups of invertebrates, approx. $40 \%$ of the species are, to some extent, threatened with extinction at the national level (Figures 42 and 43). After 2005 the number of Red List species has fallen slightly and their overall population status has improved a little. In particular, species of vascular plants, dragonflies and mammals are less threatened compared with 1995 (figure 44). However, since 2017 the number of Red List species has increased again and their overall population status has worsened, which shows that recovery is still fragile.

Threatened species are not limited to protected areas and so the Nature Conservation Act applies outside protected areas as well. Every proposed development should be carefully planned and take measures to minimise effects on protected species and their nests, burrows, etc. Many species are protected by specific measurements taken by NGOs and many volunteers, such as protecting the nests of farmland birds or helping toads to cross roads safely during the spring migration to their reproduction pools. Threatened species are found in all ecosystems, but the greatest threat is to agricultural biodiversity. For example, numbers of farmland birds have decreased on average by more than $50 \%$ since the 1960 s, and some species numbers have even fallen by more than $90 \%$ (see Aichi Targets 7). 


\section{Percentage of threatened species}

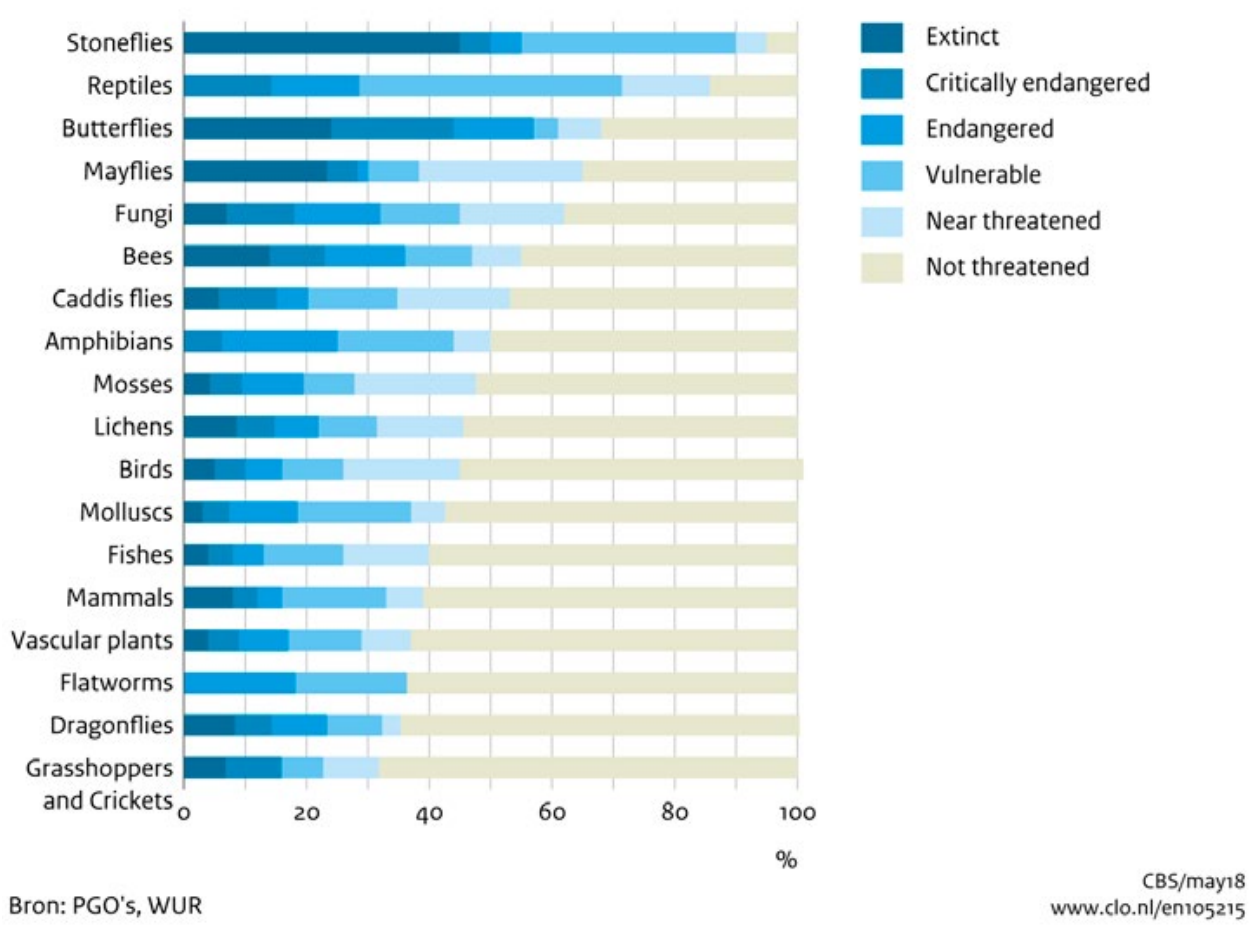

Figure 42. Percentage of threatened species per species group in the Netherlands

\section{Red List species and non-endangered species}

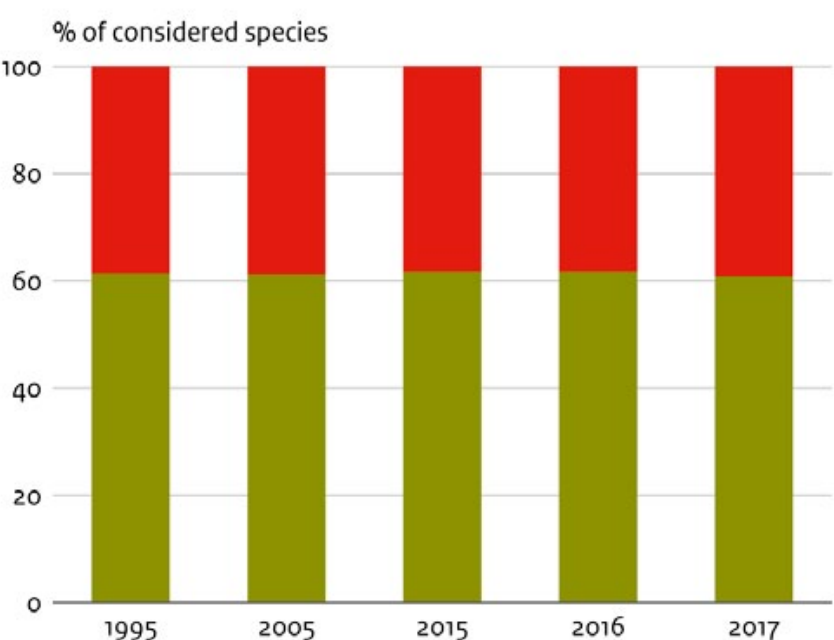

Source: NEM (Statistics Netherlands \& PGO's)
CBS/may18 www.clo.nl/en152111

Figure 43. The percentage of species in the Netherlands on the Red List is just under $40 \%$ 


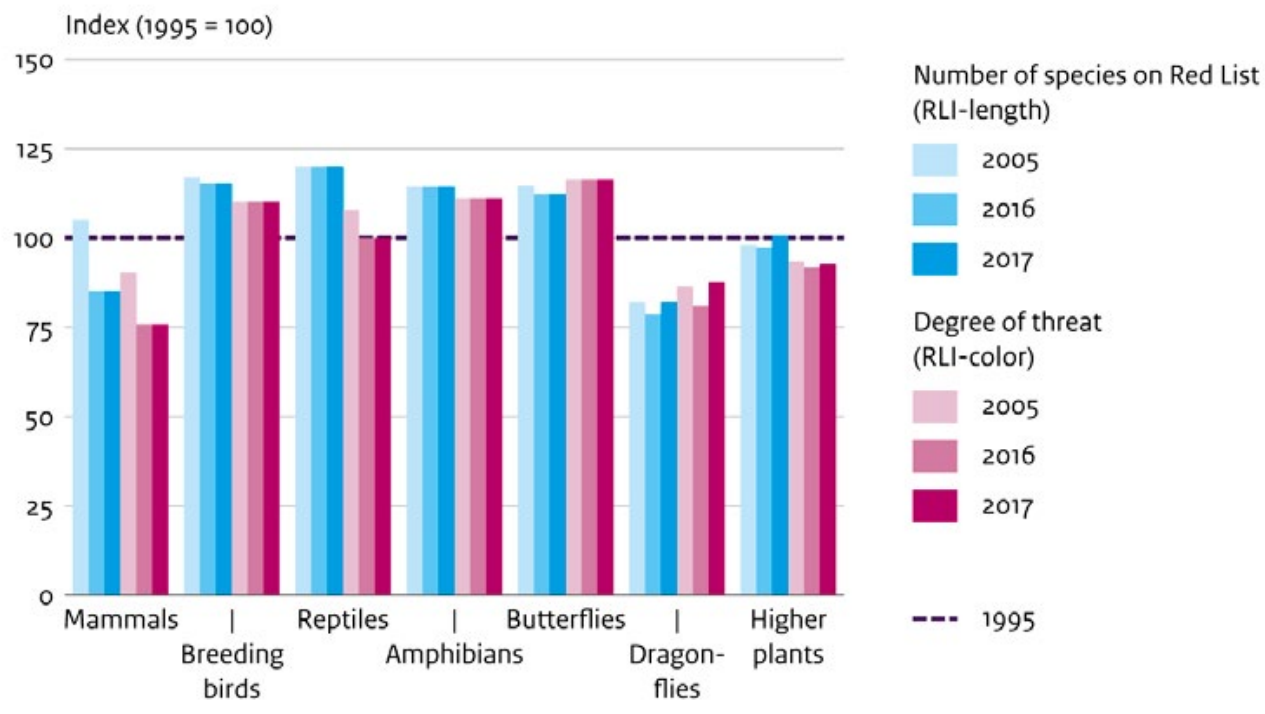

Figure 44. Trend in Red List species and degree of threat per species group in the Netherlands

\section{Caribbean contribution to the achievement of Aichi Targets 12}

To date, 66 species (data 2017) are listed as threatened, of which six are Critically Endangered (CR), 18

Endangered (EN) and 42 Vulnerable (VU). No less than $75 \%$ of the threatened species depend completely or for most of their life cycle on marine habitat (e.g. marine turtles). Many can be considered transboundary species which indicates that cooperation with other Caribbean states is needed to improve or sustain species populations. An assessment of the state of nature in the Caribbean Netherlands revealed that the conservation status of all 11 marine and terrestrial habitats and the 12 assessed species groups was inadequate or very inadequate. All threatened species listed in the annexes of the SPAW Protocol are similarly protected in the Caribbean Netherlands as well as on Aruba, Curaçao and Sint Maarten. Bonaire fully protects all threatened flora and fauna species on the island. Saba has now also adopted a comprehensive list of protected species. On Sint Eustatius a dedicated conservation programme targets the critically endangered Antillean iguana (Iguana delicatissima). The Bonaire NGO Echo, in cooperation with the island government, runs a dedicated conservation programme for the endangered yellow-shouldered Amazon parrot (Amazona barbadensis) and the population has been gradually increasing since conservation efforts started some 15 years ago.
The Netherlands actively participates in the InterAmerican Convention (IAC) for the protection of sea turtles on behalf of the Caribbean Netherlands and sea turtle conservation is targeted by the dedicated NGO STCB as well as by the Sint Eustatius National Park Foundation. Since active protection started some 20 years ago, sea turtle nesting trends on Bonaire have been rising.

\section{Aruba}

On 15 August 2017 Aruba published a list of protected flora and fauna species under the Nature Protection Act. Aruba has two documented animal extinctions. These are the scaly-naped pigeon (Patagioenas squamosa) and the yellow-shouldered Amazon parrot (Amazona barbadensis). Unless measures are taken to control feral grazers and the voracious boa constrictor snake (Boa constrictor), more extinctions can be expected. One area of advancement is in sea turtle protection, headed by the NGO TurtugAruba. Improved conditions in wetlands and reduced hunting disturbance have allowed the population of the Caribbean coot (Fulica caribbaea) to recover and expand ${ }^{184}$.

\footnotetext{
184 Nijman, V., M. Aliabadian, A. O. Debrot, J. A. de Freitas, L. G. L. Gomes, T. G. Prins and R. Vonk. 2008. Conservation status of Caribbean coot Fulica caribaea in the Netherlands Antilles, and other parts of the Caribbean. Endangerd Species Research 4: 241-246.
} 


\section{Curaçao}

Curaçao has not yet published a list of protected flora and fauna species. No recent extinctions have occurred or are imminent. The last extinctions took place during the early colonial period (Caribbean monk seal, native rice rat and possibly the yellow-shouldered parrot). Since 2014 the NGO STCC has been increasingly active in sea turtle conservation on the island.

\section{Sint Maarten}

Sint Maarten has not yet published a list of protected flora and fauna species. The two endemic land plants of Sint Maarten have not been documented for about 50 years, and are probably extinct. The West Indian manatee can no longer maintain itself and, crucially, cannot use the Simpson Bay lagoon and the last sighting record is from many years ago. The introduction of the mongoose has led to a decline in land birds and probably to the extinction of the endemic snake Alsophis reijersmai. The Lesser Antillean iguana is probably extinct, or at best genetically degraded by the introduction of the green iguana. The loss of terrestrial biodiversity is likely to continue due to habitat loss and the effects of introduced species.

The Man of War Shoal Marine Park is a home and migratory stopover or breeding site for 3 IUCN Red List Species, 10 Convention on International Trade in Endangered Species (CITES) Appendix I species and 89 Appendix II species. It is an area with a healthy population of marine mammals, including migratory whales and dolphins, numerous species of shark, sea turtles and fish species.

\section{Dutch contribution to the achievement of Aichi Targets 12 at a global level}

The conservation of species depends also on international cooperation on measures such as the establishment of an MPA in the Sargasso sea, the nursery ground of European eel, and the defragmentation of rivers to allow migratory fish species like Atlantic salmon and Atlantic sturgeon to reach their nursery grounds. The Netherlands has agreed to partially open several sluices in the Haringvlietdam, which closes off one of the main sea arms in the estuary of the rivers Meuse and Rhine. This decision (Kierbes/uit) was agreed in 2011 and the measures will be finalised in 2018. Another example of international cooperation is the prevention of the extinction of the fire salamander (Salamandra salamandra) in the Netherlands after a fungal infection nearly killed the entire national population.
The Netherlands has been instrumental in the listing in the SPAW Protocol of the three most endangered coral species in the Caribbean, Acropora spp. and Orbicella spp., as well as eight shark and ray species. All marine mammals observed in the Lesser Antilles and Leeward Islands are listed in Annex II of the SPAW Protocol of the Cartagena Convention and Appendix I or II of CITES as species in danger of extinction that are or may be threatened by trade, and in the CMS list (Convention on the Conservation of Migratory Species of Wild Animals). 


\section{By 2020 , the genetic diversity of cultivated plants and farmed and domesticated animals and of wild relatives, including other socioeconomically as well as culturally valuable species, is maintained and strategies have been developed and implemented for minimising genetic erosion and safeguarding their genetic diversity.}

\section{Why is this target important?}

Genetic diversity offers options for increasing the resilience of agricultural systems and for adapting to changing conditions, including the escalating impacts of climate change. Genetic diversity is also an important component of cultural heritage. Maintaining this diversity requires conservation of the many varieties of cultivated plants and breeds of domesticated livestock bred by farmers over thousands of years and of the wild relatives of crops whose traits may be essential for future plant breeding and thus underpin food security ${ }^{185}$.

\section{Summary of progress towards the target}

Aichi Targets 13 is still a concern. Although considerable efforts have been made to conserve the native livestock breeds and crops, many breeds are still at risk. Progress towards Aichi Targets 13 in all overseas territories in the Caribbean is assessed as 'not applicable'. Agro-genetic biodiversity is not an issue on any of the six Dutch Caribbean islands and/or countries.

\section{Dutch contribution to the achievement of Aichi Targets 13}

The intensification of agriculture has resulted in an erosion of the genetic crop diversity in Dutch farming systems and production processes are dominated by a few commercial crops. Genetic diversity is now largely conserved in ex situ collections in the Netherlands and abroad (e.g. the Svalbard Global Seed Vault at Spitsbergen). Plant genetic resources (such as crops) in the Netherlands are not at risk.

The status of many Dutch animal breeds is vulnerable or even critical. The status and trends in agro-genetic

185 Global Biodiversity Outlook A mid-term assessment of progress towards the implementation of the Strategic Plan for Biodiversity 2011-2020 biodiversity in the Netherlands clearly indicate that most native breeds of cattle, horse, sheep, goat and other animals are currently still at risk because of their very small population size. Populations of native breeds, although generally well adapted to local circumstances and resources, remain in critically low numbers and have been replaced by a few widespread and highly productive breeds. New uses for these species are currently being created. For example, the dairy cattle breed Groninger Blaarkop is used in sustainable farming systems, for the production of regional food products and as a grazer in conservation management. It is particularly suitable for grazing low productive natural or semi-natural grassland. However, Dutch farmers are currently faced with the need to reduce the number of dairy cows to meet phosphorous emission standards. They were unable to obtain exemptions for rare native breeds, which puts these breeds even more at risk. Other ways are being sought to subsidize the keeping of these breeds. ${ }^{186}$

The Centre for Genetic Resources, the Netherlands (CGN) and the Dutch Rare Breed Survival Trust (SZH) are the main organisations working for the conservation of agro-genetic biodiversity. In 2002, the policy document Sources of Existence ${ }^{187}$ (Min. LNV et al., 2002) described the strategy and policy development in relation to genetic resources management. This document describes the tasks and responsibilities of CGN: to advise on the development and implementation of international policies on genetic resources conservation and their exchange and use in various international fora. The CGN, founded in 1985 , is responsible for the genetic resources programme to conserve ex situ resources of plants and animals, support conservation of in situ resources, and stimulate the use of genetic resources on behalf of breeding and research as part of our cultural heritage. The CGN also provides policy support to the Dutch government.

The Dutch government financially supports the Dutch Rare Breed Survival Trust (SZH). The trust was founded in 1976 in response to the diminishing variety of traditional breeds, of which some were already threatened by extinction at that point. The trust makes an effort to raise awareness and exchange knowledge, and organises actions to maintain native breeds.

186 https://www.tweedekamer.nl/kamerstukken/ detail id $=2018 Z 13431 \&$ did $=2018$ D 38242

187 Min. LNV, 2002. Bronnen van ons bestaan - behoud en duurzaam gebruik van genetische diversiteit. 30p. 


\title{
Strategic Goal D
}

\author{
Enhance the benefits to all from biodiversity and ecosystem services
}

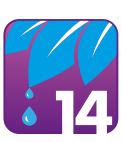

\section{Target 14 \\ Ecosystem services}

By 2020, ecosystems that provide essential services, including services related to water, and contribute to health, livelihoods and well-being, are restored and safeguarded, taking into account the needs of women, indigenous and local communities and the poor and vulnerable.

\section{Why this target is important?}

All terrestrial, freshwater and marine ecosystems provide multiple ecosystem services. However some ecosystems are particularly important in that they provide services that directly contribute to human health and wellbeing by providing services and goods to fulfil daily physical, material, cultural and spiritual needs. This target directs attention towards the need for policies to focus specifically on restoring and safeguarding such ecosystems, thus linking biodiversity conservation with goals related to sustainable development and the needs of the poor, women and indigenous and local communities ${ }^{188}$.

\section{Summary of progress towards the target}

Progress has been made with the restoration of ecosystem services, especially along rivers and streams. However, the exact extent and economic and social value of the full array of ecosystem services is still not fully understood (see also National Target 2 section IV-2). Progress towards Aichi Targets 14 in the Caribbean Netherlands, Aruba, Curaçao and Sint Maarten is assessed as 'moving away from target'.

\section{Dutch contribution to the achievement of Aichi Targets 14}

Despite the current interest in essential ecosystem

188 Global Biodiversity Outlook A mid-term assessment of progress towards the implementation of the Strategic Plan for Biodiversity 2011-2020 services, analysis and evaluation of ecosystem services is still at an early stage, as is the process of restoring and safeguarding them. ${ }^{189}$ One of the actions of the Natural Capital Agenda is the development of the digital Atlas of Natural Capital in the Netherlands, which will be the basis for developing policy strategies to map ecosystem services, applying TEEB and restoring and safeguarding essential ecosystem services. In section IV-2 we presented a few services (pollination and water storage along rivers) which have received special attention.

\section{Caribbean contribution to the achievement of Aichi Targets 14}

The TEEB studies on Bonaire, Saba and Sint Eustatius identified essential services provided by the ecosystems on and around the islands, especially coral reefs for their essential services to tourism, coastal protection and as fish nurseries. The reefs are under severe threat from climate change as well as local impacts of pollution and sedimentation. The 2017 state of nature assessment of the Caribbean Netherlands ${ }^{190}$ revealed that the coral cover on all three islands has substantially decreased in recent decades (see Figure 45). The 2017 conservation status of the coral reefs in the Caribbean Netherlands was assessed as 'unfavourable-bad'. All other habitats were also considered unfavourable-insufficient or unfavourable-bad (see Aichi Targets 5).

\section{Aruba}

The TEEB study for Aruba ${ }^{191}$ (2018) revealed that Aruba's natural capital value for tourism, culture, fishing and carbon exceeds USD 287.3 million per year. Aruba depends on tourism, which accounts directly for $28.6 \%$ of total GDP. Combined with indirect returns, tourism accounts for $88.1 \%$ of total GDP and is expected to reach $97.4 \%$ by 2027 . As tourism depends on the conservation and management of the marine environment, Aruba's

\footnotetext{
189 https://themasites.pbl.nl/natuurlijk-kapitaal-nederland/wp-content/ uploads/2014/PBL_2016_Natuurlijk-kapitaal_1455.pdf

190 http://edepot.wur.nl/183506

191 https://www.wolfscompany.com/

teeb-aruba-the-economics-of-ecosystems-and-biodiversity/
} 


\section{Coral cover}

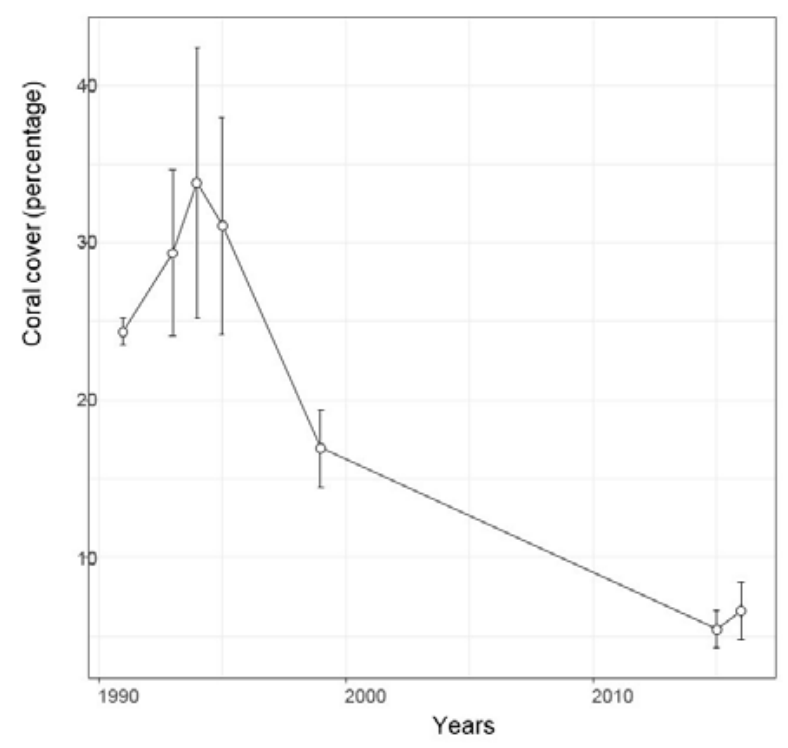

Figure 45. Coral cover around Bonaire, Saba and Sint Eustatius has been decreasing since the 1990s

welfare could halve if its marine environment is degraded (TEEB Aruba, 2018). There are ambitions to expand the Arikok National Park by including additional terrestrial and marine areas. However, no MPAs have been designated yet.

\section{Curaçao}

The oil refinery, trade and tourism form the engine of Curaçao's economy. Tourism in particular depends heavily on ecosystem services provided by the marine environment, including the island's beaches (swimming and sunbathing), coral reefs (diving) and fish (food). Curaçao will designate the approximately 1,000 ha Curaçao Underwater Park, but for most of the marine environment the pressures continue to mount. Illustrative of the situation is that the tourism master plan for 2015-2020 makes no mention of integrating biodiversity values.

\section{Sint Maarten}

The economy of Sint Maarten is highly dependent on tourism, which in turn depends on ecosystem services provided by the marine environment, including the island's beaches (swimming and sunbathing), coral reefs (diving) and fish (food). An estimation has been made by the Nature Foundation of the value of ecosystem services of Mullet Pond (such as its fish nursery function and the prevention of coastal erosion), one of the last areas of intact or near-intact mangrove ecosystem left on the Dutch side of the island. The ecosystem contributes USD 792,000 annually to the local economy (based on the World Resources Institute's Economic Value of Ecosystems model). Mullet Pond supports not only the ecosystems in situ, but also the biodiversity of Sint Maarten's coastal waters, including the Man of War Shoal Marine Park. It functions as a nursery area for numerous fish species and is also the most significant storm refuge for numerous bird, fish and reptile species. Studies of the Man of War Shoal Marine Park have shown that biodiversity in this area, particularly coral reef coverage, is high and the economic goods and services which the ecosystem provides are in excess of USD 50 million annually. The 2017 hurricane season had a devastating impact on the marine and terrestrial environment, although the extent of the impact is not yet clear.

\section{Dutch contribution to the achievement of Aichi Targets 14 at a global level}

Internationally the Dutch Ministry of Foreign Affairs and its embassies, other Dutch government departments, water authorities, civil society organisations, knowledge institutes and companies support various programmes that promote protection and sustainable use of ecosystems. 


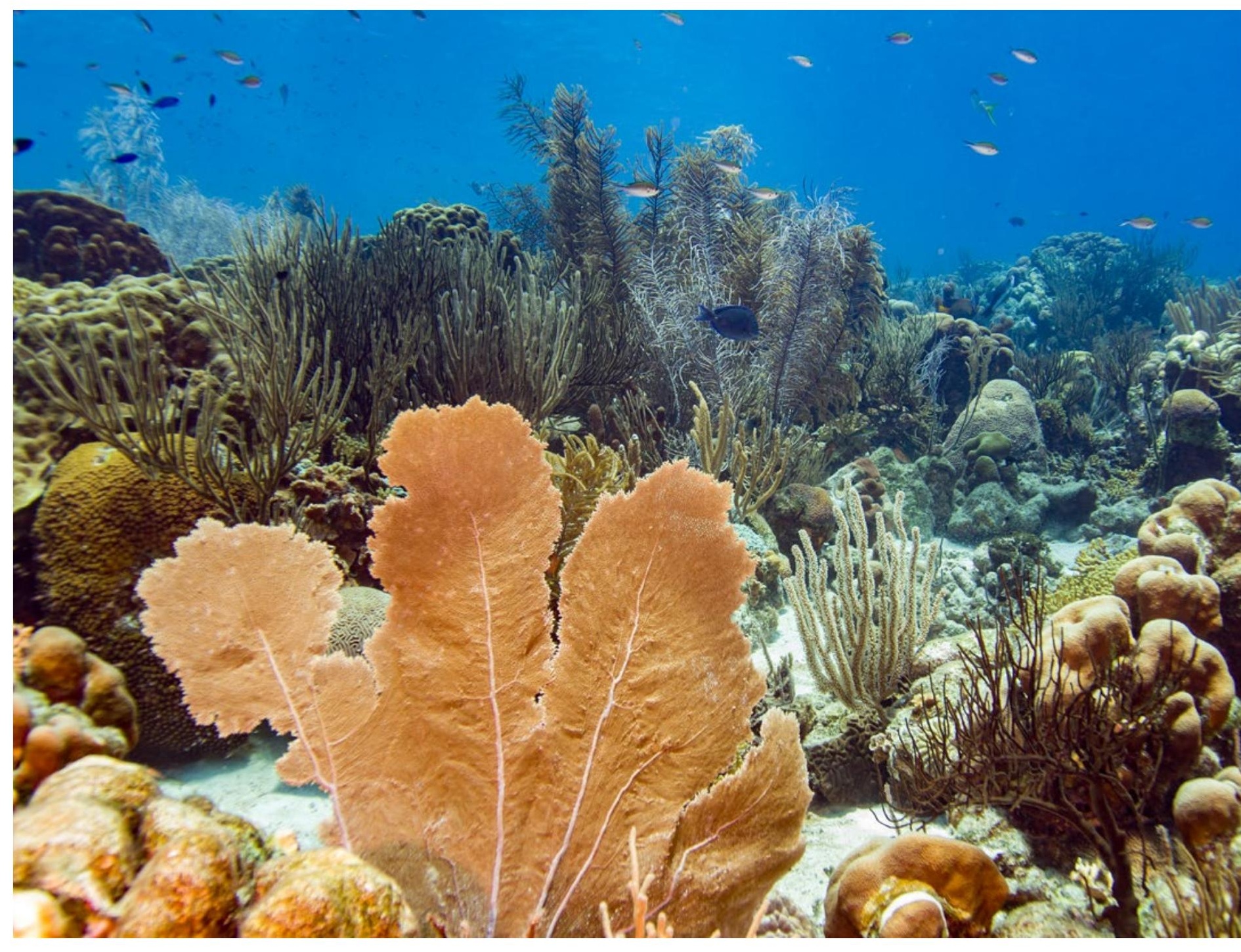

The challenge is to integrate the values of ecosystem services into government policies. Several of these programmes combine participatory land use planning that is guided by science, integrated water resources management, promotion of renewable energy and the facilitation of value chains for sustainable products and services that can be accommodated in climate robust landscapes. Examples of such programmes are IDH's Initiative for Sustainable Land and Water, IUCN's SUSTAIN Africa programme, which aims to make economic growth corridors in Africa more sustainable, and a programme of the Horn of Africa Regional Environment Centre and Network for sustainable development of the Rift Valley and the cross-border Boma-Gambella Landscape in SouthWest Ethiopia and South Sudan. The latter landscape contains an informal economic growth corridor where there is considerable agricultural development, but also a still rather unknown ecosystem with an annual migration of about 850,000 white-eared kob deer and many other wild animals, including large mammals like elephant and giraffe, and which has ecotourism development poten- tial $^{192}$. A midterm evaluation of 2017 is available on the website $^{193}$. Other examples include the Ecosystem Alliance programme (a collaboration between IUCN NL, Both ENDS and Wetlands International) ${ }^{194}$ supporting civil society in 16 countries in the tropics and subtropics with the aim of improving ecosystem management for the benefit of local communities. The programme was carried out from 2011 to 2015 .

192 http://www.waterandnature.org/initiatives/sustain

$193 \mathrm{http}: / /$ www.waterandnature.org/sites/default/files/2017_06_13_final_report_ of_mtr_of_sustain.pdf

194 https://www.bothends.org/en/Our-work/Dossiers/

The-Ecosystem-Alliance-creating-a-green-and-inclusive-economy 
Target 15

Ecosystem restoration and resilience

By 2020, ecosystem resilience and the contribution of biodiversity to carbon stocks have been enhanced through conservation and restoration, including restoration of at least 15 per cent of degraded ecosystems, thereby contributing to climate change mitigation and adaptation and to combating desertification.

\section{Why is this target important?}

The reversal of habitat loss, fragmentation and degradation through ecosystem restoration represents an immense opportunity for both biodiversity restoration and carbon sequestration. Restored landscapes and seascapes can improve resilience, including the adaptive capacity of ecosystems and societies, contributing to climate change adaptation and generating ecosystem services and associated benefits for people, in particular indigenous and local communities and the rural poor ${ }^{195}$.

\section{Summary of progress towards the target}

Aichi Targets 15 has not yet been achieved, mainly due to degraded peatland areas. Awareness is growing that the large array of peatland meadows should be transformed from carbon emitting areas into carbon sequestration areas. Restoration pilots are planned and some are underway. Progress towards Aichi Targets 15 in the Caribbean Netherlands, Aruba, Curaçao and Sint Maarten is assessed as 'moving away from target'.

\section{Dutch contribution to the achievement of Aichi Targets 15}

Much is being done to complete and manage the NEN, including all Natura 2000 sites. This means restoration or reconversion of land into natural ecosystems and defragmentation of natural habitat. The conversion of land into natural ecosystems will result in additional carbon sequestration. The conservation management plans and all efforts to minimise the anthropogenic pressures will eventually enhance the resilience of ecosystems. The measures under the EU Water Framework Directive and the Delta Programme will also enhance the resilience of

195 Global Biodiversity Outlook A mid-term assessment of progress towards the implementation of the Strategic Plan for Biodiversity 2011-2020 wetlands in the Netherlands. The ambitious policy for the large waters of the Netherlands Delta is to restore natural processes, improve biodiversity and adapt to climate change ${ }^{196}$. This process will continue beyond 2020 .

Forests and peatlands are the main ecosystems with potential for carbon sequestration. All forests are legally protected and sustainably managed. Forests and other vegetation annually capture almost 3.6 Mtonnes of $\mathrm{CO}_{2}$ from the atmosphere and store it in the form of biomass, which compensates $2 \%$ of annual Dutch $\mathrm{CO}_{2}$ emissions ${ }^{197}$. However, the ongoing drying out of peatlands, caused mainly by drainage and the lowering of water tables for agricultural reasons, leads to emissions of around 7 Mtonnes of $\mathrm{CO}_{2}$ each year, almost twice as much. Current progress on this Aichi Targets is limited and greatly depends on the ability to restore peatlands and to transform them from carbon emitting into carbon sequestering areas. Peat soils emit a lot of carbon per hectare (Figure 46). The greenhouse gas balance of restored peatlands depends on the vegetation type, water level, level of fertilisation and other factors. This is a complex interaction which is not fully understood yet. A website has been developed where all knowledge on restoring and maintaining all values of peat areas is collected and published. The website also contains information about measures that might reduce subsidence and $\mathrm{CO}_{2}$ emissions. ${ }^{198}$ Restoration of peatlands in Natura 2000 sites is included in the Natura 2000 management plans.

\section{Caribbean contribution to the achievement of Aichi Targets 15}

Restoration efforts are small-scale and insufficient to restore the terrestrial and marine ecosystems.

Currently Bonaire is engaged in a successful small-scale reforestation project on the island of Klein Bonaire and in the Washington Slagbaai National Park. Overgrazing by goats is reduced, followed by reforestation in exclosures. Outside the park a larger reforestation effort is underway to plant 20,000 trees in 20 one hectare enclosures. A small-scale Acropora coral restoration project has been piloted on Bonaire and is now expanding with more nursery sites as well as outplanting sites. On Saba and

196 https://www.rijksoverheid.nl/documenten/publicaties/2013/10/31/ beleidsverkenning-natuurambitie-grote-wateren-2050-2010

197 Lof et al., 2017. The SEEA EEA carbon account for the Netherlands, CBS \& WUR; https://www.cbs.nl/en-gb/background/2017/45/ the-seea-eea-carbon-account-for-the-netherlands

198 http://www.veenweidegebieden-oras.nl/Maatregelen/Verminderen_van_ maaivelddaling_en_van_CO2_emissie.aspx 


\section{Carbon emissions}

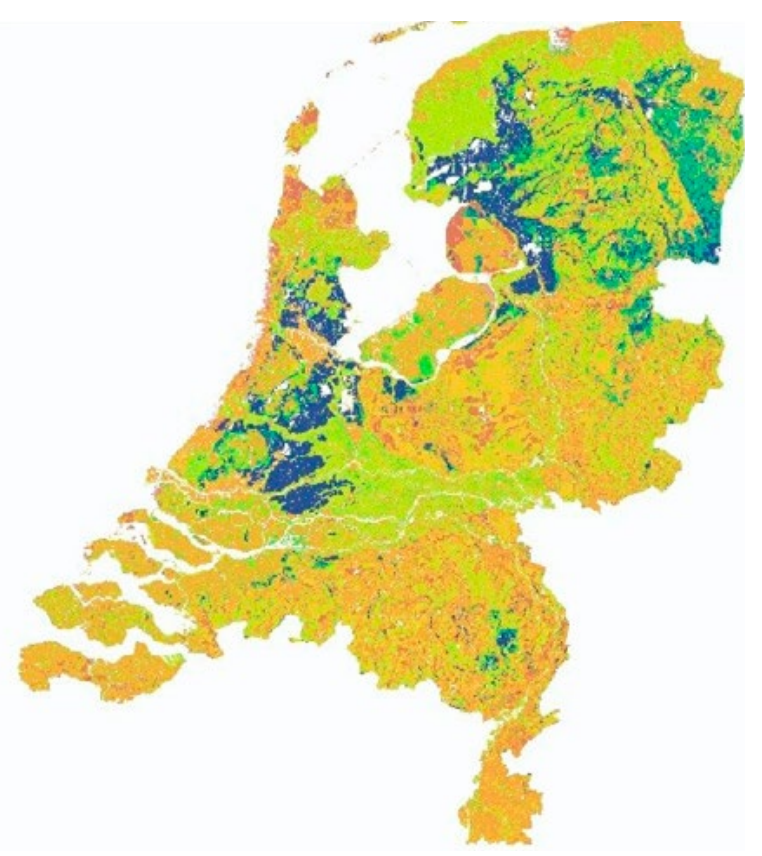

Figure 46. Carbon emissions in the Netherlands (Lof et al., 2017) (199 $^{9}$

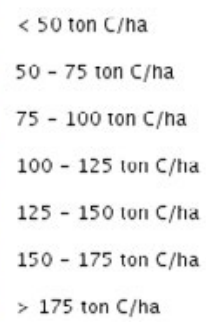

Sint Eustatius similar coral restoration efforts are targeting the endangered staghorn and elkhorn corals (Acropora spp.) have started, but were severely set back by hurricanes Irma and Maria. On Bonaire an ecological water circulation restoration project has started in the Lac Ramsar site to maintain the health of the mangrove forests and the nursery function of the lagoon.

\section{Aruba}

A small-scale restoration project in the Spaans Lagoen Ramsar site was carried out in 2016-2017 and a small mangrove reintroduction project was carried out on the keys in front of Oranjestad harbour. However, most progress on this target could be achieved by restoring mangrove forests and removing the free-roaming livestock (mainly goats) to allow regrowth of the dry tropical forests.

\section{Curaçao}

Successful reforestation projects for threatened tree species have been carried out on the islet of Klein
Curaçao. Also, over a nine-year period about 100,000 mangrove trees were planted in six bays. Nevertheless, key mangrove, seagrass and fish nursery areas continue to decline due to mounting recreational pressures (e.g. Spaanse Water). Most progress on this target could be achieved by restoring mangrove forests and removing the free-roaming livestock (mainly goats) to allow regrowth of the dry tropical forests.

\section{Sint Maarten}

There are plans to increase the number of terrestrial and protected areas. However, most progress on this target could be achieved by restoring mangrove forests.

\section{Dutch contribution to the achievement of Aichi Targets 15 at a global level} The Ministry of Economic Affairs and the Ministry of Infrastructure and Environment support the degraded land restoration projects of Commonland. ${ }^{200}$ Commonland provides a holistic approach to large-scale land restoration that delivers ' 4 returns' on investment: inspiration, social capital, natural capital and financial capital. Landscape 


\section{Target 16}

Access to and sharing benefits from genetic resources

\author{
By 2015, the Nagoya Protocol on Access to Genetic \\ Resources and the Fair and Equitable Sharing of Benefits \\ Arising from their Utilisation is in force and operational, \\ consistent with national legislation.
}

\section{Why is this target important?}

The fair and equitable sharing of the benefits arising from the utilisation of genetic resources is one of the three objectives of the CBD. The Nagoya Protocol, adopted in 2010, provides a transparent legal framework for the effective implementation of this objective. The Protocol covers genetic resources and associated traditional knowledge, as well as the benefits arising from their utilisation, by setting out core obligations for its contracting Parties to take measures in relation to access, benefit sharing and compliance. Bringing this Protocol into force and making it operational within countries is an important target for implementing the Strategic Plan for Biodiversity 2011-2020 and for achieving the third objective of the Convention $^{202}$.

\section{Summary of progress towards the target}

Aichi Targets 16 has been achieved. Progress towards Aichi Targets 16 in the Caribbean Netherlands is assessed as 'progress towards target but at an insufficient rate'. Progress in Aruba, Curaçao and Sint Maarten is assessed as 'no significant change'.

\section{Dutch contribution to the achievement of \\ Aichi Targets 16}

The Nagoya Protocol on Access to Genetic Resources and the Fair and Equitable Sharing of Benefits Arising from their Utilisation is a supplementary agreement to the CBD. Its aim is to ensure the sharing of the benefits arising from the utilisation of genetic resources in a fair and equitable way. It entered into force on 12 October 2014. To implementation the Nagoya Protocol the EU adopted Regulation 511/2014 and the Implementing Regulation EU 2015/1866. In April 2016 the Dutch Nagoya Protocol (Implementation) Act entered into force. The law regu-

202 Global Biodiversity Outlook A mid-term assessment of progress towards the implementation of the Strategic Plan for Biodiversity 2011-2020 lates the direct implementation of the European regulations. Users of genetic resources must investigate whether the country of origin of the genetic source has established access rules. Users may be required to obtain permission from the national authority and may have to make fair agreements with the supplier concerning the benefits arising from the use of the genetic source or traditional knowledge that relates to this genetic source. Information of genetic material covered by the Nagoya Protocol must be collected (tracking and tracing of material) and kept for 20 years. The Centre of Genetic Resources also provides policy support to the Dutch government and is national focal point for ABS.

The Netherlands has completed its interim national report. ${ }^{203}$

\section{Caribbean contribution to the achievement of Aichi Targets 16}

The Nagoya Protocol (Implementation) Act has not yet been implemented in the legislation of the Caribbean Netherlands.

\section{Aruba}

The benefits arising from the use of biodiversity and genetic resources have not been regulated by law.

\section{Curaçao}

Draft policy documents are available, but have not been acted upon by the government (Meesters et al. 2010). This means that the island has missed out on several marine biopharmacy discoveries in recent years and will continue to miss out on this important opportunity unless the matter is attended to.

\section{Sint Maarten}

Draft policy documents are available but have not been yet been submitted for approval by the government (Meesters et al. 2010). The draft policy documents are a Nature Policy Plan and an Environmental Policy Plan. Both will be submitted to the Council of Ministers in 2018.

\section{Dutch contribution to the achievement of Aichi Targets 16 at a global level}

The activities to improve access and fair sharing of benefits are meant to contribute to the achievement of the Aichi Biodiversity Target at the global level.

203 https://absch.cbd.int/countries/NL 


\title{
Strategic Goal E
}

\author{
Enhance implementation through participatory planning, knowledge \\ management and capacity building
}

\section{Target 17 \\ Biodiversity strategies and action plans}

\section{By 2015 each Party has developed, adopted as a policy instrument and commenced implementing an effective, participatory and updated national biodiversity strategy and action plan.}

\section{Why is this target important?}

National biodiversity strategies and action plans (NBSAPs) are the key instrument for translating the Convention on Biological Diversity and the decisions of its Conference of the Parties into national action. The attainment of this target would, therefore, facilitate the achievement of all of the Aichi Biodiversity Targets ${ }^{204}$.

\section{Summary of progress towards the target}

With the current national biodiversity policy papers and action plans in place, Aichi Targets 17 can be considered to have been achieved. Progress towards Aichi Targets 17 in the Caribbean Netherlands is assessed as 'on track to achieve target'. Progress in Aruba and Curaçao is assessed as 'no significant change' and in Sint Maarten 'progress towards target but at an insufficient rate'.

\section{Dutch contribution to the achievement of \\ Aichi Targets 17}

The Netherlands has committed itself to achieving nature objectives in the European biodiversity strategy and thus also indirectly those in the CBD. The conventions, directives and agreements have been implemented in national policy documents and legislation, including the following:

- The Natural Capital Agenda focuses (2013)205, both nationally and internationally, on conservation and sustainable use of biodiversity. The strategy's objective

204 Global Biodiversity Outlook A mid-term assessment of progress towards the implementation of the Strategic Plan for Biodiversity 2011-2020

205 https://www.cbd.int/doc/world/nl/nl-nbsap-v4-p1-en.pdf is to secure resilient ecosystems and ecosystem services that contribute to biodiversity, water and food security, welfare and combating poverty. Developing a natureinclusive economy, securing international biodiversity and the conservation of nature in the Netherlands are important elements of nature policy. The focus of ecosystem services protection lies on the implementation and management of natural capital and sustainable production and consumption, mostly outside the Netherlands.

- The national nature vision The Natural Way Forward Government Vision $2014^{206}$ focuses on the protection and sustainable use of biodiversity in collaboration with citizens, businesses and civil society organisations. These social partners have an increasing say and responsibility to contribute to nature protection and habitat creation. A prominent place is given to the advantages of combining nature protection with other social and economic interests. Citizens, businesses and civil society organisations are encouraged to maximise nature and biodiversity protection in combination with other social and economic interests.

- In the Nature Pact (2013) ${ }^{207}$, the ambitions for the restoration and management of nature in the Netherlands were agreed upon for the period up to and including 2027. The focus of biodiversity protection in the Netherlands lies on the realisation of the NEN, the implementation and management of the EU Natura 2000 sites and the conservation of its Natura 2000 habitat types and species. These sites are part of the NEN, which is due to be completed in 2027. The Dutch government has decentralised the responsibility for habitat restoration and conservation management to the provinces. 


\section{Caribbean contribution to the achievement of Aichi Targets 17}

The NBSAP for the Caribbean Netherlands is the Nature Policy Plan 2013-2017208, which was adopted in May 2013. An evaluation was completed in 2017 and will be used to update the plan in 2018 for the next five years.

\section{Aruba}

Aruba did not have a formal biodiversity strategy and action plan in 2015, nor is such a plan to be expected soon.

\section{Curaçao}

Curaçao did not have a formal biodiversity strategy and action plan in 2015 , nor is such a plan to be expected soon.

\section{Sint Maarten}

There is a lack of legislation on the conservation of Sint Maarten's biodiversity. A Nature Policy Plan is currently in draft form and includes measures to tackle nature conservation and biodiversity.

\section{Dutch contribution to the achievement of Aichi Targets 17 at a global level}

The Natural Capital Agenda focuses, both nationally and internationally, on the conservation and sustainable use of biodiversity. The focus of ecosystem services protection lies on the implementation and management of natural capital and sustainable production and consumption, mostly outside the Netherlands. Dutch development policy focuses on fair and sustainable growth and prosperity from which everyone benefits. The core of the policy is stated in the document A World to Gain: A New Agenda for Aid, Trade and Investment. ${ }^{209}$ The main goals of the agenda are:

- eliminating extreme poverty within a single generation (getting to zero);

- promoting sustainable and inclusive growth throughout the world;

- success for Dutch companies abroad.

\section{Target 18 \\ Traditional knowledge}

\author{
By 2020, the traditional knowledge, innovations and \\ practices of indigenous and local communities relevant for \\ the conservation and sustainable use of biodiversity, and \\ their customary use of biological resources, are respected, \\ subject to national legislation and relevant international \\ obligations, and fully integrated and reflected in the \\ implementation of the Convention, with the full and \\ effective participation of indigenous and local communi- \\ ties, at all relevant levels.
}

\section{Why this target is important?}

Traditional knowledge contributes to both the conservation and the sustainable use of biological diversity. This target aims to ensure that traditional knowledge and customary sustainable use is respected, protected and encouraged, with the effective participation of indigenous and local communities and reflected in the implementation of the Convention. Given the cross-cutting nature of this target, actions taken to fulfil it will contribute to several of the other Aichi Biodiversity Targets ${ }^{210}$.

\section{Summary of progress towards the target}

Based on the current lack of specific policy in this thematic field and the still rather strong focus on Dutch development cooperation and trade policies, it remains questionable to what extent the Netherlands has contributed to respecting traditional knowledge. Progress towards Aichi Targets 18 in all overseas territories in the Caribbean is assessed as 'not applicable'. The Caribbean Netherlands, Aruba, Curaçao and Sint Maarten lack local or traditional communities as defined by the CBD.

\section{Dutch contribution to the achievement of Aichi Targets 18}

The Netherlands has no indigenous peoples or local communities as defined by the CBD within its borders. It can, however, substantially affect indigenous and local communities beyond its borders through international cooperation, foreign policy and policies on sustainable trade. Specific policy on indigenous peoples dates back to

210 Global Biodiversity Outlook A mid-term assessment of progress towards the implementation of the Strategic Plan for Biodiversity 2011-2020 


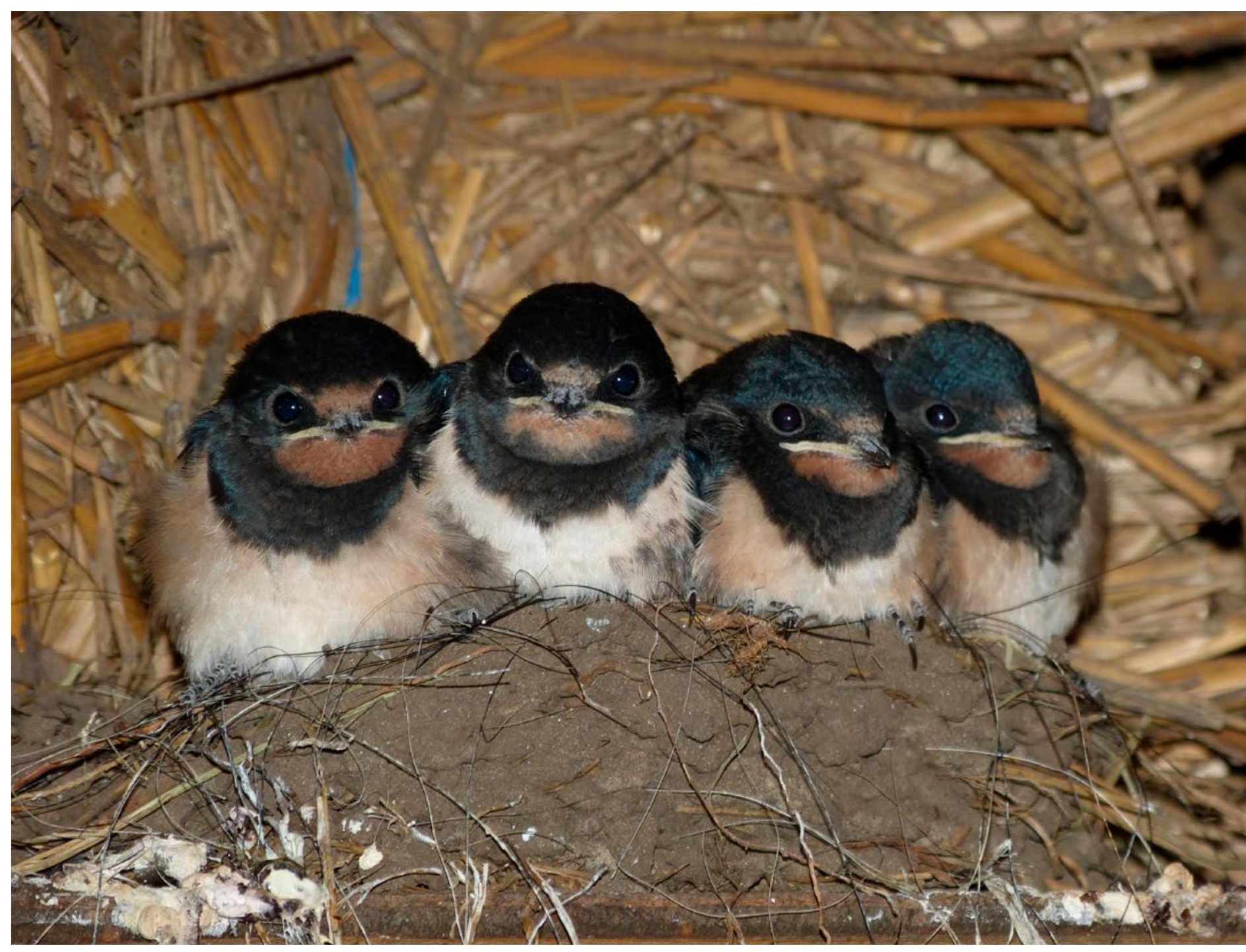

1993 and has not been reviewed since. The Netherlands ratified the Indigenous and Tribal Peoples Convention (ILO Convention 169) in 1998 and voted in favour of the adoption of the UN Declaration on the Rights of Indigenous Peoples (UNDRIP) in 2007, but no specific policies have been developed to support its implementation. The Netherlands Centre for Indigenous Peoples (NCIV) was an NGO that supported the promotion and protection of the rights of indigenous peoples worldwide since 1969, but is no longer active. Other Dutch NGOs, such as Both ENDS, take action for people elsewhere in the world.

Traditional knowledge used in relation to genetic resources is part of the Nagoya Protocol (see Aichi Targets 16). 


\section{Target 19}

Sharing information and knowledge

By 2020, knowledge, the science base and technologies relating to biodiversity, its values, functioning, status and trends, and the consequences of its loss, are improved, widely shared and transferred, and applied.

\section{Why is this target important?}

Biodiversity-related information is vital for identifying threats to biodiversity, determining priorities for conservation and sustainable use, and enabling targeted and cost-effective action. Given this, progress towards this target can contribute to the attainment of the other Aichi Biodiversity Targets. This target is a general commitment to increase the amount and quality of biodiversity-relevant information and technologies available, to make better use of these in decision making, and to share them as widely as possible ${ }^{211}$.

\section{Summary of progress towards the target}

The substance of Aichi Targets 19 is very well developed in the Netherlands and can be considered to have been achieved. Progress towards Aichi Targets 19 in the Caribbean Netherlands and Curaçao is assessed as 'progress towards target but at an insufficient rate'. Progress in Aruba and Sint Maarten is assessed as 'no significant change'.

\section{Dutch contribution to the achievement of Aichi Targets 19}

The Netherlands has a long history in environmental research and biodiversity monitoring. We present the some important platforms for sharing knowledge and information below.

The Knowledge Network for Restoration and Management of Nature in the Netherlands (OBN) is an independent and innovative platform in which management, policy and science work together on nature restoration and conservation management. OBN develops and disseminates knowledge on the restoration and management of nature and is an important partner for everyone involved in

211 Global Biodiversity Outlook A mid-term assessment of progress towards the implementation of the Strategic Plan for Biodiversity 2011-2020 forest, nature and landscape management. This knowledge is made publicly available on a website. ${ }^{212}$

The Netherlands Environmental Assessment Agency (PBL), in cooperation with scientific institutes and NGOs, periodically reports on the status and trends in nature, biodiversity and other environmental issues in the Netherlands. This is a statutory requirement under the Nature Conservation Act. Dutch nature policy is significantly influenced by the content of these reports and the information is widely available. The Dutch language website ${ }^{213}$ includes hundreds of indicators on nature and the environment. The most important indicators, like those needed for the CBD report, are regularly updated. Several indicators are used in national assessments (Balans van de Leefomgeving, Lerende Evaluatie Natuurpact).

One of the actions of the Natural Capital Agenda is the development of the digital Atlas of Natural Capital in the Netherlands. The Atlas of Natural Capital (ANK) is an initiative of the Dutch Ministry of Infrastructure and the Environment and was produced in association with knowledge institutes Deltares, Wageningen Environmental Research, Wageningen Economic Research and RIVM. The Atlas supports the development of information tools for policy and society to treat our natural capital sustainably and to find appropriate solutions, especially for the long term. It provides information about natural capital and ecosystem services, related concepts and inspirational examples. Maps contain information that can be used when taking decisions that affect the human environment at site level. Businesses can use the information to make their operations more sustainable and in their reporting on corporate social responsibility. The ecosystem services and stocks were defined in accordance with the European Union's CICES classification (Common International Classification of Ecosystem Services). The classification was developed to provide an internationally harmonised nomenclature, enabling ecosystem services to be mapped Europe-wide. This is an initial embodiment of the EU Biodiversity Strategy. The Atlas ${ }^{214}$ is a work in progress.

There is a central Dutch web portal on biological diversity. ${ }^{215}$ The objective is to provide a maximum amount of

212 https://www.natuurkennis.nl/

213 www.clo.nl

214 http://www.atlasnatuurlijkkapitaal.nl/home

215 www.biodiversiteit.nl 


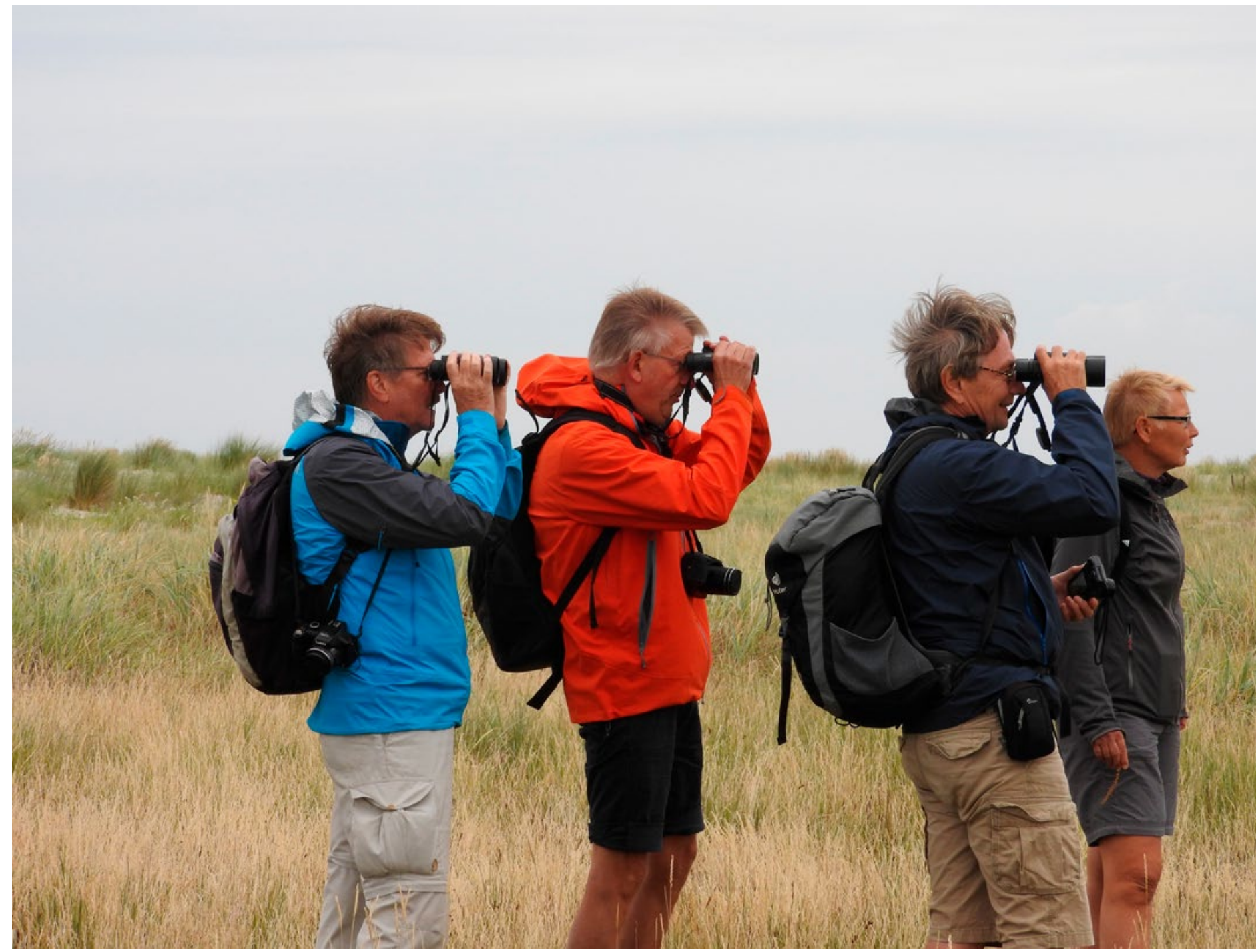

information on biodiversity and biodiversity policy relating to the Netherlands. This portal also forms the Dutch implementation of the Clearing-House Mechanism of the CBD.

National reports of international conventions are published on a website ${ }^{216}$ and news items on nature and biodiversity are also published on a website. ${ }^{217}$

\section{Caribbean contribution to the achievement of Aichi Targets 19}

The Caribbean Netherlands have much higher biodiversity values than the Netherlands, but the monitoring effort is much less intensive. The availability and quality of data is generally insufficient for trend analysis. Only about $10 \%$ of the data are regarded sufficient (see Figure 47) and most of these are from Bonaire and concern species such as seagrasses, Caribbean flamingos, sea turtles and the yellow-shouldered Amazon parrot.

216 www. natuurgegevens. $\mathrm{nl}$

217 https://www.naturetoday.com/intl/en/home
Availability and quality of biodiversity data in the Caribbean Netherlands

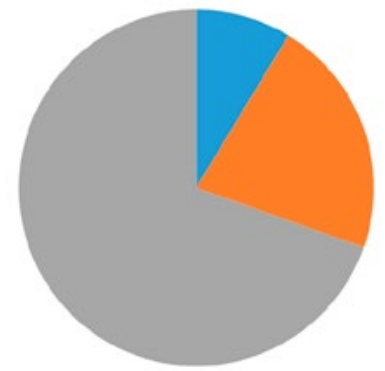

- Sufficient Insufficient $\mathbf{m}$ Poor

Figure 47. Assessment of the availability and quality of data in the Caribbean Netherlands (Debrot et al., 2018)

Research and monitoring was one of the strategic goals in the Caribbean Netherlands Nature Policy Plan 2013-2017. Since the Caribbean islands became special municipalities of the Netherlands on 10 October 2010 many initiatives have been taken. The Ministry of Economic Affairs therefore commissioned the development of the Dutch 
Caribbean Biodiversity Database for Aruba, Bonaire, Curaçao, Saba, Saint Eustatius and Saint Maarten (www.dcbd.nl), which was developed and is managed by Wageningen University and Research (Wageningen UR) in the Netherlands. It was established to guarantee longterm data availability and access, support conservation management and facilitate treaties and convention reporting requirements.

In 2012, the Dutch Ministry of Education, Culture and Science allocated EUR 2.5 million for the establishment of a multidisciplinary knowledge centre in the Caribbean Netherlands, the Caribbean Netherlands Science Institute (CNSI). It is the starting point for research and monitoring in the region and plays an educational role for the local community. The Netherlands Organisation for Scientific Research (NWO) commissioned the Royal Netherlands Institute for Sea Research (NIOZ) to set up this centre, which is located on Saint Eustatius and was opened in 2013. The Ministry of Education, Culture and Science allocated an additional EUR 10 million to launch a research programme covering the Caribbean as a whole. The research programme and the knowledge centre focus on earth and life sciences, complemented by topics from the humanities and social sciences. In 2018 NWO decided to continue its support for the CNSI for another five years and prolong its Caribbean research programme.

The Dutch government provides funding to the Dutch Caribbean Nature Alliance (DCNA) to produce the monthly publication BioNews, which contains information about biodiversity research, monitoring and conservation projects in the Caribbean Netherlands, but also on Aruba, Curaçao and Sint Maarten because DCNA is active there as well. It provides regular updates on science and nature projects as well as overviews of ongoing research and monitoring efforts, long-term projects, recent reports and publications. Bionews is freely available on the internet and is actively distributed to park management and other conservation organisations, island government officials and national government policymakers, students and researchers, the international conservation community and any other interested people.

\section{Aruba}

Very little scientific research currently takes place on Aruba and access to information is rather limited. However, the Dutch Caribbean Biodiversity Database provides access to most of the available studies and data on biodiversity and the DCNA regularly shares information and knowledge through its newsletter BioNews.

\section{Curaçao}

The Carmabi Foundation has been the engine for knowledge generation on Curaçao for more than 50 years. Thousands of scientific studies have been published and are available. The Dutch Caribbean Biodiversity Database provides access to most of the available studies and data on biodiversity. The DCNA regularly shares information and knowledge through its newsletter BioNews.

\section{Sint Maarten}

Recent years have seen a major growth in biological research and publications, particularly from EPIC, a local NGO. The Nature Foundation is also active in generating knowledge and participating in joint science endeavours. The Dutch Caribbean Biodiversity Database provides access to most of the available studies and data on biodiversity. The DCNA regularly shares information and knowledge through its newsletter BioNews. 


\section{Target 20 \\ Mobilising resources from \\ all sources}

\section{By 2020, at the latest, the mobilisation of financial resources for effectively implementing the Strategic Plan for Biodiversity 2011-2020 from all sources, and in accordance with the consolidated and agreed process in the Strategy for Resource Mobilisation, should increase substantially from the current levels. This target will be subject to changes contingent to resources needs assess- ments to be developed and reported by Parties.}

\section{Why is this target important?}

The overall objective of this target is to increase the resources available to implement the Strategic Plan for Biodiversity. The fulfilment of this target will have implications for the feasibility of achieving the other 19 targets contained in the Strategic Plan ${ }^{218}$.

\section{Summary of progress towards the target}

Financial resources from several sources are substantially increasing which is in line with the goals of Aichi Targets 20. The net cost and financing of nature and landscape has not increased, and the biodiversity-related official development assistance decreased substantially. The international target of doubling biodiversity-related funding flows to developing countries by 2015 and maintaining them until 2020 has not been reached. The Netherlands is moving away from this target. On the other hand, market shares of raw materials with sustainable labels and consumer spending on sustainable food has increased substantially (section IV-6 and Aichi Targets 4). Progress towards Aichi Targets 20 in the Caribbean Netherlands is assessed as 'progress towards target but at an insufficient rate'. Progress in Aruba, Curaçao and Sint Maarten is assessed as 'no significant change'.

\section{Dutch contribution to the achievement of Aichi Targets 20}

In Decision XII/3, the Conference of the Parties adopted a financial reporting framework to provide information related to the global financial targets under Aichi Biodiversity Target 20. The Netherlands has submitted the

218 Global Biodiversity Outlook A mid-term assessment of progress towards the implementation of the Strategic Plan for Biodiversity 2011-2020 document 'Reporting on baseline and progress towards $2015^{\prime}$ in the online Financial Reporting Framework. ${ }^{219}$ The biodiversity-related official development assistance (ODA) in 2015 was EUR 51 million. This is less than half the baseline (EUR 106 million), the average biodiversity-related ODA for the years 2006-2010. The coefficient used for resource flows indirectly related to biodiversity is $40 \%$ (The Netherlands, Financial Reporting Framework: Reporting on baseline and progress towards 2015). The annual financial support provided to domestic biodiversity-related activities in the Netherlands reported is EUR 1,455 million in 2015. This amount is below average (EUR 1,685 million) for the years 2007-2015.

\section{Financing of nature conservation}

In order to halt biodiversity loss, the Dutch provinces acquire land for habitat creation to enlarge and defragment the currently small and isolated ecosystems and habitats. The government subsidises conservation management in natural and agricultural areas. Nature conservation organisations and, to a lesser extent, the agricultural sector and several other parties also cover part of the costs of nature and landscape conservation. Other financial sources for nature organisations include donations and a lottery. Net annual cost for nature and landscape conservation has decreased by one fifth to EUR 830 million compared with the peak year 2009 (when it exceeded EUR 1 billion). Net cost equals gross cost minus revenues. Government finances $56 \%$ of these costs (Figure 48).

\section{Green investments}

Efforts to broaden funding sources and increase financing focus especially on the development, wider implementation and acceptance of Innovative Financing Mechanisms (IFMs) and the mobilisation and use of private funding sources. The Green Projects Scheme, which has been in force since 1 April 2016, is a joint arrangement between the Ministry of Infrastructure and the Environment (now Infrastructure and Water Management) and the Ministry of Finance to stimulate sustainable and innovative construction projects. The government gives tax benefits to 'green' savers and investors. Banks and other financial institutions accredited as green institutions can offer loans at lower interest rates to companies to fund green projects. Banks with designated green funds are obliged to invest at least $70 \%$ of those savings in projects approved under the

219 https://chm.cbd.int/pdf/documents/resourceMobilisation/206306/1 


\section{Net cost and financing of nature and landscape}

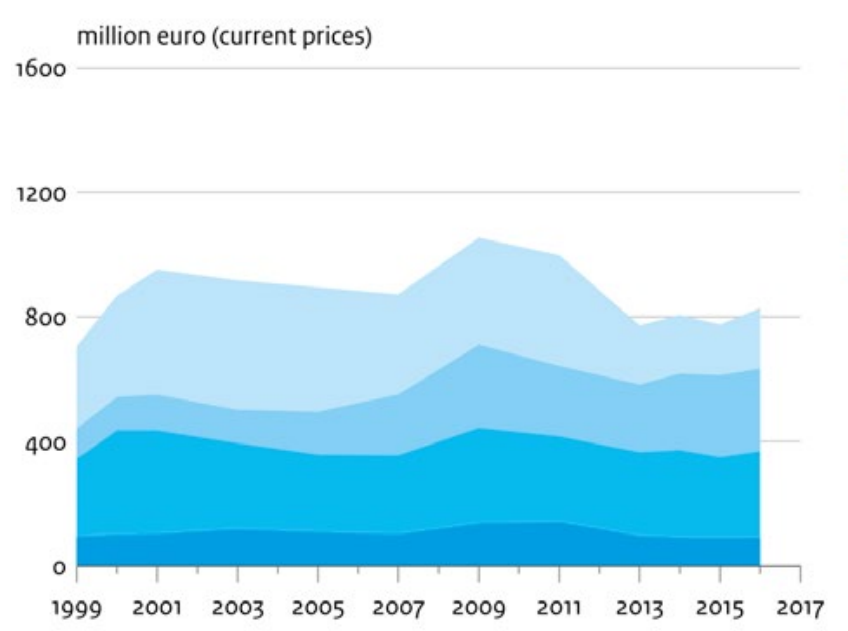

Central government

Local government

Nature conservation

organisations

Private forestry, agriculture, mineral extraction, industry, public utilities

Bron: CBS

CBS/oct18

www.clo.nl/en051908

Figure 48. Net cost and financing of nature and landscape conservation has remained stable on average

Green Projects Scheme. They are permitted to provide such loans for projects that enhance the environment and nature. Only companies holding a Green Declaration may borrow money from this Green Fund at a lower interest rate. These have to be requested by the bank from the Netherlands Enterprise Agency (RVO). The green banks and green funds finance approximately EUR 800 million annually in sustainable projects through the Green Projects Scheme 220 .

\section{Caribbean contribution to the achievement of Aichi Targets 20}

It remains a challenge to provide sustainable and regular funding to cover the operating costs of the organisations managing the marine and terrestrial protected areas on the six Caribbean islands concerned. To support this important work the DCNA set up a trust fund in 2006 and a trust fund bank account was opened at the Rabobank in the Netherlands. The capital is locked in for a defined period and cannot be used to solve short-term funding needs. Revenues from the fund are reinvested (not withdrawn from the fund), and will be until 2016, when a review will take place. A Trust Fund Committee was created by DCNA and provides coordination, leadership and decision-making power throughout this process. The Dutch Ministry of the Interior contributed EUR 750,000

220 https://www.rvo.nl/subsidies-regelingen/regeling-groenprojecten annually (until 2016). DCNA also became a beneficiary of the Dutch Postcode Lottery in February 2009. From each annual donation of EUR 500,000 from the lottery, EUR 200,000 is deposited straight into DCNA's trust fund account.

For the implementation of the NPP-2017 the former Ministry of Economic Affairs earmarked EUR 7.5 million for nature conservation projects on the islands to be implemented over a period of four years, specifically to catch up on outstanding or overdue management measures. Projects will address coral reef conservation, in particular through reduction of erosion, the sustainable use of nature, including better access, and improving the synergy between nature, land use (agriculture) and tourism.

In addition, EUR 600,000 is available annually for implementation of the NPP-2017, plus EUR 500,000 for research, monitoring and reporting on biodiversity. The islands receive EUR 800,000 per year for conservation management, to be used at their own discretion. However, a recalculation of the costs of conservation management in 2015 showed that this amount needed to be increased substantially, in particular for the smallest islands, but the funding was not adjusted accordingly. Revenues from park entrance fees are invested in conservation management, but on the very small islands of Saba and Sint Eustatius these are far too small to cover the costs. Budgets from 
other local sources are unfortunately hardly available on the islands. Though the challenges ahead are far larger than can be covered by current budgets, financial resources have increased substantially. All things considered, much progress has been made towards Aichi Targets 20, although a substantial gap still needs to be filled.

\section{Aruba}

The island does not have a formal biodiversity strategy and action plan and funding has not increased. Arikok National Park does receive significant funding from the government for staff costs and entry fees provide additional revenue.

Providing sustainable and regular funding to cover the operating costs of the organisations managing the marine and terrestrial protected areas in the Dutch Caribbean has proven to be a challenge as a substantial amount of funding is in the form of one-time project subsidies, limited ad hoc financial assistance from local government authorities and fluctuating revenues from tourism. These uncertainties made it virtually impossible for park management organisations to draft long-term plans, create systematic protected area management structures (including the recruitment and retention of qualified personnel from the local community and elsewhere), and even threatened the very survival of some organisations. In 2006 a trust fund was created by the DCNA. The capital is locked in for a defined period and cannot be used to solve short-term funding needs. Revenues from the fund are reinvested. A Trust Fund Committee was created by DCNA and provides coordination, leadership and decision-making power throughout this process. Until 2016 the Dutch Ministry of the Interior contributed EUR 750,000 annually. DCNA became a beneficiary of the Dutch Postcode Lottery in February 2009. From each annual donation of EUR 500,000 from the lottery, EUR 200,000 is deposited straight into DCNA's trust fund account.

\section{Curaçao}

The government of Curaçao has traditionally been the best of all islands in terms of providing structural (although very limited) funding for conservation management, science and conservation education (almost all through Carmabi). Since 10 October 2010, however, structural funding has declined and become less certain, while the need for funding has increased. At the UN Ocean Conference in June 2017, the Curaçao government made two voluntary commitments for the further development of marine research, involving an investment of about USD 5 million over three years. It also committed to codifying a sustainable ocean policy by the end of 2018 . In 2016, a Cooperation Agreement on further improving the conditions for conducting marine biological research in Curaçao was signed by the government of Curaçao, the Curaçao Marine Research Center (CMRC) and CARMABI. Funding has been made available to improve the research infrastructure at CARMABI and the CMRC. This project should be completed by the end of 2019. As in Aruba, it has proven challenging to obtain sustainable and regular funding to cover the operating costs of the organisations managing the marine and terrestrial protected areas in Curaçao.

\section{Sint Maarten}

The Nature Foundation receives financing from the government per the SLA (Service Level Agreement) signed in January 2018. This SLA appoints the Nature Foundation as the scientific and nature authority of the ecosystems on the island. The Nature Foundation also receives revenue from Marine Park user fees. 

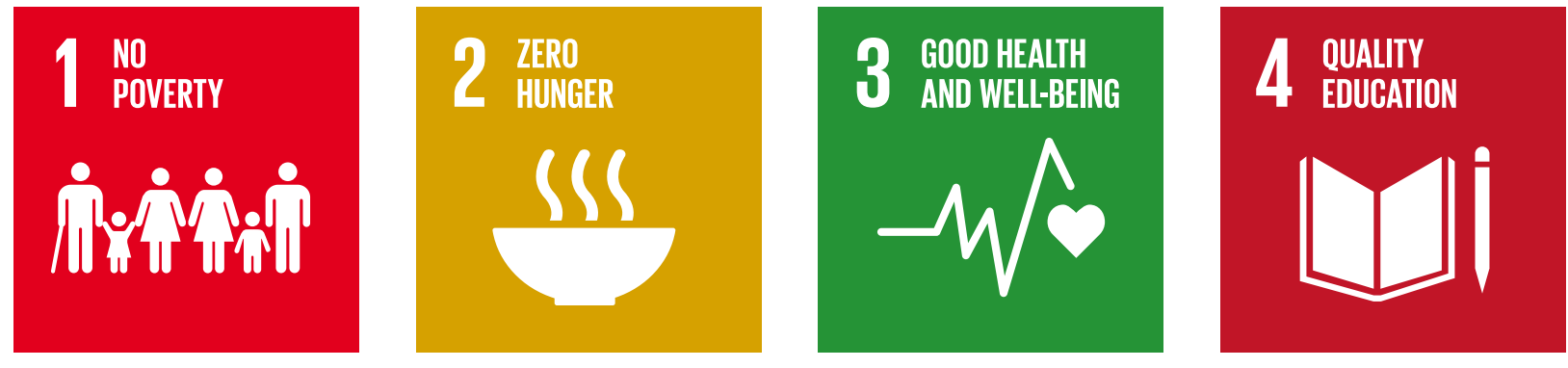

5 GENDER
EQUALITY
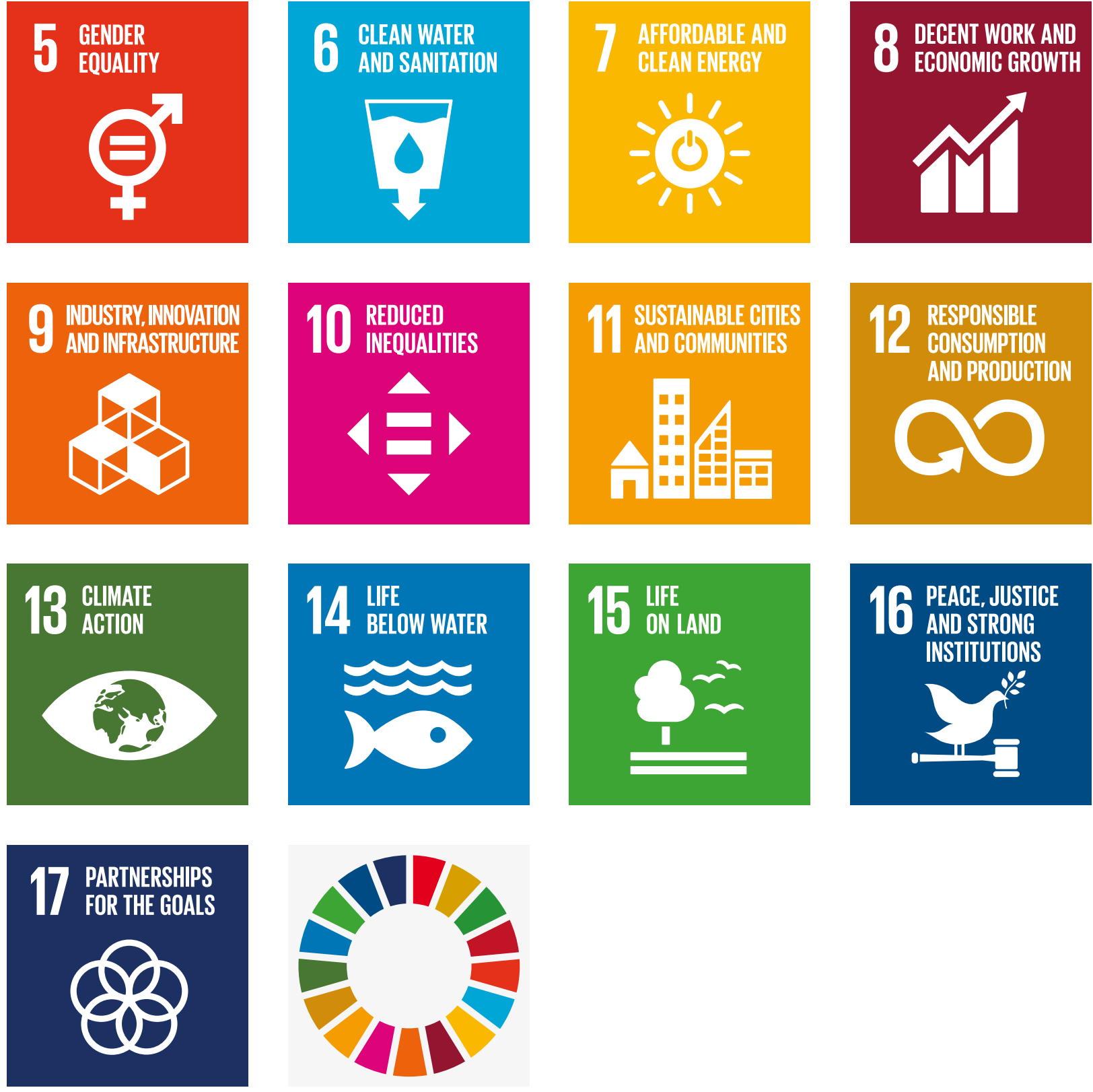

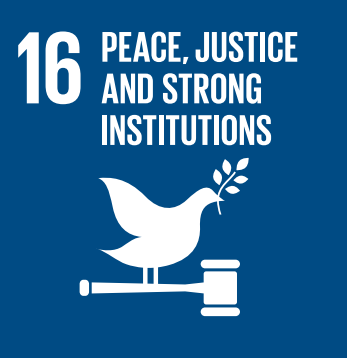




\title{
VI Sustainable Development Goals
}

\author{
Dutch contributions to the attainment of the Aichi Biodiversity Targets that are helping \\ to address the main issues addressed by the 17 Sustainable Development Goals.
}

All Dutch measures taken to achieve the Aichi Biodiversity Targets in the Netherlands automatically contribute directly to SDG 15, 'Protect, restore and promote sustainable use of terrestrial ecosystems, sustainably manage forests, combat desertification, and halt and reverse land degradation and halt biodiversity loss', and SDG 14, 'Conserve and sustainably use the oceans, seas and marine resources for sustainable development'.

Furthermore, Dutch contributions to the attainment of Aichi Biodiversity Target 4, 'Sustainable production and consumption', are helping to address the drivers of biodiversity loss that contribute to the other main issues addressed by the 17 Sustainable Development Goals, such as SDG 12, 'Ensure sustainable consumption and production patterns', and SDG 1, 'End poverty in all its forms everywhere'. The Dutch government has played a facilitating and stimulating role in the transition to sustainable labels by providing financial support to voluntary initiatives, through its procurement policy, and via letters of intent with market parties. Sustainable trade in raw materials can help to prevent people from falling into poverty and can help to lift them out of it by increasing their income and reducing their vulnerability. More information can be found in the report 'Sustainable Development Goals in the Netherlands'.221

Dutch development policy focuses on fair and sustainable growth and prosperity from which everyone benefits. The core of the policy is stated in the document 'A World to Gain: A New Agenda for Aid, Trade and Investment ${ }^{222}$.

The main goals of the agenda are:

- eliminating extreme poverty within a single generation (getting to zero);

- promoting sustainable and inclusive growth throughout the world;

- success for Dutch companies abroad.

221 https://www.pbl.nl/sites/default/files/cms/publicaties/pbl-2016-sustainabledevelopment-in-the-Netherlands_1966.pdf

222 https://www.government.nl/documents/letters/2013/04/05/ global-dividends-a-new-agenda-for-aid-trade-and-investment
Through its aid and trade agenda, the Netherlands is investing in a viable, more stable and safer world in which extreme poverty will be eradicated and inequalities will be reduced. The agenda focuses on themes such as water, security and the rule of law, sexual and reproductive health and rights, food and nutrition security, private sector development, climate, and women's rights and gender equality. These themes are directly related to the SDGs. On a website 223 one can read about how the Dutch development policy is connected to the SDGs.

The Dutch Ministry of Foreign Affairs also supports the Fair Green Global Alliance 224 of six civil society organisations (Both ENDS, SOMO, Milieudefensie and others) which works to alleviate poverty, advocate at various levels for more sustainable consumption and production, and strengthen civil society organisations in tropical and subtropical developing countries.

The Dutch Ministry of Foreign Affairs has made videos to show what actions the Dutch government and partners undertake in developing countries: SDG 2 - the Food challenge 2030; SDG 6 - the Water challenge 2030; and SDG 13 - the Climate challenge 2030. These videos show the results achieved in previous years and the targets for 2030.225

In 2017 the Ministry of Foreign Affairs published a Voluntary National Review of the Kingdom of the Netherlands on the implementation of the Sustainable Development Goals on the occasion of the 2017 United Nations High-Level Political Forum on Sustainable Development. ${ }^{226}$

\footnotetext{
223 https://www.dutchdevelopmentresults.nl/sdg

$224 \mathrm{https}: / /$ fairgreenandglobal.org/

225 SDG 2: https://www.youtube.com/watch?v=qrAIy70voE8 SDG 6: https://www.youtube.com/watch?v=AYYkNLCl88Y SDG 13: https://www.youtube.com/watch?v=QNSINNUmQcU

226 https://sustainabledevelopment.un.org/content/ documents/16109Netherlands.pdf
} 


\section{Country profile}

Biodiversity country profiles provide an overview of information relevant to your country's implementation of the Convention

\section{Biodiversity facts}

The Netherlands is among the most densely populated countries in the world. Agriculture occupies most of the total terrestrial area, followed by forests and dwellings, respectively. Most of the country's terrestrial area is highly productive agricultural land; pristine ecosystems are virtually absent.

The Kingdom of the Netherlands includes six overseas territories: the Caribbean islands of Aruba, Curaçao, Bonaire, Sint Maarten, Saba and Sint Eustatius. Aruba, Curaçao and Sint Maarten are constituent countries within the kingdom, while Bonaire, Saba and Sint Eustatius are special municipalities of the Netherlands, generally referred to as the Caribbean Netherlands. All six islands are part of the Caribbean Islands Biodiversity Hotspot. The ecosystems are very different from the European Netherlands and range from tropical rainforest and caves to mangrove forests and coral reefs. The islands are home to hundreds of endemic and threatened species, many of which probably still need to be discovered. The islands economies are very much dependent on ecosystem services, particularly for tourism and fisheries.

\section{Status and trends of biodiversity, including benefits from biodiversity and ecosystem services and functions}

Since the early 1900 s the average quality of all distinguished types of nature has declined, but since 1990 the Dutch Living Planet Index (LPI) has increased by $7 \%$. The LPI shows the average trend in the population size of the native species of breeding birds, mammals, reptiles, amphibians, butterflies, dragonflies and freshwater fish. The increase is mainly due to an improvement in the quality of fresh water and marsh. The Netherlands also has a relatively large area of wetlands (particularly four large inland waters). It is not yet clear to what extent alien species in the large rivers are invasive and replacing native species. Considerable effort has been invested in safeguarding and restoring existing nature as well as in creating 'new' natural areas.

Among all vertebrates, plants and some major groups of invertebrates, approx. $40 \%$ of the species are, to some extent, threatened with extinction at the national level. Since 2005, the number of threatened species has slowly declined and the threat level has declined slightly.

However, the increase in both the number of threatened species and the average level of threat in 2017 shows that the cautious recovery of recent years is still fragile. The conservation status of $73 \%$ of the protected species and $96 \%$ of the habitat types for which the Netherlands is responsible have recently been assessed as more or less unfavourable in 2012.

Although not all biodiversity has been measured in detail, the state of biodiversity appears to be improving in the North Sea. For example, the stocks of herring and sole are above their biologically safe numbers.

\section{Main pressures on biodiversity and drivers of change (direct and indirect)}

Factors considered to have contributed to the long-term decline (over the 20th century) of populations of animal species include reclamation of semi-natural areas, the drainage of wet areas, use of artificial fertiliser, etc., all to increase agricultural production, as well as expanding urbanisation and infrastructure due to the growth in population size and mobility. Most remaining semi-natural areas were designated as nature reserves to protect them. These nature reserves were too small and fragmented to sustain species populations and they suffered environmental pressures such as from acidification, eutrophication and desiccation, mostly resulting from intensive agricultural land use.

Climate change is causing noticeable distribution shifts in the Netherlands. For instance, birds breed earlier in the breeding season, butterflies start to fly earlier in spring 


\section{Kingdom of the Netherlands}

The Kingdom of the Netherlands consists of four countries: the Netherlands, Aruba, Curaçao and Sint Maarten. The Netherlands consists of a territory in Europe and the islands of Bonaire, Saba and Sint Eustatius in the Caribbean. The position of these islands is similar to that of Dutch municipalities.

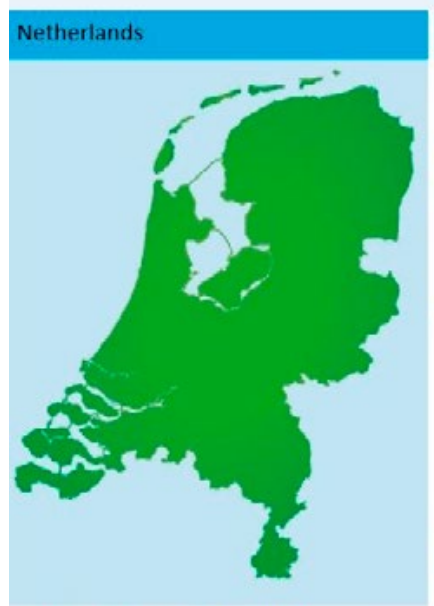

3 special municipalities Bonaire Sint Eustatius Saba

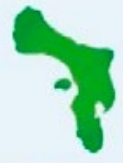

Caribbean part of the Kingdom
1 Aruba
2 Curaçao
4 Sint Maarten
5 Saba

3 Bonaire

6 Sint Eustatius

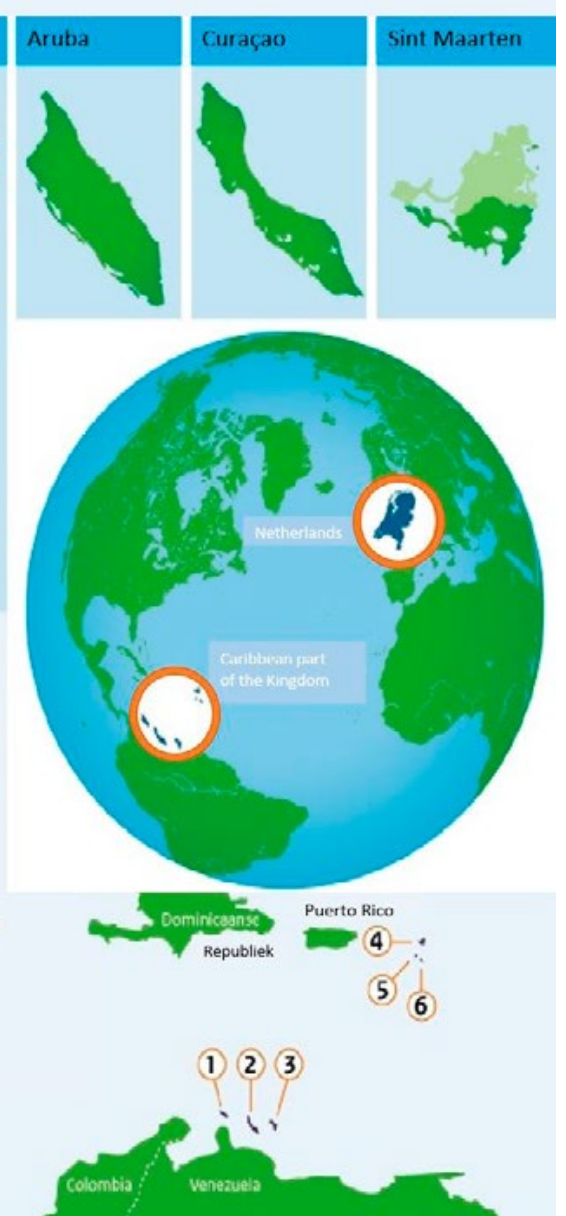

Source: Ministry of BZK

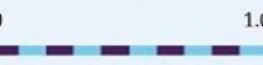

$1.000 \mathrm{~km}$
(1) 2 ( 3 and trends among a selection of species in the Netherlands reveal an increase in species that indicate warmth.

The long-term decline in plant species (including lichens, algae and macrofungi) is attributed to factors such as air pollution, nitrogen deposition, desiccation, habitat destruction, the disappearance of eelgrass beds in the Wadden Sea, increased water temperatures, acidification and eutrophication of waters and decreased forest vitality. Habitat restoration has led to a positive trend in the abundance of Red List species of vascular plants.

Threats to aquatic wildlife include pressures from European fisheries on stocks, which have resulted in a marked decline in large fish catch; the collateral damage caused by fishing gear is also high. Moreover, fishing for most stocks of commercial fish species in the North Sea has not meet the sustainability criteria of the International Council for Exploration of the Sea (ICES) for spawning biomass and fish mortality.

The Caribbean island ecosystems are fragile. Most habitats are small, as are the species populations that depend on them, while the threats are high. Progress towards most Aichi Targets is not on track due to local threats from free-roaming grazing livestock, pollution, invasive species and overfishing, which makes the island habitats less resilient to the major threat of climate change. Actions to 
deal with these local threats, if any, are generally insufficient. This is illustrated by the fact that progress towards five of the Aichi Targets has actually been negative, while no significant change can be observed for $50 \%$ of the targets on some of the islands.

\section{Measures to enhance implementation of the Convention}

\section{Implementation of the NBSAP}

Dutch actions for implementing the Convention are integrated into several national policies and programmes. The Netherlands published its Strategic Action Plan for Biodiversity in 1990, followed by 'Nature for people, people for nature', a policy document for nature, forest and landscape in the 21st century (2000) and in 'Biodiversity works for nature, for people, forever', the biodiversity policy programme of the Netherlands (20082011). Other related policies for addressing specific biodiversity targets were included in various policy documents and white papers, including the Fourth National Environment Policy Plan (2001), 'Sources of our existence: conservation and the sustainable use of genetic diversity' (2002), International Policy Programme on Biodiversity (2002-2006), the policy letter to parliament on agro-biodiversity (2004) and policy paper on invasive alien species (2007). The latest actions are set out in policy documents and legislation, including the Natural Capital Agenda and the national nature vision The Natural Way Forward - Government Vision 2014. The Nature Pact (2013) defines the ambitions for the restoration and management of nature in the Netherlands for the period to the end of 2027.

The first NBSAP for the Caribbean Netherlands was for the period 2013-2017 and the NBSAP for the next period is in draft form. No NBSAPs have been prepared for Aruba, Curaçao or Sint Maarten.

\section{Overall actions taken to contribute to the implementation of the Strategic Plan for Biodiversity 2011-2020}

The six most important overall measures in the Netherlands are:

1 creating new habitat within the national ecological network (NEN) to connect fragmented habitat patches and supporting viable species populations;
2 the Nature Conservation Act, an important instrument for protecting species and habitats;

3 subsidies for conservation management measures important to maintain biodiversity;

4 the Programmatic Approach to Nitrogen (PAN) policy instrument;

5 stimulating sustainable use of natural capital and mainstreaming the use of nature for the benefit of society and the economy;

6 utilising the self-organising ability of society by stimulating, facilitating and financially supporting green initiatives.

The policy for the NEN is to create a sound national network of natural areas, including expanded ecological corridors, by 2027. Several of these areas are designated under the EU Birds and Habitats Directives. The economic values of these areas, including the ecosystem services they provide, are being taken into account. The NEN, in combination with management measures and a substantial decline in environmental pressures, has slowed down the rate of biodiversity loss in the Netherlands.

The EU common fisheries policy has led to more sustainable use of fish stocks and all the most important fish stocks are within safe biological limits. Dutch policy promotes fisheries that minimise collateral damage caused by fishing gear.

The implementation of environmental policy has made progress towards reducing nitrogen emission and deposition to improve environmental conditions and steps have been made to incorporate this policy into other sectors, including agriculture, transportation and industry. However, nitrogen levels are still too high. Some of the reasons for this include high agricultural productivity (including from dairy farms). This often limits the feasibility of conceivable measures because of the considerable social and economic impacts the measure would have. Overall, the reduction of nitrogen emission and deposition still presents challenges for the country. The Programmatic Approach to Nitrogen seeks to limit nitrogen pollution from intensive livestock farming and can be considered to be the most important strategy for making the necessary improvements in environmental conditions for biodiversity restoration. The programme combines restoration measures to improve habitat quality with nitrogen emission measures. Other environmental and spatial planning legislation is also important in this respect. 


\section{Support mechanisms for national implementation (legislation, funding, capacity building, coordination, mainstreaming, etc.)}

The main objective of Dutch development cooperation is to assist poverty reduction and economic development, acknowledging that environment and biodiversity are integral to poverty reduction. A number of measures have also been taken through support funds and coordinated by the Dutch NGOs Hivos and Oxfam-Novib. The Netherlands has also contributed to various international and national organisations working with local communities. These programmes often include support to local communities to strengthen their rights and facilitate participation in decision making.

Through the EU Forest Law and Enforcement, Governance and Trade (FLEGT) Action Plan (2008), a sustainable trade initiative is promoting collaboration among businesses, NGOs and government to create sustainable production and trade chains for soy, timber, tea, cocoa, natural stone, tourism, cotton and aquaculture. Support has been provided for innovative mechanisms to integrate biodiversity concerns into the areas of economy and finance. The intention is to create a demand and supply mechanism for environmental goods and services and related economic instruments, thus integrating biodiversity into the economic system. Further, current biodiversity policy addresses the advice of the Delta Commission to combine nature conservation and water management efforts to increase capacity to adapt to climate change.

\section{Mechanisms for monitoring and reviewing implementation}

There is a big difference between monitoring efforts in the Netherlands and in the Caribbean part of the Kingdom. In the Netherlands, monitoring systems for evaluating and reporting on biodiversity are well established. For the Caribbean islands, on the other hand, long-term monitoring data are generally lacking and monitoring systems similar to those in the Netherlands have not been established. 


\section{Justification}

Biodiversity indicators and information were collected by M.E. Sanders and R.J.H.G. Henkens, both scientific specialists from Wageningen Environmental Research and D.M.E. Slijkerman, specialist from Wageningen Marine Research. This study was supervised by Astrid Hilgers of the Ministry of Agriculture, Nature and Food Quality.

The team consulted several other specialists including specialists from the Ministry of Agriculture, Nature and Food Quality, Netherlands Environmental Assessment Agency ( $P B L)$, the Provincial Governments and the Caribbean islands.

We would like to thank Derek Middleton for the English correction.

The authors wish to thank everyone for their constructive contribution to this report. 


\section{Appendix 1}

\section{Main measures and the national and Aichi Targets they contribute to}

\section{Relation main measures and the national targets they contribute to.}

The table below shows the main measures and to which national targets they contribute to.

1 The national ecological network (main measure 1) contributes to the following national targets:

- new habitat creation enlarges protected areas (Target 1, better conservation of habitats);

- a decrease in fragmentation improves sustainable populations (Target 1 , better conservation of species);

- ecosystem restoration and enlargement improves ecosystem services (Target 2 , ecosystem services enhanced).

2 The Nature Conservation Act (main measure 2) contributes to the following national targets:

- it is prohibited to kill species or to disturb or destroy their nests and resting places (Target 1, better conservation of species);

- it is prohibited to perform activities with negative impact on habitats (Target 1, better conservation of habitats);

- trade in invasive alien species on the EU list is prohibited; invasive alien species have to be eradicated or managed when eradication is still possible (Target 5, invasive alien species).
3 Subsidy for conservation management measures (main measure 3 ) contributes to the following national targets:

- conservation management (Target 1 , habitats areas effectively managed);

- agri-environmental management (Target 3, improvement of species affected by agriculture).

4 Programmatic Approach to Nitrogen (main measure 4) contributes to the following national targets:

- a decrease in nitrogen emissions improves environmental conditions (Target 3, sustainable agriculture);

- restoration measures improve effectiveness of management (Target 1 , better conservation of habitats);

- ecosystem restoration improves ecosystem services (Target 2, ecosystem services enhanced).

5 Stimulating sustainable use of natural capital (main measure 5) contributes to the following national targets:

- agreements to stimulate sustainable agriculture and forestry (Target 3) and sustainable trade (Target 6);

- shared knowledge of nature-inclusive economy improves sustainable use of ecosystem services (Target 2, ecosystem services enhanced);

- innovation to stimulate sustainable fisheries (Target 4).
National targets

\begin{tabular}{l|l|l|l|l|l|l|}
\hline Main measure & 1 & 2 & $\mathbf{3}$ & $\mathbf{4}$ & $\mathbf{5}$ & $\mathbf{6}$ \\
\hline 1 National ecological network (NEN) & & & & & & \\
\hline 2 The Nature Conservation Act & & & & & & \\
\hline 3 Subsidies for management measures & & & & & \\
\hline $\begin{array}{l}\text { 4 Programmatic Approach to Nitrogen (PAN) } \\
\text { 5 Stimulating sustainable use of natural } \\
\text { capital }\end{array}$ & & & & & & \\
\hline $\begin{array}{l}6 \text { Utilising the self-organising capacity of } \\
\text { society }\end{array}$ & & & & & & \\
\hline
\end{tabular}

\section{National targets}

1 Better conservation of species and habitats

2 Maintain and enhance ecosystem services

3 Better conservation of species and habitats affected by agriculture and forestry

4 Sustainable fisheries

5 Invasive alien species controled, eradicated, prevented

6 Contribution to avert global biodiversity loss 


\section{Aichi targets}

\begin{tabular}{|c|c|c|c|c|c|c|c|c|c|c|c|c|c|c|c|c|c|c|c|c|}
\hline National target & 1 & 2 & 3 & 4 & 5 & 6 & 7 & 8 & 9 & 10 & 11 & 12 & 13 & 14 & 15 & 16 & 17 & 18 & 19 & 20 \\
\hline \multicolumn{21}{|l|}{1 Better conservation of species and habitats } \\
\hline \multicolumn{21}{|l|}{2 Maintain and enhance ecosystem services } \\
\hline \multicolumn{21}{|c|}{$\begin{array}{l}3 \text { Better conservation of species and habitats affected } \\
\text { by agriculture and forestry }\end{array}$} \\
\hline \multicolumn{21}{|l|}{4 Sustainable fisheries } \\
\hline \multicolumn{21}{|l|}{$\begin{array}{l}5 \text { Invasive alien species controled, eradicated, } \\
\text { prevented }\end{array}$} \\
\hline 6 Contribution to avert global biodiversity loss & & & & & & & & & & & & & & & & & & & & \\
\hline
\end{tabular}

6 Utilising the self-organising capacities of society (main measure 6) contributes to the following national targets:

- raising awareness (part of National Target 1);

- a nature-inclusive economy to improve ecosystem services (Target 2, ESD enhanced);

- agreements to stimulate sustainable agriculture and forestry (Target 3).

\section{The relation between the national targets and the Aichi Targets}

The table above shows the relation between the national targets and the Aichi Targets. The main Aichi Targets is dark green. Other related targets are light green.

\section{Relation main measures and the Aichi Targets they contribute to.}

A measure can contribute to more than one Aichi Targets and more than one measure can be implemented to achieve a target. The table below shows the relation between the main measures and their contribution to the Aichi Targets.

The contributions made by the main measures to the Aichi Targets are described below.
1 Create new habitat within the national ecological network (main measure 1) contributes to many Aichi Targets:

- the NEN is subject to the 'no, unless' protection regime in the National Policy Strategy for Infrastructure and Spatial Planning (SVIR) (Aichi Targets 2, biodiversity in planning);

- new habitat creation in the NEN reduces fragmentation (Aichi Targets 5, habitat loss and fragmentation);

- larger habitats improve environmental conditions (Aichi Targets 8, pollution);

- multiple anthropogenic pressures on vulnerable ecosystems are minimised (Aichi Targets 10, climate change);

- new habitat creation enlarges protected areas (Aichi Targets 11, protected areas);

- a decrease in fragmentation improves sustainable populations (Aichi Targets 12, protected species);

- new habitat creation restores ecosystem services (Aichi Targets 14, ecosystem services restored);

- ecosystem resilience is enhanced, contributing to climate change mitigation and adaptation (Aichi Targets 15 , resilience).

\section{Aichi targets}

\begin{tabular}{|l|l|l|l|l|l|l|l|l|l|l|l|l|l|l|l|l|l|l|l|l|}
\hline Main measure & $\mathbf{1}$ & $\mathbf{2}$ & $\mathbf{3}$ & $\mathbf{4}$ & $\mathbf{5}$ & $\mathbf{6}$ & $\mathbf{7}$ & $\mathbf{8}$ & $\mathbf{9}$ & $\mathbf{1 0}$ & $\mathbf{1 1}$ & $\mathbf{1 2}$ & $\mathbf{1 3}$ & $\mathbf{1 4}$ & $\mathbf{1 5}$ & $\mathbf{1 6}$ & $\mathbf{1 7}$ & $\mathbf{1 8}$ & $\mathbf{1 9}$ & $\mathbf{2 0}$ \\
\hline 1 National ecological network (NEN) & & & & & & & & & & & & & & & & & & \\
\hline 2 The Nature Conservation Act & & & & & & & & & & & & & & & & & \\
\hline 3 Subsidies for management measures & & & & & & & & & & & & \\
\hline 4 Programmatic Approach to Nitrogen (PAN) & & & & & & & & & & & & & & & & & & & & \\
\hline 5 Stimulating sustainable use of natural capital & & & & & & & & & & & & & & & & \\
\hline 6 Utilising the self-organising capacity of society & & & & & & & & & & & & & & \\
\hline
\end{tabular}


2 The Nature Conservation Act (mean measure 2) contributes to the following Aichi Targets:

- it is prohibited to kill species or to disturb or destroy their nests and resting places (Aichi Targets 12, threatened species);

- it is prohibited to perform activities with negative impact on habitats (Aichi Targets 11, protected areas);

- loss of habitat has to be compensated (Aichi Targets 5, habitat loss);

- trade in invasive alien species on the EU list is prohibited; invasive alien species have to be eradicated or managed when eradication is still possible (Aichi Targets 9, invasive alien species);

- trade in protected species and species products is regulated (Cites) (Aichi Targets 12, threatened species).

3 Subsidy for conservation management measures (main measure 3 ) contributes to the following

Aichi Targets:

- conservation management (Aichi Targets 11, protected areas effectively managed);

- sustainable forest management (Aichi Targets 7, sustainable forestry; Aichi Targets 15, carbon stocks);

- agri-environmental management (Aichi Targets 7, sustainable agriculture).

4 The Programmatic Approach to Nitrogen (main measure 4) contributes to the following Aichi Targets:

- sustainable agriculture (Aichi Targets 7, sustainable agriculture);

- a decrease in nitrogen emissions improve environmental conditions (Aichi Targets 8, pollution);

- multiple anthropogenic pressures on vulnerable ecosystems are minimised (Aichi Targets 10, climate change);

- restoration measures improve effectivity of management (Aichi Targets 11, protected areas effectively managed);

- a decrease in pollution improves sustainable populations of species of nutrient poor habitats (Aichi Targets 12, protected species);

- ecosystem restoration improves ecosystem services (Aichi Targets 14, ecosystem services restored).
5 Mainstreaming nature and stimulating sustainable use (main measure 5) contributes to the following Aichi Targets:

- agreements to stimulate sustainable agriculture and forestry (Aichi Targets 7) and sustainable trade (Aichi Targets 4);

- shared knowledge of nature-inclusive economy improves sustainable use of ecosystem services (Aichi Targets 14, ecosystem services restored); - innovation to stimulate sustainable fisheries (Aichi Targets 6).

6 Utilising the self-organising capacities of society (main measure 6) contributes to the following Aichi Targets:

- raising awareness (Aichi Targets 1 );

- conservation of genetic diversity (Aichi Targets 13);

- a nature-inclusive economy to improve ecosystem services (Aichi Targets 14, ecosystem services restored);

- knowledge shared (Aichi Targets 19). 


\section{Appendix 2}

\section{Tools or means used for assessing progress towards national targets}

The level of confidence of the above assessment:

\section{National targets}

\begin{tabular}{l|l|l|l|l|l|l|}
\hline & $\mathbf{1}$ & $\mathbf{2}$ & $\mathbf{3}$ & $\mathbf{4}$ & $\mathbf{5}$ & $\mathbf{6}$ \\
\hline comprehensive evidence & & & & & & \\
\hline partial evidence & & & & & & \\
\hline limited evidence & & & & & & \\
\hline
\end{tabular}

The adequacy of monitoring information to support assessment:

National targets

\begin{tabular}{l|l|l|l|l|l|l|}
\hline & $\mathbf{1}$ & $\mathbf{2}$ & $\mathbf{3}$ & $\mathbf{4}$ & $\mathbf{5}$ & $\mathbf{6}$ \\
\hline adequate monitoring & & & & & & \\
\hline partial monitoring & & & & & & \\
\hline no monitoring system & & & & & & \\
\hline monitoring not needed & & & & & & \\
\hline
\end{tabular}

By 2020, the assessments of species and habitats protected by EU nature law show better conservation or a secure status for $100 \%$ more habitats and $50 \%$ more species (see also Aichi Targets 12)

The latest assessment of the Birds Directive and Habitats Directive is not yet available. The Birds and Habitats Directive assessment was carried out in 2013; a new assessment is planned for 2019. The assessment of the Water Framework Directive was carried out in 2015; a new assessment is planned for 2021. Indicators used in this assessment:

- Conservation status and trends habitats

- Conservation status and trends species

- Red List index per species group

- Living planet index

The tools and means used for these assessments are field monitoring of species, statistical programmes to calculate trends and indices, mapping of vegetation, samples of water quality and expert knowledge to fill in gaps. A large part of the information is based on comprehensive monitoring and indicators whose confidence level is assessed using statistical tests. There are several monitoring systems (with protocols) in place, such as the Ecological Monitoring Network (NEM) and the monitoring of the Water Framework Directive.

The Netherlands has a long history of ecological monitoring. The NEM was set up in 1999 by various government organisations to monitor nature in the Netherlands with the aim of collecting data to meet governmental needs. The NEM monitors the trends of nearly all species groups relevant to nature policy. As such, the NEM can be considered as the backbone of the monitoring of nature in the Netherlands. The NEM mainly commissions private data-collecting organisations (PGOs) to carry out the monitoring and is therefore a well-established example of citizen science. The NEM monitoring protocols are standardised in cooperation with Statistics Netherlands (CBS). Statistics Netherlands is also responsible for data analysis, which greatly improves the statistical reliability of the reported status and trends of species listed in the EU Habitats Directive and Birds Directive in the Netherlands. In addition to the standardised monitoring data, the NEM increasingly uses less standardised data from other sources. The amount of such opportunistic data that is used is increasing rapidly with the availability of easily accessible websites (waarneming.nl \& telmee.nl) and apps on mobile phones. New statistical modelling by Statistics Netherlands makes these data suitable for monitoring purposes.

By 2020, ecosystems and their services are maintained and enhanced by establishing green infrastructure and restoring at least $15 \%$ of degraded ecosystems (see also Aichi Targets 14)

The assessment by the Netherlands Environmental Assessment Agency was made in 2016. The indicators were updated in 2017 and 2018. 
Indicators used in this assessment:

- Red List of bees

- Winter mortality of bees

Progress with projects, such as those in the Room for the River programme, and trends of species such as bees are based on assessments of data collected by field monitoring. Other data on ecosystem services are modelled, mapped or based on expert knowledge. A considerable amount of data has been collected and made available through the Atlas of Natural Capital website: http://www. atlasnatuurlijkkapitaal.nl/en/home.

Despite the current focus on essential ecosystem services in the Netherlands, their analysis and evaluation is still at an early stage and there is no overall monitoring system in place.

By 2020, the conservation of species and habitats depending on or affected by agriculture and forestry, and the provision of their ecosystem services, show measurable improvements (see also Aichi Targets 7)

Date the assessment was carried out: Assessment of forests: 2014, Assessment of agri-environmental schemes: 2016, Other indicators: 2016

Indicators used in this assessment:

- Area with agri-environmental schemes: 83,000 ha agricultural land in 2017

- Area under organic agriculture

- Nitrogen surplus in Dutch agriculture

- Farmland bird index

- Farmland fauna index

- Forest growing stock, increment and fellings

- Dead wood in Dutch forests

- Area forest with FSC: $46 \%$

- Forest bird index

- Forest fauna index

The tools and means used for these assessments are field monitoring of species, statistical programmes to calculate trends and indices, mapping of vegetation, measures of nitrogen concentration, models to map nitrogen deposition and expert knowledge to fill in gaps. Much of the information is based on monitoring, models for nitrogen deposition and indicators whose confidence level is assessed using statistical tests. The NEM is used to monitor the species that depend on agriculture and forestry. Nitrogen deposition is measured and modelled.

The NEM can be considered as the backbone of the monitoring of nature in the Netherlands. The NEM mainly commissions PGOs to carry out the monitoring and is therefore a well-established example of citizen science. The NEM monitoring protocols are standardised in cooperation with Statistics Netherlands (CBS). Statistics Netherlands is also responsible for data analysis, which greatly improves the statistical reliability of the reported indicators.

The Dutch National Institute for Public Health and the Environment (RIVM) publishes annual charts showing airborne concentrations of substances in the Netherlands, including nitrogen. The maps are based on a combination of model calculations and measurements and are intended to give a large-scale picture of air quality and deposition in the Netherlands.

The areas under organic agriculture were compiled on the basis of the Agricultural Census by Statistics Netherlands. The Agricultural Census is an integral survey of all Dutch farms and horticultural and other agricultural businesses with an economic size above a threshold value of EUR 3,000 Standard Yield.

By 2015, fishing is sustainable. By 2020, fish stocks are healthy and European seas healthier. Fishing has no significant adverse impacts on species and ecosystems (see also Aichi Targets 6)

Date the assessment was carried out: ICES fish stocks: 2018, Other indicators: 2015-2016, Marine Strategy (part 1): 2018

Indicators used in this assessment:

- Fish stock (herring, cod, sole and plaice) in the North Sea

- Trend in eggs of shark and ray in the North Sea

- Trend of benthos in the North Sea

- Trend of fish in the North Sea

- Sustainable fish techniques

- OSPAR indicators Marine Strategy

The tools and means used for these assessments are field monitoring of species, statistical programmes to calculate trends and indices, and expert knowledge to fill in gaps. 
Much of the information is based on monitoring, models and indicators whose confidence level is assessed using statistical tests.

In the Netherlands an appropriate monitoring programme was designed to comply with the requirements of the MSFD (Wijnhoven et al., 2013; Troost et al., 2013). From 2014, all marine monitoring, including for the CFP, Nature 2000 and MSFD purposes, is programmed in the Marine Strategy for the Dutch part of the North Sea, part 2, the MSFD monitoring programme. This programme follows the structure of the MSFD according to the 11 descriptors. Per descriptor a description is given of: the environmental targets, the associated indicators, the research needs per indicator, the research strategy, the functional measurement needs, the monitoring strategy and the measurement plan. The government also invests in the development of joint indicators, well-tuned monitoring programmes and coordinated implementation within OSPAR and the International Council for the Exploration of the Sea (ICES). Within OSPAR the Joint Assessment and Monitoring Programme (JAMP) is the guiding principle for these coordinated actions. Based on JAMP, the OSPAR contracting parties made an Intermediate Assessment in 2017 using the data provided by the monitoring programme of the joint indicators.

Fish stocks are estimated from the results of research by ICES. The ICES website provides guides in the Series of ICES Survey Protocols (SISP), with descriptions of the protocols and procedures used in the ecological and fisheries inventories coordinated by ICES. The average trend of all native species of sharks and rays was calculated using beach observations and catches of research vessels. Fishing data are derived from the International Bottom Trawl Survey (IBTS) and the Beam Trawl survey (BTS). Both are coordinated by ICES. The data were downloaded from the DATRAS database of ICES.

The MSFD Monitoring Plan follows the existing Habitats Directive and Water Framework Directive Monitoring Programmes wherever possible for reasons of cost efficiency and consistency. Any outstanding monitoring demands can be met using the extensive benthos measurement network of the Dutch MWTL water quality monitoring programme, supplemented with information from the WOt (Statutory Research Tasks unit at Wageningen University and Research) for fisheries (shellfish surveys section) and from supplementary area monitoring. The benthos data (above indicator) are derived from the MWTL programme for soil fauna conducted by Rijkswaterstaat in the North Sea. This consists of more than 100 measuring points spread over the Dutch part of the North Sea, of which 84 are outside the coastal zone. A sample was taken from the seabed at each measurement point each year and the number of specimens per species in the sample counted.

\section{By 2020, invasive alien species are identified, priority species controlled or eradicated, and pathways managed to prevent new invasive species from disrupting European biodiversity (see also Aichi Targets 9)}

Date the assessment was carried out:

The Union list of invasive alien species and the indicators are updated regularly.

The indicators were assessed in 2015-2016

Indicators used in this assessment:

- Number of invasive, potentially invasive and other alien species in the Netherlands

- Number of alien species in terrestrial, freshwater and marine ecosystems in the Netherlands

- Dispersion of alien plant species

- Alien species groups

- Pathways of introduction

- Number of eradications

The tools and means used for these assessments are field monitoring of species, statistical programmes to calculate trends and indices, and expert knowledge to fill in gaps. Much of the information is based on monitoring, models and indicators whose confidence level is assessed using statistical tests.

The information on alien species is collected by Dutch specialists in flora and fauna, including those from the species organisations. The information is brought together in the Dutch Species Register (http://www.nederlandsesoorten. $\mathrm{nl}$ ). The data used for this assessment were exported on 12 October 2017 (Selection species 2, 2a, 2b and $2 \mathrm{c}$ excl. 2d). 
By 2020, the EU has stepped up its contribution to avert global biodiversity loss (see also

Aichi Targets 4)

Indicators were updated in 2015 and 2016 Indicators used in this assessment:

- Environmental pressure due to Dutch consumption

- Market share of organic food (produced nationally and internally)

- Raw biotic resources with a sustainable label in consumption and industrial use

The tools and means used for these assessments are administrative information on the number sustainable labels used in production and consumption, and expert assessment. Information is collected by renowned institutes. The Netherlands Environmental Assessment Agency (PBL) collects all market shares of sustainable labels from different organisations. Wageningen University and Research (WUR) collects revenue figures from different organisations as input for the Sustainable Food Monitor.

Monitoring related to this target is partial because the impact of sustainable trade and consumption on biodiversity is unknown. 


\section{Appendix 3 \\ Description of obstacles and scientific and technical needs related to the measures taken}

There are many obstacles and scientific and technical needs related to the measures taken. Below we describe a selection of important obstacles. This selection is part of the national report.

Measure 1: A major obstacle is the difficulty of acquiring the final areas to be converted to nature conservation for the realisation of the national ecological network (NEN) because not all the landowners concerned are willing to cooperate $^{227}$. Furthermore, the NEN will not be large enough to secure the status of all the Habitats and Birds Directives species in the Netherlands. To achieve the targets of these directives, new suitable habitat will also have to be created outside the NEN.

Measure 2: The expected effects of mitigation and compensation measures for species protection are mostly based on expert knowledge rather than scientific evidence $^{228}$. Monitoring is only required in a few specific situations. There are initiatives to change this situation for specific species. For bats, for example, there is a website and online database where volunteers and professionals can collect, manage and share data and information on bats present in bat boxes ${ }^{229}$. Installation of bat boxes is a popular mitigation measure where the suitability of bat resting places has deteriorated or where they have been destroyed.

An important consideration in the protection of Natura 2000 areas is the possibility that activities that do not lead to significant negative effects separately, do so together, in combination. Dose-effect relationships can take various forms through different ecological feedback mechanisms and either strengthen or weaken each other. A tool for determining such cumulative effects is the permit for activities with adverse effects on conservation objectives. However, not all activities and all dose-effect relationships are always known when assessing cumulative effects.

227 https://www.pbl.nl/sites/default/files/cms/publicaties/pbl-2017-lerendeevaluatie-van-het-natuurpact-1769.pdf

228 http://library.wur.nl/WebQuery/wurpubs/fulltext/365958

229 http://www.vleermuiskasten.nl/
Oversight and enforcement are difficult and many municipalities have indicated that they lack the necessary capacity and expertise ${ }^{230}$. Very few applications are made for exemptions (Nature Conservation Act) for flora and fauna, while many more are expected. Compared to the number of activities that can potentially have an adverse effect on protected species, the number of exemptions is low ${ }^{231}$.

Measure 3: An important problem is that several necessary ecological measures are largely incompatible with farmland management that is geared to high productivity. For example, relatively high water tables, herb rich grasslands and a later grassland mowing dates are important measures for meadow birds, but lower productivity levels on approx. $30 \%$ of the area if they are to be effective. Such measures depend on the motivation and commitment of the farmer.

Measure 4: The uncertainty in the average nitrogen deposition on the Netherlands (GDN maps) calculated with the OPS model is estimated at around $30 \% 232$. The uncertainty in local deposition is significantly higher at $70 \%$ (range: $-50 \%$ to $+100 \%$ ). Moreover, there is a difference between the trends in calculated ammonia emissions and the trends in measured ammonia concentrations in the air. The differences have been investigated and corrected. Systematic errors can be eliminated by focusing on a reduction in nitrogen deposition (trend) when permitting new development. AERIUS ${ }^{233}$, the software that calculates nitrogen emissions and deposition, makes use of available source data at the highest possible level of detail and scale, in particular for emission sources that are close to the Natura 2000 sites. AERIUS

230 http://www.natuurindegemeente.nl/magazine/artikelen/september-2014/ kunnen-gemeenten-de-nieuwe-taak-uit-de-wet-natuurbescherming-aan/

231 https://themasites.pbl.nl/balansvandeleefomgeving/jaargang-2014/natuur/ natuurwetgeving-en-soortbescherming

232 Velders et al. (2016). Grootschalige concentratie- en depositiekaarten Nederland Rapportage 2016. RIVM Rapport 2016-0068. Rijksinstituut voor Volksgezondheid en Milieu, Bilthoven. https://www.rivm.nl/bibliotheek/ rapporten/2016-0068.pdf

233 AERIUS: www.aerius.nl 
uses more detailed information than in the GDN maps, making the information more specific in the immediate vicinity of these sites.

In the PAN areas, only restoration measures may be used that have been thoroughly examined by a large number of scientists and also positively assessed by the international review committee, and their implementation and effects must be properly monitored. The interim evaluation of $\mathrm{PAN}^{234}$ concluded that there are risks that measures may not be implemented in a timely fashion because it is difficult to anticipate or account for setbacks. Hydrological measures and new habitat creation are comprehensive measures because they depend on the cooperation of surrounding landowners.

Measures 5 and 6: The measures for stimulating sustainable use of natural capital and for utilising the self-organising capacities of society result in many local and international actions on different levels. The effectiveness and impact of measures such as these on biodiversity are difficult to assess. 


\section{Published documents in the Technical reports series of the Statutory Research Tasks Unit for Nature \& the Environment from 2018 onwards.}

WOt-technical reports are available from the secretary's office, T 0317485471 ; E info.wnm@wur.nl Reports can also be downloaded from www.wur.nl/wotnatuurenmilieu.

113 Arets, E.J.M.M., J.W.H van der Kolk, G.M. Hengeveld, J.P. Lesschen, H. Kramer, P.J. Kuikman \& M.J. Schelhaas (2018). Greenhouse gas reporting for the LULUCF sector in the Netherlands. Methodological background, update 2018

114 Bos-Groenendijk, G.I. en C.A.M. van Swaay (2018). Standaard Data Formulieren Natura 2000-gebieden; Aanvullingen vanwege wijzigingen in Natura 2000-aanwijzingsbes/uiten

115 Vonk, J. , S.M. van der Sluis, A. Bannink, C. van Bruggen, C.M. Groenestein, J.F.M. Huijsmans, J.W.H. van der Kolk, L.A. Lagerwerf, H.H. Luesink, S.V. Oude Voshaar \& G.L. Velthof (2018.) Methodology for estimating emissions from agriculture in the Netherlands - update 2018. Calculations of $\mathrm{CH} 4, \mathrm{NH} 3$, N2O, NOx, PM10, PM2.5 and CO2 with the National Emission Model for Agriculture (NEMA)

116 IJsseldijk, L.L., M.J.L. Kik, \& A. Gröne (2018). Postmortaal onderzoek van bruinvissen (Phocoena phocoena) uit Nederlandse wateren, 2017. Biologische gegevens, gezondheidsstatus en doodsoorzaken.

117 Mattijssen, T.J.M. \& I.J. Terluin (2018). Ecologische citizen science; een weg naar grotere maatschappelijke betrokkenheid bij de natuur?

118 Aalbers, C.B.E.M., D. A. Kamphorst \& F. Langers (2018). Bedrijfs- en burgerinitiatieven in stedelijke natuur. Hun succesfactoren en knelpunten en hoe de lokale overheid ze kan helpen slagen.

119 Bruggen, C. van, A. Bannink, C.M. Groenestein, J.F.M. Huijsmans, L.A. Lagerwerf, H.H. Luesink, S.M. van der Sluis, G.L. Velthof \& J. Vonk (2018). Emissies naar lucht uit de landbouw in 2016. Berekeningen met het model NEMA

120 Sanders, M.E., F. Langers, R.J.H.G. Henkens, J.L.M. Donders, R.I. van Dam, T.J.M. Mattijssen \& A.E. Buijs (2018). Maatschappelijke initiatieven voor natuur en biodiversiteit; Een schets van de reikwijdte en ecologische effecten en potenties van maatschappelijke initiatieven voor natuur in feiten en cijfers

121 Farjon, J.M.J., A.L. Gerritsen, J.L.M. Donders, F. Langers \& W. Nieuwenhuizen (2018). Condities voor natuurinclusief handelen. Analyse van vier praktijken van natuurinclusief ondernemen

122 Gerritsen, A.L., D.A. Kamphorst \& W. Nieuwenhuizen (2018). Instrumenten voor maatschappelijke betrokkenheid. Overzicht en analyse van vier cases

123 Vullings, L.A.E., A.E. Buijs, J.L.M. Donders, D.A. Kamphorst, H. Kramer \& S. de Vries (2018). Monitoring van groene burgerinitiatieven; Analyse van de resultaten van een pilot en nulmeting in vier gemeenten

124 Boonstra, F.G., Th.C.P. Melman, W. Nieuwenhuizen \& A. Gerritsen (2018). Aanpak evaluatie stelselvernieuwing agrarisch natuurbeheer; Uitgangspunten en opties voor een beleidsevaluatie
125 Vullings, L.A.E., A.E. Buijs, J.L.M. Donders \& D.A. Kamphorst (2018). Monitoring van groene burgerinitiatieven; Methodiek, indicatoren en ervaring met pilot en nulmeting.

126 Beltman, W.H.J., M.M.S. ter Horst, P.I. Adriaanse \& A. de Jong (2018). Manual for FOCUS_TOXSWA v5.5.3 and for expert use of TOXSWA kernel v3.3; User's Guide version 5

127 Van der Heide, C.M. \& M.M.M. Overbeek (2018). Natuurinclusief handelen en ondernemen. Scopingstudie 'Bedrijven, economie en natuur'

128 Langers, F. (2018). Recreatie in groenblauwe gebieden; Actualisatie van CLO-indicator 1258 (Bezoek aan groenblauwe gebieden) op basis van data van het Continu Vrijetijdsonderzoek uit 2015

129 Glorius, S.T., I.Y.M. Tulp, A. Meijboom, L.J. Bolle and C. Chen (2018). Developments in benthos and fish in gullies in an area closed for human use in the Wadden Sea; 2002-2016

130 Kamphorst, D.A \& T.J.M. Mattijssen (2018). Scopingstudie Vermaatschappelijking van natuur. Een overzicht van onderzoek bij Wageningen Universiteit \& Research voor het Planbureau voor de Leefomgeving en het ministerie van Landbouw, Natuur en Voedselkwaliteit

131 Breman, B.C., T.J.M. Mattijssen \& T.M. Stevens (2018). Natuur 2.0. Het natuurdebat op social media.

132 Vries, S. de \& W. Nieuwenhuizen (2018) HappyHier: hoe gelukkig is men waar?; Gegevensverzameling en bepaling van de invloed van het type grondgebruik, deel II

133 Kistenkas, F.H., W. Nieuwenhuizen, D.A. Kamphorst \& M.E.A. Broekmeyer (2018). Natuur- en landschap in de Omgevingswet.

134 Michels, R, V. Diogo, W.H.G.J. Hennen, L.F. Puister (2018). Instrumentarium Kosten Natuurbeleid 2018 - Status A; IKN versie 3.0

135 Sanders, M.E. (2018). Voortgang realisatie natuurnetwerk. Technische achtergronden bij de digitale Balans van de Leefomgeving 2018

136 Koffijberg K., J.S.M. Cremer, P. de Boer, J. Nienhuis, K. Oosterbeek \& J. Postma (2018). Broedsucces van kustbroedvogels in de Waddenzee in 2017

137 Egmond, F.M. van, S. van der Veeke, M. Knotters, R.L. Koomans, D. Walvoort, J. Limburg (2018). Mapping soil texture with a gamma-ray spectrometer: comparison between UAV and proximal measurements and traditional sampling; Validation study

138 Glorius, S.T., A. Meijboom, J.T. Wal van der, J.S.M. Cremer (2018). Ontwikkeling van enkele droogvallende mosselbanken in de Nederlandse Waddenzee; situatie 2017.

139 Berg, F. van den, A. Tiktak, D.W.G. van Kraalingen, J.G. Groenwold \& J.J.T.I. Boesten (2018). User manual for GeoPEARL version 4.4.4. 
140 Kuiters, A.T., G.A. de Groot, D.R. Lammertsma, H.A.H. Jansman \& J. Bovenschen (2018). Genetische monitoring van de Nederlandse otterpopulatie; Ontwikkeling van populatieomvang en genetische status 2017/2018

141 Müskens G.J.D.M., M.J.J. La Haye, R.J.M. van Kats \& A.T. Kuiters (2018). Ontwikkeling van de hamsterpopulatie in Limburg. Stand van zaken voorjaar 2018

142 Glorius, S.T. (2018). Ontwikkeling van de bodemdiergemeenschap in de geulen van referentiegebied Rottum; Tussenrapportage twaalf jaar na sluiting (najaar 2017).

143 Brouwer, F., F. de Vries en D.J.J. Walvoort (2018). Basisregistratie Ondergrond (BRO); Actualisatie bodemkaart: herkartering van de bodem in Flevoland

144 Knotters, M. en F.M. van Egmond (2018). Selectie van inwinningstechnieken voor bodemdata; Selecteren vanuit de (onderzoeks)vraag

145 Stuyt, L.C.P.M., M. Knotters, D.J.J. Walvoort, F. Brouwer \& H.T.L. Massop (2018). Basisregistratie Ondergrond - Gd-kartering Laag-Nederland 2018; Provincie Flevoland

146 Arets, E.J.M.M., J.W.H van der Kolk, G.M. Hengeveld, J.P. Lesschen, H. Kramer, P.J. Kuikman \& M.J. Schelhaas (2019). Greenhouse gas reporting of the LULUCF sector in the Netherlands. Methodological background, update 2019

147 Bruggen, C. van, A. Bannink, C.M. Groenestein, J.F.M. Huijsmans, H.H. Luesink, L. Lagerwerf, S.M. van der Sluis, G.L. Velthof \& J. Vonk (2019). Emissies naar lucht uit de landbouw in 2018. Berekeningen met het model NEMA.

148 Lagerwerf, L.A., A. Bannink, C. van Bruggen, C.M. Groenestein, J.F.M. Huijsmans, J.W.H. van der Kolk, H.H. Luesink, S.M. van der Sluis, G.L. Velthof \& J. Vonk (2019). Methodology for estimating emissions from agriculture in the Netherlands. Calculations of $\mathrm{CH}_{4}, \mathrm{NH}_{3}, \mathrm{~N}_{2} \mathrm{O}, \mathrm{NO}_{x \prime}$ NMVOC, PM1O, PM2.5 and $\mathrm{CO}_{2}$ with the National Emission Model for Agriculture (NEMA) - update 2019.
149 Bakker, G., M. Heinen, H.P.A. Gooren, W.J.M. de Groot, F.B.T. Assinck \& E.W.J. Hummelink (2019). Hydrofysische gegevens van de bodem in de Basisregistratie Ondergrond (BRO) en het Bodemkundig Informatie Systeem (BIS); Update 2018.

150 IJsseldijk, L.L., M.J.L. Kik, \& A. Gröne (2019). Postmortaal onderzoek van bruinvissen (Phocoena phocoena) uit Nederlandse wateren, 2018. Biologische gegevens, gezondheidsstatus en doodsoorzaken.

151 Daamen, W.P., A.P.P.M. Clerkx \& M.J. Schelhaas (2019). Veldinstructie Zevende Nederlandse Bosinventarisatie (20172021); Versie 2.0.

152 Bikker, P., L.B. Šebek, C. van Bruggen \& O. Oenema (2019). Stikstof- en fosfaatexcretie van gangbaar en biologisch gehouden landbouwhuisdieren. Herziening excretieforfaits Meststoffenwet 2019.

153 Berg, F. van den, H. Baveco \& E.L. Wipfler (2019). User manual for SAFE (Select Application date For Evaluation) to support the use of the GEM scenarios for cultivations in glasshouses; Version 1.1

154 Os, J. van, L.J.J. Jeurissen en H.H. Ellen (2019). Rekenregels pluimvee voor de Landbouwtelling; Verantwoording van het gebruik van het Identificatie- \& Registratiesysteem.

155 Brouwer, F. \& D.J.J. Walvoort (2019). Basisregistratie Ondergrond (BRO) - Actualisatie bodemkaart; Herkartering van de veengebieden in Eemland

156 Sanders, M.E., R.J.H.G. Henkens \& D.M.E. Slijkerman (2019). Convention on Biological Diversity; Sixth National Report of the Kingdom of the Netherlands.

This WOt-technical report was produced in accordance with the Quality Management System of the Statutory Research Tasks Unit for Nature \& the Environment, part of Wageningen University \& Research.

\section{Disclaimer Wot-publicaties}

The 'WOt-technical reports' series presents the findings of research projects implemented for the Statutory Research Tasks Unit for Nature \& the Environment by various centres of expertise.

WOt-technical report 156 presents the findings of a research project commissioned and funded by the Dutch Ministry of Agriculture, Nature and Food Quality (LNV). 



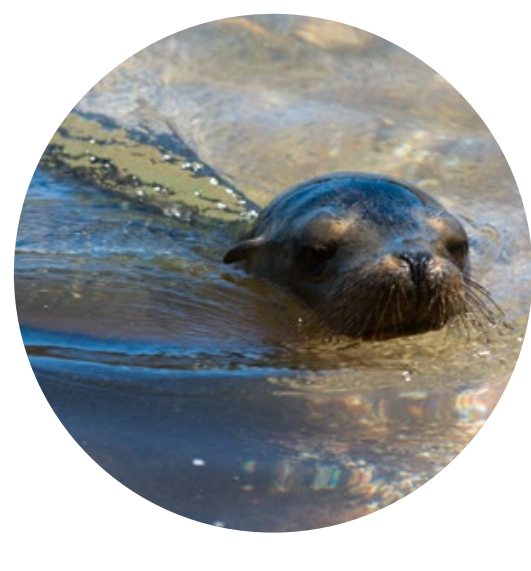

Theme Nature Information Infrastructure

Wettelijke Onderzoekstaken Natuur \& Milieu

P.O. Box 47

6700 AA Wageningen

T (0317) 485471

E info.wnm@wur.nl

ISSN 2352-2739

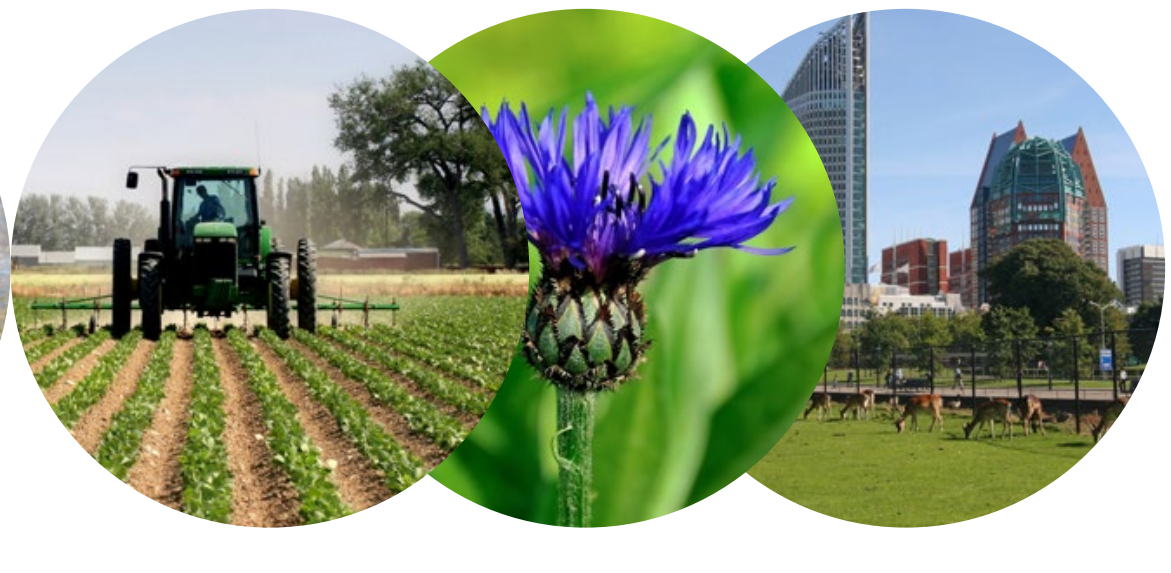

The mission of Wageningen University \& Research is "To explore the potential of nature to improve the quality of life". Under the banner Wageningen University \& Research, Wageningen University and the specialised research institutes of the Wageningen Research Foundation have joined forces in contributing to finding solutions to important questions in the domain of healthy food and living environment. With its roughly 30 branches, 5,000 employees and 10,000 students, Wageningen University \& Research is one of the leading organisations in its domain. The unique Wageningen approach lies in its integrated approach to issues and the collaboration between different disciplines. 